\title{
The Kinetics of the Oxidation-Reduction Reactions of Uranium, Neptunium, Plutonium, and Americium in Aqueous Solutions
}

T. W. Newton

Los Alamos Scientific Laboratory, University of California

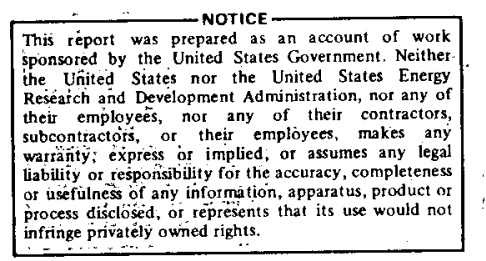

1975 


\section{Library of Congress Cataloging in Publication Data}

Newton, Thomas William, 1923

The kinetics of the oxidation-reduction reactions of uranium, neptunium, plutonium, and americium in aqueous solutions.

(ERDA critical review series)

"TID-26506."

Bibliography: p.

Includes index.

1. Oxidation-reduction reaction. 2. Actinide elements.

3. Solution (Chemistry) I. Title. II. Series: United States.

Energy Research and Development Administration. ERDA critical review series. QD63.09N47

$541^{\prime} .393$

$75-22030$

ISBN 0-87079-020-9

Available as TID-26506 for $\$ 5.45$ (foreign $\$ 7.95$ ) from

National Technical Information Service

U. S. Department of Commerce

Springfield, Virginia 22161

ERDA Distribution Category UC-4

Printed in the United States of America

ERDA Technical Information Center, Oak Ridge, Tennessee

August 1975 


\section{DISCLAIMER}

This report was prepared as an account of work sponsored by an agency of the United States Government. Neither the United States Government nor any agency Thereof, nor any of their employees, makes any warranty, express or implied, or assumes any legal liability or responsibility for the accuracy, completeness, or usefulness of any information, apparatus, product, or process disclosed, or represents that its use would not infringe privately owned rights. Reference herein to any specific commercial product, process, or service by trade name, trademark, manufacturer, or otherwise does not necessarily constitute or imply its endorsement, recommendation, or favoring by the United States Government or any agency thereof. The views and opinions of authors expressed herein do not necessarily state or reflect those of the United States Government or any agency thereof. 


\section{DISCLAIMER}

Portions of this document may be illegible in electronic image products. Images are produced from the best available original document. 


\section{DISCLAIMER}

The enclosed document has not received any secondary reviews by the U.S. Department of Energy's Office of Scientific and Technical Information (OSTI) for public releasability Post 9/11. It is being made available with the understanding that any further distribution, beyond the requesting organization, is the responsibility of the receiving organization/individual. Any distribution outside the DOE community may require additional reviews by the originating site in compliance with Secretary Abraham's May 30, 2002, memorandum titled "Safeguarding Information Pertaining to Weapons of Mass Destruction and Other Sensitive Information." 
From the inception of the Manhattan Project, one of the prerequisites for progress in the development and application of all forms of nuclear energy has been an understanding of the chemistry of the actinide elements. Questions of actinide chemistry enter into every aspect of nuclear energy activities, from prospecting for uranium ores to ultimate disposal of reactor waste products. The expansion of the nuclear energy industry to help meet critical power requirements has reinforced the basic need for detailed knowledge of the properties of the heavy elements. Much of the chemical behavior of uranium, neptunium, plutonium, and americium is governed by the kinetics of their oxidation-reduction reactions.

The Division of Military Application is pleased to have this review published in the Energy Research and Development Administration Critical Review Series.

\section{Ernest Graves}

Major General, U. S. Army

Director, Division of Military Application 


\section{PREFACE}

Since in the near future there will quite probably be an increase in the number of nuclear reactors - particularly breeder reactors, which produce large quantities of plutonium-many more chemists must become concerned with uranium, plutonium, and the other actinide elements. The chemistry of these elements is complicated but is very important in the areas of fuel reprocessing, waste recovery or disposal, and chemical analysis. Since an important part of this chemistry involves ions of the elements in aqueous solution, this review is concerned with the many oxidation states that occur and with the rates of the reactions in which the oxidation states change.

Early work in this field, done during the second World War, helped solve some of the problems of the Manhattan Project. Much of this early work was, of necessity, rather fragmentary, but, since then, an ever increasing amount of careful research has been done on the oxidation-reduction reactions of the actinide elements. Now, after approximately 30 years, it is worthwhile to assemble and discuss the quantitative data available.

This review is addressed not only to the specialist but also to any chemist who would like to know more about the rates of the aqueous oxidation-reduction reactions of the lighter actinide ions. Some typical reactions are discussed in detail to show how we can arrive at, and then interpret, the rate laws and to show glimpses into the underlying mechanisms provided by the rate laws. Although the reader is assumed to have some knowledge of chemical kinetics, a brief discussion of the topics that are particularly important for oxidation-reduction kinetics is included.

In addition to these discussions, all the data available to me in the fall of 1973 are summarized in tables for convenient reference. This summary should be useful to 
those who need to know what has been done on a particular reaction. The omissions indicate some of the areas in which future research is needed.

Since data are now available for many reactions of many types, we might expect to be able to find reactivity patterns that would help in predicting the rates of reactions not yet measured. Some of the generalizations that can be made are discussed, but the reader will note that the patterns are not clear and that detailed predictions must be made with caution. It is tempting to blame this difficulty, at least in part, on the fact that, because water is not a structureless solvent, individual water molecules influence the details of the transition state, or activated complex. Much clearer insight will be required, however, before this idea can be put on a quantitative basis for testing.

Over the past several years I have had helpful discussions with many colleagues. I particularly acknowledge those with Henry Taube and James C. Sullivan. Any errors in reporting, of omission, or in interpretation are my own responsibility, however; and I welcome correspondence on these points. Also, I gratefully acknowledge the careful editorial work done by Dee Jared, U. S. Energy Research and Development Administration, Office of Public Affairs, Technical Information Center, in preparing the original manuscript for publication.

This book is dedicated to William C. Bray, whose teaching and research did so much to lay the foundations for the study of oxidation-reduction kinetics.

\section{T. W. Newton}

Los Alamos Scientific Laboratory University of California 


\section{ABSTRACT}

This is a review with about 250 references. Data for 240 reactions are cataloged and quantitative activation parameters are tabulated for 79 of these. Some empirical correlations are given. Twelve typical reactions are discussed in detail, along with the effects of self-irradiation and ionic strength. 


\section{CONTENTS}

1 Introduction 1

2 Preliminary Considerations 3

2.1 Properties of the Aqueous lons 3

2.2 Mechanism of Aqueous Oxidation-Reduction Reactions 7

2-3 Rate Laws 8

2-4 Medium Effects 11

2-5 Outer-Sphere Reactions 12

2-6 Diffusion-Controlled Reactions 12

3 Kinetics of Some Typical Reactions 14

3-1 The Pu(IV)-V(III) Reaction 14

3-2 The U(IV)-Fe(III) Reaction 16

3-3 The Np(V)-Co(III) Reaction 19

3-4 The $N p(V)-V(I I I)$ Reaction 22

3-5 The $V(I I)-U(V I)$ Reaction 23

3-6 The $\mathrm{Np}(\mathrm{VII})-\mathrm{Hg}(\mathrm{I})_{2}$ Reaction $\quad 25$

3-7 The $\mathrm{Np}(\mathrm{VI})-\mathrm{H}_{2} \mathrm{O}_{2}$ Reaction 27

3-8 The U(IV)-Pu(VI) Reaction 29

3-9 The Pu(VI)-Fe(II) Reaction 32

3-10 The $\mathrm{Cr}(\mathrm{II})-\mathrm{Np}(\mathrm{V})$ Reaction 34

3-11 The U(IV)-CI(III) Reaction 38

3-12 The U(IV)-Cr(VI) Reaction $\quad 40$ 
4 Reactions Among the lons of Uranium, Neptunium, and Plutonium

5 Effects of Self-I rradiation in Plutonium Solutions 55

6 Reactions of Americium lons 58

6-1 Radiolytic Effects 58

6-2 Reaction Rates 60

6-3 The $\mathrm{Am}(\mathrm{V})-\mathrm{H}_{2} \mathrm{O}_{2}$ Reaction 60

6-4 The Am(VI)- $-\mathrm{H}_{2} \mathrm{O}_{2}$ Reaction 61

6-5 Oxidation of $A m(I I I)$ and $A m(V)$ by Peroxydisulfate 61

6-6 Disproportionation of $\mathrm{Am}(\mathrm{V}) \quad 63$

6-7 Reaction Between $A m(V I)$ and $N p(V) \quad 66$

7 Effect of lonic Strength 67

8 Thermodynamic Quantities for the Overall Processes 71 and Activation Processes

9 Empirical Correlations $\quad 81$

9-1 Hydrogen-Ion Dependences $\quad 81$

9-2 Entropies of Activation 84

9-3 Entropies of the Activated Complexes 86

9-4 Heats of Activation 86

9-5 Free Energies of Activation 88

10 Catalog of Reaction Rates 91

11 References $\quad 120$

$\begin{array}{ll}\text { Index } & 128\end{array}$ 


\section{INTRODUCTION}

In the next few years the use of nuclear reactors will increase, and many more chemists will be concerned with problems of analysis, fuel reprocessing, waste disposal, etc. It is the purpose of this review to provide these chemists with a complete survey of one of the important areas in this work. The aqueous ions of the actinide elements uranium, neptunium, plutonium, and americium show as many as five oxidation states with widely varying oxidation potentials; thus oxidation-reduction reactions form a very important part of the chemistry of these elements. A knowledge of the rates of these reactions is required for designing many chemical separation processes and for developing analytical procedures.

Understanding the kinetics of these reactions is aided by the fact that the ions of the elements in the same oxidation states differ only in the numbers of relatively well shielded $\mathrm{f}$ electrons. The ionic radii show the small actinide contraction, which for the +3 and +4 ions decreases by about $3 \%$ from uranium to plutonium. Thus the corresponding ions of the four elements are similar enough to make their reactions of particular interest to chemical kineticists who are trying to understand the various factors that influence the rates of oxidation-reduction reactions.

The history of the discovery and separation of neptunium, plutonium, and americium is discussed, for example, in the book by Katz and Seaborg. ${ }^{1}$ The earlier work on oxidation-reduction reactions is also summarized there. At present a much larger body of kinetics data, almost all of which is summarized in the tables in Chap. 10, is available. Some of these data are only qualitative or semiquantitative, but fairly complete studies, including temperature coefficients, have been made on at least 
79 reactions. These results are summarized in Table 8.1 in terms of $\Delta \mathrm{G}^{*}, \Delta \mathrm{H}^{*}$, and $\Delta S^{*}$ for the net activation processes involved.

No attempt will be made to consider all these reactions in detail; instead some typical examples, arranged roughly in order of increasing complexity, are discussed. Some interesting empirical correlations among the data have been found; these are discussed in Chap. 9.

Before discussing the kinetics of the reactions, we should consider the properties of the aqueous ions and review some of the general aspects of kinetics and mechanisms which are applicable to aqueous oxidation-reduction reactions; this is done in Chap. 2.

The new International System of Units, which is coming into general use in the scientific literature, has been adopted for this review. Thus energy values are given either in joules $(\mathrm{J})$ or kilojoules $(\mathrm{kJ})$, whichever is appropriate. Since the original literature cited used calories or kilocalories, however, values in these units are given in parentheses. Concentrations are given in kilomoles per cubic meter, defined at room temperature, and the usual symbol, $M$, is used. Temperatures are given in degrees Celsius. Seconds are the preferred unit of time, but for some of the less precise work the original units are retained. 


\section{PRELIMINARY CONSIDERATIONS}

It is generally agreed (see Ref. 1) that the corresponding oxidation states of the four elements under consideration differ only in the numbers of $f$ electrons and that the formulas are $\mathrm{An}^{3+}, \mathrm{An}^{4+}, \mathrm{AnO}_{2}^{+}$, and $\mathrm{AnO}_{2}^{2+}$ for the $+3,+4,+5$, and +6 oxidation states. The formulas for the recently discovered +7 oxidation states, particularly in acid solutions, are not known. For the first four oxidation states, the oxidation potentials and their temperature coefficients have been determined or have been estimated. The resulting values of $\mathrm{E}^{0}, \Delta \mathrm{G}, \Delta \mathrm{H}$, and $\Delta \mathrm{S}$ for $1 M \mathrm{HClO}_{4}$ are summarized in Table 2.1. The oxidation of the $\mathrm{An}^{3+}$ hydrated cation to the $\mathrm{An}^{4+}$ hydrated cation is seen to involve widely differing values for the thermodynamic quantities, except those for $\Delta S$, which are quite similar. This similarity is evidence that the structural changes are very similar for the reactions.

The oxidation of the +5 to the +6 state shows similarly varying potentials, but again the $\Delta S$ values are nearly the same. The oxidation of the +4 to the +5 state is more complicated since oxycations are formed from more simply hydrated cations. The $\Delta S$ values for uranium and plutonium are quite similar, but the value for neptunium is about $42 \mathrm{~J} / \mathrm{mol} \cdot \mathrm{K}$ more positive. This might imply structural differences. We should note, however, that, because of the slowness of the reactions 
Table 2.1

THERMODYNAMIC QUANTITIES FOR THE OXIDATION REACTIONS ${ }^{\mathrm{a}}$

\begin{tabular}{|c|c|c|c|c|}
\hline Element & $\begin{array}{c}\mathbf{E}^{0} \\
\mathbf{V}\end{array}$ & $\begin{array}{c}\Delta \mathrm{G} \\
\mathrm{kJ} / \mathrm{mol} \\
(\mathrm{kcal} / \mathrm{mol})\end{array}$ & $\begin{array}{c}\Delta \mathrm{H} \\
\mathrm{kJ} / \mathrm{mol} \\
(\mathrm{kcal} / \mathrm{mol})\end{array}$ & $\begin{array}{c}\Delta \mathrm{S}, \\
\mathrm{J} / \mathrm{mol} \cdot \mathrm{K} \\
(\mathrm{cal} / \mathrm{mol} \cdot \mathrm{deg})\end{array}$ \\
\hline \multicolumn{5}{|c|}{$\mathrm{An}^{3+}+\mathrm{H}^{+}=\mathrm{An}^{4+}+1 / 2 \mathrm{H}_{2}$} \\
\hline $\mathbf{U}$ & $0.631^{b}$ & $-60.9(-14.55)$ & $-99.2\left(-23.7^{\mathrm{C}}\right)$ & $-128\left(-30.5^{\mathrm{d}}\right)$ \\
\hline $\mathrm{Np}$ & $-0.155^{\mathrm{e}}$ & $15.0\left(3.58^{\mathrm{e}}\right)$ & $-23.8\left(-5.7 \pm 0.2^{\mathrm{e}}\right)$ & $-131\left(-31.2 \pm 0.8^{\mathrm{e}}\right)$ \\
\hline $\mathrm{Pu}$ & $-0.9819^{\mathrm{f}}$ & $94.7(22.64)$ & $57.0(13.63 \mathrm{~g})$ & $-126\left(-30.2^{\mathrm{g}}\right)$ \\
\hline $\mathrm{Am}$ & $-2.34 \pm 0.1^{h, i}$ & $-226\left(54 \pm 2.3^{\mathrm{j}}\right)$ & $187\left(44.8 \pm 2.3^{j}\right)$ & $-128\left(-30.7 \pm 0.5^{\mathrm{k}}\right)$ \\
\hline \multicolumn{5}{|c|}{$\mathrm{An}^{4+}+2 \mathrm{H}_{2} \mathrm{O}=\mathrm{AnO}_{2}^{+}+3 \mathrm{H}^{+}+1 / 2 \mathrm{H}_{2}$} \\
\hline U & $-0.605^{l}$ & $58.4\left(13.95^{\mathrm{m}}\right)$ & $125.5\left(30.0^{\mathrm{m}}\right)$ & $226\left(54 \pm 1^{\mathrm{m}}\right)$ \\
\hline $\mathrm{Np}$ & -0.739 & $71.3\left(17.04^{\mathrm{e}}\right)$ & $149\left(35.6 \pm 0.3^{\mathrm{e}}\right)$ & $261\left(62.3 \pm 0.1^{\mathrm{e}}\right)$ \\
\hline $\mathrm{Pu}$ & $-1.1702^{f}$ & $112.9(26.98)$ & $178\left(42.5 \pm 0.6^{n}\right)$ & $218\left(52 \pm 2^{n}\right)$ \\
\hline Am & $-1.31 \pm 0.2^{\mathrm{j}}$ & $130(31 \pm 4)$ & $198\left(47.3 \pm 2.5^{\circ}\right)$ & $230\left(55 \pm 3^{k}\right)$ \\
\hline \multicolumn{5}{|c|}{$\mathrm{AnO}_{2}^{+}+\mathrm{H}^{+}=\mathrm{AnO}_{2}^{2+}+1 / 2 \mathrm{H}_{2}$} \\
\hline $\mathrm{U}$ & $-0.063^{b}$ & $6.1(1.45)$ & $12.1(2.9)$ & $20\left(4.8 \pm 1^{\mathrm{p}}\right)$ \\
\hline $\mathrm{Np}$ & $-1.1373^{\mathrm{e}}$ & $109.7\left(26.23^{\mathrm{e}}\right)$ & $118\left(28.1 \pm 0.2^{\mathrm{e}}\right)$ & $27\left(6.4 \pm 0.6^{\mathrm{e}}\right)$ \\
\hline $\mathrm{Pu}$ & $-0.9164^{\mathrm{f}}$ & $88.4\left(21.13^{f}\right)$ & $92(22.09 \mathrm{q})$ & $13\left(3.2 \pm 2^{9}\right)$ \\
\hline Am & $-1.53 \pm 0.05^{\mathrm{j}, \mathrm{o}, \mathrm{r}}$ & $148\left(35.4 \pm 1.2^{j}\right)$ & $154\left(36.9 \pm 1^{S}\right)$ & $21\left(5 \pm 1^{\mathrm{k}}\right)$ \\
\hline
\end{tabular}

${ }^{\mathrm{a}}$ Values are for $25^{\circ} \mathrm{C}$ and $1 \mathrm{M} \mathrm{HClO}_{4}$.

${ }^{b}$ Ref. 2 .

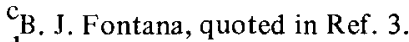

$\mathrm{d}_{\text {Ref. } 3 .}$.

Ref. 4.

Ref. 5 .

gef. 6.

${ }_{\text {h }}$ Ref. 7, based on measurements in $10 \mathrm{M} \mathrm{H}_{3} \mathrm{PO}_{4}$ extrapolated to $1 \mathrm{M} \mathrm{HClO}_{4}$.

$\mathrm{i}_{\mathrm{A}}$ previous estimate, $-2.44 \pm 0.2 \mathrm{~V}$ (Ref. 8), was based on the assumption that $\mathrm{Am}^{3+}$ quantitatively oxidizes water (see Ref. 9).

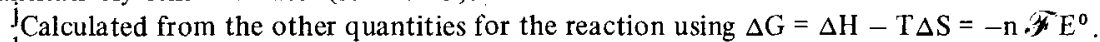

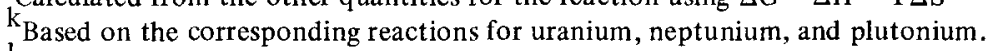

${ }^{\mathrm{l}}$ This would be $-0.573 \mathrm{~V}$ if based on the U(V) disproportionation data (see Ref. 10).

${ }^{m}$ Values for $\mathrm{U}^{4^{+}}+2 \mathrm{H}_{2} \mathrm{O}=\mathrm{UO}_{2}^{2+}+2 \mathrm{H}^{+}+\mathrm{H}_{2}$ (Ref. 3) combined with those for $\mathrm{UO}_{2}^{+}+\mathrm{H}^{+}=\mathrm{UO}_{2}^{2+}+1 / 2 \mathrm{H}_{2}$.

${ }^{n}$ From $\Delta \mathrm{S}$ for $\mathrm{Pu}^{3+}+2 \mathrm{H}_{2} \mathrm{O}=\mathrm{PuO}_{2}^{2+}+\mathrm{H}^{+}+3 / 2 \mathrm{H}_{2}$ (Ref. 6) with the values tor $\mathrm{Pu}^{3+}+\mathrm{H}^{+}=\mathrm{Pu}^{4+}+1 / 2 \mathrm{H}_{2}$ and $\mathrm{PuO}_{2}^{+}+\mathrm{H}^{+}=\mathrm{PuO}_{2}^{2+}+1 / 2 \mathrm{H}_{2}$.

${ }^{\circ}$ From $92.1 \pm 1.0 \mathrm{kcal} / \mathrm{mol}$ for $\mathrm{Am}^{3+}+2 \mathrm{H}_{2} \mathrm{O}=\mathrm{AmO}_{2}^{+}+2 \mathrm{H}^{+}+\mathrm{H}_{2}$ (Ref. 11) and the value above for $\mathrm{Am}^{3+}+\mathrm{H}^{+}=\mathrm{Am}^{4+}+1 / 2 \mathrm{H}_{2}$.

$\mathrm{p}_{\text {From }} \Delta \mathrm{S}$ for $\mathrm{Np}^{3+}+\mathrm{UO}_{2}^{2+}=\mathrm{Np}^{4+}+\mathrm{UO}_{2}^{+}$(Ref. 12) combined with that for $\mathrm{Np}^{3+}+\mathrm{H}^{+}=\mathrm{Np}^{4+}+1 / 2 \mathrm{H}_{2}$.

${ }_{\mathrm{q}}$ Recomputed from the temperature dependence given in Ref. 5 .

${ }^{r}$ In good agreement with $-1.60 \mathrm{~V}$, given in Ref. 13 .

From the 92.1 in note $\mathrm{o}$ and $129.0 \pm 0.3 \mathrm{kcal} / \mathrm{mol}$ for $\mathrm{Am}^{3+}+2 \mathrm{H}_{2} \mathrm{O}=\mathrm{AmO}_{2}^{2+}+\mathrm{H}^{+}+3 / 2 \mathrm{H}_{2}$ (Ref. 11). 
involved, $\Delta S$ is difficult to determine, and most of the difference may be due to experimental error.

$\mathrm{Np}(\mathrm{VII})$ and $\mathrm{Pu}(\mathrm{VII})$ are very powerful oxidizing agents. No quantitative thermodynamic data are available on the ions in this oxidation state in acid solutions. Contrary to an early report, there is as yet no evidence for Am(VII) in aqueous solutions. ${ }^{14}$

The standard entropies of individual aqueous ions are determined from the heats of solution, entropies, and solubilities of appropriate crystalline solids and from the activities of the salts in the resulting solutions. Such measurements have been made for only three of the actinide ions. The results, in calories per mole per degree, are $\mathrm{S}_{\mathrm{OO}}^{2+}{ }_{2}^{+}=-17 \pm 5$ (Ref. 15), $\mathrm{S}_{\mathrm{NpO}_{2}^{2+}}^{0}=-20 \pm 2$ (Ref. 16) and $\mathrm{S}_{\mathrm{Pu}^{3+}=-44.6( \pm 2)}^{0}$ (Ref. 17). From these values, the entropies of the other actinide ions were estimated by using the heat and free-energy values for the $\mathrm{NpO}_{2}^{+}-\mathrm{NpO}_{2}^{2+}$ couple and making corrections for the effects of mass and magnetic degeneracy. ${ }^{16,17}$ These estimates are listed in Table 2.2 .

Table 2.2

STANDARD ENTROPIES OF THE ACTINIDE IONS ${ }^{a}$

\begin{tabular}{|c|c|c|c|c|}
\hline Element & $\mathbf{A n}^{3+}$ & $\mathrm{An}^{4+}$ & $\mathrm{AnO}_{2}^{+}$ & $\mathrm{AnO}_{2}^{2+}$ \\
\hline $\mathrm{U}$ & $-176\left(-42.1_{b}^{b}\right)$ & $-392\left(-93.7^{\mathrm{c}}\right)$ & $-29\left(-7^{\mathrm{d}}\right)$ & $-94\left(-22.5^{\mathrm{d}}+1.1^{\mathrm{e}}\right)$ \\
\hline $\mathrm{Np}$ & $-181\left(-43.3^{b}\right)$ & $-400\left(-95.6^{\mathrm{c}}\right)$ & $-26\left(-6.2^{d}\right)$ & $-84\left(-20 \pm 2^{\mathrm{d}, \mathrm{f}}\right)$ \\
\hline $\mathrm{Pu}$ & $-187\left(-44.6^{\mathrm{b}, \mathrm{f}}\right)$ & $-401\left(-95.9^{c}\right)$ & $-24\left(-5.8^{\mathrm{d}}\right)$ & $-80\left(-19.2^{\mathrm{d}}\right)$ \\
\hline Am & $-204\left(-48.7^{b}\right)$ & & $-24\left(-5.7^{\mathrm{d}}\right)$ & $-79\left(-18.8^{\mathrm{d}}\right)$ \\
\hline
\end{tabular}

\footnotetext{
${ }^{\mathrm{a}}$ Values are for $25^{\circ} \mathrm{C}$ and are given in $\mathrm{J} / \mathrm{mol} \cdot \mathrm{deg}$ and $\mathrm{cal} / \mathrm{mol} \cdot \mathrm{deg}$ (values in parentheses), based on $\mathrm{S}_{\mathrm{H}^{+}}^{+}=0.0$.

${ }^{\mathrm{b}}$ From Ref. 17.

${ }^{c}$ Values are estimated from those in Table 2.1 and are corrected for effect of ionic strength.

$\mathrm{d}_{\text {From Ref. } 16 .}$

$\mathrm{e}_{\mathrm{Based}}$ on the uncertainty in the method of estimating the magnetic contribution.

$\mathrm{f}_{\text {Experimental values. }}$
}

The standard entropies apply to solutions of zero ionic strength; but it is valuable to convert them to unit ionic strength for use with other data, such as those in Table 2.1. The change in ionic entropy on going from zero to unit ionic strength depends on the ionic charge, and we estimate $\dagger$ that the entropies will be more positive at $\mu=1 M$ by about $0,8,23$, and $46 \mathrm{~J} / \mathrm{mol} \cdot \mathrm{K}$ for $\mathrm{AnO}_{2}^{+}, \mathrm{AnO}_{2}^{2+}, \mathrm{An}^{3+}$, and $\mathrm{An}^{4+}$, respectively, based on $\mathrm{S}_{\mathrm{H}^{+}}=0.0$ for $\mu=1.0 \mathrm{M}$.

$\dagger$ These estimates are based on the derivative with respect to temperature of an extended form of the Debye-Hückel equation: $\log \mathrm{K}=\log \mathrm{K}^{0}+\left[\left(\mathrm{A} \Delta \mathrm{z}^{2} \mu^{1 / 2}\right) /\left(1+\mathrm{B} \stackrel{0}{\mathrm{a}} \mu^{1 / 2}\right)\right]+\mathrm{C} \mu$. The results depend somewhat on the values chosen for $a$ and $C$, but essentially the same values were obtained using $\stackrel{\circ}{a}=0.75 \mathrm{~nm}$ and $\mathrm{C}=0$ as with $\stackrel{\circ}{\mathrm{a}}=0.9 \mathrm{~nm}$ and $\mathrm{C}=0.1$. 
These corrections and the $\Delta \mathrm{S}$ values in Table 2.1 were used to give the estimated values for the $\mathrm{An}^{4+}$ ions in Table 2.2. Values for the $\mathrm{AnO}_{2}^{2+}$ ions, found the same way, are $\mathrm{S}_{\mathrm{UO}_{2}^{2+}}^{0}=-99 \mathrm{~J} / \mathrm{mol} \cdot \mathrm{K}, \quad \mathrm{S}_{\mathrm{NpO}_{2}^{2+}}^{0}=-66 \mathrm{~J} / \mathrm{mol} \cdot \mathrm{K}, \quad$ and $\mathrm{S}_{\mathrm{PuO}_{2}^{2+}}^{0}=-123$ $\mathrm{J} / \mathrm{mol} \cdot \mathrm{K}$. Except for $\mathrm{UO}_{2}^{2+}$, these values are not in good agreement with those in Table 2.2 and show that further work needs to be done on the thermodynamics of these actinide ions.

The actinide ions have characteristic, relatively sharp absorption bands that are often used to follow their reactions. The approximate locations and absorptivities of some of these bands are listed in Table 2.3. Detailed spectra may be found in the original references.

Table 2.3

ABSORPTIVITIES ( $\epsilon$ ) AND WAVELENGTHS $(\lambda)$ OF IMPORTANT ABSORPTION BANDS OF SOME ACTINIDE IONS IN AQUEOUS ACID SOLUTIONS

\begin{tabular}{|c|c|c|c|c|c|c|c|c|c|}
\hline \multicolumn{2}{|c|}{ An(III) } & \multicolumn{2}{|c|}{ An(IV) } & \multicolumn{2}{|c|}{$A n(V)$} & \multicolumn{2}{|c|}{ An(VI) } & \multicolumn{2}{|c|}{ An(VII) } \\
\hline $\begin{array}{c}\epsilon, \\
\mathrm{m}^{2} / \mathrm{mol}^{\mathrm{a}}\end{array}$ & $\begin{array}{c}\lambda, \\
\mathrm{nm}\end{array}$ & $\begin{array}{c}\epsilon, \\
\mathrm{m}^{2} / \mathbf{m o l}^{\mathbf{a}}\end{array}$ & $\begin{array}{l}\lambda, \\
\mathrm{nm}\end{array}$ & $\begin{array}{c}\epsilon, \\
\mathrm{m}^{2} / \mathrm{mol}^{\mathrm{a}}\end{array}$ & $\begin{array}{c}\lambda, \\
\mathrm{nm}\end{array}$ & $\begin{array}{c}\epsilon, \\
\mathrm{m}^{2} / \mathrm{mol}^{\mathrm{a}}\end{array}$ & $\begin{array}{c}\lambda, \\
\mathrm{nm}\end{array}$ & $\begin{array}{c}\epsilon, \\
\mathrm{m}^{2} / \mathrm{mol}^{\mathrm{a}}\end{array}$ & $\begin{array}{c}\lambda, \\
\mathrm{nm}\end{array}$ \\
\hline \multicolumn{10}{|c|}{ Uranium } \\
\hline $\begin{array}{r}158.0 \\
17.1 \\
22.2 \\
22.6\end{array}$ & $\begin{array}{l}350^{\mathrm{b}} \\
526^{\mathrm{f}} \\
890^{\mathrm{f}} \\
910^{\mathrm{f}}\end{array}$ & 5.9 & $648^{\mathrm{c}}$ & $\mathrm{d}$ & & 0.76 & $414^{e}$ & & \\
\hline \multicolumn{10}{|c|}{ Neptunium } \\
\hline $\begin{array}{r}229.5 \\
159.3 \\
4.0 \\
4.4\end{array}$ & $\begin{array}{l}233^{\mathrm{e}} \\
267^{\mathrm{e}} \\
580^{\mathrm{g}} \\
786^{\mathrm{g}}\end{array}$ & $\begin{array}{l}12.7 \\
16.2\end{array}$ & $\begin{array}{l}723^{g} \\
960^{g}\end{array}$ & $\begin{array}{r}2.3 \\
39.5\end{array}$ & $\begin{array}{l}617^{g} \\
980^{g}\end{array}$ & 4.5 & $1223^{g}$ & $\begin{array}{l}46.7 \\
43.1\end{array}$ & $\begin{array}{l}360^{h} \\
420^{h}\end{array}$ \\
\hline
\end{tabular}

Plutonium

\begin{tabular}{|c|c|c|c|c|c|c|c|}
\hline 150.0 & $244^{i}$ & 5.65 & $470^{\mathrm{i}}$ & 41.0 & $274^{i}$ & 1.35 & 504 \\
\hline 3.8 & $562^{1}$ & 3.5 & $654^{1}$ & 1.9 & $570^{1}$ & 55.0 & $830^{1}$ \\
\hline 3.7 & $600^{1}$ & & & 2.2 & $1131^{1}$ & & \\
\hline \multicolumn{8}{|c|}{ Americium } \\
\hline 30.0 & $228^{j}$ & & & 4.4 & $514^{\mathrm{j}}$ & 3.0 & $663^{j}$ \\
\hline 40.0 & $503^{j}$ & & & 5.9 & $718^{\mathrm{j}}$ & 8.3 & $996^{\mathrm{j}}$ \\
\hline 6.5 & $812^{l}$ & & & & & & \\
\hline
\end{tabular}

a This unit $\left(\mathrm{m}^{2} / \mathrm{mol}\right)$ is the same as $M^{-1} \mathrm{~mm}^{-1}$.

${ }^{\mathrm{b}}$ Ref. 18.

CRef. 19.

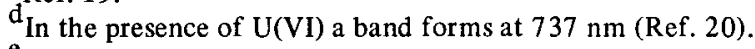

Ref. 21. 
The complexing of the actinide ions by other substances, usually anions, is important for our purposes because the reaction rates of the resulting complexes are usually different from those of the original ions. This also applies to the various hydrolyzed species that form as the $\mathrm{pH}$ of the solutions is increased. Discussions of complex formation and hydrolytic equilibria are beyond the scope of this review; the reader is referred to other sources, e.g., books by Katz and Seaborg, ${ }^{1}$ Cleveland, ${ }^{27}$ and Keller. ${ }^{28}$

In general, however, the tendency to hydrolyze or to form complexes with anions follows the charge density and has the order

$$
\mathrm{An}^{4+}>\mathrm{An}^{3+}>\mathrm{AnO}_{2}^{2+}>\mathrm{AnO}_{2}^{+}
$$

In addition, the $\mathrm{AnO}_{2}^{+}$ions have a charge distribution such that they can form moderately stable complexes with cations such as $\mathrm{Fe}^{3+}$ (Ref. 29), $\mathrm{Cr}^{3^{+}}$(Refs. 30-32), $\mathrm{Rh}^{3+}$ (Ref. 33), and $\mathrm{UO}_{2}^{2+}$ (Refs. 20 and 34).

\section{MECHANISM DF AQUEOUS OXIDATION-REDUCTION REACTIONS}

The most important aspects of any reaction are its stoichiometry and equilibrium, followed by its rate and mechanism. Ideally, stoichiometry and equilibrium, as well as the complex ion and hydrolysis equilibria, are known from thermodynamic data before the reaction rates are measured. But even after the rates are known, the details of the mechanism may still be uncertain. By "mechanism" we mean the sequence of individual steps or elementary reactions occurring as the system goes from reactants to products. For aqueous oxidation-reduction reactions, the various steps may include:

1. Formation of reactive species, such as complex ions, hydrolyzed ions, or radicals.

2. Encounter of two (usually) reactive species; this can also be described as the formation of an outer-sphere complex.

3. Removal of a ligand from one of the reactant species to form an inner-sphere complex in which the reactants share a common ligand.

4. Distortion of the complex so that the electron(s) can transfer under FranckCondon restrictions. These restrictions will not be required if the oxidation-reduction is accomplished by the transfer of a neutral atom or group.

5. Dissociation of the product complex.

6. Separation of the immediate products of reaction.

7. Further reaction of the individual immediate products to give the final products.

We should recognize that not all of these steps are required in every reaction. In fact, determination of the mechanism involves identifying the reactive species and 
determining which steps are involved, whether some steps occur in parallel with others, and which steps are slowest. The mechanism will be called outer sphere if it can be shown or inferred that steps 3 and 5 are not involved. Some of the consequences of this mechanism are discussed in Sec. 2-5. If step 2 is the slowest step, the reaction will be diffusion controlled. Limiting rates for these reactions are given in Sec. 2-6.

\section{$2 \cdot 3$}

\section{RATE LAWS}

We can learn much about the mechanism of a reaction by detecting reaction intermediates, by carefully comparing the data from similar reactions, and by studying the rate law. Although the rate law provides essentially no information about the rapid steps, it is important because it helps to specify the composition of the system at the highest barriers, which are associated with the slowest steps. The rate law is the quantitative function that gives the dependence of the reaction rate on concentrations of the various species in solution. In its most useful form the rate law is made up of individual terms each having the form $\mathrm{k}[\mathrm{A}]^{\mathrm{n}}[\mathrm{B}]^{\mathrm{m}}[\mathrm{C}]^{\mathrm{p}} \ldots$, where $\mathrm{k}$ is a rate constant and $[\mathrm{A}],[\mathrm{B}]$, etc., are the concentrations of the indicated species.

The various steps or elementary reactions in a mechanism involve the crossing of energy barriers. The configuration of the reactants at the top of one of these barriers is called the activated complex or transition state. According to Eyring's absolute reaction-rate theory, ${ }^{35}$ the activated complex can be treated as a special sort of molecule in quasi equilibrium with the reactants for that step. Formation of the activated complex from the reactants is called an activation process. The change in free energy for the process, $\Delta G^{*}$, is called the free energy of activation. The rate of reaction is assumed to be proportional to the concentration of the activated complex, and the rate constant is given by

$$
\mathrm{k}_{\mathrm{i}}=\kappa \frac{\mathrm{k}_{\mathrm{B}} \mathrm{T}}{\mathrm{h}} \mathrm{e}^{-\Delta \mathrm{G}_{\mathrm{i}}^{*} / \mathrm{RT}}=\kappa \frac{\mathrm{k}_{\mathrm{B}} \mathrm{T}}{\mathrm{h}} \mathrm{e}^{\Delta \mathrm{S}_{\mathrm{i}}^{*} / \mathrm{R}} \mathrm{e}^{-\Delta \mathrm{H}_{\mathrm{i}}^{*} / \mathrm{RT}}
$$

$$
\text { where } \begin{aligned}
\kappa & =\text { transmission coefficient } \\
\mathrm{k}_{\dot{\mathrm{B}}} & =\text { Boltzmann constant } \\
\mathrm{h} & =\text { Planck's constant } \\
\mathrm{T} & =\text { absolute temperature } \\
\mathrm{R} & =\text { gas constant } \\
\Delta \mathrm{H}^{*} & =\text { heat of activation } \\
\Delta \mathrm{S}^{*} & =\text { entropy of activation }
\end{aligned}
$$

Thus the rate constant is defined in terms of $\Delta \mathrm{G}^{*}$ for a particular activation process, and the rate law associated with it involves the concentrations and standard states implied by the activation process. Conversely, the numerical values of $\Delta G^{*}, \Delta H^{*}$, and 
$\Delta S^{*}$ may depend on the concentration units employed, the composition of the solution, etc.

For many reactions the barrier for one of the steps is much higher than that for the others; the highest step will be rate determining and the others will be essentially at equilibrium. The rapid equilibria that precede the actual rate-determining step can be added to the activation process for the slow step to give a net activation process, written in terms of the principal species in solution,

$$
\mathrm{mA}+\mathrm{nB}+\mathrm{pC}+\ldots=[\text { activated complex }]^{*}+\mathrm{q} \mathrm{L}+\mathrm{rM}+\ldots
$$

The rate will be proportional to

$$
\frac{[\mathrm{A}]^{\mathrm{m}}[\mathrm{B}]^{\mathrm{n}}[\mathrm{C}]^{\mathrm{p}} \ldots}{[\mathrm{L}]^{\mathrm{q}}[\mathrm{M}]^{\mathrm{r}} \ldots}
$$

where $\mathrm{A}, \mathrm{B}, \mathrm{C}, \ldots$ are initial reactants and $\mathrm{L}, \mathrm{M}, \ldots$ are products of the rapid pre-equilibria. Since the net activation process must formally balance, the composition of the activated complex can be determined from the form of the rate law even though the actual reactant species are unknown. Conversely, the form of the rate law does not identify the actual reactant species.

If two or more barriers are of nearly equal heights, the rate law will be more complicated in that it will have terms similar to those in Eq. 2.3 for each of the barriers. If the barriers are crossed in parallel, the rate law will consist of a sum of terms like those in Eq. 2.3. If the highest barriers are crossed sequentially, the rate law will involve the concentrations of the intermediates involved. If the concentrations of the intermediate(s) are small enough so that the net rates at which their concentrations change are small compared with the overall rate (the steady-state approximation), the rate law can be expressed in terms of the concentrations of the initial reactants.

Although the rate law for a reaction does not give the detailed mechanism, it does give the composition of the activated complexes at the highest barriers, as shown, and the pattern of paths for the reaction. By "pattern of paths," as contrasted with mechanism, we mean the various ways in which reactants can get to products without considering intermediates that are in rapid equilibrium with the initial reactants or final products. If only a single activated complex is kinetically important, only one pattern is possible: Reactants $\rightarrow$ products. If more than one activated complex is involved, the possible patterns of paths are analogous to the possible ways in which electrical resistors can be connected. In this analog the resistors correspond to kinetic barriers (activated complexes), the junctions correspond to intermediates, and the terminals correspond to reactants or products.

For two activated complexes there are two distinguishable patterns; for three activated complexes four patterns are generally distinguishable; for four activated complexes ten patterns are distinguishable; and so on. Figure 2.1 shows the first three of these sets of patterns, classified according to the number of activated complexes 


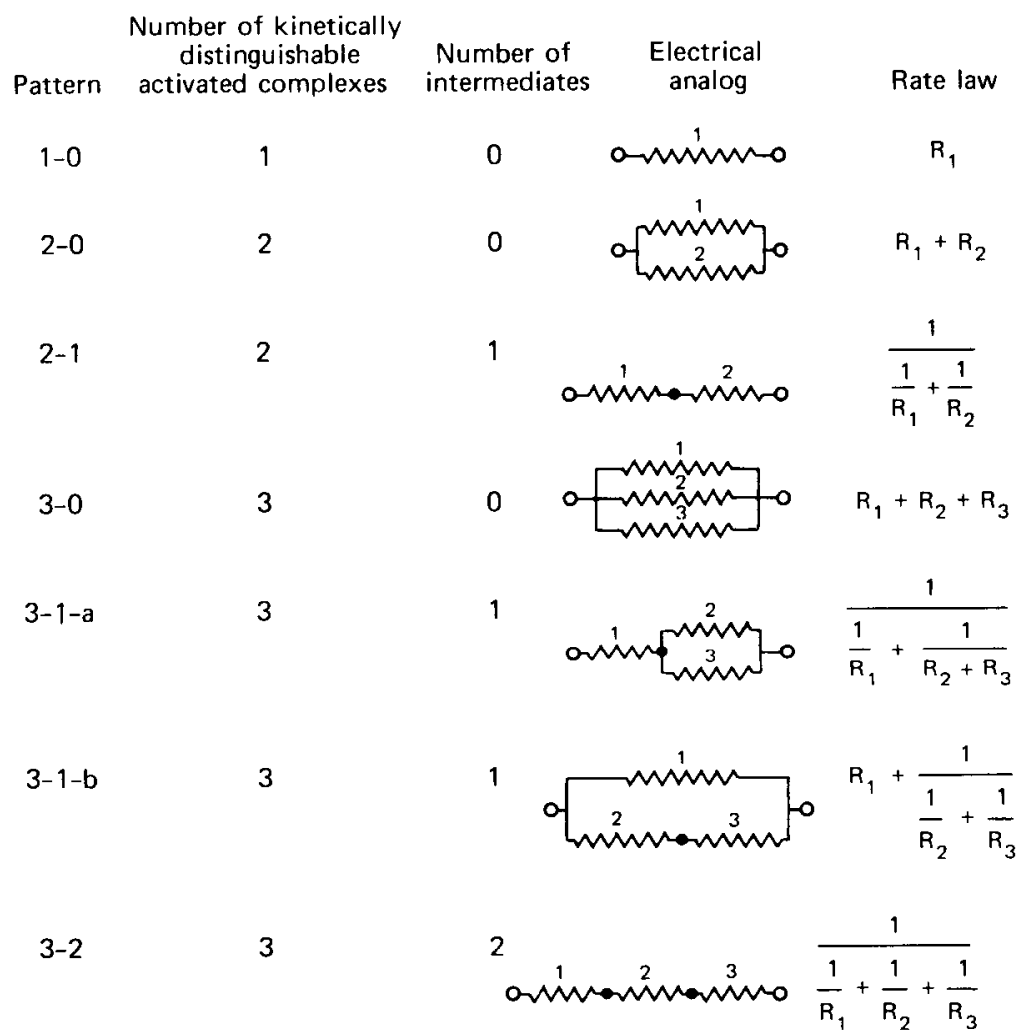

Fig. 2.1 Various patterns of paths. All the $R_{i}$ are of the form $k_{i}[A]^{m_{i}}[B]^{n_{i}}[C]{ }^{p_{i}} \ldots$, where $A$, $\mathrm{B}, \mathrm{C}$, etc., are the initial reactants. (From Lanthanide/Actinide Chemistry, Advances in Chemistry Series, Vol. 71, p. 280, The American Chemical Society, 1967.)

and the number of intermediates involved. Note that none of the patterns are kinetically distinguishable from their mirror images. ${ }^{36}$

We can see from the figure that, in general, the various $\mathrm{R}$ terms must be different functions of $[A],[B],[C]$, etc. For patterns 3-1-a and 3-1-b, $R_{1}$ may have the same form as either $R_{2}$ or $R_{3}$; if this occurs, however, the two patterns cannot be distinguished. An example of this is the $\mathrm{Fe}(\mathrm{II})-\mathrm{Pu}(\mathrm{VI})$ reaction, which is discussed in Sec. 3-9.

An important feature of these electrical analogs is that, when the steady-state approximation is valid, the reciprocals of the indicated resistances are the analogs of $\mathrm{k}[\mathrm{A}]^{\mathrm{m}}[\mathrm{B}]^{\mathrm{n}}[\mathrm{C}]^{\mathrm{p}} \ldots$, where $\mathrm{A}, \mathrm{B}, \mathrm{C}, \ldots$ are the initial reactants and $\mathrm{k}$ is the effective rate constant for the formation of the activated complex directly from the initial reactants, even if intermediates are involved. This means that the overall rate law can be found by combining individual rate terms according to the rules for combining the analogous reciprocal resistances. 
To determine the rate law for a reaction, we must vary the concentrations of the species in solution over as wide a range as possible. Even though the ionic strength is held constant, it is important to consider the possibility that an observed effect on the rate is caused by changes in the activity coefficients of the reactants or activated complex rather than by a distinct step in the mechanism. Usually the species being oxidized and reduced are dilute enough so that changes in their concentrations will not influence the medium significantly. When the effect of a hydrogen ion or a complexing anion, such as chloride or sulfate, is studied, however, large changes in concentration are used. Typically the principal cation will be changed from $\mathrm{H}^{+}$to $\mathrm{Li}^{+}$or $\mathrm{Na}^{+}$, or the principal anion will be changed from $\mathrm{ClO}_{4}^{-}$to $\mathrm{Cl}^{-}$. Effects on the medium due to changes of this sort are often assumed to be negligible, but it is more reasonable to assume that the pertinent activity coefficient ratios are given by an equation like Harned's Rule. ${ }^{37}$ Taking the hydrogen ion as an example, we would get

$$
\mathrm{k}=\mathrm{k}_{0} \mathrm{e}^{\beta\left[\mathrm{H}^{+}\right]}
$$

If the coefficient $\beta$ is small, the exponential can be expanded, and the expression can be rewritten as

$$
\mathrm{k}=\mathrm{k}_{0}\left(1+\beta\left[\mathrm{H}^{+}\right]+\ldots\right) \approx \mathrm{k}_{0}+\mathrm{k}_{0} \beta\left[\mathrm{H}^{+}\right]
$$

If $\beta$ is positive, this expression is indistinguishable from the two-term rate law for parallel paths. If $\beta$ is negative, let $\beta^{\prime}=-\beta$ and

$$
\mathrm{k} \approx \frac{\mathrm{k}_{0}}{1+\beta^{\prime}\left[\mathrm{H}^{+}\right]}=\left\{\frac{1}{\mathrm{k}_{0}}+\frac{1}{\left(\mathrm{k}_{0} / \beta^{\prime}\right)\left[\mathrm{H}^{+}\right]^{-1}}\right\}^{-1}
$$

which is indistinguishable from the rate law for consecutive reactions, pattern 2-1 in Fig. 2.1.

Thus the distinction between an actual step in a mechanism and a medium effect must be based on an estimate of the magnitude of the parameter $\beta$. If the reactant ions are of the same sign as the ion whose concentration is being changed, $\beta$ is expected to be small. ${ }^{38}$ This is supported by the data available. Values of $\beta$ for equilibria among cations are known from measurements of the effect of substituting $\mathrm{Li}^{+}$or $\mathrm{Na}^{+}$for $\mathrm{H}^{+}$ on the formal potentials of some oxidation-reduction couples. Results for $\mathrm{Na}^{+}$are 0 , -0.012 , and $0.096 M^{-1}$ for the $\mathrm{Fe}(\mathrm{II})-\mathrm{Fe}(\mathrm{III}), \mathrm{Hg}(0)-\mathrm{Hg}(\mathrm{I})$, and $\mathrm{Hg}(\mathrm{I})-\mathrm{Hg}(\mathrm{II})$ couples, respectively. For the $\mathrm{Np}(\mathrm{V})-\mathrm{Np}(\mathrm{VI})$ couple, $\beta$ is $-0.059 \mathrm{M}^{-1}$ for $\mathrm{Li}^{+}$and $-0.186 \mathrm{M}^{-1}$ for $\mathrm{Na}^{+}$(Ref. 39). Similarly, $\beta$ is less than $0.136 M^{-1}$ for the Pu(III)-Pu(IV) couple in $\mathrm{HClO}_{4}-\mathrm{NaClO}_{4}$ mixtures. ${ }^{40}$ 
Direct determinations of $\beta$ for kinetic processes are not possible, but we should note that many reactions among cations have one-term rate laws with integral hydrogen-ion dependences. This implies that $\beta$ is small or that there are fortuitous cancellations of medium effects by effects of actual paths.

The results discussed here indicate that $\beta$ for $\mathrm{Li}^{+}-\mathrm{H}^{+}$substitutions is probably smaller than 0.1 or $0.15 \mathrm{M}^{-1}$ but may be larger for $\mathrm{Na}^{+}-\mathrm{H}^{+}$substitutions.

\section{$2-5$}

\section{OUTER-SPHERE REACTIONS}

If steps 3 and 5 in the general mechanism given in Sec. 2-2 are not involved, the coordination shells of the two reactants may be distorted, but they will remain intact throughout the course of the reaction. A theory of such outer-sphere oxidationreduction reactions has been developed by Marcus. ${ }^{41}$ The most readily applicable result of this theory is the expression

$$
\mathrm{k}_{12}=\left(\mathrm{k}_{11} \mathrm{k}_{22} \mathrm{~K}_{12} \mathrm{f}\right)^{1 / 2}
$$

where $\log f=\left(\log K_{12}\right)^{2} /\left[4 \log \left(k_{11} k_{22} / Z^{2}\right)\right]$

$\mathrm{k}_{12}=$ rate constant for the net reaction

$\mathrm{K}_{12}=$ equilibrium constant

$\mathrm{k}_{11}$ and $\mathrm{k}_{22}=$ rate constants for the component self-exchange reactions

$\mathrm{Z}=$ collision frequency for the hypothetically uncharged reactant ions

In terms of free energies this equation becomes

$$
\Delta \mathrm{G}_{12}^{*}=0.5\left(\Delta \mathrm{G}_{11}^{*}+\Delta \mathrm{G}_{22}^{*}+\Delta \mathrm{G}_{12}+\Delta \mathrm{G}^{\mathrm{f}}\right)
$$

where $\Delta G^{f}=\left(\Delta G_{12}\right)^{2} /\left[4\left(\Delta G_{11}^{*}+\Delta G_{22}^{*}-w_{11}-w_{22}-20\right)\right] \mathrm{kJ} / \mathrm{mol}$ and $\mathrm{w}_{11}$ and $\mathrm{w}_{22}$ are the electrostatic work terms as usually defined ${ }^{41}$ and where we assume that $w_{11}+w_{22}=2 w_{12}=2 w_{21}$. The form of these expressions depends primarily on the assumptions that approximately harmonic distortions of coordination and solvent spheres about the ions occur before electron transfer under Franck-Condon restrictions, that the force constants for the distortions are essentially independent of reaction partner, and that the electrostatic work terms are small or cancel.

\section{2-6}

\section{DIFFUSION-CONTROLLED REACTIONS}

Diffusion in solutions is quite rapid, and most reactions are not limited by the rates at which the reactant species can diffuse together. However, collision frequencies 
are greatly reduced for ions of like charge, and it is important to consider the possibility that some of the faster reactions between actinide ions and other highly charged cations might be diffusion controlled.

Debye $^{42}$ used a plausible model to derive a relatively simple expression for collision frequencies of ions in solution. For dilute aqueous solutions at $25^{\circ} \mathrm{C}$ and zero ionic strength, the second-order rate constant is given (in units of $M^{-1} \mathrm{sec}^{-1}$ ) by $\mathrm{k}=7.4 \times 10^{9}\left[\mathrm{x} /\left(\mathrm{e}^{\mathrm{x}}-1\right)\right]$, where $\mathrm{x}=0.7\left(\mathrm{z}_{1} \mathrm{z}_{2}\right) / \mathrm{r}\left(\mathrm{z}_{1}\right.$ and $\mathrm{z}_{2}$ are the charges on the ions $\nmid$ and $r$ is the average radius in nanometers).

To illustrate the magnitude of the charge effect on diffusion-controlled reactions, we assumed that $r$ is $0.4 \mathrm{~nm}$ and calculated $k$ for a range of $\left(z_{1} z_{2}\right)$ values. The results are summarized in Table 2.4

Table 2.4

EFFECTS OF IONIC CHARGE ON DIFFUSIONCONTROLLED RATES ${ }^{\mathrm{a}, \mathrm{b}}$

\begin{tabular}{cc||cc}
\hline $\mathrm{z}_{1} \mathrm{z}_{2}$ & $\mathrm{k}, M^{-1} \mathrm{sec}^{-1}$ & $\mathrm{z}_{1} \mathrm{z}_{2}$ & $\mathrm{k}, M^{-1} \mathrm{sec}^{-1}$ \\
\hline 0 & $7.4 \times 10^{9}$ & 6 & $2.1 \times 10^{6}$ \\
1 & $2.7 \times 10^{9}$ & 9 & $1.7 \times 10^{4}$ \\
2 & $8.1 \times 10^{8}$ & 12 & $1.2 \times 10^{2}$ \\
4 & $4.8 \times 10^{7}$ & & \\
\hline
\end{tabular}

${ }^{\mathrm{a}}$ Values are for $25^{\circ} \mathrm{C}$ and $\mu=0$.

$\mathrm{b}_{\mathrm{A}}$ hydrodynamic effect has been shown ${ }^{43}$ to reduce these values by about $15 \%$; this has been neglected, however, because of the other approximations involved.

These results are only approximate, but they do indicate that diffusion-controlled reactions between $a+3$ and $a+4$ ion, or even between a pair of +3 ions, are slow enough to be measured by rapid-mixing techniques. One of the fastest actinide oxidation-reduction reactions that had been measured by 1971 is the reduction of $\mathrm{Co}\left(\mathrm{NH}_{3}\right)_{5} \mathrm{~N}_{3}^{2+}$ by $\mathrm{U}^{3+}$ (Ref. 18). A second-order rate constant of about $10^{6} M^{-1} \sec ^{-1}$ was reported for $25^{\circ} \mathrm{C}$ and $\mu=0.2 \mathrm{M}$. A reasonable extrapolation to $\mu=0$ reduces the rate constant to about $7 \times 10^{4} \mathrm{M}^{-1} \mathrm{sec}^{-1}$, only about $1 / 30$ the diffusion-controlled limit.

$\lceil$ These charges are in multiples of the charge on the electron. 


\section{KINETICS OF SOME TYPICAL REACTIONS}

In this chapter the kinetics of 12 typical oxidation-reduction reactions of uranium, neptunium, and plutonium ions are discussed. Since their reactions are complicated by radiolytic effects, americium ions are discussed separately in Chap. 6. The reactions discussed here were chosen to illustrate the various ways rates can be determined, the different rate laws observed, and the possible ways these rate laws are interpreted.

3-1

THE Pu(IV)-V(III) REACTION ${ }^{4}$

The kinetics of the $\mathrm{Pu}(\mathrm{IV})-\mathrm{V}$ (III) reaction are discussed in detail because it is typical of oxidation-reduction reactions between highly charged cations. The reactants undergo hydrolysis, and two activated complexes are involved in parallel paths.

The overall reaction in terms of the principal species in acid solution is

$$
\mathrm{Pu}^{4+}+\mathrm{V}^{3+}+\mathrm{H}_{2} \mathrm{O}=\mathrm{Pu}^{3+}+\mathrm{VO}^{2+}+2 \mathrm{H}^{+}
$$

The potentials in Table 2.1 and those given by Latimer ${ }^{45}$ lead to $\Delta \mathrm{G}=-59.8 \mathrm{~kJ} / \mathrm{mol}$ and to an equilibrium quotient of about $3 \times 10^{10} \mathrm{M}^{2}$. Thus the reaction will go essentially to completion in $1 M$ acid at $25^{\circ} \mathrm{C}$. Since the reaction in which V(IV) is 
further oxidized to $\mathrm{V}(\mathrm{V})$ by $\mathrm{Pu}(\mathrm{IV})$ has an equilibrium quotient of only about 0.5 , it is unimportant. The stoichiometry indicated by Eq. 3.1 was confirmed by direct experiment. Reaction rates were followed spectrophotometrically at $469.6 \mathrm{~nm}$ where $\mathrm{Pu}(\mathrm{IV})$ is the principal absorbing species. The reactant concentrations were varied between $1.24 \times 10^{-3} \mathrm{M}$ and $2.52 \times 10^{-3} \mathrm{M}$ for $\mathrm{Pu}(\mathrm{IV})$ and between $1.17 \times 10^{-3} \mathrm{M}$ and $3.29 \times 10^{-3} M$ for $\mathrm{V}(\mathrm{III})$. In all cases the absorbance-vs.-time data agree with the integrated form of a second-order rate law, i.e., first-order in each reactant, and the individual experimental second-order rate constants are independent of initial reactant concentrations. The reaction rate decreases with increasing hydrogen-ion concentration between $0.25 \mathrm{M}$ and $2.0 \mathrm{M}$ at a constant ionic strength of $2.0 \mathrm{M}$ made up with $\mathrm{NaClO}_{4}$. A graph of the logarithm of the apparent second-order rate constant vs. log $\left[\mathrm{H}^{+}\right]$is approximately linear, with a slope of about -1.5 . Thus the experimental results can be described in terms of the rate law:

$$
-\frac{\mathrm{d}[\mathrm{Pu}(\mathrm{IV})]}{\mathrm{dt}}=\mathrm{k}[\mathrm{Pu}(\mathrm{IV})][\mathrm{V}(\mathrm{III})]\left[\mathrm{H}^{+}\right]^{-1.5}
$$

This is called an empirical rate law because it is not written in terms of actual species present in the solution and because not all the exponents are integers. It is useful as a step in determining the composition of the activated complexes and the pattern of paths because it indicates that an average of 1.5 hydrogen ions are released when the activated complex is formed from one Pu(IV) and one V(III). This is not surprising since a total of two hydrogen ions is released in the overall reaction. The rate law in terms of species actually present in the solution can be written as

$$
-\frac{\mathrm{d}[\mathrm{Pu}(\mathrm{IV})]}{\mathrm{dt}}=\left(\mathrm{k}_{1}\left[\mathrm{H}^{+}\right]^{-1}+\mathrm{k}_{2}\left[\mathrm{H}^{+}\right]^{-2}\right)\left[\mathrm{Pu}^{4+}\right]\left[\mathrm{V}^{3+}\right]
$$

Both reactants are known to hydrolyze, and their stoichiometric concentrations are given by $[\mathrm{Pu}(\mathrm{IV})]=\left[\mathrm{Pu}^{4+}\right]+\left[\mathrm{PuOH}^{3+}\right]+\ldots$ and $[\mathrm{V}(\mathrm{III})]=\left[\mathrm{V}^{3+}\right]+\left[\mathrm{VOH}^{2+}\right]+\ldots$ or by $\left[\mathrm{Pu}^{4+}\right]=\left[\mathrm{H}^{+}\right][\mathrm{Pu}(\mathrm{IV})] /\left(\left[\mathrm{H}^{+}\right]+\mathrm{K}_{\mathrm{Pu}}\right)$ and $\left[\mathrm{V}^{3+}\right]=\left[\mathrm{H}^{+}\right][\mathrm{V}(\mathrm{III})] /\left(\left[\mathrm{H}^{+}\right]+\mathrm{K}_{\mathrm{V}}\right)$, where hydrolysis beyond the first stage has been ignored. When these expressions are substituted into Eq. 3.3, the rate law becomes

$$
-\frac{\mathrm{d}[\mathrm{Pu}(\mathrm{IV})]}{\mathrm{dt}}=[\mathrm{Pu}(\mathrm{IV})][\mathrm{V}(\mathrm{III})] \frac{\mathrm{k}_{1}\left[\mathrm{H}^{+}\right]+\mathrm{k}_{2}}{\left(\left[\mathrm{H}^{+}\right]+\mathrm{K}_{\mathrm{Pu}}\right)\left(\left[\mathrm{H}^{+}\right]+\mathrm{K}_{\mathrm{V}}\right)}
$$

At $25^{\circ} \mathrm{C}, \mathrm{K}_{\mathrm{Pu}}=5.4 \times 10^{-2} M$ for $\mu=2 M$, but $\mathrm{K}_{\mathrm{V}}$ is negligible with respect to $\left[\mathrm{H}^{+}\right]$; the value is only about $2 \times 10^{-3} \mathrm{M}$. Thus Eq. 3.4 can be simplified by omitting $\mathrm{K}_{\mathrm{V}}$. The simplified expression was confirmed by the linearity of graphs of $k^{\prime \prime}\left(\left[\mathrm{H}^{+}\right]+\mathrm{K}_{\mathrm{Pu}}\right)$ vs. $\left[\mathrm{H}^{+}\right]^{-1}$, where $\mathrm{k}^{\prime \prime}$ is the second-order rate constant observed at a particular $\left[\mathrm{H}^{+}\right]$and temperature. At $20^{\circ} \mathrm{C}, \mathrm{k}_{1}$ was found to be $11.9 \mathrm{sec}^{-1}$ and $\mathrm{k}_{2}$ to be $20.1 M \mathrm{sec}^{-1}$. Values for the rate constants were also determined at four other temperatures down to $2.4^{\circ} \mathrm{C}$. 
As pointed out in Sec. 2-3, the rate law alone does not identify the actual reactant species. In the present case, reactions either between $\mathrm{VOH}^{2+}$ and $\mathrm{Pu}^{4+}$ or between $\mathrm{V}^{3+}$ and $\mathrm{PuOH}^{3+}$ are consistent with the $\mathrm{k}_{1}$ term in Eq. 3.3. The $\mathrm{k}_{2}$ term can be explained in terms of reactions between $\mathrm{VOH}^{2+}$ and $\mathrm{PuOH}^{3+}$, between $\mathrm{V}^{3+}$ and $\mathrm{Pu}(\mathrm{OH})_{2}^{2+}$, or between $\mathrm{V}(\mathrm{OH})_{2}^{+}$and $\mathrm{Pu}^{4+}$. For the last possibility, $\mathrm{k}_{2}$ would be given by $\mathrm{KVK}_{\mathrm{V}}^{\prime} \mathrm{k}^{\prime}$, where $\mathrm{K}_{\mathrm{V}}$ and $\mathrm{K}_{\mathrm{V}}^{\prime}$ are the first and second hydrolysis constants for $\mathrm{V}^{3+}$ and $\mathrm{k}^{\prime}$ is the second-order rate constant defined in terms of the species $\mathrm{V}(\mathrm{OH})_{2}^{+}$and $\mathrm{Pu}^{4+}$. Values for $\mathrm{K}_{\mathrm{V}}$ and $\mathrm{K}_{\mathrm{V}}^{\prime}$ are about $2 \times 10^{-3} \mathrm{M}$ and $2.5 \times 10^{-4} \mathrm{M}$, respectively; thus $\mathrm{k}^{\prime}$ would be about $4 \mathrm{x}$ $10^{7} \mathrm{M}^{-1} \mathrm{sec}^{-1}$. Table 2.4 shows that this value is near the diffusion-controlled limit for reactions between +1 and +4 ions. We should note, however, that the diffusion limits apply to infinitely dilute solutions and $\mathrm{k}^{\prime}$ applies to $\mu=2 M$. Reactions between ions of like charge become slower as the ionic strength is decreased, and using reasonable values for the parameters in the extended Debye-Hückel expression (see Chap. 7) gives a factor of about 30 between $\mu=2 M$ and $\mu=0 M$ for reactions between +1 and +4 ions. This calculation shows that, although $\mathrm{V}(\mathrm{OH})_{2}^{+}$is a very minor constituent of the solution, its concentration is large enough to be kinetically important. Similar conclusions can be reached about $\mathrm{Pu}(\mathrm{OH})_{2}^{2+}$.

Despite the uncertainty about the actual rate-determining steps, the formal processes for formation of the two activated complexes from the principal reactants are unambiguous. The two net activation processes, together with their thermodynamic quantities of activation, are listed in Table 3.1 .

Table 3.1

NET ACTIVATION PROCESSES AND THERMODYNAMIC QUANTITIES OF ACTIVATION FOR THE Pu(IV)-V(III) REACTION $\dagger$

\begin{tabular}{cccc}
\hline Net activation process & $\begin{array}{c}\Delta \mathrm{G}^{*}, \\
\mathrm{~kJ} / \mathrm{mol} \\
(\mathrm{kcal} / \mathrm{mol})\end{array}$ & $\begin{array}{c}\Delta \mathbf{H J} / \mathrm{mol} \\
(\mathrm{kcal} / \mathrm{mol})\end{array}$ & $\begin{array}{c}\Delta \mathbf{S}^{*}, \\
\mathbf{J} / \mathbf{m o l} \cdot \mathbf{K} \\
(\mathrm{cal} / \mathbf{m o l} \cdot \mathrm{deg})\end{array}$ \\
\hline $\mathrm{Pu}^{4+}+\mathrm{V}^{3+}+\mathrm{H}_{2} \mathrm{O}=\left[{ }^{*}\right]^{6+}+\mathrm{H}^{+}$ & $\begin{array}{c}65.6 \pm 0.04 \\
(15.68 \pm 0.01)\end{array}$ & $\begin{array}{c}71.5 \pm 2 \\
(17.1 \pm 0.5)\end{array}$ & $20 \pm 7$ \\
$\mathrm{Pu}^{4+}+\mathrm{V}^{3+}+\mathrm{H}_{2} \mathrm{O}=\left[{ }^{*}\right]^{5+}+2 \mathrm{H}^{+}$ & $64.0 \pm 0.04$ & $90 \pm 1.7$ & $87 \pm 6$ \\
& $(15.30 \pm 0.01)$ & $(21.5 \pm 0.04)$ & $(20.8 \pm 1.4)$ \\
\hline
\end{tabular}

$†$ Values are for $25^{\circ} \mathrm{C}$ and $\mu=2.0 M$.

\section{$3-2$}

\section{THE U(IV)-Fe(III) REACTION ${ }^{46}$}

The U(IV)-Fe(III) reaction is another example of a reaction between highly charged cations both of which undergo appreciable hydrolysis. The pertinent oxidation potentials indicate that the reaction should be 


$$
\mathrm{U}^{4+}+2 \mathrm{Fe}^{3+}+2 \mathrm{H}_{2} \mathrm{O}=\mathrm{UO}_{2}^{2+}+2 \mathrm{Fe}^{2+}+4 \mathrm{H}^{+}
$$

The stoichiometry indicated by this equation was confirmed by experiments showing that 1.98 moles of $\mathrm{Fe}(\mathrm{II})$ formed for each mole of U(IV) consumed. Rates were determined by removing samples of the reacting mixture periodically and quenching them in solutions of $o$-phenanthroline containing an equimolar mixture of $\mathrm{NH}_{4} \mathrm{~F}$ and $\mathrm{NH}_{4}\left(\mathrm{CH}_{3} \mathrm{COO}\right)$ at a $\mathrm{pH}$ of 4 . This solution effectively stopped the reaction and provided a convenient colorimetric determination of the product, $\mathrm{Fe}(\mathrm{II})$. The data are in accord with the integrated form of the second-order rate law:

$$
-\frac{\mathrm{d}[\mathrm{U}(\mathrm{IV})]}{\mathrm{dt}}=\mathrm{k}^{\prime \prime}[\mathrm{U}(\mathrm{IV})][\mathrm{Fe}(\mathrm{III})]
$$

This rate law was further tested by varying the initial concentrations of $\mathrm{Fe}$ (III) in the range 1.2 to $52 \times 10^{-5} \mathrm{M}$ and U(IV) in the range 1.7 to $3.6 \times 10^{-5} \mathrm{M}$. Over this very wide range in concentrations, the experimental values of $k^{\prime}$ agreed with the average with a mean deviation of only $5 \%$.

The rate law, Eq. 3.6, shows that the rate-determining step (or steps) involves a reaction between one $\mathrm{U}(\mathrm{IV})$ and one $\mathrm{Fe}(\mathrm{III})$ to give the intermediate $\mathrm{U}(\mathrm{V})$ or possibly a binuclear complex such as $\mathrm{Fe} \cdot \mathrm{UO}_{2}^{3+}$. The details of the reactions that follow the rate-determining step are difficult to determine, but the interme diate probably reacts rapidly with more $\mathrm{Fe}(\mathrm{III})$ to give the final products.

The reaction rate increases markedly between $1.0 M$ and $0.1 M \mathrm{HClO}_{4}$ at constant ionic strength. Graphs of $\log \mathrm{k}^{\prime \prime}$ vs. $\log \left[\mathrm{H}^{+}\right]$give an empirical hydrogen-ion dependence of -1.8 . This suggests the following rate law in terms of the principal species present in the solutions:

$$
\frac{\mathrm{d}[\mathrm{U}(\mathrm{IV})]}{\mathrm{dt}}=\left[\mathrm{U}^{4+}\right]\left[\mathrm{Fe}^{3+}\right]\left(\mathrm{k}_{1}\left[\mathrm{H}^{+}\right]^{-1}+\mathrm{k}_{2}\left[\mathrm{H}^{+}\right]^{-2}\right)
$$

If we allow for hydrolysis, $\left[\mathrm{Fe}^{3+}\right]$ is equal to $[\mathrm{Fe}(\mathrm{III})]\left[\mathrm{H}^{+}\right] /\left(\left[\mathrm{H}^{+}\right]+\mathrm{K}_{\mathrm{Fe}}\right)$ and $\left[\mathrm{U}^{4+}\right]$ is equal to $[\mathrm{U}(\mathrm{IV})]\left[\mathrm{H}^{+}\right] /\left(\left[\mathrm{H}^{+}\right]+\mathrm{K}_{\mathrm{U}}\right)$. These expressions are valid when the hydrogen-ion concentrations are greater than about $0.1 \mathrm{M}$, where the concentrations of hydrolyzed species other than $\mathrm{FeOH}^{2+}$ and $\mathrm{UOH}^{3+}$ are negligibly sinall. When we substitute these expressions into Eq. 3.7, we get

$$
\mathrm{k}^{\prime \prime}=\frac{\mathrm{k}_{1}\left[\mathrm{H}^{+}\right]+\mathrm{k}_{2}}{\left(\left[\mathrm{H}^{+}\right]+\mathrm{K}_{\mathrm{Fe}}\right)\left(\left[\mathrm{H}^{+}\right]+\mathrm{K}_{\mathrm{U}}\right)}
$$

Since the hydrolysis constants, $\mathrm{K}_{\mathrm{Fe}}$ and $\mathrm{K}_{\mathrm{U}}$, are known, the applicability of Eq. 3.8 could be confirmed by the linearity of graphs of $\mathrm{k}^{\prime \prime}\left(\left[\mathrm{H}^{+}\right]+\mathrm{K}_{\mathrm{Fe}}\right)\left(\left[\mathrm{H}^{+}\right]+\mathrm{K}_{\mathrm{U}}\right)$ vs. $\left[\mathrm{H}^{+}\right]$ for the data at the various temperatures. Values for $k_{1}$ and $k_{2}$ were determined from the slopes and intercepts of the graphs. 
The rate law, Eq. 3.7, shows that there are two parallel rate-determining steps, but the actual reacting species are unknown. The rate law does specify the net activation processes, which are given in Table 3.2.

Measurements were made between 3.1 and $24.8^{\circ} \mathrm{C}$, and values for $\mathrm{k}_{1}$ and $\mathrm{k}_{2}$ were determined as described. Graphs of $\log k_{1}$ and $\log k_{2}$ vs. $1 / \mathrm{T}$ were good straight lines, indicating activation energies of 22.5 and $24.4 \mathrm{kcal} / \mathrm{mol}$. Similarly, graphs of $1 \mathrm{og}$ $\left(\mathrm{k}_{1} / \mathrm{T}\right)$ and $\log \left(\mathrm{k}_{2} / \mathrm{T}\right)$ vs. $1 / \mathrm{T}$ are straight lines, in accordance with $\mathrm{Eq} .2 .1$, giving $\Delta \mathrm{H}^{*}$ values of $21.5 \pm 0.2$ and $23.6 \pm 0.3 \mathrm{kcal} / \mathrm{mol}$.

Table 3.2

NET ACTIVATION PROCESSES AND THERMODYNAMIC QUANTITIES OF ACTIVATION FOR THE U(IV)-Fe(III) REACTION *

\begin{tabular}{|c|c|c|c|}
\hline Net activation process & $\begin{array}{c}\Delta \mathrm{G}^{*}, \dot{+} \\
\mathbf{k J} / \mathrm{mol} \\
(\mathrm{kcal} / \mathrm{mol})\end{array}$ & $\begin{array}{c}\Delta \mathrm{H}^{*} \\
\mathrm{~kJ} / \mathrm{mol} \\
(\mathrm{kcal} / \mathrm{mol})\end{array}$ & $\begin{array}{c}\Delta \mathrm{S}^{*}, \neq \\
\mathbf{J} / \mathrm{mol} \cdot \mathbf{K} \\
(\mathrm{cal} / \mathrm{mol} \cdot \mathrm{deg})\end{array}$ \\
\hline $\mathrm{U}^{4+}+\mathrm{Fe}^{3+}+\mathrm{H}_{2} \mathrm{O}=\left[{ }^{*}\right]^{6+}+\mathrm{H}^{+}$ & $\begin{array}{c}71.2 \\
(17.01)\end{array}$ & $\begin{array}{c}75 \pm 11 \\
(17.9 \pm 2.6)\end{array}$ & $\begin{array}{c}13 \pm 39 \\
(3 \pm 9)\end{array}$ \\
\hline $\mathrm{U}^{4+}+\mathrm{Fe}^{3+}+\mathrm{H}_{2} \mathrm{O}=\left[{ }^{*}\right]^{5+}+2 \mathrm{H}^{+}$ & $\begin{array}{l}66.9 \\
(16.00)\end{array}$ & $\begin{aligned} 101 & \pm 2 \\
(24.1 & \pm 0.5)\end{aligned}$ & $\begin{aligned} 113 & \pm 7 \\
(27.1 & \pm 1.7)\end{aligned}$ \\
\hline
\end{tabular}

$\dagger$ Values are for $25^{\circ} \mathrm{C}$ and $\mu=1.02 \mathrm{M}$.

$\ddagger$ Values are calculated under the assumption that the overall rate is twice that of the rate-determining step.

Treating the two sets of $\mathrm{k}$ values separately has the drawback that the best fit of one set will generally be inconsistent with the best fit of the other. Also, since the two sets are not independent of each other, reliable estimates of the precision of the activation parameters cannot be determined from the fit of the individual sets to the individual lines. It is better to use a least-squares procedure to find values of the activation parameters $\left(\Delta \mathrm{H}_{1}^{*}, \Delta \mathrm{S}_{1}^{*}, \Delta \mathrm{H}_{2}^{*}\right.$, and $\left.\Delta \mathrm{S}_{2}^{*}\right)$ which best reproduce all the hydrogen-ion- and temperature-dependence data simultaneously. Values determined this way are listed in Table 3.2 , which shows that the $\Delta H^{*}$ values are distinctly different from those obtained from the individual $\mathrm{k}$ values.

Three different rate-determining steps are all consistent with the second net activation process in Table 3.2. They are the reactions between $\mathrm{UOH}^{3+}$ and $\mathrm{FeOH}^{2+}$ (with a second-order rate constant $\left.\mathrm{k}_{11}\right)$, between $\mathrm{U}(\mathrm{OH})_{2}^{2+}$ and $\mathrm{Fe}^{3+}\left(\mathrm{k}_{20}\right)$, and between $\mathrm{U}^{4+}$ and $\mathrm{Fe}(\mathrm{OH})_{2}^{+}\left(\mathrm{k}_{02}\right)$. It is of interest to see if any of these possibilities can be ruled out because of inconsistencies with other requirements. If the $k_{11}$ path is important, the observed rate constant $\mathrm{k}_{2}$ will be related to $\mathrm{k}_{11}$ by the equation $\mathrm{k}_{11}=$ $\mathrm{k}_{2} /\left(\mathrm{K}_{\mathrm{Fe}} \mathrm{K}_{\mathrm{U}}\right)$. At $25^{\circ} \mathrm{C}$ and $\mu=1 M, \mathrm{k}_{11}$ is $2.34 \times 10^{5} M^{-1} \mathrm{sec}^{-1}$, a value well within the diffusion-controlled limit (see Table 2.4). Also, for the heat of activation, $\Delta H_{11}^{*}$ is $\Delta \mathrm{H}_{2}^{*}-\Delta \mathrm{H}_{\mathrm{Fe}}-\Delta \mathrm{H}_{\mathrm{U}}$, where the two last terms are for the hydrolysis of $\mathrm{Fe}^{3+}$ and $\mathrm{U}^{4+}$, 
respectively. Using the known values for the heats of hydrolysis, we find that $\Delta \mathrm{H}_{1}^{*}$ is $101-52-44=5 \mathrm{~kJ} / \mathrm{mol}$. Although this is quite small, it is not an impossible value in view of other low values that have been observed; e.g., for the $\mathrm{U}^{3+}-\mathrm{NpO}_{2}^{2+}$ reaction, $\Delta \mathrm{H}^{*}=4.2 \mathrm{~kJ} / \mathrm{mol}$, and for the $\mathrm{U}^{3+}-\mathrm{UO}_{2}^{+}$reaction, $\Delta \mathrm{H}^{*}=7.5 \mathrm{~kJ} / \mathrm{mol}$.

Not enough is known about the formation of $\mathrm{U}(\mathrm{OH})_{2}^{2+}$ and $\mathrm{Fe}(\mathrm{OH})_{2}^{+}$to enable us to apply similar quantitative arguments to the $\mathrm{k}_{20}$ and $\mathrm{k}_{02}$ paths. However, reasonable values for the hydrolysis constants and heats of hydrolysis lead to plausible values for the rate constants. Thus the $\mathrm{Fe}(\mathrm{III})-\mathrm{U}(\mathrm{IV})$ reaction illustrates a typical situation in which the formulas of the activated complexes can readily be determined but the detailed mechanism of their formation can be determined only with great difficulty, if at all.

The $\mathrm{Np}(\mathrm{V})-\mathrm{Co}(\mathrm{III})$ reaction $^{47}$ illustrates the various ways of interpreting a small observed hydrogen-ion dependence.

The reaction was studied spectrophotometrically at $980.5 \mathrm{~nm}$, where $\mathrm{NpO}_{2}^{+}$is the principal absorbing species. The stoichiometry is given by

$$
\mathrm{NpO}_{2}^{+}+\mathrm{Co}^{3+}=\mathrm{NpO}_{2}^{2+}+\mathrm{Co}^{2+}
$$

in acid solutions. The rate of the reaction was studied at six hydrogen-ion concentrations from $0.26 \mathrm{M}$ to $2.1 \mathrm{M}$ and at four temperatures between 5 and $25^{\circ} \mathrm{C}$. The rate is strictly first order in each of the metal ions, but the apparent second-order rate constants decrease about $25 \%$ when concentrations of $\mathrm{HClO}_{4}$ increase from $0.26 \mathrm{M}$ to $2.1 \mathrm{M}$ at constant ionic strength $\left(\mathrm{LiClO}_{4}\right)$. A satisfactory empirical rate law is

$$
-\frac{\mathrm{d}\left[\mathrm{NpO}_{2}^{+}\right]}{\mathrm{dt}}=\mathrm{k}^{\prime \prime}\left[\mathrm{NpO}_{2}^{+}\right]\left[\mathrm{Co}^{3+}\right]\left[\mathrm{H}^{+}\right]^{\mathrm{n}}
$$

where $\mathrm{n}$ ranges from -0.06 at $5^{\circ} \mathrm{C}$ to -0.112 at $25^{\circ} \mathrm{C}$. The discussion in Sec. $2-4$ shows that small hydrogen-ion dependences such as this can be explained in several ways. For this reason the apparent second-order rate constants were treated by least squares, as described in Sec. 3-2, with three different functional forms for $k^{\prime \prime}$ : (1) $\mathrm{k}^{\prime \prime}=\mathrm{k}_{0}+\mathrm{k}_{1}\left[\mathrm{H}^{+}\right]^{-1}$, (2) $\mathrm{k}^{\prime \prime}=\left\{\mathrm{k}_{0}^{-1}+\left(\mathrm{k}_{1}\left[\mathrm{H}^{+}\right]^{-1}\right)^{-1}\right\}^{-1}$, and (3) $\mathrm{k}^{\prime \prime}=\mathrm{k}_{0} \exp \{\beta(1+$ $\left.\alpha \mathrm{t})\left[\mathrm{H}^{+}\right]\right\}$. The temperature dependence of $\beta$ was assumed to be linear, as indicated; the temperature dependences of the rate constants were assumed to be given by the Eyring equation; and best values for the parameters were determined by least squares. The calculations showed that the temperature dependence of $\beta$ is not statistically significant; repeating the calculations without it gave essentially the same results. 
Table 3.3

INTERPRETATIONS OF THE HYDROGEN-ION DEPENDENCE OF THE Np(V)-Co(III) REACTION†

\begin{tabular}{|c|c|c|c|c|c|c|c|}
\hline $\begin{array}{l}\text { Apparent second-order } \\
\text { rate constant }\end{array}$ & $\begin{array}{c}\Delta \mathbf{H}_{0}^{*} \\
\mathrm{~kJ} / \mathrm{mol} \\
(\mathrm{kcal} / \mathrm{mol})\end{array}$ & $\begin{array}{c}\Delta \mathrm{S}_{0}^{*}, \\
\mathrm{~J} / \mathrm{mol} \cdot \mathrm{K} \\
(\mathrm{cal} / \mathrm{mol} \cdot \mathrm{deg})\end{array}$ & $\begin{array}{c}\Delta \mathbf{H}_{1}^{*}, \\
\mathrm{~kJ} / \mathrm{mol} \\
(\mathrm{kcal} / \mathrm{mol})\end{array}$ & $\begin{array}{c}\Delta S_{1}^{*} \\
J / \mathrm{mol} \cdot \mathbf{K} \\
(\mathrm{cal} / \mathrm{mol} \cdot \operatorname{deg})\end{array}$ & $\begin{array}{c}\beta \\
M^{-1}\end{array}$ & $\begin{array}{c}\alpha, \\
\operatorname{deg}^{-1}\end{array}$ & Deviation $\S$ \\
\hline $\mathrm{k}^{\prime \prime}=\mathrm{k}_{0}+\mathrm{k}_{1}\left[\mathrm{H}^{+}\right]^{-1}$ & $\begin{array}{c}50.2 \pm 0.9 \\
(12.0 \pm 0.2)\end{array}$ & $\begin{array}{l}-29.5 \pm 3.2 \\
(-7.0 \pm 0.8)\end{array}$ & $\begin{array}{c}82 \pm 10 \\
(19.7 \pm 2.4)\end{array}$ & $\begin{array}{r}61 \pm 34 \\
(14.5 \pm 8)\end{array}$ & & & 6.3 \\
\hline $\mathrm{k}^{\prime \prime}=\left\{\mathrm{k}_{0}^{-1}+\left(\mathrm{k}_{1}\left[\mathrm{H}^{+}\right]^{-1}\right)^{-1}\right\}^{-1}$ & $\begin{array}{c}57.0 \pm 4.6 \\
(13.6 \pm 1.1)\end{array}$ & $\begin{array}{l}-4.1 \pm 15 \\
(-1.0 \pm 3.7)\end{array}$ & $\begin{array}{c}26 \pm 31 \\
(6.3 \pm 7.4)\end{array}$ & $\begin{array}{l}-93 \pm 104 \\
(-22 \pm 25)\end{array}$ & & & 14.2 \\
\hline \multirow[t]{2}{*}{$\mathrm{k}^{\prime \prime}=\mathrm{k}_{0} \exp \left\{\beta(1+\alpha \mathrm{t})\left[\mathrm{H}^{+}\right]\right\}$} & $\begin{array}{c}56.1 \pm 4.6 \\
(13.4 \pm 1.1)\end{array}$ & $\begin{array}{l}-7.1 \pm 15.5 \\
(-1.7 \pm 3.7)\end{array}$ & & & $-0.45 \pm 0.1$ & $0.086 \pm 0.3$ & 14.6 \\
\hline & $\begin{array}{c}52.3 \pm 1.5 \\
(12.5 \pm 0.4)\end{array}$ & $\begin{array}{l}-20.5 \pm 5 \\
(-4.9 \pm 1.2)\end{array}$ & & & $-0.11 \pm 0.02$ & 0 (fixed) & 13.5 \\
\hline
\end{tabular}

The rate law is $-\mathrm{d}[\mathrm{Np}(\mathrm{V})] / \mathrm{dt}=\mathrm{k}^{\prime \prime}[\mathrm{Np}(\mathrm{V})][\mathrm{Co}(\mathrm{III})]$

$¥$ The uncertainties listed for the parameters are the standard deviations.

\$ Root-mean-square deviation between observed and calculated $\mathrm{k}^{\prime \prime}$ values. The data were weighted according to their individual standard deviations. The root-mean-square average of these individual standard deviations was $3.7 \mathrm{M}^{-1} \mathrm{sec}^{-1}$. 
The results of these calculations, summarized in Table 3.3, show that the activation parameters for the major, hydrogen-ion-independent, path do not depend strongly on the form assumed for the minor term in the rate law. We recommend the interpretation based on parallel paths since it fits the data much better than the others. Other interpretations cannot be excluded with certainty, however, because they may also fit the data within the experimental error. For example, the root-mean-square deviation of $14.2 \mathrm{M}^{1} \mathrm{sec}^{-1}$, found in the second calculation, corresponds to a mean deviation of only $5.3 \%$.

The oxidation of $\mathrm{Np}(\mathrm{V})$ complexed with $\mathrm{Cr}(\mathrm{III})$ was also studied. When a mixture of hexaquo $\mathrm{Cr}^{3+}$ is allowed to stand in solution with $\mathrm{NpO}_{2}^{+}$, a definite complex, $\mathrm{Cr} \cdot \mathrm{NpO}_{2}^{4+}$, is formed. This can be separated from the mixture by ion-exchange techniques. ${ }^{29.33}$ Similar complexes containing uranium ${ }^{30}$ or plutonium ${ }^{32}$ can also be made.

The stoichiometry of the reaction between the complex and $\mathrm{Co}(\mathrm{III})$ is given by

$$
\mathrm{Cr} \cdot \mathrm{NpO}_{2}^{4+}+\mathrm{Co}^{3+}=\mathrm{Cr}^{3+}+\mathrm{NpO}_{2}^{2+}+\mathrm{Co}^{2+}
$$

This reaction, too, was studied spectrophotometrically over a range of temperatures and hydrogen-ion concentrations. The empirical rate law has the form

$$
\frac{\mathrm{d}\left[\mathrm{NpO}_{2}^{2+}\right]}{\mathrm{dt}}=\mathrm{k}^{\prime \prime}\left[\mathrm{Cr} \cdot \mathrm{NpO}_{2}^{4+}\right]\left[\mathrm{Co}^{3+}\right]\left[\mathrm{H}^{+}\right]^{-1.1}
$$

Thus the reaction is predominantly inverse first power in $\left[\mathrm{H}^{+}\right]$. Again, the small deviation from this dependence can be explained by parallel reactions, by consecutive reactions, or by a medium effect. Our calculations show that the three different assumptions are about equally satisfactory with respect to fitting the observed hydrogen-ion- and temperature-dependence data. We got the best fit by assuming consecutive reactions and the poorest by assuming parallel reactions. The differences among the possibilities are not significant, however, since the weighted average deviation for the best fit is only $4 \%$ less than that for the poorest. Thus there is no evidence that the minor term in the rate law results from a distinct activation process occurring either in parallel with or consecutive to the principal one. The activation parameters for the principal path, inverse in $\left[\mathrm{H}^{+}\right]$, calculated under the three assumptions agree within their standard deviations. The average values are given in Table 3.4, along with those for the reaction of uncomplexed $\mathrm{Np}(\mathrm{V})$.

When we compare the second and third processes, we see that, although the presence of $\mathrm{Cr}(\mathrm{III})$ decreases $\Delta \mathrm{H}^{*}$, the decrease is more than compensated for by the effect of the higher charge in decreasing $\Delta S^{*}$. Thus the net effect is a reduction in the rate. 
Table 3.4

\section{NET ACTIVATION PROCESSES AND THERMODYNAMIC QUANTITIES OF ACTIVATION} FOR Np(V)-Co(III) REACTIONS $\dagger$

\begin{tabular}{lccc}
\hline Net activation process & $\begin{array}{c}\Delta \mathrm{G}^{*}, \\
\mathrm{~kJ} / \mathrm{mol} \\
(\mathrm{kcal} / \mathrm{mol})\end{array}$ & $\begin{array}{c}\Delta \mathrm{HJ} / \mathrm{mol} \\
(\mathbf{k c a l} / \mathrm{mol})\end{array}$ & $\begin{array}{c}\Delta \mathrm{S}^{*}, \\
\mathrm{~J} / \mathrm{mol} \cdot \mathbf{K} \\
(\mathbf{c a l} / \mathbf{m o l} \cdot \mathbf{d e g})\end{array}$ \\
\hline $\mathrm{Co}^{3+}+\mathrm{NpO}_{2}^{+}=\left[{ }^{*}\right]^{4+}$ & 59.0 & $50.2 \pm 0.8$ & $-29 \pm 3$ \\
$\mathrm{Co}^{3+}+\mathrm{NpO}_{2}^{+}+\mathrm{H}_{2} \mathrm{O}=\left[{ }^{*}\right]^{3+}+\mathrm{H}^{+}$ & $(14.1)$ & $(12.0 \pm 0.2)$ & $(-7 \pm 1)$ \\
$\mathrm{Co}^{3+}+\mathrm{Cr} \cdot \mathrm{NpO}_{2}^{4+}+\mathrm{H}_{2} \mathrm{O}=\left[{ }^{*}\right]^{6+}+\mathrm{H}^{+}$ & 64.4 & $82.4 \pm 10$ & $62 \pm 34$ \\
& $(15.4)$ & $(19.7 \pm 2.4)$ & $(14.8 \pm 8)$ \\
& 70.3 & $77.0 \pm 3.3$ & $23 \pm 11$ \\
& $(16.8)$ & $(18.4 \pm 0.8)$ & $(5.4 \pm 2.7)$ \\
\hline
\end{tabular}

$\dagger$ Values are for $25^{\circ} \mathrm{C}$ and $\mu=2.1 \mathrm{M}\left(\mathrm{LiClO}_{4}\right)$.

\section{3-4}

\section{THE Np(V)-V(III) REACTION ${ }^{48}$}

The $\mathrm{Np}(\mathrm{V})-\mathrm{V}(\mathrm{III})$ reaction is interesting because the rate law shows the operation of parallel paths that do not differ merely by one or two hydrogen ions as in the reactions discussed previously (e.g., the Fe(III)-U(IV) reaction).

The course of the reaction was followed spectrophotometrically by use of either the $\mathrm{Np}(\mathrm{V})$ band at $980 \mathrm{~nm}$ or the $\mathrm{Np}(\mathrm{VI})$ band at $960 \mathrm{~nm}$. At hydrogen-ion concentrations greater than $0.5 \mathrm{M}$, the stoichiometry of the reaction is given by

$$
\mathrm{V}^{3+}+\mathrm{NpO}_{2}^{+}+2 \mathrm{H}^{+}=\mathrm{VO}^{2+}+\mathrm{Np}^{4+}+\mathrm{H}_{2} \mathrm{O}
$$

At lower acidities, however, appreciable concentrations of $\mathrm{Np}^{3+}$ were formed by the rapid equilibrium:

$$
\mathrm{V}^{3+}+\mathrm{Np}^{4+}+\mathrm{H}_{2} \mathrm{O} \rightleftharpoons \mathrm{VO}^{2+}+\mathrm{Np}^{3+}+2 \mathrm{H}^{+}
$$

for which the equilibrium quotient, $\mathrm{Q}_{14}$, was found to be about $6 \times 10^{-4} \mathrm{M}^{2}$ at $25^{\circ} \mathrm{C}$ in $3 M(\mathrm{H}, \mathrm{Li}) \mathrm{ClO}_{4}$.

The rate was found to be first order in each of the reactants $V(I I I)$ and $N p(V)$ but to be catalyzed by $\mathrm{Np}$ (IV) and inhibited by V(IV). At constant hydrogen-ion concentration, the rate is given by

$$
-\frac{d[N p(V)]}{d t}=k_{a}^{\prime \prime}[V(I I I)][N p(V)]+\frac{k_{b}^{\prime \prime}[V(I I I)][N p(I V)][N p(V)]}{[V(I V)]}
$$


The $k_{a}^{\prime \prime}$ and $k_{b}^{\prime \prime}$ terms show that there are two parallel rate-determining steps. The first term corresponds to the direct reaction (Eq. 3.13) and the form of the second term shows that its activated complex is formed from V(III), $N p(I V)$, and $N p(V)$ with the prior loss of V(IV). This means that the activated complex contains no vanadium and has an average oxidation number of +4 . This suggests a mechanism consisting of reactions 3.13 and 3.14 , followed by the rate-determining oxidation of $N p$ (III) by $\mathrm{Np}(\mathrm{V})$ :

$$
\mathrm{Np}(\mathrm{III})+\mathrm{Np}(\mathrm{V})=2 \mathrm{~Np}(\mathrm{IV})
$$

If we assume that $\mathrm{Np}$ (III) is formed at essentially the same rate as that at which it reacts (so that its net rate of change is small compared with the rate of the overall reaction), the steady-state approximation can be applied:

$$
[\mathrm{Np}(\mathrm{III})]=\frac{\mathrm{k}_{14}[\mathrm{~V}(\mathrm{III})][\mathrm{Np}(\mathrm{IV})]}{\mathrm{k}_{-14}[\mathrm{~V}(\mathrm{IV})]+\mathrm{k}_{16}[\mathrm{~Np}(\mathrm{~V})]}
$$

where $k_{14}$ refers to Eq. $3.14, k_{-14}$ to the reverse of Eq. 3.14, and $k_{16}$ to Eq. 3.16. The rate of the overall reaction is then given by

$$
\frac{\mathrm{d}[\mathrm{Np}(\mathrm{V})]}{\mathrm{dt}}=\mathrm{k}_{13}[\mathrm{~Np}(\mathrm{~V})][\mathrm{V}(\mathrm{III})]+\frac{\mathrm{k}_{14} \mathrm{k}_{16}[\mathrm{~V}(\mathrm{III})][\mathrm{Np}(\mathrm{IV})][\mathrm{Np}(\mathrm{V})]}{\mathrm{k}_{-14}[\mathrm{~V}(\mathrm{IV})]+\mathrm{k}_{16}[\mathrm{~Np}(\mathrm{~V})]}
$$

Since $\mathrm{k}_{-14}[\mathrm{~V}(\mathrm{IV})]$ is known to be much larger than $\mathrm{k}_{16}[\mathrm{~Np}(\mathrm{~V})], \mathrm{Eq} .3 .18$ reduces to Eq. 3.15, where the experimental rate constant $k_{b}^{\prime \prime}$ is given by $k_{14} k_{16} / k_{-14}$ or $k_{16} Q_{14}$. Both $k_{16}$ and the equilibrium quotient, $Q_{14}$, were measured separately, and their product was found to be significantly less than $\mathrm{k}_{\mathrm{b}}^{\prime \prime}$. This discrepancy is attributed to unknown cataly tic impurities.

The experimental rate constant $k_{a}^{\prime \prime}$ is independent of $\left[\mathrm{H}^{+}\right]$, and $k_{b}^{\prime \prime}$ shows an inverse 1.6 power dependence, consistent with the $\left[\mathrm{H}^{+}\right]$dependences of equilibrium 3.14 and reaction 3.16 and the proposed mechanism. The heat of activation for reaction 3.13 was determined from the temperature dependence of $\mathrm{k}_{\mathrm{a}}^{\prime \prime}$ between 15 and $35^{\circ} \mathrm{C}$; the value is $\Delta H^{*}=61 \pm 3 \mathrm{~kJ} / \mathrm{mol}$.

THE V(II)-U(VI) REACTION

The reaction between $\mathrm{V}(\mathrm{II})$ and $\mathrm{U}(\mathrm{VI})^{49}$ shows one way that $\mathrm{U}(\mathrm{VI})$ can act as a catalyst for oxidation-reduction reactions and how this action can be used to determine the rate of reduction of U(VI).

The reaction between $\mathrm{V}(\mathrm{II})$ and $\mathrm{V}$ (IV) to give $\mathrm{V}(\mathrm{III})$ is relatively slow in acid solution; e.g., the second-order rate constant at $25^{\circ} \mathrm{C}$ is $1.6 M^{-1} \mathrm{sec}^{-1}$ in $1 M$ 
$\mathrm{HClO}_{4}-1 M \mathrm{LiClO}_{4}$ (Ref. 50). When as little as $10^{-4} \mathrm{M} \mathrm{U}(\mathrm{VI})$ is present, however, the initial value of the apparent second-order rate constant is increased by a factor of 2.75 if the V(IV) concentration is $2.5 \times 10^{-3} \mathrm{M}$. This catalytic effect is in accord with the following reaction scheme:

$$
\begin{aligned}
& V(I I)+U(V I)=V(I I I)+U(V) \\
& U(V)+V(I V)=U(V I)+V(I I I) \\
& V(I I)+V(I V)=2 V(I I I)
\end{aligned}
$$

Additional reactions that might be considered are the disproportionation of $U(V)$ or its reduction by either V(II) or V(III). No U(IV) is detected during the catalytic reaction, however; thus these reactions can be ignored. Making the usual steady-state approximation for the concentration of $U(V)$, we find that the rate law for reactions $3.19,3.20$, and 3.21 is

$$
-\frac{\mathrm{d}[\mathrm{V}(\mathrm{IV})]}{\mathrm{dt}}=\mathrm{k}_{21}[\mathrm{~V}(\mathrm{II})][\mathrm{V}(\mathrm{IV})]+\frac{\mathrm{k}_{19}[\mathrm{~V}(\mathrm{II})][\mathrm{U}(\mathrm{VI})]_{\mathrm{T}}}{1+\mathrm{k}_{19}[\mathrm{~V}(\mathrm{II})] /\left(\mathrm{k}_{20}[\mathrm{~V}(\mathrm{IV})]\right)}
$$

where $[\mathrm{U}(\mathrm{VI})]_{\mathrm{T}}$ is the total concentration of $\mathrm{U}(\mathrm{VI})$ added.

If the initial concentration of $\mathrm{V}(\mathrm{II})$ is approximately equal to that of $\mathrm{V}(\mathrm{IV})$, or if $\mathrm{k}_{\mathrm{I} g}[\mathrm{~V}(\mathrm{II})]$ is much smaller than $\mathrm{k}_{20}[\mathrm{~V}(\mathrm{IV})]$, the denominator term in $\mathrm{Eq} .3 .22$ will be essentially constant, and an apparent rate constant, $k^{\prime}=k_{19}\left\{1+k_{19}[V(I I)] /\right.$ $\left.\left(\mathrm{k}_{20}[\mathrm{~V}(\mathrm{IV})]\right)\right\}^{-1}$, can be defined.

The reaction was followed spectrophotometrically at $760 \mathrm{~nm}$ where V(IV) is the predominant absorbing species and the data were in good agreement with the rate law, Eq. 3.22, written in terms of $\mathrm{k}^{\prime}$. Values for $\mathrm{k}_{21}$ were taken from work on the uncatalyzed reaction, and consistent values for $\mathrm{k}^{\prime}$ were found over a 20 -fold change in [U(VI)], from $5 \times 10^{-5} M$ to $10^{-3} M$, and V(III) concentrations up to $10^{-2} M$. However, varying the initial $[\mathrm{V}(\mathrm{IV})] /[\mathrm{V}(\mathrm{II})]$ ratio from 1.1 to 5.5 caused a $4 \%$ increase in the apparent value for $\mathrm{k}^{\prime}$. This is outside the experimental error and suggests that $\mathrm{k}_{20}[\mathrm{~V}(\mathrm{IV})]$ is not much greater than $\mathrm{k}_{19}[\mathrm{~V}(\mathrm{II})]$. The observed effect is consistent with $\mathrm{k}_{20} / \mathrm{k}_{19} \approx 20$.

Rate constants were determined at hydrogen-ion concentrations from $0.05 \mathrm{M}$ to $2.0 \mathrm{M}$ and at temperatures from 0.6 to $36.8^{\circ} \mathrm{C}$. That the rate constant, $\mathrm{k}_{19}$, is essentially independent of the hydrogen-ion concentration shows that the principal net activation process is

$$
\mathrm{V}^{2+}+\mathrm{UO}_{2}^{2+}=\left[\mathrm{V} \cdot \mathrm{UO}_{2}^{4+}\right]^{*}
$$

The temperature dependence of $\mathrm{k}_{19}$ leads to $\Delta \mathrm{H}^{*}=30 \pm 0.4 \mathrm{~kJ} / \mathrm{mol}$ and $\Delta \mathrm{S}^{*}=$ $-110 \pm 2 \mathrm{~J} / \mathrm{mol} \cdot \mathrm{K}$. 
The uranyl ion has also been shown to catalyze the Fe(III)-V(III) (Ref. 51), the $\mathrm{Fe}(\mathrm{III})-\mathrm{Np}$ (III) (Ref. 12), and the oxygen-ascorbic acid ${ }^{52}$ reactions. The last reaction is of a different type, however, since U(V) is apparently not involved.

THE Np(VII)-Hg(I) 2 REACTION

Neptunium in the +7 state is a very powerful oxidizing agent in acid solutions but reacts slowly with water under these conditions. ${ }^{24,53}$ Reducing agents that react more slowly than water are difficult to study, but a variety of faster ones has been examined. The reactions between $\mathrm{Np}$ (VII) and the one-electron reducing agents $\mathrm{Ag}^{+}$, $\mathrm{Ce}^{3+}, \mathrm{Co}^{2+}$, and $\mathrm{NpO}_{2}^{+}$are all too rapid for convenient measurement. The oxidation of $\mathrm{Tl}^{+}$(Ref. 54) or $\mathrm{Hg}_{2}^{2+}$ is readily measurable, however. Because of its many interesting features, the $\mathrm{Hg}_{2}^{2+}$ reaction ${ }^{55}$ is discussed in detail.

Solutions of $\mathrm{Np}$ (VII) in $1 M \mathrm{NaOH}$ were prepared electrolytically by use of a platinum gauze anode with a current density of about $12 \mathrm{~A} / \mathrm{m}^{2}$ (Ref. 56). Solutions of $\mathrm{Hg}(\mathrm{I})_{2}$, defined as $\mathrm{Hg}_{2}^{2+}$ plus any hydrolyzed species, were prepared by reducing recrystallized $\mathrm{Hg}\left(\mathrm{ClO}_{4}\right)_{2}$ with metallic mercury and then adding a small excess of $\mathrm{Hg}(\mathrm{II})$, presumably to remove suspended or colloidal $\mathrm{Hg}^{0}$. The rate experiments were started by injecting samples of the alkaline $\mathrm{Np}$ (VII) solution into acidic solutions of the other reactants. The heat of neutralization was compensated by precooling the $\mathrm{Np}$ (VII) solution. The stoichiometry is given by

$$
2 \mathrm{~Np}(\mathrm{VII})+\mathrm{Hg}_{2}^{2+}=2 \mathrm{~Np}(\mathrm{VI})+2 \mathrm{Hg}^{2+}
$$

In six separate measurements the consumption ratio, $\Delta[\mathrm{Np}(\mathrm{VII})] / \Delta\left[\mathrm{Hg}(\mathrm{I})_{2}\right]$, was found to be $2.001 \pm 0.038$.

Rates were followed spectrophotometrically at $440 \mathrm{~nm}$, where $\mathrm{Np}$ (VII) absorbs strongly. First-power dependences were found for both $\mathrm{Hg}(\mathrm{I})_{2}$ and $\mathrm{Np}(\mathrm{VII})$ in experiments in which the initial concentration ranges were 5.9 to $23.7 \times 10^{-4} \mathrm{M}$ and 0.63 to $13.3 \times 10^{-4} \mathrm{M}$, respectively. The concentration of $\mathrm{Hg}(\mathrm{II})$ was without effect from $1.2 \times 10^{-3} \mathrm{M}$ to $3.9 \times 10^{-2} \mathrm{M}$. Thus $\mathrm{Np}$ (VII) is like the other strong oxidizing agents $\mathrm{Ag}(\mathrm{II})$ and $\mathrm{Co}(\mathrm{III})$ in that inhibition by $\mathrm{Hg}(\mathrm{II})$ is not observed. By contrast, inhibition is observed when Mn(III) and Tl(III) are used. ${ }^{5}$

The hydrogen-ion dependence of the apparent second-order rate constant is linear in the range $0.08 M$ to $0.94 M$ at constant ionic strength, made up with $\mathrm{LiClO}_{4}$. Thus the rate law can be written

$$
-\frac{\mathrm{d}[\mathrm{Np}(\mathrm{VII})]}{\mathrm{dt}}=2\left(\mathrm{k}_{0}+\mathrm{k}_{1}\left[\mathrm{H}^{+}\right]\right)[\mathrm{Np}(\mathrm{VII})]\left[\mathrm{Hg}(\mathrm{I})_{2}\right]
$$


This result indicates parallel rate-determining steps with the two net activation processes given in Table 3.5 .

The rates of the reaction were studied as a function of the hydrogen-ion concentration over a $33^{\circ}$ temperature interval (between 2 and $35^{\circ} \mathrm{C}$ ). We have used the combined hydrogen-ion- and temperature-dependence data to determine the best values for the thermodynamic quantities of activation for the two net activation processes. The results, which are in good agreement with the published activation energies, are given in Table 3.5 .

Table 3.5

NET ACTIVATION PROCESSES AND THERMODYNAMIC QUANTITIES OF ACTIVATION
FOR THE Np(VII)-Hg(I)

$\dagger$ Values are for $25^{\circ} \mathrm{C}$ and $\mu=1.0 \mathrm{M}\left(\mathrm{LiClO}_{4}\right)$.

$\$$ Values were calculated under the assumption that the overall rate is twice that of the rate-determining step.

$\S \mathrm{n}$ is the unknown charge on the $\mathrm{Np}$ (VII) species in acid solution.

Since the stoichiometry of the rate-determining steps is not the same as for the overall reaction (Eq. 3.24), a reactive intermediate must be involved. Plausible mechanisms, without regard to hydrogen ions, are

$$
\begin{aligned}
& \mathrm{Np}(\mathrm{VII})+\mathrm{Hg}(\mathrm{I})_{2}=\mathrm{Np}(\mathrm{VI})+\mathrm{Hg}(\mathrm{II})+\mathrm{Hg}(\mathrm{I}) \quad \text { (rate determining) } \\
& \mathrm{Np}(\mathrm{VII})+\mathrm{Hg}(\mathrm{I})=\mathrm{Np}(\mathrm{VI})+\mathrm{Hg}(\mathrm{II}) \quad \text { (rapid) }
\end{aligned}
$$

Or

$$
\begin{aligned}
& \mathrm{Np}(\mathrm{VII})+\mathrm{Hg}(\mathrm{I})_{2}=\mathrm{Np}(\mathrm{V})+2 \mathrm{Hg}(\mathrm{II}) \quad \text { (rate de termining) } \\
& \mathrm{Np}(\mathrm{VII})+\mathrm{Np}(\mathrm{V})=2 \mathrm{~Np}(\mathrm{VI}) \quad \text { (rapid) }
\end{aligned}
$$

For either of these mechanisms, the rate of disappearance of $\mathrm{Np}$ (VII) is twice that of the rate-determining step. It is possible, however, that the monomeric $\mathrm{Hg}$ (I) produced in reaction 3.26 will dimerize, in which case the overall rate will equal that of the 
rate-determining step. This ambiguity introduces an uncertainty of a factor of 2 into the values for the rate constants for the rate-determining steps and a corresponding uncertainty into the values for $\Delta \mathrm{G}^{*}$ and $\Delta \mathrm{S}^{*}$. The values in Table 3.5 are based on the assumption that $\mathrm{Np}$ (VII) is consumed in a rapid reaction after the rate-determining step. If $\mathrm{Np}$ (VII) is not consumed in this way, the $\Delta \mathrm{G}^{*}$ values in the table should be decreased by $1.72 \mathrm{~kJ} / \mathrm{mol}$ and the $\Delta \mathrm{S}^{*}$ values increased by $5.77 \mathrm{~J} / \mathrm{mol} \cdot \mathrm{K}$.

For the analogous oxidation of $\mathrm{Tl}(\mathrm{I})$ by $\mathrm{Np}$ (VII), the predominant term in the rate law is first power in $\left[\mathrm{H}^{+}\right]$(Ref. 55). The corresponding net activation process is $\mathrm{Np}(\mathrm{VII})+\mathrm{Tl}^{+}+\mathrm{H}^{+}=\left[^{*}\right]^{\mathrm{n}+\overline{2}}$, for which $\Delta \mathrm{H}^{*}=29.0 \pm 0.8 \mathrm{~kJ} / \mathrm{mol}$ and $\Delta \mathrm{S}^{*}=-142 \pm 3$ $\mathrm{J} / \mathrm{mol} \cdot \mathrm{K}$. These are quite close to the corresponding values for the $\mathrm{Hg}(\mathrm{I})_{2}$ reaction. This agreement may imply that the energetics for the hydrogen-ion-dependent path are relatively insensitive to the nature of the reductant.

Although the charge, $n$, on $N p(V I I)$ in acid solution has not been determined, the effect of ionic strength on the $\mathrm{Np}$ (VII) $-\mathrm{Hg}_{2}^{2+}$ reaction indicates that its sign is positive. The rate increases with increasing ionic strength, and, in $0.09 M \mathrm{HClO}_{4}$ solutions up to $\mu=3.7 M$ with $\mathrm{LiClO}_{4}$, the data are consistent with an extended Debye-Hückel equation (Eq. 7.1) for any value of $\mathrm{n}$ from +1 to +3 .

The rate law for the $\mathrm{Np}(\mathrm{VI})-\mathrm{H}_{2} \mathrm{O}_{2}$ reaction ${ }^{8}$ is more complicated than the rate laws discussed previously and gives evidence for a reactive intermediate and an inhibiting back reaction.

The net reaction was found to be

$$
2 \mathrm{NpO}_{2}^{2+}+\mathrm{H}_{2} \mathrm{O}_{2}=2 \mathrm{NpO}_{2}^{+}+2 \mathrm{H}^{+}+\mathrm{O}_{2}
$$

As long as the initial $[\mathrm{Np}(\mathrm{VI})] /\left[\mathrm{H}_{2} \mathrm{O}_{2}\right]$ ratio was greater than 2 , no decomposition of $\mathrm{H}_{2} \mathrm{O}_{2}$ was detected. Because concentration-vs.-time data were not in accord with the integrated form of the second-order rate law, the kinetics were studied by use of initial rates. Adding $\mathrm{NpO}_{2}^{+}$was found to decrease the initial rates markedly. Graphs of $\left[\mathrm{NpO}_{2}^{2+}\right]\left[\mathrm{H}_{2} \mathrm{O}_{2}\right]\left[\mathrm{H}^{+}\right]^{-1}\left(\mathrm{~d}\left[\mathrm{NpO}_{2}^{+}\right] / \mathrm{dt}\right)^{-1}$ vs. $\left[\mathrm{NpO}_{2}^{+}\right]\left[\mathrm{NpO}_{2}^{2+}\right]^{-1}$ were found to be linear with positive intercepts. This shows the rate law to be

$$
\left(\frac{\mathrm{d}\left[\mathrm{NpO}_{2}^{+}\right]}{\mathrm{dt}}\right)_{0}=\frac{\mathrm{k}^{\prime}\left[\mathrm{NpO}_{2}^{2+}\right]_{0}\left[\mathrm{H}_{2} \mathrm{O}_{2}\right]_{0}\left[\mathrm{H}^{+}\right]_{0}^{-1}}{1+\mathrm{b}\left[\mathrm{NpO}_{2}^{+}\right]_{0}\left[\mathrm{NpO}_{2}^{2+}\right]_{0}^{-1}}
$$

Values for $\mathrm{k}^{\prime}$ and $\mathrm{b}$ were found to be $8.9 \mathrm{sec}^{-1}$ and 1.9 , respectively, at $25^{\circ} \mathrm{C}$ in $3 \mathrm{M}$ $(\mathrm{H}, \mathrm{Na}) \mathrm{ClO}_{4}$. The temperature dependences of the rate constants between 5 and $25^{\circ} \mathrm{C}$ give activation energies of $51.9 \pm 4.6$ and $-6.3 \pm 5.9 \mathrm{~kJ} / \mathrm{mol}$ for $\mathrm{k}^{\prime}$ and $\mathrm{b}$, respectively. 
The form of this rate law indicates consecutive reactions (Fig. 2.1, pattern 2-1), and rearranging Eq. 3.31 shows the compositions of the two activated complexes involved:

$$
\begin{aligned}
\left(\frac{\mathrm{d}\left[\mathrm{NpO}_{2}^{+}\right]}{\mathrm{dt}}\right)_{0}^{-1}=\left(\mathrm{k}^{\prime}\left[\mathrm{NpO}_{2}^{2+}\right]_{0}[\right. & {\left.\left[\mathrm{H}_{2} \mathrm{O}_{2}\right]_{0}\left[\mathrm{H}^{+}\right]_{0}^{-1}\right)^{-1} } \\
& +\left(\frac{\mathrm{k}^{\prime}}{\mathrm{b}}\left[\mathrm{NpO}_{2}^{2+}\right]_{0}^{2}\left[\mathrm{H}_{2} \mathrm{O}_{2}\right]_{0}\left[\mathrm{H}^{+}\right]_{0}^{-1}\left[\mathrm{NpO}_{2}^{+}\right]_{0}^{-1}\right)^{-1}
\end{aligned}
$$

Here the reciprocal of the rate is equal to the sum of the reciprocals of two terms, each of which corresponds to one of the activation processes. These are shown in Table 3.6 along with their activation parameters.

Table 3.6

NET ACTIVATION PROCESSES AND THERMODYNAMIC QUANTITIES OF ACTIVATION FOR THE $\mathrm{Np}(\mathrm{VI})-\mathrm{H}_{2} \mathrm{O}_{2}$ REACTION $\dagger$

\begin{tabular}{lccc}
\hline Net activation process & $\begin{array}{c}\Delta \mathrm{G}^{*}, \\
\mathbf{k J} / \mathrm{mol} \\
(\mathrm{kcal} / \mathrm{mol})\end{array}$ & $\begin{array}{c}\Delta \mathrm{H}^{*}, \\
\mathrm{~kJ} / \mathrm{mol} \\
(\mathrm{kcal} / \mathrm{mol})\end{array}$ & $\begin{array}{c}\Delta \mathrm{S}^{*}, \\
\mathbf{J} / \mathrm{mol} \cdot \mathbf{K} \\
(\mathrm{cal} / \mathrm{mol} \cdot \mathrm{deg})\end{array}$ \\
\hline $\mathrm{NpO}_{2}^{2+}+\mathrm{H}_{2} \mathrm{O}_{2}=\left[^{*}\right]^{1+}+\mathrm{H}^{+}$ & $\begin{array}{c}69.5 \pm 0.4 \\
(16.6 \pm 0.1)\end{array}$ & $\begin{array}{c}49.4 \pm 4.6 \\
(11.8 \pm 1.1)\end{array}$ & $\begin{array}{c}-67 \pm 15 \\
(-16.1 \pm 3.7)\end{array}$ \\
$2 \mathrm{NpO}_{2}^{2+}+\mathrm{H}_{2} \mathrm{O}_{2}=\left[^{*}\right]^{2+}+\mathrm{NpO}_{2}^{+}+\mathrm{H}^{+}$ & $\begin{array}{c}71.1 \pm 0.2 \\
(17.0 \pm 0.5)\end{array}$ & $\begin{array}{c}55.6 \pm 7.5 \\
(13.3 \pm 1.8)\end{array}$ & $-52 \pm 25$ \\
\hline
\end{tabular}

$\dagger$ Values are for $25^{\circ}$ and $\mu=3.0 \mathrm{M}$.

A plausible mechanism that involves the indicated activated complexes is

$$
\begin{aligned}
& \mathrm{NpO}_{2}^{2+}+\mathrm{H}_{2} \mathrm{O} \stackrel{\mathrm{K}_{33}}{=} \mathrm{NpO}_{2}(\mathrm{OH})^{+}+\mathrm{H}^{+} \quad \text { (rapid hydrolysis equilibrium) } \\
& \mathrm{NpO}_{2}(\mathrm{OH})^{+}+\mathrm{H}_{2} \mathrm{O}_{2} \stackrel{\mathrm{K}_{34}}{\rightleftharpoons} \mathrm{NpO}_{2-34}^{+}+\mathrm{HO}_{2}+\mathrm{H}_{2} \mathrm{O} \\
& \mathrm{NpO}_{2}^{2+}+\mathrm{HO}_{2} \stackrel{\mathrm{k}_{35}}{=} \mathrm{NpO}_{2}^{+}+\mathrm{O}_{2}+\mathrm{H}^{+}
\end{aligned}
$$

If the usual steady-state approximation is made for the radical intermediate, $\mathrm{HO}_{2}$, this scheme leads to the rate law, Eq. 3.31 , where $k^{\prime}=2 k_{34} K_{33}$ and $b=k_{-3} / k_{35}$. Since $\mathrm{K}_{33}$ is about $10^{-5} M$ to $10^{-6} M, \mathrm{k}_{34}$ is about $10^{6} M^{-1} \mathrm{sec}^{-1}$.

The kinetically equivalent mechanism in which reactions 3.33 and 3.34 are replaced by

$$
\mathrm{H}_{2} \mathrm{O}_{2} \stackrel{\mathrm{K}_{33}}{=} \mathrm{H}^{+}+\mathrm{HO}_{2}^{-}
$$


and

$$
\mathrm{NpO}_{2}^{2+}+\mathrm{HO}_{2}^{-} \underset{\mathrm{k}_{-34 \mathrm{a}}}{\stackrel{\mathrm{k}_{3.4} \mathrm{a}}{\rightleftharpoons}} \mathrm{NpO}_{2}^{+}+\mathrm{HO}_{2}
$$

can be rejected because the equilibrium concentration $\mathrm{HO}_{2}^{-}$is too low. The acid dissociation constant for $\mathrm{H}_{2} \mathrm{O}_{2}, \mathrm{~K}_{33 \mathrm{a}}$, is about $10^{-1}{ }^{1} M$ at $25^{\circ} \mathrm{C}$ and $\mu=3 M$ (Ref. 59); thus $\mathrm{k}_{34 \mathrm{a}}=8.9 /\left(2 \times 10^{-11}\right)=4.4 \times 10^{11} \mathrm{M}^{-1} \mathrm{sec}^{-1}$ and is probably about $3 \times 10^{12}$ at $\mu=0$. Since this value is about 100 times larger than the diffusion-controlled limit, we can conclude that this alternate mechanism is unsatisfactory.

The analogous reduction of $\mathrm{Pu}(\mathrm{VI})$ has been investigated. ${ }^{60}$ Inhibition by $\mathrm{Pu}(\mathrm{V})$ was considered but was not explicitly studied. Some of the concentration-vs.-time curves show decreases in the apparent second-order rate constants as the reaction proceeds, however. The reported rate law for initial rates is

$$
-\frac{\mathrm{d}\left[\mathrm{PuO}_{2}^{2+}\right]}{\mathrm{dt}}=6.3 \times 10^{-3}\left[\mathrm{PuO}_{2}^{2+}\right]\left[\mathrm{H}_{2} \mathrm{O}_{2}\right]\left[\mathrm{H}^{+}\right]^{-1} M \mathrm{sec}^{-1}
$$

with an activation energy of $50 \pm 4 \mathrm{~kJ} / \mathrm{mol}$. Thus, for the net activation process studied, $\mathrm{PuO}_{2}^{2+}+\mathrm{H}_{2} \mathrm{O}_{2}=\left[{ }^{*}\right]^{+}+\mathrm{H}^{+}, \Delta \mathrm{G}^{*}=86 \mathrm{~kJ} / \mathrm{mol}, \Delta \mathrm{H}^{*}=48.4 \mathrm{~kJ} / \mathrm{mol}$, and $\Delta \mathrm{S}^{*}=$ $-125 \mathrm{~J} / \mathrm{mol} \cdot \mathrm{K}$. These results show that the plutonium reaction is much slower, primarily because of the more negative entropy of activation. No explanation is readily apparent for the surprising difference between the $\Delta S^{*}$ values reported for the reactions of $\mathrm{NpO}_{2}^{2+}$ and of $\mathrm{PuO}_{2}^{2+}$.

The rate law of the $U(I V)-P u(V I)$ reaction ${ }^{61}$ provides evidence for consecutive rate-determining steps and a binuclear intermediate, the 2-1 pattern discussed in Sec. 2-3.

In acid solutions $\mathrm{U}(\mathrm{IV})$ is a strong enough reducing agent to reduce $\mathrm{Pu}(\mathrm{VI})$ all the way to $\mathrm{Pu}(\mathrm{III})$ (Table 2.1). In dilute solutions, however $\left[1.8 \times 10^{-4} \mathrm{MPu}\right.$ (VI) and $0.62 \times 10^{-4} M \mathrm{U}(\mathrm{VI})$ in $\left.1 M \mathrm{HClO}_{4}\right]$, about $96 \%$ of the $\mathrm{U}(\mathrm{IV})$ reacts according to

$$
2 \mathrm{Pu}(\mathrm{VI})+\mathrm{U}(\mathrm{IV})=2 \mathrm{Pu}(\mathrm{V})+\mathrm{U}(\mathrm{VI})
$$

The rest reacts according to

$$
2_{3} \mathrm{Pu}(\mathrm{VI})+\mathrm{U}(\mathrm{IV})=2 / 3 \mathrm{Pu}(\mathrm{III})+\mathrm{U}(\mathrm{VI})
$$

The reaction rates, studied by use of the $\mathrm{Pu}(\mathrm{VI})$ absorption peak at $830.2 \mathrm{~nm}$, were all in good agreement with the rate law: 


$$
-\frac{\mathrm{d}[\mathrm{Pu}(\mathrm{VI})]}{\mathrm{dt}}=2 \mathrm{k}^{\prime \prime}[\mathrm{Pu}(\mathrm{VI})][\mathrm{U}(\mathrm{IV})]
$$

at constant ionic strength, $\left[\mathrm{H}^{+}\right]$, and temperature. This rate law requires that the activated complexes be formed from one $\mathrm{Pu}(\mathrm{VI})$ and one U(IV). The mechanism, without regard to hydrogen ions, is probably

$$
\mathrm{Pu}(\mathrm{VI})+\mathrm{U}(\mathrm{IV})=\mathrm{Pu}(\mathrm{V})+\mathrm{U}(\mathrm{V})
$$

followed by the rapid reaction

$$
\mathrm{Pu}(\mathrm{VI})+\mathrm{U}(\mathrm{V})=\mathrm{Pu}(\mathrm{V})+\mathrm{U}(\mathrm{VI})
$$

The disproportionation of U(V)

$$
2 \mathrm{U}(\mathrm{V})=\mathrm{U}(\mathrm{IV})+\mathrm{U}(\mathrm{VI})
$$

is too slow to account for the disappearance of U(V). This can be shown by calculating the steady-state concentration of $U(V)$ required to make the rate of reaction 3.42 equal to the observed rate. If the mechanism were reaction 3.40 , followed by reaction 3.42 , the relative concentration of $U(V)$ under steady-state conditions would be given by

$$
\frac{[\mathrm{U}(\mathrm{V})]}{\{[\mathrm{Pu}(\mathrm{VI})][\mathrm{U}(\mathrm{IV})]\}^{1 / 2}}=\left(\frac{\mathrm{k}_{40}}{2 \mathrm{k}_{42}}\right)^{1 / 2}
$$

In $0.1 M \mathrm{H}^{+}$at $25^{\circ} \mathrm{C}$ and $\mu=2 M, \mathrm{k}_{40}$ is approximately equal to $70 \mathrm{M}^{-1} \sec ^{-1}$ and $2 \mathrm{k}_{42}$ is approximately equal to $50 \mathrm{M}^{-1} \mathrm{sec}^{-1}$ (Ref. 20); thus the relative concentration of U(V) would be about 1.2. Such a large steady-state concentration could not be reached quickly enough for second-order kinetics to be observed. Thus the disproportionation of $U(V)$ will be unimportant with respect to its reaction with $\mathrm{Pu}(\mathrm{VI})$. The factor of 2 in Eq. 3.39 reflects the supposition that two $\mathrm{Pu}(\mathrm{VI})$ ions are consumed each time reaction 3.40 occurs.

The hydrogen-ion dependence was determined at four temperatures in $2 M$ $(\mathrm{H}, \mathrm{Li}) \mathrm{ClO}_{4}$ solutions from $0.1 \mathrm{M}$ to $1.5 \mathrm{M} \mathrm{H}^{+}$. In this range $\mathrm{U}(\mathrm{IV})$ hydrolyzes, but $\mathrm{Pu}(\mathrm{VI})$ does not. Thus $[\mathrm{U}(\mathrm{IV})]$ is equal to $\left[\mathrm{U}^{4+}\right]\left\{1+\left(\mathrm{K} /\left[\mathrm{H}^{+}\right]\right)\right\}$and $[\mathrm{Pu}(\mathrm{VI})]$ is equal to $\left[\mathrm{PuO}_{2}^{2+}\right]$, where $\mathrm{K}$ is the first hydrolysis constant for $\mathrm{U}(\mathrm{IV})$. Thus, in terms of species actually present in the solution, the rate law in Eq. 3.39 becomes

$$
-\frac{\mathrm{d}[\mathrm{Pu}(\mathrm{VI})]}{\mathrm{dt}}=2 \mathrm{k}^{\prime \prime}\left(1+\frac{\mathrm{K}}{\left[\mathrm{H}^{+}\right]}\right)\left[\mathrm{PuO}_{2}^{2+}\right]\left[\mathrm{U}^{4+}\right]
$$


Graphs of $\log \left\{\mathrm{k}^{\prime \prime}\left(1+\mathrm{K} /\left[\mathrm{H}^{+}\right]\right)\right\}$vs. $\log \left[\mathrm{H}^{+}\right]$show small amounts of curvature. For the $25^{\circ} \mathrm{C}$ data the slopes are -1.03 and -1.27 at $0.1 M$ and $1.5 M \mathrm{H}^{+}$, respectively. This hydrogen-ion dependence suggests that the most important activated complex is formed with the prior loss of one $\mathrm{H}^{+}$and that a second activated complex, formed with the loss of two hydrogen ions may be involved also. The decrease in the apparent $\mathrm{H}^{+}$ dependence with decreasing $\left[\mathrm{H}^{+}\right]$is not consistent with parallel rate-determining steps but suggests consecutive reactions instead. Thus the rate law to be tested is that for a 2-1 pattern:

$$
-\frac{\mathrm{d}[\mathrm{Pu}(\mathrm{VI})]}{\mathrm{dt}}=\frac{2[\mathrm{Pu}(\mathrm{VI})][\mathrm{U}(\mathrm{IV})]}{1+\mathrm{K} /\left[\mathrm{H}^{+}\right]}\left(\frac{1}{\mathrm{k}_{1}\left[\mathrm{H}^{+}\right]^{-1}}+\frac{1}{\mathrm{k}_{2}\left[\mathrm{H}^{+}\right]^{-2}}\right)^{-1}
$$

The correctness of this rate law is confirmed by the linearity of graphs of $\left\{\mathrm{k}^{\prime \prime}\left(\left[\mathrm{H}^{+}\right]+\right.\right.$ $\mathrm{K})\}^{-1}$ vs. $\left[\mathrm{H}^{+}\right]$for the data at each temperature. The rate constants $\mathrm{k}_{1}$ and $\mathrm{k}_{2}$ are given by the reciprocals of the intercepts and slopes of the graphs. The possibility that the $k_{2}$ term in the rate law is due to medium effects must be considered. In Sec. 2-4 it was shown that medium effects can give rate laws of the same form as Eq. 3.45 and that the Harned parameter, $-\beta$, would be given by $\mathrm{k}_{1} / \mathrm{k}_{2}$. At $25^{\circ} \mathrm{C}$ the values of $\mathrm{k}_{1}$

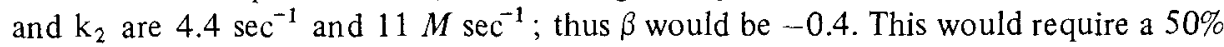
change in the pertinent activity-coefficient ratio on going from $1 M \mathrm{HClO}_{4}$ to $1 M$ $\mathrm{LiClO}_{4}$ and is unreasonably large. On this basis it is concluded that most, if not all, of the $\mathrm{k}_{2}$ term is due to an actual path and not merely to a medium effect.

Many detailed mechanisms are consistent with the rate law, Eq. 3.45. All require a binuclear intermediate that can react to give products or dissociate to give reactants at relative rates depending on the hydrogen-ion concentration. Perhaps the simplest such mechanism is

$$
\begin{aligned}
& \mathrm{U}^{4+}+\mathrm{H}_{2} \mathrm{O}=\mathrm{UOH}^{3+}+\mathrm{H}^{+} \quad \text { (rapid equilibrium) } \\
& \mathrm{UOH}^{3+}+\mathrm{PuO}_{2}^{2+} \rightleftharpoons \mathrm{HOUOPuO}^{5+} \quad \text { (rate de termining, reversible) } \\
& \mathrm{HOUOPuO}^{5+}=\mathrm{OUOPuO}^{4+}+\mathrm{H}^{+} \quad \text { (rapid equilibrium) } \\
& \text { OUOPuO }{ }^{4+}+\mathrm{H}_{2} \mathrm{O}=\mathrm{UO}_{2}^{+}+\mathrm{PuO}_{2}^{+}+2 \mathrm{H}^{+} \quad \text { (rate determining) }
\end{aligned}
$$

The binuclear intermediate, formed in the second step of this mechanism, must be an inner-sphere complex because its rate of formation is relatively low.

The two net activation processes required by the rate law, Eq. 3.45, do not depend on the details of the mechanism. The activation parameters, $\Delta \mathrm{G}^{*}, \Delta \mathrm{H}^{*}$, and $\Delta \mathrm{S}^{*}$, for these processes were determined from a simultaneous treatment of the hydrogen-ion and temperature data. The results are listed in Table 3.7. 
Table 3.7

NET ACTIVATION PROCESSES AND THERMODYNAMIC QUANTITIES OF ACTIVATION FOR THE U(IV)-Pu(VI) REACTION $\dagger$

\begin{tabular}{cccc}
\hline Net activation process & $\begin{array}{c}\Delta \mathrm{G}^{*}, \\
\mathbf{k J} / \mathbf{m o l} \\
(\mathrm{kcal} / \mathrm{mol})\end{array}$ & $\begin{array}{c}\Delta \mathrm{H}^{*}, \\
\mathrm{~kJ} / \mathrm{mol} \\
(\mathrm{kcal} / \mathrm{mol})\end{array}$ & $\begin{array}{c}\Delta \mathbf{S}^{*}, \\
\mathbf{J} / \mathbf{m o l} \cdot \mathbf{K} \\
(\mathbf{c a l} / \mathbf{m o l} \cdot \mathbf{d e g})\end{array}$ \\
\hline $\mathrm{U}^{4+}+\mathrm{PuO}_{2}^{2+}+\mathrm{H}_{2} \mathrm{O}=\left[{ }^{*}\right]^{5+}+\mathrm{H}^{+}$ & 69.33 & $73.8 \pm 0.5$ & $15 \pm 2$ \\
$\mathrm{U}^{4+}+\mathrm{PuO}_{2}^{2+}+\mathrm{H}_{2} \mathrm{O}=\left[{ }^{*}\right]^{4+}+2 \mathrm{H}^{+}$ & $(16.57)$ & $(17.6 \pm 0.1)$ & $(3.6 \pm 0.4)$ \\
& 67.07 & $89.2 \pm 1.3$ & $74 \pm 5$ \\
& $(16.03)$ & $(21.3 \pm 0.3)$ & $(17.8 \pm 1.3)$ \\
\hline
\end{tabular}

$\dagger$ Values are for $25^{\circ} \mathrm{C}$ and $\mu=2.0 \mathrm{M}$.

3-9

THE Pu(VI)-Fe(II) REACTION 62

The $\mathrm{Pu}(\mathrm{VI})-\mathrm{Fe}(\mathrm{II})$ reaction illustrates that even a very simple reaction can have a very complicated rate law and mechanism. The data are consistent with either of the 3-1 patterns of paths (Fig. 2.1).

When $\mathrm{Fe}(\mathrm{II})$ is added to an excess of $\mathrm{Pu}(\mathrm{VI})$, the predominant reaction is

$$
\mathrm{PuO}_{2}^{2+}+\mathrm{Fe}^{2+}=\mathrm{PuO}_{2}^{+}+\mathrm{Fe}^{3+}
$$

Using a $60 \%$ excess of $\mathrm{Pu}(\mathrm{VI})$, we found that the number of moles of $\mathrm{Pu}(\mathrm{VI})$ reduced per mole of $\mathrm{Fe}(\mathrm{II})$ oxidized ranged from 0.92 to 1.01 as the acid concentration was varied from $2.0 \mathrm{M}$ to $0.05 \mathrm{M}$ at constant ionic strength. However, Fe(II) is capable of reducing plutonium all the way to $\mathrm{Pu}(\mathrm{III})$, and, with excess $\mathrm{Fe}(\mathrm{II})$, we observe appreciable amounts of $\mathrm{Pu}(\mathrm{IV})$. The additional reactions that are important are

$$
\begin{aligned}
\mathrm{PuO}_{2}^{+}+\mathrm{Fe}^{2+}+4 \mathrm{H}^{+} & =\mathrm{Pu}^{4+}+\mathrm{Fe}^{3+}+2 \mathrm{H}_{2} \mathrm{O} \\
\mathrm{Pu}^{4+}+\mathrm{Fe}^{2+} & =\mathrm{Pu}^{3+}+\mathrm{Fe}^{3+}
\end{aligned}
$$

The rate of reaction 3.46 was determined in stirred, thermostated absorption cells. The $\mathrm{Pu}(\mathrm{VI})$ band at $830.3 \mathrm{~nm}$ was used to determine the extent of reaction vs. time. The rate law with excess $\mathrm{Pu}(\mathrm{VI})$ and at constant hydrogen-ion concentration was found to be

$$
-\frac{\mathrm{d}\left[\mathrm{PuO}_{2}^{2+}\right]}{\mathrm{dt}}=\mathrm{k}^{\prime}\left[\mathrm{PuO}_{2}^{2+}\right]\left[\mathrm{Fe}^{2+}\right]
$$


The metal-ion dependences shown in Eq. 3.49 were confirmed in experiments in which the plutonium and iron concentrations were varied by factors of 2 and 4, respectively, without significantly affecting the experimental value of $\mathrm{k}^{\prime}$.

The hydrogen-ion dependence, studied between $0.05 \mathrm{M}$ and $2.0 \mathrm{M}$ at constant ionic strength, was found to be quite complicated. The simplest function capable of reproducing the data satisfactorily is

$$
-\frac{\mathrm{d}\left[\mathrm{PuO}_{2}^{2+}\right]}{\mathrm{dt}}=\left\{\mathrm{A}+\left(\mathrm{B}+\mathrm{C}\left[\mathrm{H}^{+}\right]\right)^{-1}\right\}\left[\mathrm{PuO}_{2}^{2+}\right]\left[\mathrm{Fe}^{2+}\right]
$$

The fact that three parameters are required shows that there are three rate-determining steps and three important activated complexes. Referring to Fig. 2.1, we see that there are three possible patterns of paths to be considered. Since Eq. 3.50 does not reduce to the forms for either the 3-0 or the 3.2 patterns, these can be rejected. The equation can be reduced to forms corresponding to either of the 3-1 patterns, however.

Equation 3.50 is readily rearranged to give

$$
\begin{aligned}
\frac{\mathrm{d}\left[\mathrm{PuO}_{2}^{2+}\right]}{\mathrm{dt}}=\mathrm{A}\left[\mathrm{PuO}_{2}^{2+}\right]\left[\mathrm{Fe}^{2+}\right] & \\
& +\left(\frac{1}{\mathrm{~B}^{-1}\left[\mathrm{PuO}_{2}^{2+}\right]\left[\mathrm{Fe}^{2+}\right]}+\frac{1}{\mathrm{C}^{-1}\left[\mathrm{PuO}_{2}^{2+}\right]\left[\mathrm{Fe}^{2+}\right] /\left[\mathrm{H}^{+}\right]}\right)^{-1}
\end{aligned}
$$

which has the 3-1-b form. For this pattern parameter $A$ is associated with the path that leads directly to products, and the $\mathrm{B}$ and $\mathrm{C}$ terms involve the consecutive reactions. One of several possible mechanisms consistent with this pattern is

$$
\begin{gathered}
\mathrm{PuO}_{2}^{2+}+\mathrm{Fe}^{2+} \stackrel{\mathrm{k}_{52}}{=} \mathrm{PuO}_{2}^{+}+\mathrm{Fe}^{3+} \\
\mathrm{Fe}^{2+}+\mathrm{H}_{2} \mathrm{O} \stackrel{\mathrm{K}_{53}}{=} \mathrm{FeOH}^{+}+\mathrm{H}^{+} \\
\mathrm{PuO}_{2}^{2+}+\mathrm{FeOH}^{+} \stackrel{\mathrm{k}_{\mathrm{k}_{4}}}{\rightleftharpoons} \mathrm{PuO}_{2} \cdot \mathrm{Fe} \cdot \mathrm{OH}^{3+} \\
\mathrm{H}^{+}+\mathrm{PuO}_{2} \cdot \mathrm{Fe} \cdot \mathrm{OH}^{3+} \stackrel{k_{55}}{=} \mathrm{PuO}_{2}^{+}+\mathrm{Fe}^{3+}
\end{gathered}
$$

It is obvious that the equilibrium hydrolysis of $\mathrm{PuO}_{2}^{2+}$ instead of $\mathrm{Fe}^{2+}$ would be equally acceptable. Note also that the intermediate could just as well be formed without the loss of $\mathrm{H}^{+}$but that it hydrolyzes before reaction to products. This alternative corresponds to the mirror image of the pattern given by Eqs. 3.52 to 3.55 .

Equation 3.50 can also be rearranged to give 


$$
\begin{array}{r}
\frac{\mathrm{d}\left[\mathrm{PuO}_{2}^{2+}\right]}{\mathrm{dt}}=\left\{\frac{1}{\mathrm{~A}(1+\mathrm{AB})\left[\mathrm{PuO}_{2}^{2+}\right]\left[\mathrm{Fe}^{2+}\right]+(1+\mathrm{AB})^{2} \mathrm{C}^{-1}\left[\mathrm{PuO}_{2}^{2+}\right]\left[\mathrm{Fe}^{2+}\right] /\left[\mathrm{H}^{+}\right]}\right. \\
\left.+\frac{1}{(1+\mathrm{AB}) \mathrm{B}^{-1}\left[\mathrm{PuO}_{2}^{2+}\right]\left[\mathrm{Fe}^{2+}\right]}\right\}^{-1}
\end{array}
$$

In this form the rate law corresponds to pattern 3-1-a. The activated complexes involved in this pattern have the same compositions as before, but the effective rate constants for the formation of these complexes are not the same. This shows that although the activation parameters, $\mathrm{k}, \Delta \mathrm{G}^{*}, \Delta \mathrm{H}^{*}$, and $\Delta \mathrm{S}^{*}$, do not depend on the detailed mechanism for a given pattern of paths, they can depend on the pattern. The activation parameters for the $\mathrm{Pu}(\mathrm{VI})-\mathrm{Fe}(\mathrm{II})$ reaction calculated for the two patterns are compared in Table 3.8 .

The nature of the activated complexes indicated in Table 3.8 is unclear, but some limited conclusions can be reached. For either pattern the activated complexes in processes (2) and (3) in the table are formed sequentially and involve the formation or disappearance of a metastable intermediate. The transfer of the electron may occur either during the formation of the intermediate or during its reaction to give products. Thus it is unknown which of the two activated complexes is for the substitution reaction and which is for the redox reaction. The redox process is almost certainly inner sphere, however, because the binuclear intermediate is the immediate product (or reactant). By the same reasoning, the activated complex in process (1) is for an outer-sphere redox reaction if the pattern is $3-1-b$ but is for either a substitution reaction or an inner-sphere reaction if the pattern is 3-1-a.

\section{3-10}

\section{THE Cr(II)-Np(V) REACTION ${ }^{63}$}

The $\mathrm{Cr}(\mathrm{II})-\mathrm{Np}(\mathrm{V})$ reaction illustrates the complexities that may arise when competitive-consecutive reactions have rate constants such that the steady-state approximation cannot be applied. It also illustrates the use of ${ }^{18} \mathrm{O}$ to prove that the mechanism is predominantly inner sphere.

The reaction was carried out in $0.2 \mathrm{M}(\mathrm{H}, \mathrm{Li}) \mathrm{ClO}_{4}$ solutions with an excess of $\mathrm{Np}(\mathrm{V})$. The rate of appearance of $\mathrm{Np}$ (IV), which was followed spectrophotometrically at $732 \mathrm{~nm}$, did not adhere to second-order kinetics. In addition, examination at 276 $\mathrm{nm}$ showed the formation of appreciable concentrations of $\mathrm{Np}$ (III). For example, in $0.1 \mathrm{M} \mathrm{HClO}_{4}$ with an initial reactant ratio of $[\mathrm{Np}(\mathrm{V})] /[\mathrm{Cr}(\mathrm{II})]=4$, the product ratio $[\mathrm{Np}(\mathrm{III})] /[\mathrm{Np}(\mathrm{IV})]$ was 0.12 after $75 \%$ of the $\mathrm{Cr}(\mathrm{II})$ had been consumed. A similar experiment in $0.05 \mathrm{M} \mathrm{HClO}_{4}$ gave a product ratio of 0.48 . 
Table 3.8

NET ACTIVATION PROCESSES AND THERMODYNAMIC QUANTITIES OF ACTIVATION FOR THE Pu(VI)-Fe(II) REACTION $†$

\begin{tabular}{|c|c|c|c|c|c|c|}
\hline \multirow[b]{2}{*}{ Net activation process } & \multicolumn{3}{|c|}{ Pattern 3-1-a } & \multicolumn{3}{|c|}{ Pattern 3-1-b } \\
\hline & $\begin{array}{c}\Delta \mathrm{G}^{*} \\
\mathrm{~kJ} / \mathrm{mol} \\
(\mathrm{kcal} / \mathrm{mol})\end{array}$ & $\begin{array}{c}\Delta \mathrm{H}^{*} \\
\mathrm{~kJ} / \mathrm{mol} \\
(\mathrm{kcal} / \mathrm{mol})\end{array}$ & $\begin{array}{c}\Delta S^{*}, \\
\mathbf{J} / \mathrm{mol} \cdot \mathbf{K} \\
(\mathrm{cal} / \mathrm{mol} \cdot \operatorname{deg})\end{array}$ & $\begin{array}{c}\Delta \mathrm{G}^{*} \\
\mathrm{~kJ} / \mathrm{mol} \\
(\mathrm{kcal} / \mathrm{mol})\end{array}$ & $\begin{array}{c}\Delta \mathrm{H}^{*} \\
\mathrm{~kJ} / \mathrm{mol} \\
(\mathrm{kcal} / \mathrm{mol})\end{array}$ & $\begin{array}{c}\Delta \mathrm{S}^{*} \\
\mathrm{~J} / \mathrm{mol} \cdot \mathrm{K} \\
(\mathrm{cal} / \mathrm{mol} \cdot \mathrm{deg})\end{array}$ \\
\hline 1. $\mathrm{PuO}_{2}^{2+}+\mathrm{Fe}^{2+}=[*]^{4+}$ & $\begin{array}{c}55.4 \\
(13.25)\end{array}$ & $\begin{array}{c}16.0 \pm 0.8 \\
(3.83 \pm 0.2)\end{array}$ & $\begin{array}{c}-132 \pm 3 \\
(-31.6 \pm 0.7)\end{array}$ & $\begin{array}{c}55.9 \\
(13.36)\end{array}$ & $\begin{array}{c}20.5 \pm 0.8 \\
(4.91 \pm 0.18)\end{array}$ & $\begin{array}{c}-118 \pm 3 \\
(-28.3 \pm 0.6)\end{array}$ \\
\hline 2. $\mathrm{PuO}_{2}^{2+}+\mathrm{Fe}^{2+}=[*]^{4+}$ & $\begin{array}{c}51.6 \\
(12.34)\end{array}$ & $\begin{array}{c}33.3 \pm 1.3 \\
(7.95 \pm 0.31)\end{array}$ & $\begin{array}{c}-62 \pm 5 \\
(-14.7 \pm 1.1)\end{array}$ & $\begin{array}{c}52.0 \\
(12.44)\end{array}$ & $\begin{array}{c}39.0 \pm 1.9 \\
(9.31 \pm 0.46)\end{array}$ & $\begin{array}{c}-44 \pm 7 \\
(-10.5 \pm 1.6)\end{array}$ \\
\hline 3. $\mathrm{PuO}_{2}^{2+}+\mathrm{Fe}^{2+}+\mathrm{H}_{2} \mathrm{O}=\left[{ }^{*}\right]^{3+}+\mathrm{H}^{+}$ & $\begin{array}{l}55.6 \\
(13.28)\end{array}$ & $\begin{array}{c}36.2 \pm 2.2 \\
(8.66 \pm 0.52)\end{array}$ & $\begin{aligned}-65 & \pm 8 \\
(-15.5 & \pm 1.8)\end{aligned}$ & $\begin{array}{l}56.6 \\
(13.54)\end{array}$ & $\begin{aligned} 42.6 & \pm 2.0 \\
(10.17 & \pm 0.48)\end{aligned}$ & $\begin{array}{c}-47 \pm 7 \\
(11.3 \pm 1.7)\end{array}$ \\
\hline
\end{tabular}

$\dagger$ Values are for $25^{\circ} \mathrm{C}$ and $\mu=2 M\left(\mathrm{LiClO}_{4}\right)$. 
A plausible reaction sequence to explain the observations is

$$
\begin{aligned}
\mathrm{Np}(\mathrm{V})+\mathrm{Cr}(\mathrm{II}) & =\mathrm{Np}(\mathrm{IV})+\mathrm{Cr}(\mathrm{III}) \\
\mathrm{Np}(\mathrm{IV})+\mathrm{Cr}(\mathrm{II}) & =\mathrm{Np}(\mathrm{III})+\mathrm{Cr}(\mathrm{III}) \\
\mathrm{Np}(\mathrm{III})+\mathrm{Np}(\mathrm{V}) & =2 \mathrm{~Np}(\mathrm{IV})
\end{aligned}
$$

This scheme is similar to that proposed for the reduction of $\mathrm{Np}(\mathrm{V})$ by $\mathrm{V}(\mathrm{III})$, discussed in Sec. 3.4, but differs in that reaction 3.59 and the reverse of reaction 3.58 are relatively slow and appreciable concentrations of $\mathrm{Np}$ (III) build up. Since the usual steady-state approximation is not applicable, it is necessary to use two differential equations to describe the concentration changes that occur. These are

$$
\begin{aligned}
\frac{d x}{d t}=k_{57}(A-x-y)(B-x-2 y)-k_{58}(x)(B-x-2 y) & \\
& +2 k_{59}(A-x-y)(y)
\end{aligned}
$$

and

$$
\frac{d y}{d t}=k_{58}(x)(B-x-2 y)-k_{59}(A-x-y)(y)
$$

where $A$ and $B$ are the initial concentrations of $\mathrm{Np}(\mathrm{V})$ and $\mathrm{Cr}(\mathrm{II})$, respectively, and $\mathrm{x}$ and $y$ are the instantaneous concentrations of $N p(I V)$ and $N p(I I I)$, respectively. These differential equations cannot be solved in closed form but are readily solved by numerical methods.

In principle the concentration-vs.-time data could be used to determine all three rate constants, but more-accurate values for $k_{57}$ were obtained by using values for $k_{58}$ and $k_{59}$ which were determined in separate experiments. Values for $k_{5} 7$ which best reproduce the observed data were found by use of a computer program that couples a Runge-Kutta method for solving Eqs. 3.60 and 3.61 to a nonlinear least-squares program. 51

In this way values for $\mathrm{k}_{5} 7$ were determined for temperatures ranging from 5 to $25^{\circ} \mathrm{C}$ and for hydrogen-ion concentrations from $0.026 \mathrm{M}$ to $0.21 \mathrm{M}$, all at a constant ionic strength of $0.21 \mathrm{M}$ made up with $\mathrm{LiClO}_{4}$. In addition, $\mathrm{k}_{5} 7$ increases by a factor of 4.1 between ionic strengths of $0.11 \mathrm{M}$ and $1.01 \mathrm{M}$. The reaction is markedly catalyzed by sulfate; as little as $10^{-3} \mathrm{M}$ in $0.11 M \mathrm{HClO}_{4}$ at $17^{\circ} \mathrm{C}$ increases the rate by a factor of 4.7 .

Like the rates of most other reactions in which an actinide $\mathrm{AnO}_{2}^{+}$ion is reduced, the rate increases with increasing hydrogen-ion concentration. Graphs of $\log k_{57}$ vs. $\log \left[\mathrm{H}^{+}\right]$give the empirical expression $\mathrm{k}_{57}=\mathrm{k}^{\prime}\left[\mathrm{H}^{+}\right]^{\mathrm{n}}$, where the exponent varies from 0.76 to 0.86 depending on the temperature. This suggests that the major term in the rate law is first order in $\left[\mathrm{H}^{+}\right]$but that another term, due to an additional path or to a medium effect, is present also. Thus two rate laws were tested for consistency with the data: 


$$
\begin{aligned}
& \frac{\mathrm{d}[\mathrm{Np}(\mathrm{IV})]}{\mathrm{dt}}=\left(\mathrm{k}_{\mathrm{a}}+\mathrm{k}_{\mathrm{b}}\left[\mathrm{H}^{+}\right]\right)\left[\mathrm{NpO}_{2}^{+}\right]\left[\mathrm{Cr}^{2+}\right] \\
& \frac{\mathrm{d}[\mathrm{Np}(\mathrm{IV})]}{\mathrm{dt}}=\left(\mathrm{k}_{\mathrm{c}}\left[\mathrm{H}^{+}\right] \mathrm{e}^{\beta\left[\mathrm{H}^{+}\right]}\right)\left[\mathrm{NpO}_{2}^{+}\right]\left[\mathrm{Cr}^{2+}\right]
\end{aligned}
$$

All the hydrogen-ion- and temperature-dependence data were treated simultaneously to find the values of the heats and entropies of activation and the value of $\beta$ and its temperature coefficient which best reproduce the observed values of $k_{57}$. The results of these calculations are summarized in Table 3.9.

Table 3.9

ALTERNATE INTERPRETATIONS OF THE HYDROGEN-ION- AND TEMPERATUREDEPENDENCE DATA FOR THE Cr(II)-Np(V) REACTION $\dagger$

\begin{tabular}{lll}
\hline \multicolumn{1}{c}{ Parameter } & \multicolumn{1}{c}{ Rate law 3.62 } & \multicolumn{1}{c}{ Rate law 3.63 } \\
\hline $\begin{array}{l}\Delta \mathrm{H}^{*} \mathrm{~b} / \mathrm{c}, \mathrm{kJ} / \mathrm{mol}(\mathrm{kcal} / \mathrm{mol}) \\
\Delta \mathrm{S}^{*} \mathrm{~b} / \mathrm{c}, \mathrm{J} / \mathrm{mol} \cdot \mathrm{K}(\mathrm{cal} / \mathrm{mol} \cdot \mathrm{deg})\end{array}$ & $8 \pm 3(2.0 \pm 0.7)$ & $11 \pm 2(2.6 \pm 0.4)$ \\
$\Delta \mathrm{H}^{*} \mathrm{a}, \mathrm{kJ} / \mathrm{mol}(\mathrm{kcal} / \mathrm{mol})$ & $32 \pm 16(8 \pm 4)$ & $-149 \pm 6(-35.7 \pm 1.4)$ \\
$\Delta \mathrm{S}^{*} \mathrm{a}, \mathrm{J} / \mathrm{mol} \cdot \mathrm{K}(\mathrm{cal} / \mathrm{mol} \cdot \mathrm{deg})$ & $-116 \pm 54(-28 \pm 13)$ & \\
$\beta, M^{-1}$ & & $-1.45 \pm 0.32 \pm$ \\
$\begin{array}{l}\text { Root-mean-square } \\
\quad \text { deviation, } \%\end{array}$ & 8.1 & 9.1 \\
\hline
\end{tabular}

$\left\lceil\right.$ The original authors used six adjustable parameters: $\Delta H_{c}^{*}, \Delta S_{c}^{*}$, and a different value for $\beta$ for each of the four temperatures. This gives activation parameters very similar to those listed for rate law 3.63 and a root-mean-square deviation of about $9.5 \%$.

$\$$ Temperature dependence of $\beta$ is taken as zero because the least-squares best value is $0.0053 \pm$ $0.0345 \mathrm{deg}^{-1}$, which is not statistically significant.

It is seen that the activation parameters for the predominant term, first power in $\left[\mathrm{H}^{+}\right]$, do not depend significantly on which rate law is assumed. The rate law, Eq. 3.62, is preferred, however, because the value required for $\beta$ in the rate law, Eq. 3.63, is about 10 times the reasonable upper limit discussed in Sec. 2-4.

The exchange of oxygen between $\mathrm{NpO}_{2}^{+}$and $\mathrm{H}_{2} \mathrm{O}$ is fairly slow ${ }^{33}$ and between $\mathrm{Cr}\left(\mathrm{H}_{2} \mathrm{O}\right)_{6}^{3+}$ and solvent water is very slow. ${ }^{64}$ This means that it is possible to use ${ }^{18} \mathrm{O}$ tracer experiments to determine the fate of the coordinated oxygens when $\mathrm{NpO}_{2}^{+}$is reduced by $\mathrm{Cr}^{2+}$, as in Eq. 3.57, which can be rewritten in terms of the species present as

$$
\mathrm{NpO}_{2}^{+}+\mathrm{Cr}^{2+}(\mathrm{aq})+4 \mathrm{H}^{+}=\mathrm{Np}^{4+}+\mathrm{Cr}^{3+}(\mathrm{aq})+2 \mathrm{H}_{2} \mathrm{O}
$$

Dry $\mathrm{NpO}_{2} \mathrm{ClO}_{4}$ in which the ${ }^{18} \mathrm{O} /{ }^{16} \mathrm{O}$ ratio was about 0.01 was prepared, dissolved in a small amount of ordinary water, and injected into less than the stoichiometric 
amount of $\mathrm{Cr}^{2+}$ in dilute $\mathrm{HClO}_{4}$. The product $\mathrm{Cr}\left(\mathrm{H}_{2} \mathrm{O}\right)_{6}^{3+}$ was separated as $\mathrm{Cr}\left(\mathrm{H}_{2} \mathrm{O}\right)_{6} \mathrm{~F}_{3}$. The water was removed from this salt and equilibrated with $\mathrm{CO}_{2}$ for analysis using an isotope-ratio mass spectrometer. If the activated complex for reaction 3.64 is inner sphere, so that one of the neptunyl oxygens is coordinated to chromium, and if all the $\mathrm{Cr}^{3+}$ is produced by this reaction, then one-sixth of the water coordinated to the $\mathrm{Cr}(\mathrm{III})$ products will come from the $\mathrm{NpO}_{2}^{+}$. Two experiments in $1 M$ $\mathrm{HClO}_{4}$ gave values for the isotope ratio which were $0.90 \pm 0.08$ of that expected on this basis. A single experiment in $0.17 M \mathrm{HClO}_{4}$ gave a value only 0.68 of that expected. This low value is undoubtedly caused by the fact that, although reaction 3.58 is relatively unimportant in $1 M \mathrm{HClO}_{4}$, the hydrogen-ion dependences are such that the ratio $\mathrm{k}_{57} / \mathrm{k}_{58}$ is about 6.4 in $0.17 M \mathrm{HClO}_{4}$. Under these conditions an appreciable fraction of the $\mathrm{Cr}$ (III) is produced by reaction 3.58 .

\section{3-11}

\section{THE U(IV)-CI(III) REACTION 65}

The stoichiometry of the U(IV)-Cl(III) reaction is quite complicated. When $\mathrm{U}^{4+}$ and $\mathrm{HClO}_{2}$ are mixed, the ratio [Cl(III) $]_{\text {consumed/ }} /[\mathrm{U}(\mathrm{IV})]_{\text {consumed }}$ varies between 1.5 and 2.5 depending on the initial concentrations. ${ }^{66}$ With an appropriate scavenger, such as phenol, the ratio becomes 1.0 , however. These results are accounted for by the following reactions:

$$
\begin{gathered}
\mathrm{U}^{4+}+\mathrm{HClO}_{2}+\mathrm{H}_{2} \mathrm{O}=\mathrm{UO}_{2}^{2+}+\mathrm{HOCl}+2 \mathrm{H}^{+} \\
\mathrm{HOCl}+\mathrm{HClO}_{2}=\mathrm{Cl}_{2} \mathrm{O}_{2}+\mathrm{H}_{2} \mathrm{O}
\end{gathered}
$$

and

$$
\mathrm{Cl}_{2} \mathrm{O}_{2}+\mathrm{C}_{6} \mathrm{H}_{5} \mathrm{OH}=\mathrm{ClC}_{6} \mathrm{H}_{4} \mathrm{OH}+\mathrm{HClO}_{2}
$$

Separate experiments showed that reactions 3.66 and 3.67 are fast compared with 3.65 ; thus the net reaction is

$$
\mathrm{U}^{4+}+\mathrm{HClO}_{2}+\mathrm{C}_{6} \mathrm{H}_{5} \mathrm{OH}=\mathrm{UO}_{2}^{2+}+\mathrm{ClC}_{6} \mathrm{H}_{4} \mathrm{OH}+2 \mathrm{H}^{+}
$$

Second-order rate constants, determined spectrophotometrically at the U(IV) peak at $648 \mathrm{~nm}$, were found to be independent of initial phenol concentrations if these were greater than the initial U(IV) concentrations. Over wide ranges of reactant and hydrogen-ion concentrations the rate law was found to be

$$
-\frac{\mathrm{d}[\mathrm{U}(\mathrm{IV})]}{\mathrm{dt}}=\frac{\mathrm{k}[\mathrm{U}(\mathrm{IV})]\left[\mathrm{HClO}_{2}\right]\left[\mathrm{H}^{+}\right]^{-1}}{1+\mathrm{K}\left[\mathrm{HClO}_{2}\right]}
$$


Note that the total $\mathrm{Cl}(\mathrm{III})$ concentration is given by $[\mathrm{Cl}(\mathrm{III})]=\left[\mathrm{HClO}_{2}\right](1+$ $\mathrm{K}_{\mathrm{a}}\left[\mathrm{H}^{+}\right]^{-1}$ ), where $\mathrm{K}_{\mathrm{a}} \approx 0.03 M$ at $25^{\circ} \mathrm{C}$ and $\mu=2 M$. Thus, in acid solutions greater than about $0.1 M, \mathrm{Cl}(\mathrm{III})$ is predominan tly $\mathrm{HClO}_{2}$.

The denominator term in Eq. 3.69 suggests the possibility of consecutive reactions (pattern 2-1). Rearranging the equation gives

$$
\left(-\frac{\mathrm{d}[\mathrm{U}(\mathrm{IV})]}{\mathrm{dt}}\right)^{-1}=\frac{1}{\mathrm{k}[\mathrm{U}(\mathrm{IV})]\left[\mathrm{HClO}_{2}\right]\left[\mathrm{H}^{+}\right]^{-1}}+\frac{1}{\mathrm{kK}^{-1}[\mathrm{U}(\mathrm{IV})]\left[\mathrm{H}^{+}\right]^{-1}}
$$

This equation implies that one activated complex is made from $\mathrm{U}(\mathrm{IV})$ and $\mathrm{HClO}_{2}$ with the prior loss of one $\mathrm{H}^{+}$and that a second activated complex is made from only U(IV) with the loss of $\mathrm{H}^{+}$. Consistent with this, we would write

$$
\begin{gathered}
\mathrm{U}^{4+}+\mathrm{H}_{2} \mathrm{O} \stackrel{\mathrm{K}}{=} \mathrm{UOH}^{3+}+\mathrm{H}^{+} \quad \text { (rapid equilibrium) } \\
\mathrm{UOH}^{3+} \underset{\mathrm{k}_{72}}{\stackrel{\mathrm{k}_{72}}{\rightleftharpoons}}\left(\mathrm{UOH}^{3+}\right)_{*}^{*} \\
\left(\mathrm{UOH}^{3+}\right)_{*}^{*}+\mathrm{HClO}_{2} \stackrel{\mathrm{k}_{73}}{=} \mathrm{UO}_{2}^{2+}+\mathrm{H}^{+}+\mathrm{HOCl}
\end{gathered}
$$

where $\left(\mathrm{UOH}^{3+}\right)_{*}^{*}$ is a reactive form of $\mathrm{UOH}^{3+}$. Making the usual steady-state approximation with respect to its concentration, we readily derive the following rate law:

$$
-\frac{\mathrm{d}[\mathrm{U}(\mathrm{IV})]}{\mathrm{dt}}=\frac{\left(\mathrm{k}_{72} \mathrm{k}_{73} \mathrm{~K} / \mathrm{k}_{72}\right)[\mathrm{U}(\mathrm{IV})]\left[\mathrm{HClO}_{2}\right]\left[\mathrm{H}^{+}\right]^{-1}}{1+\left(\mathrm{k}_{73} / \mathrm{k}_{-72}\right)\left[\mathrm{HClO}_{2}\right]}
$$

which has the same form as Eq. 3.69, the observed rate law.

Before accepting this mechanism, which requires a "reactive form" of $\mathrm{UOH}^{3+}$, we should note that the two-term denominator in Eq. 3.69 can arise also from the formation of significant concentrations of a U(IV)-Cl(III) complex. Consider the following mechanism:

$$
\begin{array}{cc}
\mathrm{HClO}_{2} \stackrel{\mathrm{K}_{75}}{=} \mathrm{H}^{+}+\mathrm{ClO}_{2}^{-} & \text {(rapid equilibrium) } \\
\mathrm{U}^{4+}+\mathrm{HClO}_{2} \stackrel{\mathrm{K}_{76}}{=} \mathrm{UOClOH}^{4+} & \text { (rapid equilibrium) } \\
\mathrm{U}^{4+}+\mathrm{ClO}_{2}^{-} \stackrel{\mathrm{K}_{77}}{=} \text { products } & \text { (rate determining) }
\end{array}
$$

$\left[\mathrm{U}^{4+}\right]$ will equal $[\mathrm{U}(\mathrm{IV})]\left(1+\mathrm{K}_{76}\left[\mathrm{HClO}_{2}\right]\right)^{-1}$, and the rate law will be

$$
-\frac{\mathrm{d}[\mathrm{U}(\mathrm{IV})]}{\mathrm{dt}}=\mathrm{k}_{77} \mathrm{~K}_{75}[\mathrm{U}(\mathrm{IV})]\left[\mathrm{HClO}_{2}\right]\left[\mathrm{H}^{+}\right]^{-1}\left(1+\mathrm{K}_{76}\left[\mathrm{HClO}_{2}\right]\right)^{-1}
$$

again in agreement with the observed rate law. The fact that two radically different mechanisms lead to the same rate law illustrates the necessity of knowing the 
equilibria in a system before attempting a mechanistic interpretation. In this case a rapid increase in absorbance was observed at $360 \mathrm{~nm}$ when the reactants were mixed. This was probably a result of reaction 3.76 because, although $\mathrm{Cl}(\mathrm{III})$ is known to react with $\mathrm{U}(\mathrm{VI})$ to give a colored complex, only about $1 \%$ of the uranium used was in the form of the +6 oxidation state.

For either mechanism the principal net activation process is

$$
\mathrm{U}^{4+}+\mathrm{HClO}_{2}=[*]^{3+}+\mathrm{H}^{+}
$$

The more plausible second mechanism was assumed, and the temperature-dependence data were used to evaluate the activation parameters: $\Delta H^{*}=86.1 \pm 1.7 \mathrm{~kJ} / \mathrm{mol}$ and $\Delta \mathrm{S}^{*}=66.5 \pm 6.3 \mathrm{~J} / \mathrm{mol} \cdot \mathrm{K}$.

Further information about the mechanism was gained by the use of ${ }^{18} \mathrm{O}$-labeled $\mathrm{HClO}_{2}$. Efficient oxygen transfer to the product $\mathrm{UO}_{2}^{2+}$ was observed; an average of $0.76 \pm 0.04$ of an oxygen is transferred from the $\mathrm{HClO}_{2}$ reactant to the $\mathrm{UO}_{2}^{2+}$ product. This implies an inner-sphere activated complex and a two-electron oxidation of $\mathrm{U}^{4+}$ to $\mathrm{UO}_{2}^{2+}$ since the one-electron intermediate, $\mathrm{UO}_{2}^{+}$, exchanges oxygen rapidly with the solvent.

\section{3-12}

\section{THE U(IV)-Cr(VI) REACTION ${ }^{67}$}

The U(IV)-Cr(VI) reaction is particularly interesting because it shows how in certain circumstances we can learn more about a mechanism than is given by the rate law. If a reaction produces intermediates capable of reacting with substances other than the usual reactants or products, these reactions may provide important additional information. In the $\mathrm{U}(\mathrm{IV})-\mathrm{Cr}(\mathrm{VI})$ reaction, although $\mathrm{I}^{-}$reacts very slowly with $\mathrm{HCrO}_{4}^{-}$ and $I_{2}$ reacts very slowly with $U(I V)$, significant amounts of $I_{2}$ are formed if $I^{-}$is present during the reaction between U(IV) and $\mathrm{Cr}(\mathrm{VI})$. This is an example of an induced reaction; other such reactions involving $\mathrm{Cr}(\mathrm{VI})$ and $\mathrm{I}^{-}$are discussed in a review by Westheimer. ${ }^{68}$

In the absence of $\mathrm{I}^{-}$or other reducing agents, the stoichiometry of the U(IV) $-\mathrm{Cr}_{\mathrm{r}}$ (VI) reaction is just what would be expected on the basis of the potentials:

$$
3 \mathrm{U}(\mathrm{IV})+2 \mathrm{Cr}(\mathrm{VI})=3 \mathrm{U}(\mathrm{VI})+2 \mathrm{Cr}(\mathrm{III})
$$

In fact, standard volumetric methods of analysis are based on this reaction.

Important equilibria influencing the interpretation of the kinetics are the hydrolysis of U(IV),

$$
\mathrm{U}^{4+}+\mathrm{H}_{2} \mathrm{O}=\mathrm{UOH}^{3+}+\mathrm{H}^{+} \quad\left(\mathrm{K}_{81}=0.01 M\right)
$$


and the acid dissociation of $\mathrm{H}_{2} \mathrm{CrO}_{4}$,

$$
\mathrm{H}_{2} \mathrm{CrO}_{4}=\mathrm{H}^{+}+\mathrm{HCrO}_{4}^{-} \quad\left(\mathrm{K}_{82}=5.0 M\right)
$$

Other equilibria, such as $2 \mathrm{HCrO}_{4}^{-}=\mathrm{Cr}_{2} \mathrm{O}_{7}^{2-}+\mathrm{H}_{2} \mathrm{O}$ and $\mathrm{HCrO}_{4}^{-}=\mathrm{H}^{+}+\mathrm{CrO}_{4}^{2-}$, with equilibrium quotients of $98 \mathrm{M}^{-1}$ and $3 \times 10^{-7} \mathrm{M}$, respectively, are not important in the solutions studied.

The reaction is quite rapid, and the rates were studied spectrophotometrically with a commercial stopped-flow apparatus. $\dagger$

At a constant hydrogen-ion concentration, the rate law is

$$
\frac{\mathrm{d}[\mathrm{U}(\mathrm{IV})]}{\mathrm{dt}}=\mathrm{k}^{\prime \prime}[\mathrm{U}(\mathrm{IV})][\mathrm{Cr}(\mathrm{VI})]
$$

The second-order rate constant defined by this equation was determined over a wide range of $\left[\mathrm{H}^{+}\right]$(from $0.15 M$ to $2.99 M$ ) and was found to be given by

$$
\mathrm{k}^{\prime \prime}=\left(0.86+8.83\left[\mathrm{H}^{+}\right]^{-1}\right) \times 10^{4}\left(1+\frac{\mathrm{K}_{81}}{\left[\mathrm{H}^{+}\right]}\right)^{-1}\left(1+\frac{\left[\mathrm{H}^{+}\right]}{\mathrm{K}_{82}}\right)^{-1}
$$

The second and third terms are due to equilibria 3.81 and 3.82 and are relatively small because $\mathrm{K}_{82}>\left(\mathrm{H}^{+}\right]>\mathrm{K}_{81}$. This rate law shows that the principal net activation process is

$$
\mathrm{U}^{4+}+\mathrm{HCrO}_{4}^{-}=\left[{ }^{*}\right]^{2+}+\mathrm{H}^{+}
$$

The fact that the stoichiometry for the formation of the activated complex does not correspond to that for the overall reaction shows that one or more intermediates are involved in the reaction. After the rate-determining step, these intermediates must react rapidly with the original reactants or with themselves to complete the overall reaction. Since iodide reacts rapidly with $\mathrm{Cr}(\mathrm{V})$, one of the possible intermediates, a study of the formation of $\mathrm{I}_{2}$ gives additional information about the mechanism.

When the induction factor, the ratio (equivalents of $\mathrm{I}^{-}$oxidized)/(equivalents of U(IV) oxidized), was measured, it was found to depend on the $[\mathrm{U}(\mathrm{IV})] /\left[\mathrm{I}^{-}\right]$ratio. The induction factor approaches a limiting value of 2.0 as the stoichiometric ratio approaches zero.

This apparatus uses a flow system consisting of syringes for the two reactants, an efficient mixing chamber, a flow-through absorption cell, and a receiving syringe for the mixed solution. In operation, solutions are rapidly ejected from the reactant syringes through the mixer and absorption cell and in to the receiving syringe until it is filled. Flow is then stopped abruptly. At this moment an oscilloscope (or other rapid recorder) connected to the output of a phototube is triggered to display light absorption vs. time in the now stationary sample in the absorption cell. 

be ${ }^{68}$

A plausible scheme for the reactions that occur during the overall reaction might

\section{Scheme 1}

$$
\begin{aligned}
\mathrm{U}(\mathrm{IV})+\mathrm{Cr}(\mathrm{VI}) & =\mathrm{U}(\mathrm{VI})+\mathrm{Cr}(\mathrm{IV}) \\
\mathrm{Cr}(\mathrm{IV})+\mathrm{U}(\mathrm{IV}) & =\mathrm{Cr}(\mathrm{III})+\mathrm{U}(\mathrm{V}) \\
\mathrm{U}(\mathrm{V})+\mathrm{Cr}(\mathrm{VI}) & =\mathrm{U}(\mathrm{VI})+\mathrm{Cr}(\mathrm{V}) \\
\mathrm{Cr}(\mathrm{V})+\mathrm{U}(\mathrm{IV}) & =\mathrm{Cr}(\mathrm{III})+\mathrm{U}(\mathrm{VI}) \\
\mathrm{Cr}(\mathrm{V})+\mathrm{I}^{-} & =\mathrm{Cr}(\mathrm{III})+\mathrm{I}(\mathrm{I}) \\
\mathrm{I}^{-}+\mathrm{I}(\mathrm{I}) & =\mathrm{I}_{2}
\end{aligned}
$$

When $\mathrm{Np}(\mathrm{IV})$ or $\mathrm{Pu}(\mathrm{IV})$ is oxidized with $\mathrm{Cr}(\mathrm{VI})$, significant amounts of $\mathrm{Cr}(\mathrm{III})$ $\mathrm{Np}(\mathrm{V})$ or $\mathrm{Cr}(\mathrm{III}) \cdot \mathrm{Pu}(\mathrm{V})$ complexes are known to form. ${ }^{32}$ Therefore it is reasonable to expect the analogous $U(V)$ complex to form in the second step and to react in the third. The fourth and fifth reactions in Scheme 1 show a competition for $\mathrm{Cr}(\mathrm{V})$. When $\left[\mathrm{I}^{-}\right] \gg[\mathrm{U}(\mathrm{IV})]$, the overall reaction would be

$$
2 \mathrm{U}(\mathrm{IV})+2 \mathrm{I}^{-}+2 \mathrm{Cr}(\mathrm{VI})=2 \mathrm{U}(\mathrm{VI})+\mathrm{I}_{2}+2 \mathrm{Cr}(\mathrm{III})
$$

which gives a limiting induction factor of 0.5 . Since the observed limiting factor is 2.0 , the mechanism must be rejected.

Another possibility ${ }^{67}$ might be

\section{Scheme 2}

$$
\begin{aligned}
\mathrm{U}(\mathrm{IV})+\mathrm{Cr}(\mathrm{VI}) & =\mathrm{U}(\mathrm{VI})+\mathrm{Cr}(\mathrm{IV}) \\
\mathrm{Cr}(\mathrm{IV})+\mathrm{Cr}(\mathrm{VI}) & =2 \mathrm{Cr}(\mathrm{V}) \\
\mathrm{Cr}(\mathrm{V})+\mathrm{U}(\mathrm{IV}) & =\mathrm{Cr}(\mathrm{III})+\mathrm{U}(\mathrm{VI}) \\
\mathrm{Cr}(\mathrm{V})+\mathrm{I}^{-} & =\mathrm{Cr}(\mathrm{III})+\mathrm{I}(\mathrm{I}) \\
\mathrm{I}^{-}+\mathrm{I}(\mathrm{I}) & =\mathrm{I}_{2}
\end{aligned}
$$

For this scheme, when $\left[\mathrm{I}^{-}\right] \gg[\mathrm{U}(\mathrm{IV})]$, the stoichiometry is given by

$$
\mathrm{U}(\mathrm{IV})+4 \mathrm{I}^{-}+2 \mathrm{Cr}(\mathrm{VI})=\mathrm{U}(\mathrm{VI})+2 \mathrm{I}_{2}+2 \mathrm{Cr}(\mathrm{III})
$$

which is in agreement with the observed induction factor. This mechanism requires that $\mathrm{Cr}_{\mathrm{r}}(\mathrm{IV})$ react much faster with $\mathrm{Cr}$ (VI) than with U(IV). This is puzzling since $\mathrm{Cr}(\mathrm{IV})$ appears to react rapidly with either $\mathrm{Np}$ (IV) or $\mathrm{Pu}(\mathrm{IV})$, both of which are poorer reducing agents than U(IV). Also, there is some doubt ${ }^{69}$ that the reaction between $\mathrm{Cr}(\mathrm{IV})$ and $\mathrm{Cr}(\mathrm{VI})$ occurs rapidly at all.

Another possibility, which avoids the objections mentioned, is

\section{Scheme 3}

$$
\begin{aligned}
\mathrm{U}(\mathrm{IV})+\mathrm{Cr}(\mathrm{VI}) & =\mathrm{U}(\mathrm{V})+\mathrm{Cr}(\mathrm{V}) \\
\mathrm{U}(\mathrm{V})+\mathrm{Cr}(\mathrm{VI}) & =\mathrm{U}(\mathrm{VI})+\mathrm{Cr}(\mathrm{V})
\end{aligned}
$$




$$
\begin{aligned}
\mathrm{Cr}(\mathrm{V})+\mathrm{U}(\mathrm{IV}) & =\mathrm{Cr}(\mathrm{III})+\mathrm{U}(\mathrm{VI}) \\
\mathrm{Cr}(\mathrm{V})+\mathrm{I}^{-} & =\mathrm{Cr}(\mathrm{III})+\mathrm{I}(\mathrm{I}) \\
\mathrm{I}^{-}+\mathrm{I}(\mathrm{I}) & =\mathrm{I}_{2}
\end{aligned}
$$

This scheme has the same limiting stoichiometry as Scheme 2 and is in agreement with the observations. The intermediate $\mathrm{Cr}$ (IV) does not appear in Scheme 3, because the $\mathrm{Cr}(\mathrm{V})$ is postulated to be reduced directly to $\mathrm{Cr}(\mathrm{III})$ by $\mathrm{U}(\mathrm{IV})$ (or I). The potentials suggest that this is much less likely for $\mathrm{Np}$ (IV) or $\mathrm{Pu(IV)}$; this is consistent with the apparent formation of $\mathrm{Cr}$ (IV) and the observation of significant concentrations of the $\mathrm{Cr}(\mathrm{III}) \cdot \mathrm{An}(\mathrm{V})$ complexes when either $\mathrm{Np}$ (IV) or Pu(IV) is oxidized with $\mathrm{Cr}(\mathrm{VI})$.

Oxygen-18 transfer studies ${ }^{70}$ have shown that under some circumstances up to 1.2 of the two oxygen atoms on the $\mathrm{UO}_{2}^{2+}$ product come from the $\mathrm{HCrO}_{4}^{-}$. One explanation for this involves a doubly oxygen-bridged activated complex for one of the steps in the mechanism. This efficiency of oxygen transfer also requires that, if $\mathrm{U}(\mathrm{V})$ is formed in a series of reactions such as those in Scheme 3, it must be consumed fairly rapidly. This follows from the fact that U(VI) exchanges its oxygens rapidly with the solvent water in the presence of U(V) (Ref. 71). 


\section{REACTIONS AMONG THE IONS OF URANIUM, NEPTUNIUM, AND PLUTONIUM}

Reactions among the ions of uranium, neptunium, and plutonium are particularly interesting because they provide sets of formally similar reactions that differ only in the driving force, $\Delta \mathrm{G}$. Also, the reactions among the various oxidation states of the same element are important because they determine the stability of partially oxidized or reduced solutions of the element and often influence the course of reactions with other oxidizing or reducing agents.

The +7 states of neptunium and plutonium can be made in alkaline solution, either electrolytically or by the use of strong oxidizing agents such as ozone. ${ }^{71}$ They are extremely powerful oxidizing agents, especially in acid solutions, and are capable of rapid reaction with actinide ions in their lower oxidation states. The reaction between $\mathrm{Pu}(\mathrm{VII})$ and $\mathrm{Np}$ (VI) has been observed in $1 M \mathrm{NaOH}$ (Ref. 72), but no quantitative information is available in acid solutions. Qualitative experiments in acid solutions have shown that $\mathrm{Np}$ (VII) reacts very rapidly with $\mathrm{Pu}$ (III) but at measurable rates with Pu(IV) (Ref. 73).

Excluding the +7 state, a variety of different reaction types are possible among actinide ions in the other four oxidation states. The simplest reactions involve the transfer of an electron without the making or breaking of metal-oxygen bonds. General equations for these reactions are

$$
\mathrm{An}^{3+}+\mathrm{An}^{\prime 4^{+}}=\mathrm{An}^{4+}+\mathrm{An}^{3+} \quad(\text { type } 1)
$$




$$
\begin{aligned}
& \mathrm{AnO}_{2}^{+}+\mathrm{An}^{\prime} \mathrm{O}_{2}^{2+}=\mathrm{AnO}_{2}^{2+}+\mathrm{An}^{\prime} \mathrm{O}_{2}^{+} \\
& \mathrm{An}^{3+}+\mathrm{An}^{\prime} \mathrm{O}_{2}^{2+}=\mathrm{An}^{4+}+\mathrm{An}^{\prime} \mathrm{O}_{2}^{+}
\end{aligned}
$$

where $\mathrm{An}$ and $\mathrm{An}^{\prime}$ represent uranium, neptunium, or plutonium. The directions in which these reactions proceed and the positions of the equilibria depend on the oxidation potentials of the individual ions involved (see Table 2.1). The only examples of reaction type 1 or 2 which have been studied thoroughly are the $\mathrm{Pu}^{3+}-\mathrm{Pu}^{4+}$ (Ref. 74) and the $\mathrm{NpO}_{2}^{+}-\mathrm{NpO}_{2}^{2+}$ (Ref. 75) exchange reactions. A preliminary experiment has indicated that the $\mathrm{PuO}_{2}^{+}-\mathrm{NpO}_{2}^{2+}$ reaction is quite rapid. ${ }^{32}$

In addition to these three reaction types, there are three others in which metal-oxygen bonds are formed or broken. These are

$$
\begin{array}{cc}
\mathrm{An}^{4+}+\mathrm{An}^{\prime} \mathrm{O}_{2}^{+}=\mathrm{AnO}_{2}^{+}+\mathrm{An}^{\prime 4+} & \text { (type 4) } \\
4 \mathrm{H}^{+}+\mathrm{An}^{3+}+\mathrm{An}^{\prime} \mathrm{O}_{2}^{+}=\mathrm{An}^{4+}+\mathrm{An}^{\prime 4+}+2 \mathrm{H}_{2} \mathrm{O} & \text { (type 5) } \\
4 \mathrm{H}^{+}+\mathrm{AnO}_{2}^{+}+\mathrm{An}^{\prime} \mathrm{O}_{2}^{+}=\mathrm{An}^{4+}+\mathrm{An}^{\prime} \mathrm{O}_{2}^{2+}+2 \mathrm{H}_{2} \mathrm{O} & \text { (type 6) }
\end{array}
$$

We will discuss the known examples of reaction types 3 to 6 after we consider the reactions for which both An and An' are plutonium.

The reactions among the plutonium ions are particulary noteworthy because the rates and equilibria are such that under many circumstances reactions of three different types are important simultaneously. To illustrate this, we will consider first the reaction between $\mathrm{Pu}^{3+}$ and $\mathrm{PuO}_{2}^{+}$in $1 \mathrm{MHClO}_{4}$. The individual reactions that must be considered are of types 3,5 , and 6 . Written in terms of the oxidation states and without regard to hydrogen ions, they are

$$
\begin{aligned}
\mathrm{Pu}(\mathrm{III})+\mathrm{Pu}(\mathrm{V}) & \rightleftharpoons 2 \mathrm{Pu}(\mathrm{IV}) \\
\mathrm{Pu}(\mathrm{III})+\mathrm{Pu}(\mathrm{VI}) & \rightleftharpoons \mathrm{Pu}(\mathrm{IV})+\mathrm{Pu}(\mathrm{V}) \\
2 \mathrm{Pu}(\mathrm{V}) & \rightleftharpoons \mathrm{Pu}(\mathrm{IV})+\mathrm{Pu}(\mathrm{VI})
\end{aligned}
$$

Reaction 4.2 is the most rapid of the three, and under most circumstances the system will be near equilibrium with respect to it at all times. Reaction 4.1 is significantly slower and is effectively rate determining. Reaction 4.3 is enough slower than 4.1 so that it is relatively unimportant. The system is governed by two simultaneous differential equations. To simplify the notation, we will use a Roman numeral for plutonium in the indicated oxidation state. A convenient pair of differential equations is

$$
-\frac{\mathrm{d}(\mathrm{III})}{\mathrm{dt}}=\mathrm{k}_{1}(\mathrm{III})(\mathrm{V})-\mathrm{k}_{-1}(\mathrm{IV})^{2}+\mathrm{k}_{2}(\mathrm{III})(\mathrm{VI})-\mathrm{k}_{-2}(\mathrm{IV})(\mathrm{V})
$$




$$
\begin{aligned}
-\frac{d(V)}{d t}=k_{1}(I I)(V)-k_{-1}(I V)^{2}-k_{2}(I I)(V I) & +k_{-2}(I V)(V) \\
& +2 k_{3}(V)^{2}-2 k_{-3}(I V)(V I)
\end{aligned}
$$

Rate constants applicable to $1 \mathrm{M} \mathrm{HClO}_{4}$ and $25^{\circ} \mathrm{C}$ were taken from Tables 4.1, 4.2, and 4.3 , and the equations were solved numerically to give the concentrations of all the plutonium species as a function of time. Since the actual rates depend on the plutonium concentration, to make the results more general, we show in Fig. 4.1 a graph of relative concentration vs. $\tau$, which is the time in seconds multiplied by the total plutonium concentration.

Although reaction 4.1 is essentially rate determining, the overall stoichiometry changes during the course of the reaction, depending on the extent and direction of reaction 4.2 as it rapidly approaches equilibrium. At the start there is a net production of $\mathrm{Pu}(\mathrm{III})$, and the stoichiometry is given by

$$
3 \mathrm{Pu}(\mathrm{V})=\mathrm{Pu}(\mathrm{III})+2 \mathrm{Pu}(\mathrm{VI})
$$

As $\mathrm{Pu}(\mathrm{III})$ builds up, this stoichiometry changes, and, when its concentration reaches a maximum, the stoichiometry is given by Eq. 4.3. Soon after this the concentration of $\mathrm{Pu}(\mathrm{VI})$ reaches its maximum, and the stoichiometry is that of Eq. 4.1. Finally, near the end of the reaction when the $\mathrm{Pu}(\mathrm{V})$ is essentially gone, the stoichiometry is approximated by

$$
2 \mathrm{Pu}(\mathrm{III})+\mathrm{Pu}(\mathrm{VI})=3 \mathrm{Pu}(\mathrm{IV})
$$

An even more complicated example is illustrated in Fig. 4.2, which shows the behavior of a solution that is initially pure $\mathrm{Pu}(\mathrm{V})$. Again the calculation applies to $1 M$ $\mathrm{HClO}_{4}$ at $25^{\circ} \mathrm{C}$. Initially, when $[\mathrm{Pu}(\mathrm{III})]=0$, reaction 4.3 is the only rate-determining step. It is followed by the rapid reverse of reaction 4.2 so that $\mathrm{Pu}(\mathrm{III})$ is formed by the overall net reaction Eq. 4.6. As $\mathrm{Pu}$ (III) builds up, reaction 4.1 rapidly becomes important, and, when $\tau$ is about $18.8 \mathrm{M} \mathrm{sec}$, reactions 4.1 and 4.3 have equal rates. At this point the system is far from equilibrium, even with respect to reaction 4.2 ; its forward rate is only about $87 \%$ of the reverse rate. By $50 \mathrm{M} \mathrm{sec}$, however, the forward and reverse rates agree within $1.7 \%$, and from there on reaction 4.2 is essentially at equilibrium. As in the previous example, the stoichiometry changes during the course of the reaction and has integral values only when $\mathrm{d}(\mathrm{III}) / \mathrm{dt}$ or $\mathrm{d}(\mathrm{VI}) / \mathrm{dt}$ equals zero.

Only one example of a type 4 reaction has been reported. The oxidation of $\mathrm{U}^{4+}$ by $\mathrm{NpO}_{2}^{+}$was found ${ }^{88}$ to have the rate law $-\mathrm{d}[\mathrm{U}(\mathrm{IV})] / \mathrm{dt}=\mathrm{k}_{8}[\mathrm{U}(\mathrm{IV})][\mathrm{Np}(\mathrm{V})]+$ $\mathrm{k}_{9}[\mathrm{U}(\mathrm{IV})][\mathrm{Np}(\mathrm{IV})]$. This is consistent with a type 4 reaction,

$$
U(I V)+N p(V)=U(V)+N p(I V)
$$


and a type 5 reaction,

$$
\mathrm{U}(\mathrm{IV})+\mathrm{Np}(\mathrm{IV})=\mathrm{U}(\mathrm{V})+\mathrm{Np}(\mathrm{III})
$$

followed by the rapid oxidation of both $N p(I I I)$ and $U(V)$ by $N p(V)$. Reaction 4.8 is quite slow, with an activation energy of $134 \pm 8 \mathrm{~kJ} / \mathrm{mol}$ and an apparent second-order rate constant of $8.3 \times 10^{-4} \mathrm{M}^{-1} \mathrm{sec}^{-1}$ in $0.1 M \mathrm{HClO}_{4}$ at $25^{\circ} \mathrm{C}$. The $\mathrm{Np}(\mathrm{IV})-\mathrm{Np}(\mathrm{V})$ exchange reaction might be expected to be type 4 , but the observed rate law ${ }^{89}$ shows that this is not the case.

Data for the five reactions of type 3 which have been studied are listed in Table 4.1. The most important term in the individual rate laws is $\mathrm{k}^{\prime}\left[\mathrm{An}^{3+}\right]\left[\mathrm{An}^{\prime} \mathrm{O}_{2}^{2+}\right]\left[\mathrm{H}^{+}\right]^{0}$. A lack of hydrogen-ion dependence is not surprising since the overall reactions do not involve hydrogen ions. However, the Pu(III)-Np(VI) and the $\mathrm{Np}(\mathrm{III})-\mathrm{U}(\mathrm{VI})$ reactions show additional small terms inverse in $\left[\mathrm{H}^{+}\right]$. This suggests the participation of hydrolyzed species, but why it is observed for these two reactions alone is not clear.

The free energies for the reactions range widely from -95 to $+9 \mathrm{~kJ} / \mathrm{mol}$, and, in general, the rates decrease as the driving force for reaction decreases. This is shown in Fig. 4.3 , where $\Delta \mathrm{G}^{*}$ is plotted vs. $\Delta \mathrm{G}$. The rates for the two reactions involving $U_{2}^{2+}$ are unexpectedly large in that the points for these reactions fall below the line through the points for the other reactions.

The heats of activation for the five reactions are all quite low, ranging from 4.2 to $20 \mathrm{~kJ} / \mathrm{mol}$. The entropies of activation are negative as would be expected for reactions between ions of like sign. Except for the U(III)-U(VI) reaction, $\Delta S^{*}$ trends toward more positive values as $\Delta \mathrm{G}$ increases.

Six of the nine possible reactions of type 5 have been studied, and the results are summarized in Table 4.2. The oxidation potentials are such that two of the plutonium reactions proceed in the direction opposite to the others. The rate constants and other activation parameters for these reactions have been recalculated for the reverse direction for comparison. On this basis all the reactions show a common term in their rate laws: $\mathrm{k}\left[\mathrm{An}^{3+}\right]\left[\mathrm{An}^{\prime} \mathrm{O}_{2}^{+}\right]\left[\mathrm{H}^{+}\right]^{n}$, where $\mathrm{n}=1$--except for the $\mathrm{Pu}^{3+}-\mathrm{UO}_{2}^{+}$reaction, where $n=2$. The observed $\left[\mathrm{H}^{+}\right]$dependence suggests that the species $\mathrm{HOAn}^{\prime} \mathrm{O}^{2+}$ is a reactive intermediate. It must be a strong acid, however, because no other evidence for its existence has been found.

The overall reduction of $\mathrm{AnO}_{2}^{+}$to $\mathrm{An}^{4+}$ requires four hydrogen ions to convert the two oxide ligands to water. Since the activated complex has a configuration that lies along the reaction path, it is reasonable that one or more of these hydrogen ions is required for the formation of the activated complex, as is observed. Interestingly, the reaction with the smallest driving force is the one for which $n=2$. Also, the $\mathrm{U}^{3+}-\mathrm{UO}_{2}^{+}$reaction, which has the largest driving force of the series, has a small term in the rate law for which $n=0$. These results are consistent with the idea that, in a series of similar reactions, the activated complexes will more nearly resemble the reactants if the driving force is large but will tend to resemble the products if the driving force is small. 
Table 4.1

TYPE 3 REACTIONS AMONG THE IONS OF URANIUM, NEPTUNIUM, AND PLUTONIUM†

\begin{tabular}{|c|c|c|c|c|c|c|c|c|}
\hline Reaction & $\begin{array}{c}\Delta G, \\
\mathrm{~kJ} / \mathrm{mol} \\
(\mathrm{kcal} / \mathrm{mol})\end{array}$ & $\begin{array}{c}\Delta \mathbf{H}, \\
\mathrm{kJ} / \mathrm{mol} \\
(\mathrm{kcal} / \mathrm{mol})\end{array}$ & $\begin{array}{c}\Delta S, \\
3 / \mathrm{mol} \cdot \mathrm{K} \\
(\mathrm{cal} / \mathrm{mol} \cdot \mathrm{deg})\end{array}$ & $\begin{array}{c}\mathrm{k}^{\prime \prime} \\
M^{-1} \sec ^{-1}\end{array}$ & $\begin{array}{c}\Delta \mathrm{G}^{*}, \\
\mathrm{~kJ} / \mathrm{mol} \\
(\mathrm{kcal} / \mathrm{mol})\end{array}$ & $\begin{array}{c}\Delta \mathrm{H}^{*}, \\
\mathrm{~kJ} / \mathrm{mol} \\
(\mathrm{kcal} / \mathrm{mol})\end{array}$ & $\begin{array}{c}\Delta \mathbf{S}^{*}, \\
\mathbf{J} / \mathbf{m o l} \cdot \mathbf{K} \\
(\mathrm{cal} / \mathrm{mol} \cdot \mathrm{deg})\end{array}$ & Ref. \\
\hline $\begin{array}{c}\mathrm{Np}^{3+}+\mathrm{NpO}_{2}^{2+}= \\
\mathrm{Np}^{4+}+\mathrm{NpO}_{2}^{+}\end{array}$ & $\begin{array}{l}-94.8 \\
(22.65)\end{array}$ & $\begin{array}{l}-141.0 \\
(33.8)\end{array}$ & $\begin{array}{l}-157 \\
(-37.6)\end{array}$ & $1.05 \times 10^{5}$ & $\begin{array}{l}44.4 \\
(10.6)\end{array}$ & $\begin{array}{l}4.2 \\
(1.0)\end{array}$ & $\begin{array}{l}-134 \\
(-32)\end{array}$ & 76 \\
\hline $\mathrm{U}^{3+}+\mathrm{UO}_{2}^{2+}=$ & -66.9 & -112.5 & -148 & $5.5 \times 10^{4}$ & 46.0 & 18.1 & $\begin{array}{l}(-32) \\
-93\end{array}$ & 10 \\
\hline $\mathrm{U}^{4+}+\mathrm{UO}_{2}^{+}$ & $(-16.0)$ & $(-26.9)$ & $(-35.5)$ & & (11.0) & $(4.3 \pm 0.2)$ & $(-22.3 \pm 0.6)$ & 76 \\
\hline $\mathrm{Pu}^{3+}+\mathrm{NpO}_{2}^{2+}=$ & -15.1 & -60.7 & -153 & $35.5+$ & 64.2 & 14.6 & -166 & \\
\hline $\mathrm{Pu}^{4+}+\mathrm{NpO}_{2}^{+}$ & $(-3.6)$ & $(-14.5)$ & $(-36.6)$ & $3.1\left[\mathrm{H}^{+}\right]^{-\mathrm{t}}$ & (15.34) & (3.49) & $(-39.7 \pm 0.2)$ & 77 \\
\hline $\mathrm{Pu}^{3+}+\mathrm{PuO}_{2}^{2+2}=$ & 6.3 & -35.6 & -140 & 2.7 & 70.5 & 20.2 & -169 & \\
\hline $\mathrm{Pu}^{4+}+\mathrm{PuO}_{2}^{+}$ & (1.51) & $(-8.5)$ & $(-33.4)$ & & $(16.86)$ & $(4.83 \pm 0.1)$ & $(-40.4 \pm 0.3)$ & 78 \\
\hline $\begin{array}{c}\mathrm{Np}^{3+}+\mathrm{UO}_{2}^{2+2}= \\
\mathrm{Np}^{4+}+\mathrm{UO}_{2}^{+}\end{array}$ & $\begin{array}{l}8.9 \\
(2.13)\end{array}$ & $\begin{array}{l}-35.9 \\
(-8.6)\end{array}$ & $\begin{array}{l}-151 \\
(-36)\end{array}$ & $\begin{array}{l}38.8+ \\
\quad 1.4\left[\mathrm{H}^{+}\right]^{-1}\end{array}$ & $\begin{array}{l}64.0 \\
(15.29)\end{array}$ & $\begin{array}{l}10.9 \\
(2.6 \pm 0.16)\end{array}$ & $\begin{array}{l}-178 \\
(-42.6 \pm 0.6)\end{array}$ & 12 \\
\hline
\end{tabular}

$\dagger$ Values are for $25^{\circ} \mathrm{C}$ and $\mu=1 \mathrm{M}$. 
Table 4.2

TYPE 5 REACTIONS AMONG THE IONS OF URANIUM, NEPTUNIUM, AND PLUTONIUM +

\begin{tabular}{|c|c|c|c|c|c|c|c|c|c|}
\hline Reaction & $\begin{array}{c}\Delta \mathrm{G} \\
\mathrm{kJ} / \mathrm{mol} \\
(\mathrm{kcal} / \mathrm{mol})\end{array}$ & $\begin{array}{c}\Delta \mathbf{H J} / \mathbf{m o l} \\
(\mathrm{kcal} / \mathrm{mol})\end{array}$ & $\begin{array}{c}\Delta S, \\
\mathrm{~J} / \mathrm{mol} \cdot \mathrm{K} \\
(\mathrm{cal} / \mathrm{mol} \cdot \mathrm{deg})\end{array}$ & $M^{-1} \mathrm{sec}^{\prime \prime}$ & $\stackrel{\mu}{M}$ & $\begin{array}{c}\Delta \mathrm{G}^{*} \\
\mathrm{~kJ} / \mathrm{mol} \\
(\mathrm{kcal} / \mathrm{mol})\end{array}$ & $\begin{array}{c}\Delta \mathrm{H}^{*} \\
\mathrm{~kJ} / \mathrm{mol} \\
(\mathrm{kcal} / \mathrm{mol})\end{array}$ & $\begin{array}{c}\Delta S^{*} \\
J / \mathrm{mol} \cdot \mathbf{K} \\
(\mathrm{cal} / \mathrm{mol} \cdot \mathrm{deg})\end{array}$ & Ref. \\
\hline $\begin{array}{c}\mathrm{U}^{3+}+\mathrm{UO}_{2}^{+}+4 \mathrm{H}^{+}= \\
2 \mathrm{U}^{4+}+2 \mathrm{H}_{2} \mathrm{O}\end{array}$ & $\begin{array}{l}-119.2 \\
(-28.5)\end{array}$ & $\begin{array}{l}-225 \\
(-53.7)\end{array}$ & $\begin{array}{l}-354 \\
(-84.5)\end{array}$ & $\begin{array}{l}\left(0.9+4.7\left[\mathrm{H}^{+}\right]\right) 10^{5} \\
\left(0.55 \pm 1.3\left[\mathrm{H}^{+}\right]\right) 10^{5}\end{array}$ & $\begin{array}{l}1.0 \\
0.2\end{array}$ & $\begin{array}{l}40.6 \\
(9.7) \\
43.9 \\
(10.5)\end{array}$ & $\begin{array}{l}8.4 \pm 1.7 \\
(2 \pm 0.4) \\
7.5 \pm 1.7 \\
(1.8 \pm 0.4)\end{array}$ & $\begin{array}{l}-109 \pm 5 \\
(-26 \pm 1.3) \\
-121 \pm 5 \\
(-29 \pm 1.3)\end{array}$ & $\begin{array}{l}76 \\
76\end{array}$ \\
\hline $\begin{array}{c}\mathrm{Np}^{3+}+\mathrm{NpO}_{2}^{+}+4 \mathrm{H}^{+}= \\
2 \mathrm{~Np}^{4+}+2 \mathrm{H}_{2} \mathrm{O}\end{array}$ & $\begin{array}{l}-56.3 \\
(-13.46)\end{array}$ & $\begin{array}{l}-173 \\
(-41.3)\end{array}$ & $\begin{array}{l}-391 \\
(-93.5)\end{array}$ & $\begin{array}{l}43\left[\mathrm{H}^{+}\right] \\
15\left[\mathrm{H}^{+}\right]\end{array}$ & $\begin{array}{l}2.0 \\
1.0\end{array}$ & $\begin{array}{l}63.7 \\
(15.22) \\
66.1 \\
(15.8)\end{array}$ & $\begin{array}{l}24.7 \pm 2 \\
(5.9 \pm 0.5) \\
24.7 \pm 2 \\
(5.9 \pm 0.5)\end{array}$ & $\begin{array}{l}-128 \pm 8 \\
(-31 \pm 2) \\
-138 \pm 10 \\
(-33 \pm 2)\end{array}$ & $\begin{array}{l}79 \\
\text { Estimate }\end{array}$ \\
\hline $\begin{array}{c}\mathrm{Np}^{3+}+\mathrm{UO}_{2}^{4}+4 \mathrm{H}^{+}= \\
\mathrm{Np}^{4+}+\mathrm{U}^{4+}+2 \mathrm{H}_{2} \mathrm{O} \\
\mathrm{Pu}^{3+}+\mathrm{PuO}_{2}^{+}+4 \mathrm{H}^{+}=\end{array}$ & $\begin{array}{l}-43.4 \\
(-10.37) \\
-18.2\end{array}$ & $\begin{array}{l}-149 \\
(-35.7) \\
-121\end{array}$ & $\begin{array}{l}-356 \\
(-85.2) \\
-344\end{array}$ & $\begin{array}{l}38\left[\mathrm{H}^{+}\right] \\
4.4 \times 10^{-2}\left[\mathrm{H}^{+}\right]\end{array}$ & 1.0 & $\begin{array}{l}64.0 \\
(15.29) \\
80.8\end{array}$ & $\begin{array}{l}21.3 \pm 1.7 \\
(5.1 \pm 0.4) \\
33.5 \pm 0.5\end{array}$ & $\begin{array}{l}-143 \pm 5 \\
(-34.1 \pm 1.2) \\
-158 \pm 2\end{array}$ & 12 \\
\hline $\begin{array}{l}2 \mathrm{Pu}^{4+}+2 \mathrm{H}_{2} \mathrm{O} \\
\mathrm{Np}^{4+}+\mathrm{Pu}^{4+}+2 \mathrm{H}_{2} \mathrm{O}= \\
\mathrm{NpO}_{2}^{+}+\mathrm{Pu}^{3+}+4 \mathrm{H}^{+}\end{array}$ & $\begin{array}{l}(-4.34) \\
-23.4 \\
(-5.60)\end{array}$ & $\begin{array}{l}(-28.9) \\
92 \\
(22.0)\end{array}$ & $\begin{array}{l}(-82.2) \\
387 \\
(92.5)\end{array}$ & $\begin{array}{l}0.253\left[\mathrm{H}^{+}\right]^{-3} \\
2.2 \times 10^{-5}\left[\mathrm{H}^{+}\right]\end{array}$ & $\begin{array}{l}2.0 \\
1.0\end{array}$ & $\begin{array}{l}(19.3) \\
76.6 \\
(18.3) \\
99.6 \\
(23.8)\end{array}$ & $\begin{array}{l}(8.0 \pm 0.1) \\
142 \pm 6 \\
(33.9 \pm 1.5) \\
50 \\
(11.9)\end{array}$ & $\begin{array}{l}(-37.8 \pm 0.4) \\
218 \pm 21 \\
(52 \pm 5) \\
-167 \pm 21 \\
(-40 \pm 5)\end{array}$ & $\begin{array}{l}81 \\
\$\end{array}$ \\
\hline $\begin{array}{c}\mathrm{U}^{4+}+\mathrm{Pu}^{4+}+2 \mathrm{H}_{2} \mathrm{O}= \\
\mathrm{UO}_{2}^{+}+\mathrm{Pu}^{3+}+4 \mathrm{H}^{+}\end{array}$ & $\begin{array}{l}-36.4 \\
(-8.69)\end{array}$ & $\begin{array}{l}68.5 \\
(16.4)\end{array}$ & $\begin{array}{l}352 \\
(84.2)\end{array}$ & $\begin{array}{l}34.4\left[\mathrm{H}^{+}\right]^{-2} \\
1.9 \times 10^{-5}\left[\mathrm{H}^{+}\right]^{2}\end{array}$ & $\begin{array}{l}2.0 \\
1.0\end{array}$ & $\begin{array}{l}64.3 \\
(15.36) \\
100 \\
(23.9)\end{array}$ & $\begin{array}{l}102 \pm 2.5 \\
(24.3 \pm 0.6) \\
33.1 \\
(7.9)\end{array}$ & $\begin{array}{l}126 \pm 8 \\
(30 \pm 2) \\
-216 \pm 8 \\
(52 \pm 2)\end{array}$ & $\begin{array}{l}82 \\
\vdots\end{array}$ \\
\hline
\end{tabular}

+ Values are for $25^{\circ} \mathrm{C}$

$¥$ An estimate for the reverse action. 
Table 4.3

TYPE 6 REACTIONS AMONG THE IONS OF URANIUM, NEPTUNIUM, AND PLUTONIUM ${ }^{a}$

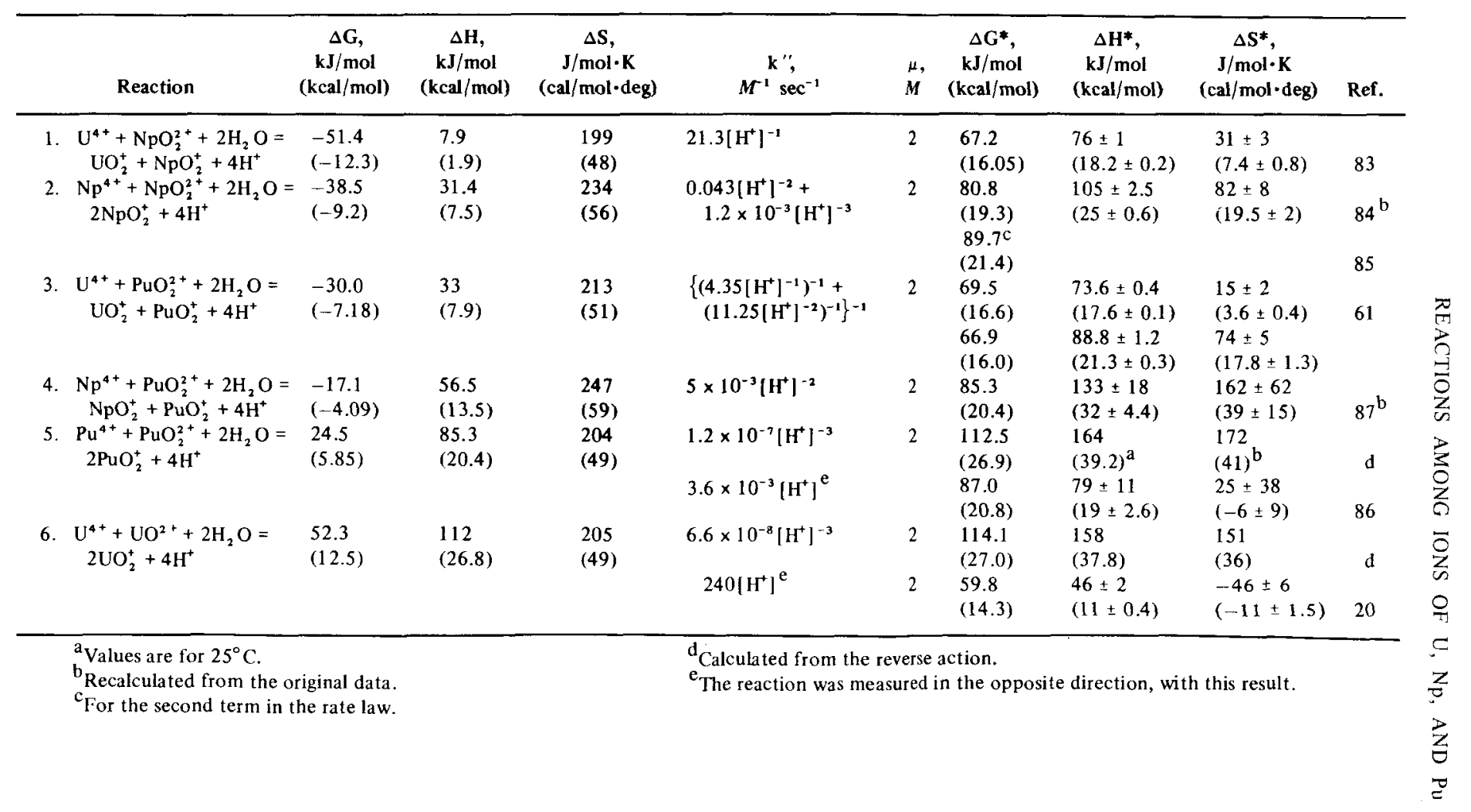




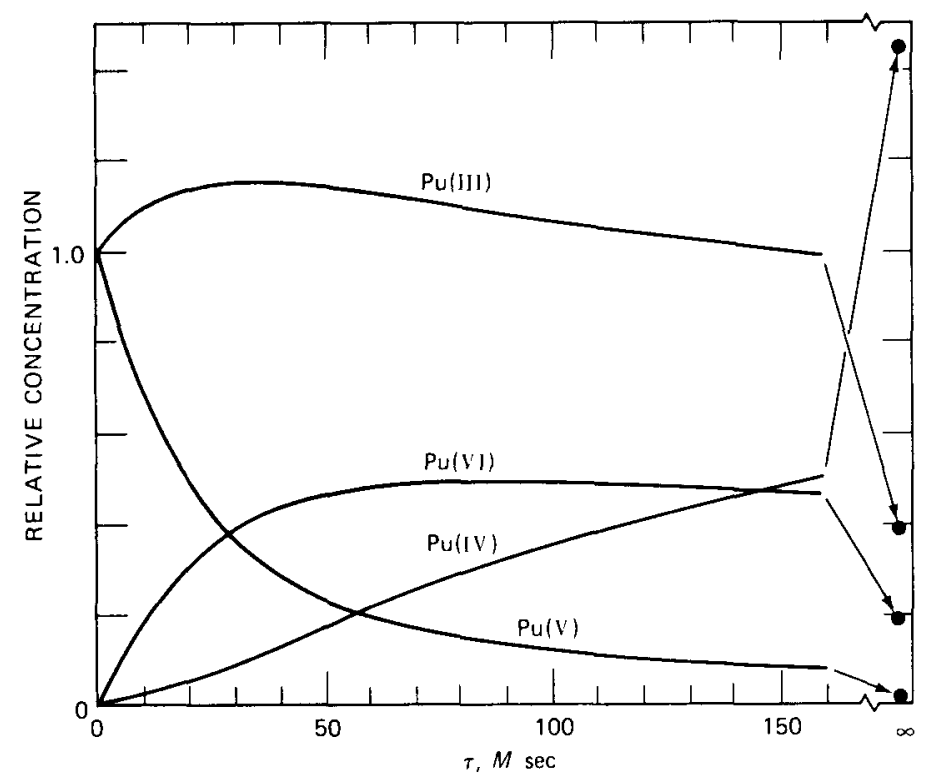

Fig. 4.1 The course of the $\mathrm{Pu}(\mathrm{III})-\mathrm{Pu}(\mathrm{V})$ reaction in $1 \mathrm{MHClO}_{4}$ at $25^{\circ} \mathrm{C}$.

This same argument can be used to rationalize the observation that the $\Delta S^{*}$ values become more positive as the $\Delta \mathrm{G}^{*}$ values decrease. The overall reactions show large decreases in entropy as highly charged +4 ions are formed from ions of lesser charges. Lower values of $\Delta \mathrm{G}^{*}$ (and $\Delta \mathrm{G}$ ) imply smaller reorganization of the reactant ions toward the product ions and hence less negative $\Delta S^{*}$ values than for the reactions with larger $\Delta \mathrm{G}^{*}$ values.

The reaction rates vary widely, by a factor of about $10^{10}$, but depend primarily on the driving force. This is shown in Fig. 4.4, where $\Delta \mathrm{G}^{*}$ is plotted vs. $\Delta \mathrm{G}$. The value for the $\mathrm{Pu}^{3+}-\mathrm{UO}_{2}^{+}$reaction, shown as a $\Delta$ in the figure, lies below the function through the other points. This is as expected because the hydrogen-ion dependence is different. For this reaction $\Delta G^{*}$ for the undetected term in the rate law which is first power in $\left[\mathrm{H}^{+}\right]$should be at least $8 \mathrm{~kJ} / \mathrm{mol}$ greater than the value for the observed term.

Although it is not known whether the mechanism of these reactions should be classed as inner sphere or outer sphere, it is interesting to apply Marcus's cross relation (Eq. 2.8) to the data since most of the assumptions on which it is based might be expected to apply to either case. The work required to bring the ions to reaction distance, the work terms in Eq. 2.8, are usually quite small, but for these reactions they must include the work of forming the presumed intermediates, $\mathrm{HOAnO}^{2+}$ and $\mathrm{HOAnO}^{+}$. A reasonable estimate for the total of these terms lies between 20 and $40 \mathrm{~kJ} / \mathrm{mol}$. If Eq. 2.8 is used as a semi-empirical function to describe the data, the best values for the parameters are $\Delta \mathrm{G}_{1}^{*}{ }_{1}+\Delta \mathrm{G}_{2}^{*}{ }_{2}=176 \pm 4 \mathrm{~kJ} / \mathrm{mol}$ and 


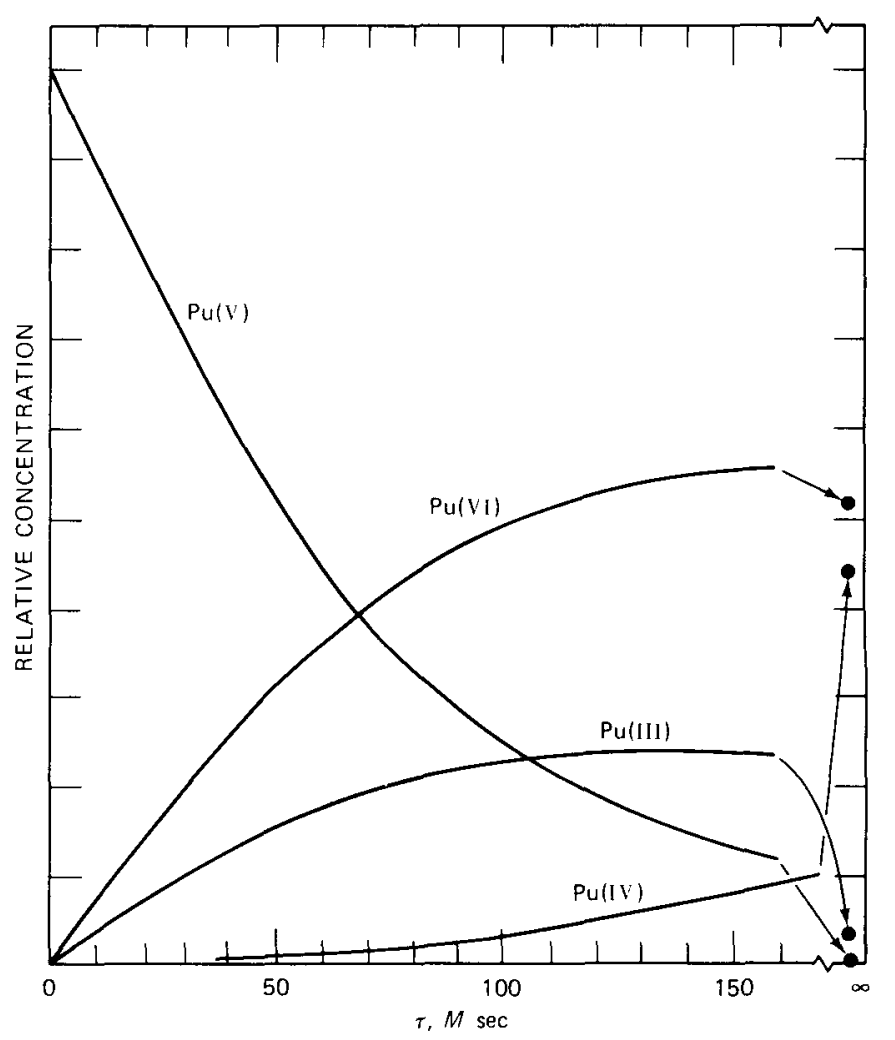

Fig. 4.2 The course of the disproportionation of $\mathrm{Pu}(\mathrm{V})$ in $1 M \mathrm{HClO}_{4}$ at $25^{\circ} \mathrm{C}$.

$w_{11}+w_{22}=12 \pm 40 \mathrm{~kJ} / \mathrm{mol}$. The line in Fig. 4.4 was drawn using these parameters. Since the large uncertainty in the work-term parameter includes all reaonable estimates for its value, the Marcus expression is physically reasonable. It should be emphasized, however, that this agreement is not proof that these type 5 reactions proceed by an outer-sphere mechanism.

The results for type 6 reactions are summarized in Table 4.3. The last two reactions, with positive $\Delta \mathrm{G}$ values, were measured in the opposite direction but have been recalculated for comparison with the others. The rate laws for all the reactions were found to be first power in each actinide ion, but different hydrogen-ion dependences were observed. Since terms in the rate laws showed hydrogen-ion dependences ranging from -1 to -3 , the net activation processes can be written

$$
\mathrm{An}^{4+}+\mathrm{An}^{\prime} \mathrm{O}_{2}^{2+}+2 \mathrm{H}_{2} \mathrm{O}=\left[{ }^{*}\right]^{6-\mathrm{n}}+\mathrm{nH}^{+}
$$

with $\mathrm{n}=1,2$, and 3 . In addition, the $\mathrm{U}^{4+}-\mathrm{PuO}_{2}^{2+}$ reaction occurs by consecutive rate-determining steps (the 2-1 pattern described in Fig. 2.1 and Sec. 2-3). The observed hydrogen-ion dependences, or the number of hydrogen ions released when 


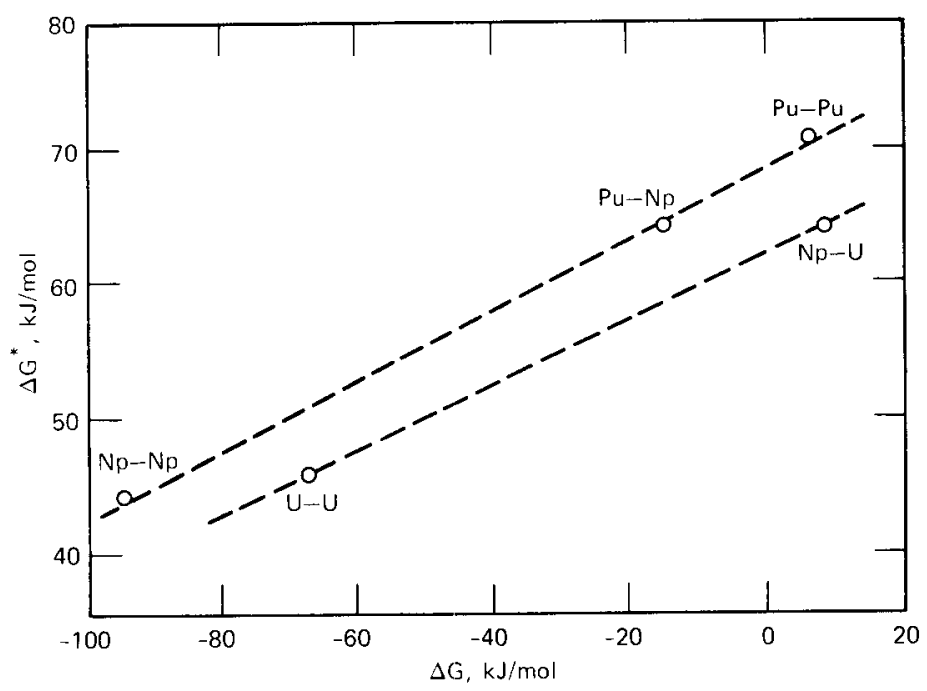

Fig. 4.3 $\Delta \mathrm{G}^{*}$ vs. $\Delta \mathrm{G}$ for type 3 reactions: $\mathrm{An}^{3+}+\mathrm{AnO}_{2}^{2+}=\mathrm{An}^{4+}+\mathrm{AnO}_{2}^{+}$.

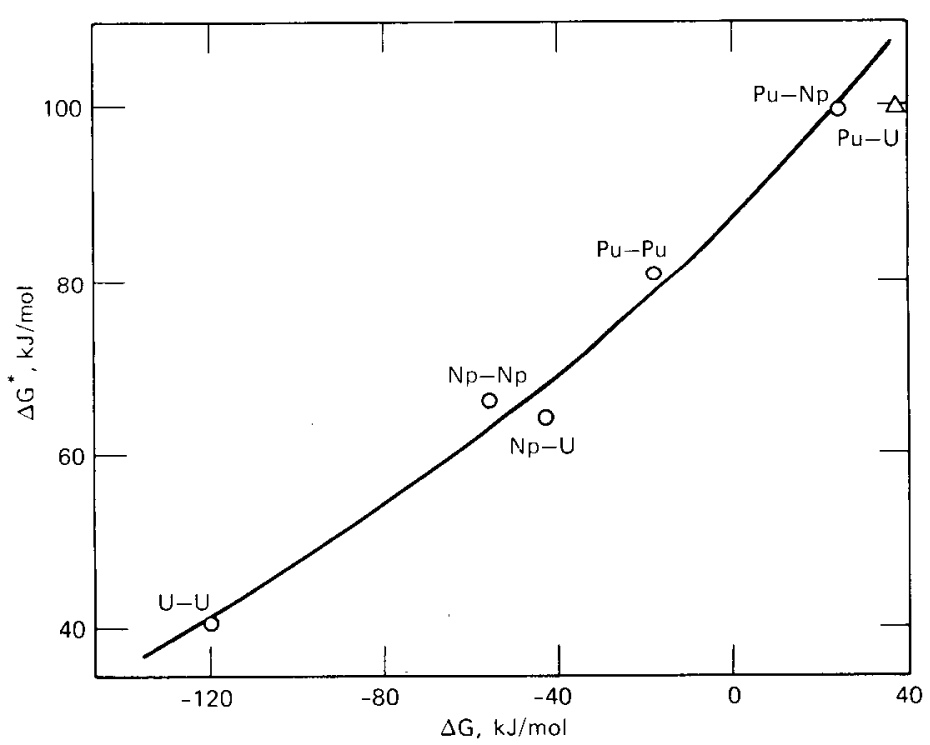

Fig. 4.4 $\Delta \mathrm{G}^{*}$ vs. $\Delta \mathrm{G}$ for type 5 reactions: $\mathrm{An}^{3+}+\mathrm{AnO}_{2}^{+}+4 \mathrm{H}^{+}=\mathrm{An}^{4+}+\mathrm{An}^{4+}+2 \mathrm{H}_{2} \mathrm{O}$. 
the activated complex is formed, shows a rough dependence on $\Delta \mathrm{G}$. The reaction with the largest driving force shows an inverse first-power dependence, but the two reactions with the smallest driving forces are inverse third power in $\left[\mathrm{H}^{+}\right]$.

Figure 4.5 shows a graph of $\Delta \mathrm{G}^{*}$ vs. $\Delta \mathrm{G}$ for six type 6 reactions that have been studied carefully. In addition, a preliminary value ${ }^{77}$ for the $\mathrm{Pu}^{4+}-\mathrm{NpO}_{2}^{2+}$ is shown.

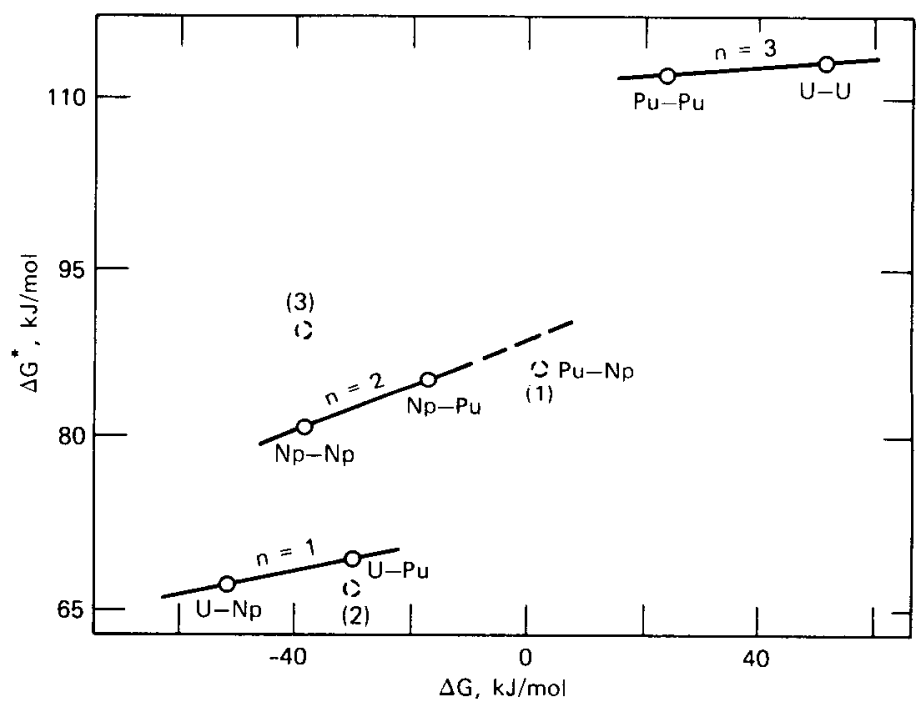

Fig. 4.5 $\Delta \mathrm{G}^{*}$ vs. $\Delta \mathrm{G}$ for type 6 reactions: $\mathrm{An}^{4+}+\mathrm{AnO}_{2}^{2+}+2 \mathrm{H}_{2} \mathrm{O}=\mathrm{AnO}_{2}^{+}+\mathrm{AnO}_{2}^{+}+4 \mathrm{H}^{+}$, where $\mathrm{n}$ on the figure is the number of $\mathrm{H}^{+}$released in the net activation process.

Three separate lines were drawn to distinguish among the reactions with different hydrogen-ion dependences. Because they are based on rate constants with different dimensions, the $\Delta \mathrm{G}^{*}$ values for the different dependences are not comparable. For $\mathrm{n}=1,2$, and 3, the dimensions are $\sec ^{-1}, M \sec ^{-1}$, and $M^{2} \sec ^{-1}$, respectively. Thus, except for $n=1$, the numerical values of $\Delta \mathrm{G}^{*}$ depend on the concentration units employed, and meaningful intercomparisons are difficult.

Within groups with the same values for $n$, the effect of $\Delta G$ on $\Delta G^{*}$ is smaller than that shown by the type 3 and type 5 reactions. A possible explanation is that the rate-determining step in the type 6 reactions is the formation of an inner-sphere complex (step 3 in the general mechanism given in Sec. 2-2) rather than the electron transfer itself. The conclusion that the U(IV) - Pu(VI) reaction involves two consecutive rate-determining steps is consistent with this idea if the first step involves substitution and electron transfer occurs in the second step. This would also explain the fact that the point for $n=2$ for this reaction is not in agreement with the other points with $n=2$. In this connection we should note that consecutive rate-determining steps were shown to be consistent with the hydrogen-ion dependence observed for the disproportionation of $\mathrm{UO}_{2}^{+}$, the reverse of the $\mathrm{U}^{4+}-\mathrm{UO}_{2}^{2+}$ reaction. 


\section{EFFECTS OF SELF-IRRADIATION J IN PLUTONIUM SOLUTIONS}

The most common isotope of plutonium, ${ }^{239} \mathrm{Pu}$, emits alpha particles with an average energy of about $5.15 \mathrm{MeV}$ and a half-life of 24,360 years. For plutonium in solution this amounts to the deposition of energy at a rate of $0.401 \mathrm{eV}$ per day per atom of plutonium. Alpha radiation ionizes water in dense tracks, probably producing $\mathrm{H}_{2} \mathrm{O}^{+}$ and $\mathrm{e}$ initially; in acid solutions these are equivalent to the radicals $\mathrm{H}$ and $\mathrm{OH}$. In the tracks these radicals can recombine, react to give the molecules $\mathrm{H}_{2}$ and $\mathrm{H}_{2} \mathrm{O}_{2}$, or diffuse out into the bulk of the solution. Interaction between the radiation and various solutes will be relatively unimportant because their concentrations will usually be much less than the concentration of water. The reaction between $\mathrm{H}_{2} \mathrm{O}_{2}$ and $\mathrm{OH}$ in the alpha-particle tracks probably produces an additional species, the radical $\mathrm{HO}_{2}$. In addition, various solutes can probably react with radicals in the tracks.

The yields of the various species that diffuse out of the radiation tracks are expressed by the symbol $\mathrm{G}$ in units of molecules (or radicals) per $100 \mathrm{eV}$ absorbed. For alpha radiation of about $5 \mathrm{MeV}$, the yields of the most important species are: $\mathrm{G}_{\mathrm{H}_{2}} \approx 1.6, \mathrm{G}_{\mathrm{H}_{2} \mathrm{O}_{2}} \approx 1.35, \mathrm{G}_{\mathrm{H}} \approx 0.6, \mathrm{G}_{\mathrm{OH}} \approx 0.4$, and $\mathrm{G}_{\mathrm{HO}_{2}} \approx 0.22$ (Ref. 90).

The observed radiolytic effects depend on the reactions of the plutonium ions and other solutes with the radicals $\mathrm{H}, \mathrm{OH}$, and $\mathrm{HO}_{2}$, as well as with $\mathrm{H}_{2} \mathrm{O}_{2}$. Since all these radiolytic species are capable of reacting as either oxidizing or reducing agents depending on conditions, it is not surprising that the resulting chemistry is quite complicated. 
In $\mathrm{HClO}_{4}$ solutions both $\mathrm{Pu}(\mathrm{VI})$ and $\mathrm{Pu}(\mathrm{IV})$ are reduced at rates such that the mean oxidation number, $\overline{\text { ox }}, \dagger$ decreases by 0.013 (Refs. 91, 92) to 0.015 (Ref.93) per day. These values correspond to radiolytic yields from $G=3.2$ to $G=3.7$ atom equivalents (at. eq.) per $100 \mathrm{eV}$. The lower of these values is in good agreement with the value for the reduction of $\mathrm{Ce}(\mathrm{IV})$ in $0.8 \mathrm{~N} \mathrm{H}_{2} \mathrm{SO}_{4}$, where $\mathrm{G}=3.2$ for irradiation by alpha particles from polonium. This result is consistent with the reasonable assumption that $\mathrm{H}_{2} \mathrm{O}_{2}, \mathrm{HO}_{2}$, and $\mathrm{H}$ are acting as reducing agents while $\mathrm{OH}$ acts as an oxidizing agent. $^{90}$

The alpha-particle reduction rates for ${ }^{239} \mathrm{Pu}$ are essentially independent of temperature between 5 and $45^{\circ} \mathrm{C}$ and independent of $\mathrm{HClO}_{4}$ concentration between $0.1 M$ and $3.0 M$ (Refs. 91, 93). The rates are also independent of plutonium concentration and initial oxidation number as long as $\overline{\mathrm{OX}}$ is greater than about 3.1. Apparently $\mathrm{Pu}(\mathrm{V})$ is not reduced significantly by radiolytic species but disappears by disproportionation reactions. ${ }^{86}$ Essentially the same $G$ values for reduction were observed with much higher dose rates obtained by dissolving small amounts of ${ }^{210} \mathrm{Po}$ in the solutions. ${ }^{92}$ Thus the radioly tic yields are apparently independent of alpha dose rates and can be applied to other isotopes of plutonium with different half-lives. It should be noted, however, that for the analogous autoreduction of $\mathrm{Np}(\mathrm{Vl})$ a $\mathrm{G}$ value of 6.4 atoms reduced per $100 \mathrm{eV}$ was observed. ${ }^{94}$ This large value was attributed to the fact that relatively high concentrations of neptunium were used $(0.044 M$ to $0.304 M$ ) so that reduction was occurring in the tracks, presumably reducing the hydrogen yield. This cannot be the complete explanation, because the reduction rate in a $0.04 M \mathrm{Pu}(\mathrm{IV})$ solution corresponded to $\mathrm{G}=3.5$ atoms reduced per $100 \mathrm{eV}$.

On long standing, plutonium solutions in $\mathrm{HClO}_{4}$ reach a steady state in which the rate of reduction of $\mathrm{Pu}(\mathrm{IV})$ equals the rate of oxidation of $\mathrm{Pu}(\mathrm{III})$. At $4^{\circ} \mathrm{C}$ the mean oxidation number was found to depend slightly on the total plutonium concentration, being 3.05 in $0.022 M$ solutions and 3.016 in $0.0055 M$ solutions. The steady-state $\mathrm{H}_{2} \mathrm{O}_{2}$ concentrations under these conditions were found to be $1.2 \times 10^{-3} \mathrm{~N}$ and $0.93 \times 10^{-3} \mathrm{~N}$, respectively. Under these steady-state conditions, there is a net decomposition of water and some decomposition of $\mathrm{ClO}_{4}^{-}$. Radiolytic yields in $1 \mathrm{M}$ $\mathrm{HClO}_{4}$ at $23^{\circ} \mathrm{C}$ were $\mathrm{G}_{\mathrm{H}_{2}}=0.4$ molecules of $\mathrm{H}_{2}$ per $100 \mathrm{eV}$ and $\mathrm{G}_{\mathrm{ClO}_{4}^{-}}=0.44$ molecules of $\mathrm{O}_{2}$ from $\mathrm{ClO}_{4}^{-}$per $100 \mathrm{eV}$. Chloride ion was detected in the solutions, ${ }^{93}$ and $\mathrm{ClO}_{3}^{-}$might possibly be produced also. ${ }^{95}$

The reduction of $\mathrm{Pu}(\mathrm{VI})$ in $\mathrm{H}_{2} \mathrm{SO}_{4}$ solutions is similar to that in $\mathrm{HClO}_{4}$ in that the $\mathrm{G}$ values are essentially the same (3.2). Important differences are that $\mathrm{Pu}(\mathrm{V})$ is not observed and the reduction stops at Pu(IV) (Ref. 92). This is consistent with the fact that $\mathrm{H}_{2} \mathrm{O}_{2}$ oxidizes $\mathrm{Pu}(\mathrm{III})$ rapidly to $\mathrm{Pu}(\mathrm{IV})$ in $\mathrm{H}_{2} \mathrm{SO}_{4}$. Apparently no experiments have demonstrated the alpha oxidation of $\mathrm{Pu}(\mathrm{III})$ in $\mathrm{H}_{2} \mathrm{SO}_{4}$ although this has been observed under gamma irradiation. ${ }^{92}$ Other effects of gamma and $\mathrm{X}$ irradiation have been summarized in a recent book by Cleveland. ${ }^{27}$

$\dagger$ The mean oxidation number is defined by the equation $\overline{\mathrm{ox}}=\{3[\mathrm{Pu}(\mathrm{III})]+4[\mathrm{Pu}(\mathrm{IV})]+$ $5[\mathrm{Pu}(\mathrm{V})]+6[\mathrm{Pu}(\mathrm{VI})]\} /[\Sigma \mathrm{Pu}]$. 
Early work in $\mathrm{HCl}$ solutions indicated that alpha-reduction rates were 0.2 to 0.7 as great as in $\mathrm{HClO}_{4}$ solutions. ${ }^{91}$ More-recent work ${ }^{93}$ has indicated essentialiy zero reduction rates for $\mathrm{Pu}(\mathrm{VI})$ and $\mathrm{Pu}(\mathrm{IV})$ in $1 \mathrm{M} \mathrm{HCl}$. Mixed solutions of $\mathrm{HCl}$ and $\mathrm{HClO}_{4}$ at constant acidity show that even low concentrations of chloride reduce the rates significantly. This is illustrated in Table 5.1.

Table 5.1

ALPHA REDUCTION RATES IN $1 \mathrm{M} \mathrm{HCl}-\mathrm{HClO}_{4}$ MIXTURES AT $25^{\circ} \mathrm{C}$ (Ref. 93)

\begin{tabular}{|c|c|c|c|c|c|c|}
\hline$\left[\mathrm{Cl}^{-}\right], M$ & 0.00 & 0.10 & 0.20 & 0.40 & 0.80 & 1.00 \\
\hline$-\mathrm{d}(\overline{\mathrm{OX}}) / \mathrm{dt}, \mathrm{day}^{-1}$ & 0.014 & 0.0084 & 0.007 & 0.004 & 0.0015 & 0.00 \\
\hline G, at. eq. $/ 100 \mathrm{eV}$ & 3.5 & 2.1 & 1.7 & 1.0 & 0.37 & 0.0 \\
\hline
\end{tabular}

At a constant chloride concentration of $0.1 M$, the reduction rate was found to be essentially independent of total acidity between $0.5 M$ and $2 M$, but at higher acidities the rate dropped slightly. In $0.8 \mathrm{M} \mathrm{HCl}-2.2 \mathrm{M} \mathrm{HClO}_{4}$, an initial oxidation due to the alpha irradiation was observed. In $3 \mathrm{M} \mathrm{HCl}$ solutions significant amounts of chlorine were produced, and the $\mathrm{G}$ value was found to be 0.96 molecule of $\mathrm{Cl}_{2}$ per $100 \mathrm{eV}$. Bromide ion, $0.1 M$ in $1 \mathrm{M} \mathrm{HClO}_{4}$, was also observed to lead to an increase in ox with time in $\mathrm{Pu}(\mathrm{III})-\mathrm{Pu}(\mathrm{IV})$ mixtures. ${ }^{3}$

The radiation chemistry of plutonium in nitrate solutions has been discussed extensively in a review by Miner and Seed, ${ }^{96}$ so only a brief summary will be given here.

In solutions containing $\mathrm{HNO}_{3}$ or the nitrate ion, the effect of alpha irradiation is more complicated than in $\mathrm{H}_{2} \mathrm{SO}_{4}$ or $\mathrm{HClO}_{4}$ solutions because of the formation of $\mathrm{HNO}_{2}$ and oxides of nitrogen. This probably accounts for the fact that different observers have reported different results and that inhibition periods are often observed. ${ }^{96}$ Russian chemists ${ }^{97}$ have observed initial rates of disappearance of Pu(VI) equal to about 0.016 per day in $0.05 \mathrm{M} \mathrm{NaNO}_{3}$ solution with $\mathrm{pH}$ values of either 2 or 4.7. In 0.4M $\mathrm{HNO}_{3}$, however, the rate of reduction of Pu(VI) was essentially zero at the start and increased slowly for about 20 days; finally $-\mathrm{d}(\overline{\mathrm{Ox}}) / \mathrm{dt}$ became constant at about 0.017 per day. This final rate agrees with that observed at higher $\mathrm{pH}$ values and is only slightly higher than the rates observed in $\mathrm{HClO}_{4}$ and $\mathrm{H}_{2} \mathrm{SO}_{4}$ solutions. It should be noted that other workers have observed longer inhibition periods. ${ }^{92,98}$

Increasing the nitrate concentration at a constant $\mathrm{pH}$ of 3 increases the rates significantly; a rate of 0.016 per day was found in $0.05 \mathrm{M} \mathrm{NaNO}_{3}$ and 0.033 per day in $5 M \mathrm{NaNO}_{3}$. These rates correspond to $\mathrm{G}$ values of 4 and 8 at. eq./ $100 \mathrm{eV}$, respectively. The higher value is consistent with the idea that decomposition products from $\mathrm{NO}_{3}^{-}$ play an important role. 


\section{G REACTIONS \\ O OF AMERICIUM IONS}

The kinetics of aqueous americium reactions are difficult to study because the experimental observations tend to be dominated by radiation effects. Since even the two most stable isotopes of americium, ${ }^{241} \mathrm{Am}$ and ${ }^{243} \mathrm{Am}$, have relatively short half-lives (433 and 7370 years, respectively), intense alpha-particle self-irradiation occurs in solution.

The formulas and potentials of the americium ions are given in Table 2.1. As shown in the table, the hydrated $\mathrm{Am}^{4+}$ ion is very unstable in the absence of strong complexing agents and is relatively stable only in concentrated fluoride solutions, ${ }^{99}$ concentrated phosphoric acid, or pyrophosphate solutions. ${ }^{100}$

The few oxidation-reduction reactions of americium which have been studied quantitatively are discussed here, but, since the effects of radiation are so important, they are discussed first.

\section{$6 \cdot 1$}

\section{RADIOLYTIC EFFECTS}

Radiolytic effects for americium are similar to those discussed previously for plutonium but are more pronounced. Solutions of $\mathrm{Am}$ (III), unlike those of $\mathrm{Pu}$ (III), are stable with respect to oxidation induced by alpha radiation. This is almost certainly due to the fact that the higher oxidation states of americium are much better oxidizing 
agents than are those of plutonium. The net reactions in Am(III) solutions are the decomposition of water and the production of hydrogen peroxide. Production of $\mathrm{H}_{2} \mathrm{O}_{2}$ depends on the acidity and, in $0.1 \mathrm{M}$ and $1.0 \mathrm{M} \mathrm{H}_{2} \mathrm{SO}_{4}$ solutions, corresponds to 1.2 and 0.7 molecules per $100 \mathrm{eV}$ absorbed in the solution. ${ }^{101}$ For $^{241} \mathrm{Am}$ these two values mean that the increase in $\mathrm{H}_{2} \mathrm{O}_{2}$ concentration per hour will be about 1.2 and $0.7 \%$ of the total concentration of the americium in solution.

The reduction of solutions of ${ }^{241} \mathrm{Am}(\mathrm{VI})$ occurs in two distinct stages. First $A m(V I)$ reduces to $A m(V)$, and, when the $A m(V I)$ is essentially gone, $A m(V)$ reduces to $A m(I I I)$. Since $A m(V I)$ does not react with $A m(I I I)$ and reacts relatively slowly with Am(IV), the presence of distinct stages means that Am(VI) reacts with the radiolytically produced reducing agents about 100 times faster than $A m(V)$ does. This conclusion is consistent with the fact that $\mathrm{H}_{2} \mathrm{O}_{2}$ reacts very rapidly with $\mathrm{Am}(\mathrm{VI})$ (Ref. 102) but quite slowly with Am(V) (Ref. 106).

The net reduction rate, or the change in the average oxidation number, $(\overline{\mathrm{ox}})$, with time, depends primarily on the total concentration of ${ }^{241} \mathrm{Am}$ in solution, to a lesser extent on the concentrations and nature of the acid present, and practically not at all on the relative amounts of americium in the various oxidation states. Several sets of data indicate that the net reduction rate is a few percent lower in the second stage than in the first, however. ${ }^{101.103 .104}$ Typical results from three investigations, in terms of $\mathrm{d}(\overline{\mathrm{ox}}) / \mathrm{dt}$, are summarized in Table 6.1 . The significantly larger values for the reduction-rate constant in $\mathrm{HNO}_{3}$ solutions suggest that the alpha particles react directly with $\mathrm{HNO}_{3}$ and/or the radicals react with $\mathrm{HNO}_{3}$ to produce species that change the mechanism.

Table 6.1

REDUCTION OF ${ }^{241}$ Am SOLUTIONS (k VALUES) ${ }^{a}$

\begin{tabular}{|c|c|c|c|c|c|c|c|}
\hline \multirow[b]{2}{*}{ Reaction } & \multirow[b]{2}{*}{ Acid } & \multicolumn{6}{|c|}{ Acid concentration, $M$} \\
\hline & & 0.1 & 0.2 & 1.0 & 2.0 & 4.0 & 6.0 \\
\hline \multirow[t]{2}{*}{$\operatorname{Am}(V I) \rightarrow \operatorname{Am}(V)$} & $\mathrm{HClO}_{4}$ & & $\begin{array}{l}0.0404^{b} \\
0.031^{d} \\
0.044^{d, e}\end{array}$ & $0.058^{\mathrm{c}}$ & $0.032^{b}$ & $0.032^{b}$ & $0.034^{b}$ \\
\hline & $\begin{array}{l}\mathrm{H}_{2} \mathrm{SO}_{4} \\
\mathrm{HNO}_{3}\end{array}$ & $0.0404^{b}$ & & $\begin{array}{l}0.0285^{b} \\
0.075^{b, f}\end{array}$ & $0.025^{b}$ & $\begin{array}{l}0.0202^{b} \\
0.086^{b}\end{array}$ & $\begin{array}{l}0.0180^{b} \\
0.087^{b}\end{array}$ \\
\hline $\mathrm{Am}(\mathrm{V}) \rightarrow \mathrm{Am}(\mathrm{III})$ & $\begin{array}{l}\mathrm{HClO}_{4} \\
\mathrm{H}_{2} \mathrm{SO}_{4}\end{array}$ & $0.032^{\mathrm{c}}$ & $0.024^{d}$ & $\begin{array}{l}0.046^{\mathrm{c}} \\
0.026^{\mathrm{b}, \mathrm{e}}\end{array}$ & $0.028^{b, e}$ & & \\
\hline
\end{tabular}

\footnotetext{
${ }^{\mathrm{a}}$ Reduction rate constant is defined by $\mathrm{k}=(-\mathrm{d}(\overline{\mathrm{ox}}) / \mathrm{dt}) /[\mathrm{Am}]$ total $\mathrm{hr}^{-1}$.

bef. 101 .

${ }^{c}$ Ref. 103.

def. 104.

e From graph in Ref. 101 .

$\mathrm{f}_{\mathrm{By}}$ interpolation.
} 
The alpha reduction rates given in the table are reasonable in magnitude. For example, $\mathrm{Ce}(\mathrm{IV})$ in $0.4 M \mathrm{H}_{2} \mathrm{SO}_{4}$ irradiated with alpha particles from polonium undergoes reduction at the rate of 3.2 atoms per $100 \mathrm{eV}$ absorbed. ${ }^{90}$ The analogous reduction of $\mathrm{Am}(\mathrm{VI})$ gives a value (by interpolation) of about 3.5 atoms per $100 \mathrm{eV}$. Since the agreement is satisfactory, we conclude that $\mathrm{Am}(\mathrm{VI})$ and $\mathrm{Ce}$ (IV) react in much the same way upon radiolysis of their solutions.

\section{6-2}

\section{REACTION RATES}

Most of the common reducing agents have been observed to react rapidly with either $A m(V)$ or $A m(V I)$, but very few quantitative data are available. Similarly, qualitative observations show that a variety of strong oxidizing agents react rapidly with $\mathrm{Am}(\mathrm{III})$ or $\mathrm{Am}(\mathrm{V})$. The various qualitative observations have been summarized by Gourisse. ${ }^{105}$ Quantitative kinetic data are available for only five oxidation-reduction reactions of americium; these are discussed in the following sections.

\section{6-3}

\section{THE Am(V)- $\mathrm{H}_{2} \mathrm{O}_{2}$ REACTION ${ }^{106}$}

Since $\mathrm{H}_{2} \mathrm{O}_{2}$ is one of the observed products of the radiolysis of water, we need to know its rate of reaction with $A m(V)$ and $A m(V I)$. Reaction with Am(VI) is very fast, but reaction with $\mathrm{Am}(\mathrm{V})$ is quite slow (experiments were done in $0.1 M \mathrm{HClO}_{4}$ with $\left.{ }^{241} \mathrm{Am}\right)$. The rate law is

$$
-\frac{\mathrm{d}[\mathrm{Am}(\mathrm{V})]}{\mathrm{dt}}=\mathrm{k}\left[\mathrm{AmO}_{2}^{+}\right]\left[\mathrm{H}_{2} \mathrm{O}_{2}\right]
$$

Unfortunately the hydrogen-ion dependence was not determined. The observed rate constants were $14.8 \pm 1.5,21.6 \pm 2.2$, and $30.3 \pm 3.0 \mathrm{M}^{-1} \mathrm{hr}^{-1}$ at 25,30 , and $35^{\circ} \mathrm{C}$, respectively. These values lead to an activation energy of $55 \pm 9 \mathrm{~kJ} / \mathrm{mol}$. The $\mathrm{H}_{2} \mathrm{O}_{2}$ concentrations chosen were large enough $(0.0137 \mathrm{M}$ to $0.040 \mathrm{M})$ so that the alpha reduction of the $A m(V)$ amounted to less than $10 \%$ of the observed reduction. However, the apparent second-order rate constants were observed to increase as the reaction proceeded in accordance with the known rate of alpha reduction. Correction for this effect will reduce the reported rate constants by about $10 \%$.

Thus the direct reaction between $\mathrm{Am}(\mathrm{V})$ and $\mathrm{H}_{2} \mathrm{O}_{2}$ is too slow to be important in the alpha-radiation-induced reduction of $\mathrm{Am}(\mathrm{V})$ (Ref. 101) even though about $75 \%$ of the radiolytically produced reducing equivalents are $\mathrm{H}_{2} \mathrm{O}_{2}$ (Ref. 90). The $\mathrm{H}_{2} \mathrm{O}_{2}$ is 
probably consumed by reaction with $\mathrm{Am}(\mathrm{IV})$ or with $\mathrm{Am}(\mathrm{VI})$, which is produced by the rapid reaction between $A m(I V)$ and $A m(V)$.

THE Am(VI)-H $\mathrm{H}_{2} \mathrm{O}_{2}$ REACTION

The reaction between $\mathrm{Am}$ (VI) and $\mathrm{H}_{2} \mathrm{O}_{2}$ (Ref. 102a) was studied with ${ }^{243}$ Am and stopped-flow techniques. At $25^{\circ} \mathrm{C}$ in $1 \mathrm{M}(\mathrm{H}, \mathrm{Li}) \mathrm{ClO}_{4}$, the rate is first power in both $\mathrm{Am}(\mathrm{VI})$ and $\mathrm{H}_{2} \mathrm{O}_{2}$ but shows a small inverse hydrogen-ion dependence:

$$
-\frac{\mathrm{d}[\mathrm{Am}(\mathrm{VI})]}{\mathrm{dt}}=\mathrm{k}\left[\mathrm{AmO}_{2}^{2+}\right]\left[\mathrm{H}_{2} \mathrm{O}_{2}\right]\left[\mathrm{H}^{+}\right]^{-0.12}
$$

The rate constant, $\mathrm{k}$, is $(3.91 \pm 0.06) \times 10^{4} \mathrm{M}^{-1} \mathrm{sec}^{-1}$. The hydrogen-ion dependence may indicate either a medium effect or a small contribution from a parallel path. The analogous reactions between $\mathrm{H}_{2} \mathrm{O}_{2}$ and either $\mathrm{Np}$ (VI) (Ref. 58) or Pu(VI) (Ref. 60) are predominantly inverse first power in $\left[\mathrm{H}^{+}\right]$. This difference in the hydrogen-ion dependences is consistent with the fact that Am(VI) is a much better oxidizing agent than either $\mathrm{Np}(\mathrm{VI})$ or Pu(VI). (See Chap. 4, p. 47.)

The rate constant given here can be used to estimate an upper limit for the steady-state concentration of $\mathrm{H}_{2} \mathrm{O}_{2}$ present during the alpha reduction of solutions of ${ }^{241} \mathrm{Am}(\mathrm{VI})$. Using the data from Table 6.1 for $1 M \mathrm{HClO}_{4}$ and the limiting assumption that all the $\mathrm{Am}(\mathrm{V})$ is formed by reaction with $\mathrm{H}_{2} \mathrm{O}_{2}$, we can write: $(0.058$ $\left.\mathrm{hr}^{-1}\right)[\mathrm{Am}(\mathrm{VI})]=\left(3.9 \times 10^{4} \mathrm{M}^{-1} \mathrm{sec}^{-1}\right)\left(3600 \mathrm{sec} \mathrm{hr}^{-1}\right)[\mathrm{Am}(\mathrm{VI})]\left[\mathrm{H}_{2} \mathrm{O}_{2}\right]$ and $\left[\mathrm{H}_{2} \mathrm{O}_{2}\right] \leqslant 4 \times 10^{-10} \mathrm{M}$.

6-5

OXIDATION OF Am(III) AND Am(V) BY PEROXYDISULFATE

Since peroxydisulfate is a useful reagent for preparing $A m(V)$ or $A m(V I)$ from Am(III), it is important to understand the kinetics of the reactions involved. The reactions apparently involve radicals such as $\mathrm{SO}_{4}^{-}, \mathrm{SO}_{4}^{-}$, and $\mathrm{HO}^{*}$ and are quite complicated. Two separate studies have given varying results in different Am(III) concentration ranges.

Russian investigators ${ }^{107}$ studied the reactions in $\mathrm{HNO}_{3}$ solutions using millimolar concentrations of the long-lived ${ }^{243} \mathrm{Am}$ so that radiolytic effects were negligible. The stoichiometries of the reactions are presumably

$$
3 / 2 \mathrm{~S}_{2} \mathrm{O}_{8}^{2-}+\mathrm{Am}^{3+}+2 \mathrm{H}_{2} \mathrm{O}=3 \mathrm{SO}_{4}^{2-}+\mathrm{AmO}_{2}^{2+}+4 \mathrm{H}^{+}
$$


and

$$
1 / 2 \mathrm{~S}_{2} \mathrm{O}_{8}^{2-}+\mathrm{AmO}_{2}^{+}=\mathrm{SO}_{4}^{2-}+\mathrm{AmO}_{2}^{2+}
$$

Simultaneous decomposition of $\mathrm{S}_{2} \mathrm{O}_{8}^{2-}$ is also possible, but apparently this was not investigated. The oxidations of both $\mathrm{Am}$ (III) and $\mathrm{Am}(\mathrm{V})$ show three stages: (1) a short induction period, (2) a region of constant rate, if $\mathrm{S}_{2} \mathrm{O}_{8}^{2-}$ is in excess, and (3) a region of decreasing rate. The effects of initial concentrations of americium, $\mathrm{S}_{2} \mathrm{O}_{8}^{2-}$, and $\mathrm{HNO}_{3}$ were determined for the predominantly linear parts of the reactions. Even though the ionic strength of the solutions was not held constant, the results can be summarized by the following fairly simple rate equations:

$$
-\frac{\mathrm{d}[\mathrm{Am}(\mathrm{III})]}{\mathrm{dt}}=\left(\mathrm{a}-\mathrm{b}\left[\mathrm{H}^{+}\right]\right)\left[\mathrm{S}_{2} \mathrm{O}_{8}^{2-}\right][\mathrm{Am}(\mathrm{III})]^{0}
$$

and

$$
-\frac{\mathrm{d}[\mathrm{Am}(\mathrm{V})]}{\mathrm{dt}}=\left(\mathrm{a}^{\prime}-\mathrm{b}^{\prime}\left[\mathrm{H}^{+}\right]\right)\left[\mathrm{S}_{2} \mathrm{O}_{8}^{2-}\right][\mathrm{Am}(\mathrm{V})]^{0}
$$

The rate parameters for $50.6^{\circ} \mathrm{C}$ are $\mathrm{a}=4.9 \times 10^{-5} \mathrm{~min}^{-1}, \mathrm{~b}=0.9 \times 10^{-4} \mathrm{M}^{-1} \mathrm{~min}^{-1}$, $\mathrm{a}^{\prime}=15 \times 10^{-5} \mathrm{~min}^{-1}$, and $\mathrm{b}^{\prime}=2.7 \times 10^{-4} M^{-1} \mathrm{~min}^{-1}$. Note that the americium dependences are zero and that the corresponding parameters for the two reactions differ by factors of almost exactly three. These observations indicate that Am(III) and $\mathrm{Am}(\mathrm{V})$ do not react directly with $\mathrm{S}_{2} \mathrm{O}_{8}^{2-}$ but do react rapidly with a constant fraction of the intermediates in the thermal decomposition of $\mathrm{S}_{2} \mathrm{O}_{8}^{2-}$. The unusual $\mathrm{H}^{+}$ dependence, valid only when $\mathrm{a}$ is greater than $\mathrm{b}\left[\mathrm{H}^{+}\right]$, is consistent with a plausible mechanism based on that proposed for the thermal decomposition of $\mathrm{S}_{2} \mathrm{O}_{8}^{2-}$ (Ref. 108). The rate law for this decomposition is

$$
-\frac{\mathrm{d}\left[\mathrm{S}_{2} \mathrm{O}_{8}^{2-}\right]}{\mathrm{dt}}=\left(\mathrm{k}_{1}+\mathrm{k}_{2}\left[\mathrm{H}^{+}\right]\right)\left[\mathrm{S}_{2} \mathrm{O}_{8}^{2-}\right]
$$

The acid-independent term is thought to involve the radicals $\mathrm{SO}_{4}^{--}$and $\mathrm{HO}$, which are oxidizing agents. The acid-dependent term involves $\mathrm{SO}_{4}$, which can form the reducing agent $\mathrm{H}_{2} \mathrm{O}_{2}$ by the reaction $\mathrm{SO}_{4}^{\circ}+\mathrm{H}_{2} \mathrm{O}=\mathrm{SO}_{3}+\mathrm{H}_{2} \mathrm{O}_{2}$ (Ref. 108). Thus, at an acid concentration at which the production of oxidizing agents equals the production of reducing agents, the net rate of oxidation of americium will be zero, as indicated by Eqs. 6.5 and 6.6. At $50.6^{\circ} \mathrm{C}, \mathrm{k}_{1}$ is about $6.6 \times 10^{5} \mathrm{~min}^{-1}$ (Ref. 108), and, if the intermediates for this path react quantitatively with Am(III), the stoichiometry will be given by Eq. 6.3 and the parameter a will be $2 / 3 \mathrm{k}_{1}$, or $4.4 \times 10^{-5}$, in satisfactory agreement with the observed value of $4.9 \times 10^{5} \mathrm{~min}^{-1}$. The rate parameter $b$ should 
be less than $2 / 3$ of $\mathrm{k}_{2}$ because not all the $\mathrm{SO}_{4}$ formed produces $\mathrm{H}_{2} \mathrm{O}_{2}$. The data indicate that only relatively small amounts of $\mathrm{H}_{2} \mathrm{O}_{2}$ are produced since $\mathrm{k}_{2}$ is about $2.5 \times 1 \sigma^{3} M^{1} \mathrm{~min}^{-1}$ at $50^{\circ} \mathrm{C}$ in a solution with an ionic strength of $0.7 M$ (Ref. 108) and $b$ is only $9 \times 1 \sigma^{5} M^{-1} \mathrm{~min}^{-1}$ under similar conditions.

In carbonate solutions it was found ${ }^{109}$ that the oxidation of $\mathrm{Am}(\mathrm{III})$ to $\mathrm{Am}(\mathrm{V})$ depends on the decomposition of $\mathrm{S}_{2} \mathrm{O}_{8}^{2-}$ and is independent of the concentration of americium or $\mathrm{CO}_{3}^{2-}$. The oxidation of $\mathrm{Am}(\mathrm{V})$ to $\mathrm{Am}(\mathrm{VI})$, however, was shown to be directly proportional to the concentrations of americium and $\mathrm{S}_{2} \mathrm{O}_{8}^{2-}$ but inversely proportional to the $\mathrm{K}_{2} \mathrm{CO}_{3}$ concentration.

The Japanese investigators ${ }^{10}$ studied the oxidation of ${ }^{241} \mathrm{Am}$ (III) using micromolar concentrations. Unreacted Am(III) was determined radiometrically with a lanthanum fluoride precipitation technique. A typical $\left[\mathrm{S}_{2} \mathrm{O}_{8}^{2-}\right]$-to- $[\mathrm{Am}(\mathrm{III})]$ ratio was about 5000 , and the rate of oxidation of $\mathrm{Am}$ (III) was less than $1 \%$ of the rate of decomposition of the $\mathrm{S}_{2} \mathrm{O}_{8}^{2-}$. Under these conditions the concentration of Am(III) is too low for efficient scavenging of the radicals and the rate is first power in [Am(III)] as well as in $\left[\mathrm{S}_{2} \mathrm{O}_{8}^{2-}\right]$. Silver ion catalyzes the decomposition of $\mathrm{S}_{2} \mathrm{O}_{8}^{2-}$ and also the rate of the oxidation of $\mathrm{Am}(\mathrm{III})$. At low concentrations of $\mathrm{Ag}^{+}$(less than about $\left.3 \times 1 \sigma^{4}\right)$ and at constant $\left[\mathrm{H}^{+}\right]$and ionic strength, the rate law is

$$
-\frac{\mathrm{d}[\mathrm{Am}(\mathrm{IH})]}{\mathrm{dt}}=\left(\mathrm{k}_{1}+\mathrm{k}_{2}\left[\mathrm{Ag}^{+}\right]\right)\left[\mathrm{S}_{2} \mathrm{O}_{8}^{2-}\right][\mathrm{Am}(\mathrm{III})]
$$

At $50^{\circ} \mathrm{C}$ in $0.06 M \mathrm{HNO}_{3}$ solutions with an ionic strength of $0.5 \mathrm{M}\left(\mathrm{NaNO}_{3}\right)$, $\mathrm{k}_{1}=0.093 M^{-1} \mathrm{~min}^{-1}$ and $\mathrm{k}_{2}=420 M^{-2} \mathrm{~min}^{-1}$. The activation energies associated with the two rate constants are $139 \pm 6$ and $72 \pm 2.5 \mathrm{~kJ} / \mathrm{mol}$, respectively. $\dagger$ The activation energy for the uncatalyzed decomposition of $\mathrm{S}_{2} \mathrm{O}_{8}^{2-}$ is $142 \mathrm{~kJ} / \mathrm{mol}$. The close agreement means that the fraction of the radical intermediates that react with Am(III) is essentially independent of temperature.

The effect of hydrogen-ion concentration is similar to that observed with higher americium concentrations. The rate decreases as $\left[\mathrm{H}^{+}\right]$increases (becoming zero at $0.4 M$ ), increases with decreasing $\left[\mathrm{H}^{+}\right]$, and becomes constant at about $0.06 M$.

6-6

DISPROPORTIONATION OF Am(V)

The oxidation potentials in Table 2.1 indicate that $A m(V)$ is unstable with respect to disproportionation into $\mathrm{Am}(\mathrm{III})$ and $\mathrm{Am}(\mathrm{VI})$ according to

$$
3 \mathrm{Am}(\mathrm{V})=2 \mathrm{Am}(\mathrm{VI})+\mathrm{Am}(\mathrm{III})
$$

tThese values have been recalculated from $k$ vs. T data in the original article. ${ }^{110}$ The value reported there for the $\mathrm{k}_{1}$ path $(120 \mathrm{~kJ} / \mathrm{mol})$ is clearly in error. 
In addition, if ${ }^{241} \mathrm{Am}$ is used, alpha reduction will also occur. Early experiments with this isotope in $\mathrm{HCl}$ (Ref. 111), $\mathrm{HNO}_{3}$ (Ref. 106), $\mathrm{HClO}_{4}$ (Refs. 11, 104, 106, and 112 ), and $\mathrm{H}_{2} \mathrm{SO}_{4}$ (Ref. 106) showed that reaction 6.9 occurs at measurable rates in acid solutions greater than about $2 M$. In addition, some of the data indicate that less Am(VI) is formed than is required by the equation. The rate of disappearance of $\mathrm{Am}(\mathrm{V})$ was found to be proportional to the square of its concentration and to approximately the fourth power of the acid concentration. An exact interpretation of these experiments is difficult because in most cases the alpha-reduction rate was approximately equal to the rate of disproportionation.

The most recent work ${ }^{113}$ on reaction 6.9 employed the long-lived isotope ${ }^{243} \mathrm{Am}$, so that radiolytic effects were small enough to be ignored. Changes in the concentrations of $\mathrm{Am}(\mathrm{III}), \mathrm{Am}(\mathrm{V})$, and $\mathrm{Am}(\mathrm{VI})$ were followed spectrophotometrically, and the stoichiometry was given accurately by Eq. 6.9. As expected from the much lower alpha-radiation level, the mean oxidation number decreased by only about $0.0035 \mathrm{hr}^{-1}$. As in the earlier work, the rate of disproportionation was proportional to the square of the $\mathrm{Am}(\mathrm{V})$ concentration. Thus the most probable rate-determining step is

$$
2 \mathrm{Am}(\mathrm{V})=\mathrm{Am}(\mathrm{IV})+\mathrm{Am}(\mathrm{VI})
$$

The Am(IV) formed in this way is very unstable and probably disappears by either

$$
2 \mathrm{Am}(\mathrm{IV})=\mathrm{Am}(\mathrm{III})+\mathrm{Am}(\mathrm{V})
$$

or

$$
A m(I V)+A m(V)=A m(I I I)+A m(V I)
$$

but not by both reactions. $\dagger$ It is thermodynamically possible for Am(IV) to oxidize water, but, if this were to occur to an appreciable extent, contrary to observations, the mean oxidation number would decrease. Even though the potential for reaction 6.11 is about $0.2 \mathrm{~V}$ greater than that for reaction 6.12 , it is very likely that the latter is much faster, particularly at the low Am(IV) concentrations and relatively high acid concentrations involved. (See Chap. 4). If we make this plausible assumption,

$$
-\frac{\mathrm{d}[\mathrm{Am}(\mathrm{V})]}{\mathrm{dt}}=3 \mathrm{k}[\mathrm{Am}(\mathrm{V})]^{2}
$$

where $\mathrm{k}$ is the rate constant for reaction 6.10 .

† If both reactions occur significantly, the overall reaction will not be second order in Am(V) (see Ref. 61). 
The dependence of the rate constant on the $\mathrm{HClO}_{4}$ concentration, from $3 M$ to $8 M$ at $25^{\circ} \mathrm{C}$, is given by the empirical equation

$$
3 \mathrm{k}=\left(2.25 \times 10^{-6}\right)\left[\mathrm{HClO}_{4}\right]^{5}+\left(3.3 \times 10^{-13}\right)\left[\mathrm{HClO}_{4}\right]^{13} M^{-1} \mathrm{sec}^{-1}
$$

This equation indicates an acid dependence slightly greater than fifth power. This fails to confirm the earlier, ${ }^{106}$ less precise results obtained with ${ }^{241} \mathrm{Am}$. A mechanistic interpretation of the acid dependence in these concentrated solutions is not possible, because of unknown changes in the activity coefficients of the reactants and of the water. The hydrogen-ion dependence was further examined at $75.7^{\circ} \mathrm{C}$ in $\mathrm{LiClO}_{4}-$ $\mathrm{HClO}_{4}$ solutions at a constant ionic strength of $2 \mathrm{M}$ to avoid these difficulties. Under these conditions and in $0.97 \mathrm{M}$ to $1.9 \mathrm{M}$ acid, the second-order rate constant depends on $\left[\mathrm{H}^{+}\right]^{2.5}$. This dependence suggests that two activated complexes are involved, one formed from two $\mathrm{AmO}_{2}^{+}$and two hydrogen ions and the other from two $\mathrm{AmO}_{2}^{+}$and three hydrogen ions. If these activated complexes are involved in parallel ratedetermining steps, the rate law will be

$$
-\frac{\mathrm{d}[\mathrm{Am}(\mathrm{V})]}{\mathrm{dt}}=\left[\mathrm{AmO}_{2}^{+}\right]^{2}\left(\mathrm{k}_{2}\left[\mathrm{H}^{+}\right]^{2}+\mathrm{k}_{3}\left[\mathrm{H}^{+}\right]^{3}\right)
$$

The values for $\mathrm{k}_{2}$ and $\mathrm{k}_{3}$ are $(6.94 \pm 1.01) \times 1 \sigma^{-4} M^{3} \sec ^{-1}$ and $(4.63 \pm 0.71) \times 10^{-4}$ $M^{-1} \mathrm{sec}^{-1}$, respectively. These parameters reproduce the six experimental values with a root-mean-square deviation of $3.3 \%$ and a maximum deviation of $6.5 \%$.

Despite the fact that the rate law, Eq. 6.15 , is very satisfactory, an ambiguity in interpretation remains. If the same two activated complexes are formed consecutively rather than in parallel steps, the rate law is

$$
-\frac{\mathrm{d}[\mathrm{Am}(\mathrm{V})]}{\mathrm{dt}}=\left[\mathrm{AmO}_{2}^{+}\right]^{2}\left(\frac{1}{\mathrm{k}_{2}^{\prime}\left[\mathrm{H}^{+}\right]^{2}}+\frac{1}{\mathrm{k}_{3}^{\prime}\left[\mathrm{H}^{+}\right]^{3}}\right)^{-1}
$$

This equation fits the experimental results just as well as Eq. 6.15. Values for $\mathrm{k}_{2}^{\prime}$ and $\mathrm{k}_{3}^{\prime}$ are $(2.57 \pm 0.36) \times 1 \sigma^{3} M^{3} \sec ^{-1}$ and $(2.06 \pm 0.33) \times 1 \sigma^{3} M^{-4} \mathrm{sec}^{-1}$, respectively. These values reproduce the data with a root-mean-square deviation of $3.2 \%$ and a maximum deviation of $6.6 \%$. A distinction between the two rate laws would require measurements at least down to $0.7 M \mathrm{HClO}_{4}$, where the two calculated values for the apparent second-order rate constants would differ by $10 \%$.

The temperature dependence of the disproportionation was determined for $1.92 \mathrm{M}$ $\mathrm{HClO}_{4}$ solutions from 59.6 to $85.4^{\circ} \mathrm{C}$. Since only one acid concentration was used, the data give only a single value for $\Delta H^{*}, 54 \pm 17 \mathrm{~kJ} / \mathrm{mol}$ for $\mathrm{k}_{1}$, and $54 \mp 17 \mathrm{~kJ} / \mathrm{mol}$ for $\mathrm{k}_{2}$. These estimates can probably be improved on the basis of the reasonable assumption that the difference between the two associated $\Delta S^{*}$ values is the same as for other actinide reactions. Fourteen such oxidation-reduction reactions are known for which the two activated complexes differ by one hydrogen ion. These are discussed in Chap. 9, Sec. 9-1, where it is shown that the weighted average difference is $79 \pm 9$ 
Table 6.2

NET ACTIVATION PROCESSES AND THERMODYNAMIC QUANTITIES OF ACTIVATION FOR THE DISPROPORTIONATION OF Am(V)†

\begin{tabular}{lccc}
\hline Net activation process & $\begin{array}{c}\Delta \mathrm{G}^{*}, \\
\mathrm{~kJ} / \mathrm{mol} \\
(\mathrm{kcal} / \mathrm{mol})\end{array}$ & $\begin{array}{c}\Delta \mathbf{H}^{*}, \\
\mathbf{k J} / \mathrm{mol} \\
(\mathrm{kcal} / \mathbf{m o l})\end{array}$ & $\begin{array}{c}\Delta \mathbf{S}^{*}, \\
\mathbf{J} / \mathrm{mol} \cdot \mathbf{K} \\
(\mathrm{cal} / \mathbf{m o l} \cdot \mathrm{deg})\end{array}$ \\
\hline $2 \mathrm{AmO}_{2}^{+}+2 \mathrm{H}^{+}=\left[^{*}\right]^{4+}$ & $109.5(26.17)$ & $64 \pm 1.2(15.4 \pm 0.3)$ & $-130 \pm 4(-31 \pm 1)$ \\
$2 \mathrm{AmO}_{2}^{+}+3 \mathrm{H}^{+}=\left[{ }^{*}\right]^{5+}$ & $112.2(26.81)$ & $39 \mp 2(9.4 \mp 0.5)$ & $-209 \mp 5(-50 \mp 1.2)$ \\
\hline
\end{tabular}

†Values are for $75^{\circ} \mathrm{C}$ and $\mu=2 \mathrm{M}$.

$\mathrm{J} / \mathrm{mol} \cdot \mathrm{K}$. This average value was applied to the calculation of $\Delta \mathrm{H}^{*}$ and $\Delta \mathrm{S}^{*}$ for the two net activation processes. The results are essentially the same for the parallel reaction mechanism and the consecutive reaction mechanism discussed previously and are summarized in Table 6.2.

It is of interest to compare the $\mathrm{H}^{+}$dependences for disproportionation reactions of $\mathrm{U}(\mathrm{V}), \mathrm{Np}(\mathrm{V}), \mathrm{Pu}(\mathrm{V})$, and $\mathrm{Am}(\mathrm{V})$. For this set of similar reactions, the metal-ion dependence is the same but the hydrogen-ion dependences are not. For the uranium and plutonium reactions, the free energies are negative, and rates are proportional to the first power of the hydrogen-ion concentration. On the other hand, the free energies are positive for the neptunium and americium reactions, and the hydrogen-ion dependences are significantly larger, $\left[\mathrm{H}^{+}\right]^{1.86}$ and $\left[\mathrm{H}^{+}\right]^{2.5}$, respectively. Since a total of four hydrogen ions are required for the overall reaction, these results illustrate the general idea that, the smaller the driving force for a reaction, the more the activated complex will resemble the products.

\section{6-7}

REACTION ${ }^{1} 02$ b BETWEEN Am(VI) AND Np(V)

The reaction between $\mathrm{AmO}_{2}^{2+}$ and $\mathrm{NpO}_{2}^{+}$was studied in $1 \mathrm{M}(\mathrm{H}, \mathrm{Li}) \mathrm{ClO}_{4}$ with a commercial stopped-flow apparatus. The rate is proportional to the concentrations of $\mathrm{Am}(\mathrm{VI})$ and $\mathrm{Np}(\mathrm{V})$ but is independent of $\left[\mathrm{H}^{+}\right]$between $0.1 \mathrm{M}$ and $1.0 \mathrm{M}$. Thus the rate law is

$$
-\frac{\mathrm{d}[\mathrm{Am}(\mathrm{VI})]}{\mathrm{dt}}=\mathrm{k}[\mathrm{Am}(\mathrm{VI})][\mathrm{Np}(\mathrm{V})]
$$

At $25^{\circ} \mathrm{C} \mathrm{k}$ is $(2.45 \pm 0.4) \times 10^{4} M^{-1} \mathrm{sec}^{-1}$. Measurements at three other temperatures, which range from 2.3 to $36.2^{\circ} \mathrm{C}$, give $\Delta H^{*}=27.9 \pm 0.3 \mathrm{~kJ} / \mathrm{mol}(6.66 \pm 0.08 \mathrm{kcal} / \mathrm{mol})$ and $\Delta \mathrm{S}^{*}=-67.9 \pm 1.1 \mathrm{~J} / \mathrm{mol} \cdot \mathrm{K}(-16.2 \pm 0.3 \mathrm{cal} / \mathrm{mol} \cdot \mathrm{deg})$. 


\section{EFFECT OF
IONIC STRENGTH}

Oxidation-reduction reactions of actinide ions often show rather large ionic-strength dependences. An understanding of these effects is important because we must frequently estimate the value of a rate constant at an ionic strength at which it has not been measured. It has been found that the available data are in accord with an extended form of the Debye-Hückel equation despite the high charges on the ions involved and the high ionic strengths usually used. The equation is

$$
\log \mathrm{k}=\log \mathrm{k}_{0}+\frac{\mathrm{A} \Delta \mathrm{z}^{2} \mu^{1 / 2}}{1+\mathrm{B} a \mu^{1 / 2}}+\mathrm{C} \mu
$$

where $\mu$ is the ionic strength; $\Delta \mathrm{z}^{2}$ is the change in the sum of the squares of the charges in the net activation process associated with the measured rate constant, $k ; k_{0}$, $\stackrel{\circ}{\mathrm{a}}$, and $\mathrm{C}$ are adjustable parameters; and $\mathrm{A}$ and $\mathrm{B}$ depend on the temperature, solvent, and fundamental constants. The equation is based on the assumptions that the activity coefficients of the reactants, as well as the activated complex, are given by $\log \gamma_{\mathrm{i}}=\mathrm{z}_{\mathrm{i}}^{2} \mathrm{~A} \mu^{1 / 2} /\left(1+\mathrm{Ba}_{\mathrm{i}}^{\circ} \mu^{1 / 2}\right)+\mathrm{C}_{\mathrm{i}} \mu$ and that the individual $\stackrel{\circ}{\mathrm{i}}_{\mathrm{i}}$ 's are similar enough so that some sort of average can be used for all the species involved.

As an example, the rate law for the oxidation of $\mathrm{Np}(\mathrm{III})$ by $\mathrm{Fe}(\mathrm{III})$ was found to be

$$
-\frac{\mathrm{d}[\mathrm{Np}(\mathrm{III})]}{\mathrm{dt}}=\mathrm{k}\left[\mathrm{Np}^{3+}\right]\left[\mathrm{Fe}^{3+}\right]\left[\mathrm{H}^{+}\right]^{-1}
$$


Hence the principal net activation process is

$$
\mathrm{Np}^{3+}+\mathrm{Fe}^{3+}+\mathrm{H}_{2} \mathrm{O}=[*]^{5+}+\mathrm{H}^{+}
$$

for which $\Delta \mathrm{z}^{2}=5^{2}+1^{2}-3^{2}-3^{2}=8$. The ionic strength was varied between $0.2 \mathrm{M}$ and $2.0 \mathrm{M}$; both $\mathrm{LiClO}_{4}$ and $\mathrm{NaClO}_{4}$ were used. The adjustable parameters in Eq. 7.1 were determined by a least-squares procedure. For $\mathrm{LiClO}_{4}$ solutions at $0.8^{\circ} \mathrm{C}$, the results were $\mathrm{k}_{0}=1.59 \pm 0.012 \mathrm{sec}^{-1}, \stackrel{\circ}{\mathrm{a}}=0.89 \pm 0.025 \mathrm{~nm}$, and $\mathrm{C}=0.059 \pm 0.008 \mathrm{M}^{-1}$. These parameters reproduce the eight observed values with a mean deviation of $0.8 \%$. The corresponding values for $\mathrm{NaClO}_{4}$ solutions are $1.61 \pm 0.026 \mathrm{sec}^{-1}, 0.96 \pm 0.06 \mathrm{~nm}$, and $0.051 \pm 0.016 \mathrm{M}^{-1}$; these give a mean deviation of $2 \%$. The uncertainties here are the standard deviations. It should be noted that, although a and $\mathrm{C}$ are somewhat different for the two salts, $\mathrm{k}_{0}$ is essentially the same. The data from seven other actinide reactions were treated in the same way, and in all cases Eq. 7.1 describes the ionic-strength dependences with good precision. The average values found for $\stackrel{\circ}{\text { and }} \mathrm{C}$ are summarized in Table 7.1, and the values for the individual reactions are given in Table 7.2. For a particular salt, values for both a and $\mathrm{C}$ fall within fairly narrow limits, essentially independent of $\Delta \mathrm{z}^{2}$. Thus it appears that Eq. 7.1, together with appropriate values from Table 7.1, might be used for approximate estimates for the ionic-strength dependences for reactions similar to those listed in Table 7.2.

To get an idea of how reliable such estimates might be, using the average values for $\therefore$ and $\mathrm{C}$, we calculated the ratio of the value of the rate constant at $\mu=0.2 M$ to the value at $\mu=1.0 \mathrm{M}$ for both $\mathrm{LiClO}_{4}$ and $\mathrm{NaClO}_{4}$ at $25^{\circ} \mathrm{C}$ and at $0^{\circ} \mathrm{C}$ for the various $\Delta z^{2}$ values. These ratios were then compared with the observed ratios. The average deviation was $8.2 \%$, with a range from 0.6 to $28 \%$. A similar calculation using $\mu=2 M$ and $\mu=1 M$ gave an average deviation of $8.2 \%$ and a range of 0.3 to $25 \%$.

Table 7.1 AVERAGE DEBYE-HÜCKEL PARAMETERS FOR ACTINIDE REACTIONS

$$
\log \mathrm{k}=\log \mathrm{k}_{0}+\frac{\mathrm{A} \Delta \mathrm{z}^{2} \mu^{1 / 2}}{1+B \mathbf{a} \mu^{1 / 2}}+\mathrm{C} \mu
$$

\begin{tabular}{|c|c|c|c|c|c|c|c|c|}
\hline \multirow[b]{2}{*}{$\begin{array}{c}\text { Temp., } \\
{ }^{\circ} \mathrm{C}\end{array}$} & \multirow[b]{2}{*}{$\underset{M^{-0.5}}{\mathrm{~A}}$} & \multirow[b]{2}{*}{$\begin{array}{c}\mathrm{B} \\
\mathrm{nm}^{-1} M^{-0.5}\end{array}$} & \multicolumn{2}{|c|}{$\stackrel{a}{\mathbf{a}, \mathrm{nm}}$} & \multicolumn{2}{|c|}{$\mathrm{C}, M^{-1}$} & \multicolumn{2}{|c|}{ Deviation, $\ddagger \%$} \\
\hline & & & Range & $\begin{array}{l}\text { Aver- } \\
\text { age }{ }^{\dagger}\end{array}$ & Range & $\begin{array}{l}\text { Aver- } \\
\text { age } \dagger\end{array}$ & Range & $\begin{array}{l}\text { Aver- } \\
\text { age } \dagger\end{array}$ \\
\hline \multicolumn{9}{|c|}{$\mathrm{LiClO}_{4}$} \\
\hline 25 & 0.5115 & 3.291 & $0.83-0.99$ & 0.896 & $0.021-0.173$ & 0.1275 & $1.3-7.0$ & 3.6 \\
\hline 0.5 & 0.4921 & 3.249 & $0.80-0.89$ & 0.824 & $0.059-0.148$ & 0.1009 & $0.2-2.5$ & 1.3 \\
\hline \multicolumn{9}{|c|}{$\mathrm{NaClO}_{4}$} \\
\hline 25 & 0.5115 & 3.291 & $0.83-1.07$ & 0.936 & $0-0.116$ & 0.0977 & $1.7-3.6$ & 2.8 \\
\hline 0.5 & 0.4921 & 3.249 & $0.86-0.97$ & 0.838 & $0.052-0.129$ & 0.0972 & $0.7-2.4$ & 1.7 \\
\hline
\end{tabular}

† Weighted according to the individual standard deviations.

$\$$ Mean percent deviation between observed and calculated values. 
Table 7.2 DEBYE-HÜCKEL PARAMETERS FOR EIGHT REACTIONS

\begin{tabular}{|c|c|c|c|c|c|c|c|}
\hline $\begin{array}{l}\text { Net activation } \\
\text { process }\end{array}$ & $\Delta \mathbf{z}^{2}$ & $\begin{array}{c}\text { Range of } \\
\quad \mu, M\end{array}$ & Salt & $\underset{{ }^{\circ} \mathrm{C}}{\text { Temp., }}$ & å, nm & $\mathrm{C}, M^{-1}$ & $\begin{array}{c}\text { Mean } \\
\text { deviation, \% }\end{array}$ \\
\hline $\mathrm{Fe}^{2+}+\mathrm{PuO}_{2}^{2+}=\left[{ }^{*}\right]^{4+}$ & 8 & $0.05-2.0$ & $\begin{array}{l}\mathrm{LiClO}_{4} \\
\mathrm{NaClO}_{4}\end{array}$ & $\begin{array}{l}0.1 \\
0.1\end{array}$ & $\begin{array}{l}0.821 \pm 0.016 \\
0.856 \pm 0.033\end{array}$ & $\begin{array}{l}0.1367 \pm 0.007 \\
0.1079 \pm 0.013\end{array}$ & $\begin{array}{l}1.5 \\
2.4\end{array}$ \\
\hline $\mathrm{V}^{2+}+\mathrm{UO}_{2}^{2+}=[*]^{4+}$ & 8 & $0.08-2.0$ & $\begin{array}{l}\mathrm{LiClO}_{4} \\
\mathrm{NaClO}_{4} \\
\mathrm{LiClO}_{4} \\
\mathrm{NaClO}_{4} \\
\mathrm{La}\left(\mathrm{ClO}_{4}\right)_{3}\end{array}$ & $\begin{array}{r}0.1 \\
0.1 \\
25.1 \\
25.1 \\
25.1\end{array}$ & $\begin{array}{l}0.804 \pm 0.004 \\
0.858 \pm 0.017 \\
0.833 \pm 0.016 \\
0.909 \pm 0.023 \\
1.159 \pm 0.037\end{array}$ & $\begin{array}{l}0.0988 \pm 0.0018 \\
0.0776 \pm 0.0061 \\
0.1094 \pm 0.006 \\
0.0952 \pm 0.008 \\
0.1437 \pm 0.007\end{array}$ & $\begin{array}{l}0.2 \\
0.7 \\
1.3 \\
1.7 \\
1.6\end{array}$ \\
\hline $\begin{array}{l}\mathrm{Np}^{3+}+\mathrm{Fe}^{3+}+\mathrm{H}_{2} \mathrm{O} \\
\quad=\left[{ }^{3+}\right]^{5+}+\mathrm{H}^{+}\end{array}$ & 8 & $0.2-2.0$ & $\begin{array}{l}\mathrm{LiClO}_{4} \\
\mathrm{NaClO}_{4} \\
\mathrm{LiClO}_{4} \\
\mathrm{NaClO}_{4}\end{array}$ & $\begin{array}{r}0.8 \\
0.8 \\
25.1 \\
25.1\end{array}$ & $\begin{array}{l}0.887 \pm 0.025 \\
0.957 \pm 0.058 \\
0.842 \pm 0.212 \\
0.829 \pm 0.10\end{array}$ & $\begin{array}{l}0.0591 \pm 0.008 \\
0.0515 \pm 0.0157 \\
0.0214 \pm 0.062 \\
-0.005 \pm 0.030\end{array}$ & $\begin{array}{l}0.8 \\
1.7 \\
7.0 \\
2.8\end{array}$ \\
\hline $\mathrm{Np}^{3+}+\mathrm{UO}_{2}^{2+}=\left[^{*}\right]^{5+}$ & 12 & $0.12-2.57$ & $\mathrm{LiClO}_{4}$ & 0.6 & $0.894 \pm 0.039$ & $0.148 \pm 0.015$ & 1.2 \\
\hline $\mathrm{Pu}^{3+}+\mathrm{NpO}_{2}^{2+}=\left[{ }^{*}\right]^{5+}$ & 12 & $0.24-3.2$ & $\begin{array}{l}\mathrm{LiClO}_{4} \\
\mathrm{NaClO}_{4} \\
\mathrm{La}\left(\mathrm{ClO}_{4}\right)_{3}\end{array}$ & $\begin{array}{l}0.6 \\
0.6 \\
0.6\end{array}$ & $\begin{array}{l}0.836 \pm 0.020 \\
0.969 \pm 0.031 \\
1.269 \pm 0.048\end{array}$ & $\begin{array}{l}0.140 \pm 0.006 \\
0.129 \pm 0.007 \\
0.151 \pm 0.005\end{array}$ & $\begin{array}{l}1.1 \\
1.5 \\
1.3\end{array}$ \\
\hline $\mathrm{U}^{3+}+\mathrm{UO}_{2}^{2+}=\left[{ }^{*}\right]^{5+}$ & 12 & $0.053-1.0$ & $\begin{array}{l}\mathrm{LiClO}_{4} \\
\mathrm{LiClO}_{4}\end{array}$ & $\begin{array}{r}0.8 \\
25.1\end{array}$ & $\begin{array}{l}0.884 \pm 0.019 \\
0.941 \pm 0.055\end{array}$ & $\begin{array}{l}0.139 \pm 0.02 \\
0.173 \pm 0.048\end{array}$ & $\begin{array}{l}2.5 \\
4.3\end{array}$ \\
\hline $\mathrm{Np}^{4+}+\mathrm{V}^{2+}=[*]^{6+}$ & 16 & $\begin{array}{l}0.275-3.73 \\
0.275-4.00 \\
0.275-3.90\end{array}$ & $\begin{array}{l}\mathrm{LiClO}_{4} \\
\mathrm{NaClO}_{4} \\
\mathrm{La}\left(\mathrm{ClO}_{4}\right)_{3}\end{array}$ & $\begin{array}{l}25.2 \\
25.2 \\
25.2\end{array}$ & $\begin{array}{l}0.988 \pm 0.037 \\
1.068 \pm 0.046 \\
1.141 \pm 0.061\end{array}$ & $\begin{array}{l}0.1532 \pm 0.010 \\
0.1156 \pm 0.011 \\
0.1302 \pm 0.012\end{array}$ & $\begin{array}{l}4.0 \\
3.6 \\
4.3\end{array}$ \\
\hline $\begin{array}{c}\mathrm{U}^{3+}+\mathrm{Co}\left(\mathrm{NH}_{3}\right)_{4} \\
\left(\mathrm{H}_{2} \mathrm{O}\right)_{2}^{3+}=\left[{ }^{*}\right]^{6+}\end{array}$ & 18 & $0.12-3.2$ & $\begin{array}{l}\mathrm{LiClO}_{4} \\
\mathrm{LiClO}_{4}\end{array}$ & $\begin{array}{r}0.8 \\
25.1\end{array}$ & $\begin{array}{l}0.935 \pm 0.011 \\
0.924 \pm 0.013\end{array}$ & $\begin{array}{l}0.080 \pm 0.005 \\
0.087 \pm 0.05\end{array}$ & $\begin{array}{l}1.7 \\
1.4\end{array}$ \\
\hline
\end{tabular}


The reaction between $\mathrm{Pu}^{3+}$ and the complex $\mathrm{CrOPuO}^{4+}$ differs from the reactions listed in Table 7.2 in that one of the reactants is considerably larger and that $\Delta z^{2}$ is 24. For this reaction in $\mathrm{LiClO}_{4}$ at $25^{\circ} \mathrm{C}$, the data are satisfactorily reproduced by Eq. 7.1, with $\stackrel{\circ}{=}=0.11 \pm 0.013 \mathrm{~nm}$ and $\mathrm{C}=0.233 \pm 0.006 \mathrm{M}^{-1}$ (Ref. 80). These values are considerably higher than the corresponding values given in Table 7.2 and illustrate the need for caution in estimating the parameters for Eq. 7.1. 


\section{THERMODYNAMIC QUANTITIES FOR THE OVERALL PROCESSES AND ACTIVATION PROCESSES}

The quantitative data available are summarized in Table 8.1 in terms of the overall processes, the net activation processes, and the thermodynamic quantities $(\Delta \mathrm{G}, \Delta \mathrm{H}$, and $\Delta S$ ) associated with these processes. Where possible, the overall processes were chosen to be the simplest net reactions that include the actual rate-determining steps. For example, the overall reaction

$$
\mathrm{U}(\mathrm{IV})+2 \mathrm{Fe}(\mathrm{III})=\mathrm{U}(\mathrm{IV})+2 \mathrm{Fe}(\mathrm{II})
$$

is thought to involve two net steps:

$$
\mathrm{U}(\mathrm{IV})+\mathrm{Fe}(\mathrm{III})=\mathrm{U}(\mathrm{V})+\mathrm{Fe}(\mathrm{II})
$$

and

$$
\mathrm{U}(\mathrm{V})+\mathrm{Fe}(\mathrm{III})=\mathrm{U}(\mathrm{VI})+\mathrm{Fe}(\mathrm{II})
$$

Only the first of these is rate determining, and only its properties may be kinetically important. The thermodynamic quantities for the net reactions were taken from standard sources.

The Eyring equation (Eq. 2.1) has been applied to the temperature dependence of the reaction rates to get $\Delta G^{*}, \Delta H^{*}$, and $\Delta S^{*}$. The experimental uncertainty is indicated for $\Delta S^{*}$ only. Note, however, that a corresponding uncertainty also applies to $\Delta \mathrm{H}^{*}$ since these two quantities are highly correlated. Some of the original data were recalculated for the table; references from which these data came are indicated. The data are arranged so that similar reactions appear in sets. 
Table 8.1

ACTINIDE OXIDATION-REDUCTION REACTIONS, OVERALL PROCESSES AND ACTIVATION PROCESSES

\begin{tabular}{|c|c|c|c|c|c|c|c|c|}
\hline No. & Process & $\begin{array}{l}\text { Pattern } \\
\text { (Fig. 2.1) }\end{array}$ & $\begin{array}{l}\mu, \\
\boldsymbol{M}\end{array}$ & $\begin{array}{l}\Delta \mathrm{G}, \mathrm{kJ} / \mathrm{mol} \\
(\mathrm{kcal} / \mathrm{mol})\end{array}$ & $\begin{array}{c}\Delta \mathrm{H}, \mathrm{kJ} / \mathrm{mol} \\
(\mathrm{kcal} / \mathrm{mol})\end{array}$ & $\begin{array}{c}\Delta \mathrm{S}, \mathrm{J} / \mathrm{mol} \cdot \mathrm{K} \\
(\mathrm{cal} / \mathrm{mol} \cdot \mathrm{deg})\end{array}$ & $\begin{array}{c}\mathrm{S}_{\text {complex, }}^{*} \\
\mathrm{~J} / \mathrm{mol} \cdot \mathrm{K} \\
(\mathrm{cal} / \mathrm{mol} \cdot \mathrm{deg})\end{array}$ & Ref. \\
\hline \multicolumn{9}{|c|}{ Oxidation of $\mathrm{An}^{3+}$} \\
\hline 1 & $\begin{array}{l}\mathrm{Np}^{3+}+\mathrm{Fe}^{3+}=\mathrm{Np}^{4+}+\mathrm{Fe}^{2+} \\
\mathrm{Np}^{3+}+\mathrm{Fe}^{3+}+\mathrm{H}_{2} \mathrm{O}=\left[{ }^{*}\right]^{5+}+\mathrm{H}^{+}\end{array}$ & $\begin{array}{l}\text { Net } \\
1-0\end{array}$ & 2 & $\begin{array}{r}-59.4(-14.2) \\
57.3(13.7)\end{array}$ & $\begin{array}{r}-69.0(-16.5) \\
61.1 \quad(14.6)\end{array}$ & $\begin{array}{rr}-33.5 & (-8.0) \\
12.6 \pm 1.3 \quad(3.0)\end{array}$ & $-368 \quad(-88)$ & 114 \\
\hline 2 & $\begin{array}{l}\mathrm{Pu}^{3+}+* \mathrm{Pu}^{4+}=\mathrm{Pu}^{4+}+* \mathrm{Pu}^{3+} \\
\mathrm{Pu}^{3+}+\mathrm{Pu}^{4+}+\mathrm{H}_{2} \mathrm{O}=\left[{ }^{*}\right]^{6+}+\mathrm{H}^{+}\end{array}$ & $1-0$ & 2 & $\begin{array}{rr}0.0 & (0.0) \\
56.1 & (13.4)\end{array}$ & $\begin{array}{rr}0.0 & (0.0) \\
31.0 & (7.4)\end{array}$ & $\begin{array}{rr}0.0 & (0.0) \\
-85.4 & \pm 16.7(-20.4)\end{array}$ & $-536(-128)$ & $74^{\mathrm{b}}$ \\
\hline 3 & $\begin{array}{l}\mathrm{U}^{3+}+\mathrm{UO}_{2}^{2^{+}}=\mathrm{U}^{4+}+\mathrm{UO}_{2}^{+} \\
\mathrm{U}^{3^{+}+}+\mathrm{UO}_{2}^{2+}=[]^{5+}\end{array}$ & $\begin{array}{l}\text { Net } \\
1-0\end{array}$ & 1 & $\begin{array}{r}-66.9(-16.0) \\
46.0 \quad(11.0)\end{array}$ & $\begin{array}{rr}-112.5 & (-26.9) \\
18.1 & (4.3)\end{array}$ & $\begin{array}{rr}-148.5 & (-35.5) \\
-93.3 & \pm 2.5(-22.3)\end{array}$ & $-331(-79)$ & 76 \\
\hline 4 & $\begin{array}{l}\mathrm{Np}^{3^{+}}+\mathrm{UO}_{2}^{2+}=\mathrm{Np}^{4+}+\mathrm{UO}_{2}^{+} \\
\mathrm{Np}^{3+}+\mathrm{UO}_{2}^{2+}=\left[* 1^{5+}\right. \\
\mathrm{Np}^{3+}+\mathrm{UO}_{2}^{2+}+\mathrm{H}_{2} \mathrm{O}=[*]^{4+}+\mathrm{H}^{+}\end{array}$ & $\mathrm{Net}$ & 1 & $\begin{array}{rr}8.9 & (2.1) \\
64.0 & (15.3) \\
72.4 & (17.3)\end{array}$ & $\begin{array}{rr}-37.2 & (-8.6) \\
10.9 & (2.6) \\
47.3 & (11.3)\end{array}$ & $\begin{array}{lr}-151 & (-36) \\
-178.2 \pm 2.5 & (-42.6) \\
-83.7 \pm 27.2 & (-20.0)\end{array}$ & $\begin{array}{l}-423(-101) \\
-259 \quad(-62)\end{array}$ & 12 \\
\hline 5 & $\begin{array}{l}\mathrm{Np}^{3+}+\mathrm{NpO}_{2}^{2+}=\mathrm{Np}^{4+}+\mathrm{NpO}_{2}^{+} \\
\mathrm{Np}^{3+}+\mathrm{NpO}_{2}^{2+}=[*]^{5+}\end{array}$ & $\begin{array}{c}\text { Net } \\
1-0\end{array}$ & 1 & $\begin{array}{r}-94.8(-22.6) \\
44.4(10.6)\end{array}$ & $\begin{array}{rr}-141.4 & (-33.8) \\
4.2 & (1.0)\end{array}$ & $\begin{array}{lr}-157.3 & (-37.6) \\
-133.9 \pm 4.2(-32.0)\end{array}$ & $-368 \quad(-88)$ & 76 \\
\hline 6 & $\begin{array}{l}\mathrm{Pu}^{3+}+\mathrm{NpO}_{2}^{2+}=\mathrm{Pu}^{4+}+\mathrm{NpO}_{2}^{+} \\
\mathrm{Pu}^{3+}+\mathrm{NpO}_{2}^{2+}=\left[{ }^{*}\right]^{5+} \\
\mathrm{Pu}^{3+}+\mathrm{NpO}_{2}^{2+}+\mathrm{H}_{2} \mathrm{O}=\left[{ }^{*}\right]^{4+}+\mathrm{H}^{+}\end{array}$ & Net & 1 & $\begin{array}{rr}-15.1 & (-3.6) \\
64.0 & (15.3) \\
70.3 & (16.8)\end{array}$ & $\begin{array}{rr}-60.7 & (-14.5) \\
14.6 & (3.5) \\
53.6 & (12.8)\end{array}$ & $\begin{array}{lr}-153.1 . & (-36.6) \\
-166.1 \pm 0.8(-39.7) \\
-55.6 \pm 1.7(-13.3)\end{array}$ & $\begin{array}{ll}-406 & (-97) \\
-226 & (-54)\end{array}$ & 77 \\
\hline 7 & $\begin{array}{l}\mathrm{Pu}^{3+}+\mathrm{PuO}_{2}^{2+}=\mathrm{Pu}^{4+}+\mathrm{PuO}_{2}^{+} \\
\mathrm{Pu}^{3+}+\mathrm{PuO}_{2}^{2+}=\left[{ }^{*}\right]^{5+}\end{array}$ & $\begin{array}{l}\text { Net } \\
1-0\end{array}$ & 1 & $\begin{array}{rr}6.3 & (1.5) \\
70.7 & (16.9)\end{array}$ & $\begin{array}{rr}-35.6 & (-8.5) \\
20.2 & (4.8)\end{array}$ & $\begin{array}{lr}-139.7 \\
-169.0 \pm 1.3(-40.4)\end{array}$ & $-406 \quad(-97)$ & 78 \\
\hline 8 & $\begin{array}{l}\mathrm{U}^{3+}+\mathrm{UO}_{2}^{+}+4 \mathrm{H}=2 \mathrm{U}^{4+}+2 \mathrm{H}_{2} \mathrm{O} \\
\mathrm{U}^{3+}+\mathrm{UO}_{2}^{+}+\mathrm{H}^{+}=\left[^{*}\right]^{5+}\end{array}$ & $\begin{array}{l}\text { Net } \\
2-0\end{array}$ & 1 & $\begin{array}{rr}-119.2(-28.5) \\
40.6 \quad(9.7)\end{array}$ & $\begin{array}{rr}-224.7 & (-53.7) \\
8.4 & (2.0)\end{array}$ & $\begin{array}{lr}-353.5 & (-84.5) \\
-108.8 \pm 5.4(-26.0)\end{array}$ & $-293(-70)$ & 76 \\
\hline 9 & $\begin{array}{l}\mathrm{Np}^{3+}+\mathrm{UO}_{2}^{+}+4 \mathrm{H}^{+}=\mathrm{Np}^{4+}+\mathrm{U}^{4+}+2 \mathrm{H}_{2} \mathrm{O} \\
\mathrm{Np}^{3+}+\mathrm{UO}_{2}^{+}+\mathrm{H}^{+}=\left[{ }^{*}\right]^{5+}\end{array}$ & $\begin{array}{l}\text { Net } \\
1-0\end{array}$ & 1 & $\begin{array}{r}-43.5(-10.4) \\
64.0 \quad(15.3)\end{array}$ & $\begin{array}{rr}-149.4 & (-35.7) \\
21.3 & (5.1)\end{array}$ & $\begin{array}{lr}-356 & (-85.2) \\
-142.7 \pm 5.0(-34.1)\end{array}$ & $-326(-78)$ & 12 \\
\hline 10 & $\begin{array}{l}\mathrm{Np}^{3+}+\mathrm{NpO}_{2}^{+}+4 \mathrm{H}^{+}=2 \mathrm{~Np}^{4+}+2 \mathrm{H}_{2} \mathrm{O} \\
\mathrm{Np}^{3+}+\mathrm{NpO}_{2}^{+}+\mathrm{H}^{+}=[*]^{\mathrm{s}^{+}}\end{array}$ & $\begin{array}{l}\text { Net } \\
1-0\end{array}$ & 2 & $\begin{array}{r}-56.5(-13.5) \\
63.6 \quad(15.2)\end{array}$ & $\begin{array}{rr}-172.8 & (-41.3) \\
24.7 & (5.9)\end{array}$ & $\begin{array}{lr}-391 & (-93.5) \\
-129.7 \pm 8.4(-31.0)\end{array}$ & $-314(-75)$ & 79 \\
\hline
\end{tabular}




\begin{tabular}{|c|c|c|c|c|c|c|c|c|c|c|c|}
\hline 11 & $\begin{array}{l}\mathrm{Pu}^{3+}+\mathrm{NpO}_{2}^{+}+4 \mathrm{H}^{+}=\mathrm{Pu}^{4+}+\mathrm{Np}^{4+}+2 \mathrm{H}_{2} \mathrm{O} \\
\mathrm{Pu}^{3+}+\mathrm{NpO}_{2}^{+}+\mathrm{H}^{+}=[*]^{5+}\end{array}$ & $\begin{array}{l}\text { Net } \\
1-0\end{array}$ & 1 & $\begin{array}{l}23.4 \\
99.6\end{array}$ & $\begin{array}{r}(5.6) \\
(23.8)\end{array}$ & $\begin{array}{r}-92.0 \\
49.8\end{array}$ & $\begin{array}{r}(-22.0) \\
(11.9)\end{array}$ & $\begin{array}{l}-387.0 \\
-167.4 \pm 20.9\end{array}$ & $\begin{array}{l}(-92.5) \\
(-40.0)\end{array}$ & $-356(-85)$ & $81^{c}$ \\
\hline 12 & $\begin{array}{l}\mathrm{Pu}^{3+}+\mathrm{PuO}_{2}^{+}+4 \mathrm{H}^{+}=2 \mathrm{Pu}^{4+}+2 \mathrm{H}_{2} \mathrm{O} \\
\left.\mathrm{Pu}^{3+}+\mathrm{PuO}_{2}^{+}+\mathrm{H}^{+}=1^{*}\right]^{5^{+}}\end{array}$ & $\begin{array}{l}\text { Net } \\
1.0\end{array}$ & 1 & $\begin{array}{r}-18.2 \\
80.8\end{array}$ & $\begin{array}{l}(-4.3) \\
(19.3)\end{array}$ & $\begin{array}{r}-120.9 \\
33.5\end{array}$ & $\begin{array}{r}(-28.9) \\
(8.0)\end{array}$ & $\begin{array}{l}-343.9 \\
-158.2 \pm 1.7\end{array}$ & $\begin{array}{l}(-82.2) \\
(-37.8)\end{array}$ & $-347 \quad(-83)$ & 80 \\
\hline 13 & $\begin{array}{l}\mathrm{U}^{3+}+\mathrm{Co}\left(\mathrm{NH}_{3}\right)_{4}\left(\mathrm{H}_{2} \mathrm{O}\right)_{2}^{3+}=\mathrm{U}(\mathrm{IV})+\mathrm{Co}(\mathrm{II}) \\
\mathrm{U}^{3+}+\mathrm{Co}\left(\mathrm{NH}_{3}\right)_{4}\left(\mathrm{H}_{2} \mathrm{O}\right)_{2}^{3+}=\left[{ }^{*}\right]^{6+}\end{array}$ & $\begin{array}{l}\mathrm{Net}^{\mathrm{d}} \\
1-0\end{array}$ & 2 & 54.8 & $(13.1)$ & 15.5 & $(3.7)$ & $-131.8 \pm 1.3$ & $(-31.5)$ & & 115 \\
\hline 14 & $\begin{array}{l}\mathrm{U}^{3+}+\mathrm{Co}\left(\mathrm{NH}_{3}\right)_{5} \mathrm{Cl}^{2+}=\mathrm{U}(\mathrm{IV})+\mathrm{Co}(\mathrm{II}) \\
\mathrm{U}^{3+}+\mathrm{Co}\left(\mathrm{NH}_{3}\right)_{5} \mathrm{Cl}^{2+}=[*]^{5+}\end{array}$ & $\begin{array}{l}\mathrm{Net}^{\mathrm{d}} \\
1-0\end{array}$ & 0.2 & 47.3 & $(11.3)$ & 11.3 & $(2.7)$ & $-121.3 \pm 4.2$ & $(-29.0)$ & & 18 \\
\hline 15 & $\begin{array}{l}\mathrm{U}^{3+}+\mathrm{Co}\left(\mathrm{NH}_{3}\right)_{5} \mathrm{Br}^{2+}=\mathrm{U}(\mathrm{IV})+\mathrm{Co}(\mathrm{II}) \\
\mathrm{U}^{3^{+}}+\mathrm{Co}\left(\mathrm{NH}_{3}\right)_{5} \mathrm{Br}^{2+}=[*]^{5+}\end{array}$ & $\begin{array}{l}\mathrm{Net}^{\mathrm{d}} \\
1-0\end{array}$ & 0.1 & 49.4 & $(11.8)$ & 8.4 & $(2.0)$ & $-138.1 \pm 4.2$ & $(-33.0)$ & & 18 \\
\hline 16 & $\begin{array}{l}\mathrm{Np}^{3+}+\mathrm{Ru}\left(\mathrm{NH}_{3}\right)_{5} \mathrm{OH}_{2}^{3+}=\mathrm{Np}^{4+}+ \\
\quad \mathrm{Ru}\left(\mathrm{NH}_{3}\right)_{5} \mathrm{OH}_{2}^{2+} \\
\mathrm{Np}^{3+}+\mathrm{Ru}\left(\mathrm{NH}_{3}\right)_{5} \mathrm{OH}_{2}^{3+}=[]^{6+}\end{array}$ & $\begin{array}{l}\text { Net } \\
1.0\end{array}$ & 1 & $\begin{array}{r}6.9 \\
76.1\end{array}$ & $\begin{array}{r}(1.6) \\
(18.2)\end{array}$ & $\begin{array}{r}-36.4 \\
17.7\end{array}$ & $\begin{array}{r}(-8.7) \\
(4.2)\end{array}$ & $\begin{array}{l}-145.6 \\
-196.2 \pm 3.8\end{array}$ & $\begin{array}{l}(-34.8) \\
(-46.9)\end{array}$ & & $\begin{array}{l}116 \\
116\end{array}$ \\
\hline 17 & $\begin{array}{l}\mathrm{Np}^{3+}+\mathrm{Ru}\left(\mathrm{NH}_{3}\right)_{6}^{3+}=\mathrm{Np}^{4+},+\mathrm{Ru}\left(\mathrm{NH}_{3}\right)_{6}^{2+} \\
\mathrm{Np}^{3+}+\mathrm{Ru}\left(\mathrm{NH}_{3}\right)_{6}^{3+}=\left[{ }^{*}\right]^{6^{+}}\end{array}$ & $\begin{array}{l}\text { Net } \\
1-0\end{array}$ & 0.5 & $\begin{array}{r}8.6 \\
76.1\end{array}$ & $\begin{array}{r}(2.1) \\
(18.2)\end{array}$ & $\begin{array}{r}-51.9 \\
16.3\end{array}$ & $\begin{array}{r}(-12.4) \\
(3.9)\end{array}$ & $\begin{array}{l}-202.5 \\
-201.3 \pm 14.6\end{array}$ & $\begin{array}{l}(-48.4) \\
(-48.1)\end{array}$ & & $\begin{array}{l}116 \\
116\end{array}$ \\
\hline \multicolumn{12}{|c|}{ Reduction of $\mathrm{An}^{4+}$} \\
\hline 18 & $\begin{array}{l}\mathrm{Np}^{4+}+\mathrm{V}^{2+}=\mathrm{Np}^{3+}+\mathrm{V}^{3+} \\
\mathrm{Np}^{4+}+\mathrm{V}^{2+}=[*]^{6+}\end{array}$ & $\begin{array}{l}\text { Net } \\
1-0\end{array}$ & 2 & $\begin{array}{r}-38.9 \\
70.7\end{array}$ & $\begin{array}{r}(-9.3) \\
(16.9)\end{array}$ & $\begin{array}{r}-26.8 \\
40.6\end{array}$ & $\begin{array}{r}(-6.4) \\
(9.7)\end{array}$ & $\begin{aligned} 41.8 & \\
-100.4 & \pm 0.8\end{aligned}$ & $\begin{array}{r}(10.0) \\
(-24.0)\end{array}$ & $-561^{\lfloor}(-134)$ & 117 \\
\hline 19 & $\begin{array}{l}\mathrm{Np}^{4+}+\mathrm{Cr}^{2+}=\mathrm{Np}^{3+}+\mathrm{Cr}^{3+} \\
\mathrm{Np}^{4+}+\mathrm{Cr}^{2+}+\mathrm{H}_{2} \mathrm{O}=\left[{ }^{*}\right]^{5+}+\mathrm{H}^{+} \\
\mathrm{Np}^{4+}+\mathrm{Cr}^{2+}+\mathrm{H}_{2} \mathrm{O}=\left[^{*}\right]^{4+}+2 \mathrm{H}^{+}\end{array}$ & Net & 1 & $\begin{array}{r}-54.4 \\
69.9 \\
74.1\end{array}$ & $\begin{array}{r}(-13.0) \\
(16.7) \\
(17.7)\end{array}$ & $\begin{array}{r}-44.8 \\
67.8 \\
86.2\end{array}$ & $\begin{array}{r}(-10.7) \\
(16.2) \\
(20.6)\end{array}$ & $\begin{array}{l}33.5 \\
-6.7 \pm 5.9 \\
41.0 \pm 13.8\end{array}$ & $\begin{array}{r}(8.0) \\
(-1.6) \\
(9.8)\end{array}$ & $\begin{array}{ll}-402 & (-96) \\
-356 & (-85)\end{array}$ & $118^{b}$ \\
\hline 20 & $\begin{array}{l}\mathrm{Pu}^{4+}+\mathrm{Fe}^{2+}=\mathrm{Pu}^{3+}+\mathrm{Fe}^{3+} \\
\mathrm{Pu}^{4+}+\mathrm{Fe}^{2+}+\mathrm{H} \mathrm{O}=[*]^{5+}+\mathrm{H}^{+}\end{array}$ & Net & & $\begin{array}{r}-20.5 \\
632\end{array}$ & $(-4.9)$ & -12.6 & $(-3.0)$ & 29.3 & $(7.0)$ & & \\
\hline 21 & $\begin{array}{l}\mathrm{Pu}^{4+}+\mathrm{Fe}^{2+}+\mathrm{H}_{2} \mathrm{O}= \\
\mathrm{Pu}^{4+}+\mathrm{V}^{3+}+\mathrm{H}_{2} \mathrm{O}=\mathrm{Pu}^{3+}+\mathrm{VO}^{2+}+2 \mathrm{H}^{+} \\
\mathrm{Pu}^{4+}+\mathrm{V}^{3+}+\mathrm{H}_{2} \mathrm{O}=\left[{ }^{*}\right]^{6+}+\mathrm{H}^{+} \\
\mathrm{Pu}^{4+}+\mathrm{V}^{3+}+\mathrm{H}_{2} \mathrm{O}=\left[{ }^{*}\right]^{5+}+2 \mathrm{H}^{+}\end{array}$ & Net & 2 & $\begin{array}{r}63.2 \\
-59.8 \\
65.7 \\
64.0\end{array}$ & $\begin{array}{r}(15.1) \\
(-14.3) \\
(15.7) \\
(15.3)\end{array}$ & $\begin{array}{l}79.9 \\
12.6 \\
72.0 \\
90.4\end{array}$ & $\begin{array}{r}(19.1) \\
(17.2) \\
(21.6)\end{array}$ & $\begin{array}{l}54.4 \pm 4.2 \\
246.9 \\
20.9 \pm 12.6 \\
87.9 \pm 8.4\end{array}$ & $\begin{array}{r}(13.0) \\
(59.0) \\
(21.0) \\
(21.0)\end{array}$ & $\begin{array}{l}-360(-86) \\
-523(-125) \\
-456(-109)\end{array}$ & 44 \\
\hline 22 & $\begin{array}{l}\mathrm{Pu}^{4+}+\mathrm{Ti}^{3+}+\mathrm{H}_{2} \mathrm{O}=\mathrm{Pu}^{3+}+\mathrm{TiO}^{2+}+2 \mathrm{H}^{+} \\
\mathrm{Pu}^{4+}+\mathrm{Ti}^{3+}+\mathrm{H}_{2} \mathrm{O}=\left[{ }^{*}\right]^{6+}+\mathrm{H}^{+}\end{array}$ & $\begin{array}{l}\text { Net } \\
1-0\end{array}$ & 1 & $\begin{array}{r}-84.9 \\
62.8\end{array}$ & $\begin{array}{r}(-20.3) \\
(15.0)\end{array}$ & $\begin{array}{r}-1.3 \\
69.9\end{array}$ & $\begin{array}{r}(-0.3) \\
(16.7)\end{array}$ & $\begin{array}{l}280.3 \\
25.1 \pm 8.4\end{array}$ & $\begin{array}{r}(67.0) \\
(6.0)\end{array}$ & $-515(-123)$ & 120 \\
\hline
\end{tabular}


Table 8.1 (Continued)

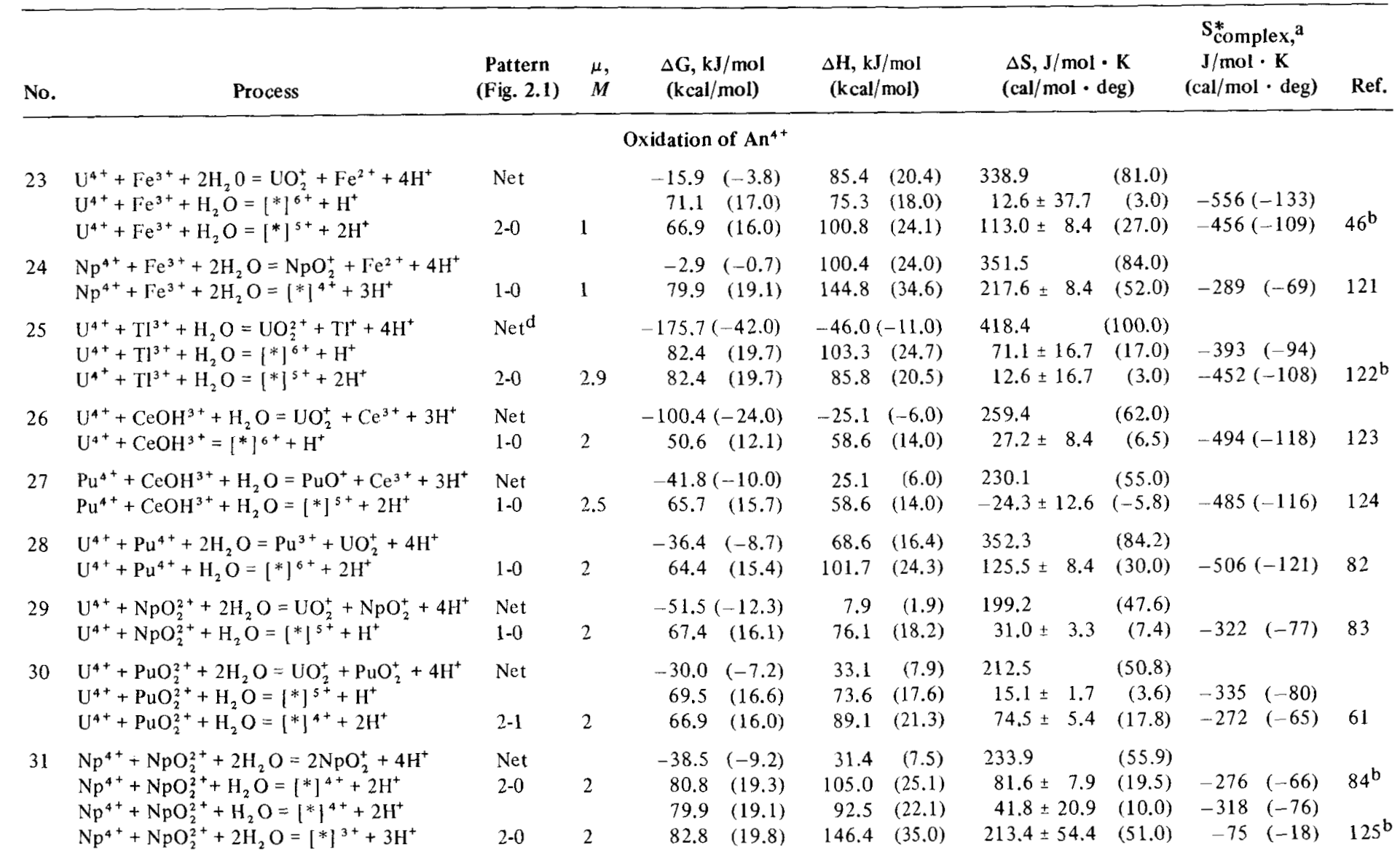


$32 \mathrm{~Np}^{4+}+\mathrm{PuO}_{2}^{2+}+2 \mathrm{H}_{2} \mathrm{O}=\mathrm{NpO}_{2}^{+}+$ $\mathrm{PuO}_{2}^{+}+4 \mathrm{H}^{+}$
$\mathrm{Np}^{4+}+\mathrm{PuO}_{2}^{2+}+\mathrm{H}_{2} \mathrm{O}=[*]^{4+}+2 \mathrm{H}^{+}$

$33 \mathrm{U}^{4+}+* \mathrm{UO}_{2}^{2+}=\mathrm{UO}_{2}^{2+}+* \mathrm{U}^{4+}$ $2 \mathrm{U}^{4+}+\mathrm{UO}_{2}^{2+}+2 \mathrm{H}_{2} \mathrm{O}=\left[^{*}\right]^{6+}+4 \mathrm{H}^{+}$

$34 \mathrm{~Np}^{4+}+* \mathrm{NpO}_{2}^{+}=\mathrm{NpO}_{2}^{+}+* \mathrm{~Np}^{4+}$ $\mathrm{Np}^{4+}+\mathrm{NpO}_{2}^{2+}+\mathrm{H}_{2} \mathrm{O}=[*]^{4+}+2 \mathrm{H}^{+}$ $2 \mathrm{NpO}_{2}^{+}+\mathrm{H}^{+}=[*]^{3^{+}}$

$35 \quad 5 \mathrm{Pu}^{4+}+2 \mathrm{MnO}_{4}^{-}+2 \mathrm{H}_{2} \mathrm{O}=5 \mathrm{PuO}_{2}^{2+}+$ $2 \mathrm{Mn}^{2+}+4 \mathrm{H}^{+}$

$\mathrm{Pu}^{4+}+\mathrm{Mn}^{2+}+\mathrm{H}_{2} \mathrm{O}=[*]^{4+}+2 \mathrm{H}^{+}$

$362 \mathrm{UO}_{2}^{+}+4 \mathrm{H}^{+}=\mathrm{U}^{4+}+\mathrm{UO}_{2}^{2+}+2 \mathrm{H}_{2} \mathrm{O}$ $2 \mathrm{UO}_{2}^{+}+\mathrm{H}^{+}=\left[{ }^{*}\right]^{3+}$

$37 \quad 2 \mathrm{PuO}_{2}^{+}+4 \mathrm{H}^{+}=\mathrm{Pu}^{4+}+\mathrm{PuO}_{2}^{2+}+2 \mathrm{H}_{2} \mathrm{O}$ $2 \mathrm{PuO}_{2}^{+}+\mathrm{H}^{+}=\left[{ }^{*}\right]^{3+}$

$382 \mathrm{AmO}_{2}^{+}+4 \mathrm{H}^{+}=\mathrm{Am}^{4+}+\mathrm{AmO}_{2}^{2+}+2 \mathrm{H}_{2} \mathrm{O} \quad \mathrm{Ne}$ $2 \mathrm{AmO}_{2}^{+}+2 \mathrm{H}^{+}=[*]^{4+}$ $2 \mathrm{AmO}_{2}^{+}+3 \mathrm{H}^{+}=[*]^{5+}$

Net $\quad-17.2 \quad(-4.1) \quad 56.5 \quad(13.5) \quad 247.3 \quad 0 \quad(59.1)$

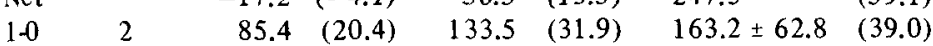

$\begin{array}{lllllll}\text { Net } & 0.0 & (0.0) & 0.0 & (0.0) & 0.0 & (0.0)\end{array}$

$1-0$

$0.14 \quad 105.0 \quad(25.1)$

$137.2(32.8)$

108.8 $\begin{array}{ll}0.0 & (0.0)\end{array}$ $66.9(16.0)$ $101.3(24.2)$

\section{$0.0 \quad(0.0)$}

$83.3(19.9)$

$73.6 \quad(17.6)$

\section{0}

$130.1 \pm 7.1 \quad(31.1)$

$-92.9 \pm 2.9(-22.2)$ $-192(-46) \quad 87$

$62.8(15.0)$

$90.8 \quad(21.7)$

$94.1 \pm 4.2$

(22.5)

$-310(-74)$

\section{Reduction of $\mathrm{AnO}_{2}^{+}$}

Net

$2-1$

Net

$1-0$

2

$-52.3(-12.5)$

$\begin{array}{rrr}-112.1 & (-26.8) & -205.0 \\ 46.0 & (11.0) & -46.0 \pm\end{array}$

$(-49.0)$

$2 \quad 59.8 \quad(14.3)$

$46.0 \quad(11.0) \quad-46.0 \pm 6.3(-11.0)$

$-24.5 \quad(-5.8)$

$87.0 \quad(20.8)$

$-85.4(-20.4)-204.2$

$(-48.8)$

$78.7 \quad(18.8) \quad-25.1 \pm 37.7 \quad(-6.0)$

$\begin{array}{lllll}18.4 & (4.4) & -41.8(-10.0) & -209.2 \quad(-50.0)\end{array}$

$102.1 \quad(24.4) \quad 53.6(12.8)-161.1 \pm 54.4(-38.5)$

$102.9 \quad(24.6) \quad 53.3 \quad(12.7)-168.6 \pm 54.4(-40.3)$

$-138(-33)$

2

$-110.5(-26.4)$ $66.5 \quad(15.9)$

$-213.4(-51.0)-351.5$

$(-84.0)$

$\begin{array}{lll}31.8 & (7.6)-117.2 \pm 54.4(-28.0)\end{array}$ $\left.\mathrm{NpO}^{+}+\mathrm{Cr}^{2+}={ }^{*}\right]^{3+}$

$\mathrm{NpO}_{2}^{+}+\mathrm{Cr}^{2+}+\mathrm{H}^{+}=[*]^{4+}$

$40 \quad \mathrm{NpO}_{2}^{+}+\mathrm{V}^{3+}+2 \mathrm{H}^{+}=\mathrm{Np}^{4+}+\mathrm{VO}^{2+}+\mathrm{H}_{2} \mathrm{O}$ $\mathrm{NpO}_{2}^{+}+\mathrm{V}^{3+}=\left[{ }^{*}\right]^{4+}$

$41 \quad \mathrm{NpO}_{2}^{+}+\mathrm{U}^{4+}=\mathrm{Np}^{++}+\mathrm{UO}_{2}^{+}$ $\mathrm{NpO}_{2}^{+}+\mathrm{U}^{4+}+\mathrm{H}_{2} \mathrm{O}=\left[{ }^{*}\right]^{3+}+2 \mathrm{H}^{+}$

$36.8(-8.8)$

$76.1 \quad(18.2)$

7.9

$-75.3(-18.0)-125.5$

$(-30.0)$

$-15.9(-3.8)$

$102.1(24.4)$

$61.1(14.6) \quad-51.5 \pm 10.9(-12.3)$

$-25.1 \quad(-6.0) \quad-33.5$

$(-8.0)$

$-104.6(-25.0)$

$32.2 \quad(31.6)$

104.6

$(-68.0)$

$\left.\mathrm{CrUO}_{2}^{4+}+\mathrm{Cr}^{2+}=1^{*}\right]^{6+}$

$57.1(13.6)$

(-45.0) -284.5

$2(-35.2)$

$\begin{array}{llllll}-23.4 & (-5.6) & -108.8 & (26.0) & -284.5 & (-68.0)\end{array}$

$63.6 \quad(15.2)$

$8(-36.4)$ 
Table 8.1 (Continued)

\begin{tabular}{|c|c|c|c|c|c|c|c|c|c|}
\hline No. & Process & $\begin{array}{c}\text { Pattern } \\
\text { (Fig. 2.1) }\end{array}$ & $\begin{array}{l}\mu, \\
M\end{array}$ & $\begin{array}{l}\Delta \mathrm{G}, \mathrm{kJ} / \mathrm{mol} \\
(\mathrm{kcal} / \mathrm{mol})\end{array}$ & $\begin{array}{c}\Delta \mathrm{H}, \mathrm{kJ} / \mathrm{mol} \\
(\mathrm{kcal} / \mathrm{mol})\end{array}$ & $\begin{array}{l}\Delta \mathrm{S}, \mathrm{J} / \mathrm{mol} \cdot \mathrm{K} \\
(\mathrm{cal} / \mathrm{mol} \cdot \mathrm{deg})\end{array}$ & $\begin{array}{r}\mathrm{S}_{\mathrm{com}}^{*} \\
\mathrm{~J} / \mathrm{mo} \\
\text { (cal } / \mathrm{mc}\end{array}$ & $\begin{array}{l}\text { plex, } \\
1 \cdot K \\
1 \cdot \operatorname{deg})\end{array}$ & Ref. \\
\hline \multicolumn{10}{|c|}{ Oxidation of $\mathrm{AnO}_{2}^{+}$} \\
\hline 44 & $\begin{array}{l}\mathrm{NpO}_{2}^{+}+\mathrm{CeOH}^{3+}+\mathrm{H}^{+}=\mathrm{NpO}_{2}^{2+}+ \\
\mathrm{Ce}^{3+}+\mathrm{H}_{2} \mathrm{O} \\
\left.\mathrm{NpO}_{2}^{+}+\mathrm{CeOH}^{3+}+\mathrm{H}^{+}=[]^{*}\right]^{5+}\end{array}$ & $\begin{array}{l}\text { Net } \\
1-0\end{array}$ & 2 & $\begin{array}{r}-55.6(-13.3) \\
44.8 \quad(10.7)\end{array}$ & $\begin{array}{r}-46.0(-11.0) \\
0.0 \quad(0.0)\end{array}$ & $\begin{array}{rr}29.3 & (7.0) \\
-150.6 \pm 20.9 & (-36.0)\end{array}$ & -351 & $(-84)$ & 129 \\
\hline 45 & $\begin{array}{l}\mathrm{NpO}_{2}^{+}+\mathrm{Co}^{3+}=\mathrm{NpO}_{2}^{2+}+\mathrm{Co}^{2+} \\
\mathrm{NpO}_{2}^{+}+\mathrm{Co}^{3+}=\left[{ }^{*}\right]^{4+} \\
\mathrm{NpO}_{2}^{+}+\mathrm{Co}^{3+}+\mathrm{H}_{2} \mathrm{O}=\left[{ }^{*}\right]^{3+}+\mathrm{H}^{+} \\
\text {or }\end{array}$ & Net & 2 & $\begin{aligned} &-67.4(-16.1) \\
& 59.0 \quad(14.1) \\
& 64.4 \quad(15.4)\end{aligned}$ & $\begin{array}{rr}-33.5 & (-8.0) \\
50.2 & (12.0) \\
82.4 & (19.7)\end{array}$ & $\begin{array}{lr}117.2 & (28.0) \\
-29.3 \pm 3.3 & (-7.0) \\
60.7 \pm 34.3 \quad(14.5)\end{array}$ & $\begin{array}{l}-351 \\
-192\end{array}$ & $\begin{array}{l}(-84) \\
(-46)\end{array}$ & \\
\hline & $\mathrm{NpO}_{2}^{+}+\mathrm{Co}^{3+}=[*]^{4+}$ & $1-0^{f}$ & 2 & $58.3 \quad(13.9)$ & $56.1 \quad(13.4)$ & $-7.1 \pm 15.5 \quad(-1.7)$ & & $(-79)$ & $47^{\mathrm{b}}$ \\
\hline 46 & $\begin{array}{l}\mathrm{CrNpO}_{2}^{4+}+\mathrm{Co}^{3+}=\mathrm{NpO}_{2}^{2+}+\mathrm{Co}^{2+}+\mathrm{Cr}^{3+} \\
\mathrm{CrNpO}_{2}^{4+}+\mathrm{Co}^{3+}+\mathrm{H}_{2} \mathrm{O}=\left[{ }^{*}\right]^{6+}+\mathrm{H}^{+}\end{array}$ & $\begin{array}{l}\text { Net } \\
1-0^{f}\end{array}$ & 2.1 & $\begin{aligned}-71.1(-17.0) \\
70.8 \quad(16.9)\end{aligned}$ & $\begin{array}{rr}-20.9 & (-5.0) \\
77.4 & (18.5)\end{array}$ & $\begin{array}{rr}175.7 & (42.0) \\
22.6 \pm 15.9 & (5.4)\end{array}$ & -565 & $(-135)$ & $47^{\mathrm{b}}$ \\
\hline 47 & $\begin{array}{l}\mathrm{NpO}_{2}^{+}+\mathrm{NpO}_{2}^{2+}=\mathrm{NpO}_{2}^{2+}+* \mathrm{NpO}_{2}^{+} \\
\mathrm{NpO}_{2}^{+}+\mathrm{NpO}_{2}^{2+}=\left[{ }^{*}\right]^{3^{+}}\end{array}$ & $\begin{array}{l}\text { Net } \\
2-0\end{array}$ & 3 & $\begin{array}{rr}0.0 & (0.0) \\
58.6 & (14.0)\end{array}$ & $\begin{array}{rr}0.0 & (0.0) \\
44.4 & (10.6)\end{array}$ & $\begin{array}{cr}0.0 & (0.0) \\
-50.2 & \pm 12.6(-12.0)\end{array}$ & -151 & $(-36)$ & 75 \\
\hline 48 & $\begin{array}{l}\mathrm{NpO}_{2}^{+}+\mathrm{AmO}_{2}^{2+}=\mathrm{NpO}_{2}^{2+}+\mathrm{AmO}_{2}^{+} \\
\left.\mathrm{NpO}_{2}^{+}+\mathrm{AmO}_{2}^{2+}=[]^{*}\right]^{3^{+}}\end{array}$ & $\begin{array}{l}\text { Net } \\
1-0\end{array}$ & 1 & $\begin{array}{rr}-38.4 & (-9.2) \\
48.1 & (11.5)\end{array}$ & $\begin{array}{rr}-37.0 & (-9) \\
27.9 & (6.7)\end{array}$ & $\begin{array}{cr}6 . & (1.4) \\
-67.9 \pm & 1.1(-16.2)\end{array}$ & -172 & $(-41)$ & $101 t$ \\
\hline \multicolumn{10}{|c|}{ Reduction of $\mathrm{AnO}_{2}^{2+}$} \\
\hline 49 & $\begin{array}{l}\mathrm{UO}_{2}^{2+}+\mathrm{Cr}^{2+}=\mathrm{CrUO}_{2}^{4+} \\
\mathrm{UO}_{2}^{2+}+\mathrm{Cr}^{2+}=\left[1^{*}\right]^{4+}\end{array}$ & $\begin{array}{l}\text { Net } \\
1-0\end{array}$ & & $\begin{array}{lr}-4.2 & (-1.0) \\
49.4 & (11.8)\end{array}$ & $\begin{array}{rr}-100.4 & (-24.0) \\
2.1 & (0.5)\end{array}$ & $\begin{array}{l}-192.5 \quad(-46.0) \\
-159.0 \pm 6.3(-38.0)\end{array}$ & -356 & $(-85)$ & 130 \\
\hline 50 & $\begin{array}{l}\mathrm{UO}_{2}^{2+}+\mathrm{Eu}^{2+}=\mathrm{UO}_{2}^{+}+\mathrm{Eu}^{3+} \\
\mathrm{UO}_{2}^{2+}+\mathrm{Eu}^{2+}=[]^{4+}\end{array}$ & $\begin{array}{l}\text { Net } \\
1-0\end{array}$ & 2 & $\begin{array}{rr}-39.7 & (-9.5) \\
49.4 & (11.8)\end{array}$ & $\begin{aligned}-87.9 & (-21.0) \\
6.3 & (1.5)\end{aligned}$ & $\begin{array}{lr}-159.0 & (-38.0) \\
-143.9 \pm 4.2(-34.4)\end{array}$ & -218 & $(-52)$ & 131 \\
\hline 51 & $\begin{array}{l}\mathrm{UO}_{2}^{2+}+\mathrm{V}^{2+}=\mathrm{UO}_{2+}^{+}+\mathrm{V}^{3+} \\
\mathrm{UO}_{2}^{2+}+\mathrm{V}^{2+}=[]^{*+}\end{array}$ & $1-0$ & 2 & $\begin{array}{rr}-30.5 & (-7.3) \\
62.3 & (14.9)\end{array}$ & $\begin{aligned}-62.8(-15.0) \\
29.7 \quad(7.1)\end{aligned}$ & $\begin{array}{lr}-108.8 & (-26.0) \\
-109.2 \pm 1.7(-26.1)\end{array}$ & -301 & $(-72)$ & 49 \\
\hline 52 & $\begin{array}{l}\mathrm{PuO}_{2}^{2+}+\mathrm{Fe}^{2+}=\mathrm{PuO}_{2}^{+}+\mathrm{Fe}^{3+} \\
\mathrm{PuO}_{2}^{2+}+\mathrm{Fe}^{2+}=[*]^{4^{+}} \\
\mathrm{PuO}_{2}^{2+}+\mathrm{Fe}^{2+}=[*]^{4+} \\
\mathrm{PuO}_{2}^{2+}+\mathrm{Fe}^{2+}+\mathrm{H}_{2} \mathrm{O}=\left[{ }^{*}\right]^{3+}+\mathrm{H}^{+}\end{array}$ & Net & 2 & $\begin{array}{rr}-13.8 & (-3.3) \\
55.6 & (13.3) \\
51.9 & (12.4) \\
56.1 & (13.4)\end{array}$ & $\begin{array}{rr}-48.1 & (-11.5) \\
18.4 & (4.4) \\
36.0 & (8.6) \\
39.3 & (9.4)\end{array}$ & $\begin{array}{rr}-117.2 & (-28.0) \\
-125.5 & \pm 6.7(-30.0) \\
-52.7 \pm & 8.4(-12.6) \\
-56.1 \pm & 8.4(-13.4)\end{array}$ & $\begin{array}{l}-335 \\
-264 \\
-197\end{array}$ & $\begin{array}{l}(-80) \\
(-63) \\
(-47)\end{array}$ & 62 \\
\hline
\end{tabular}




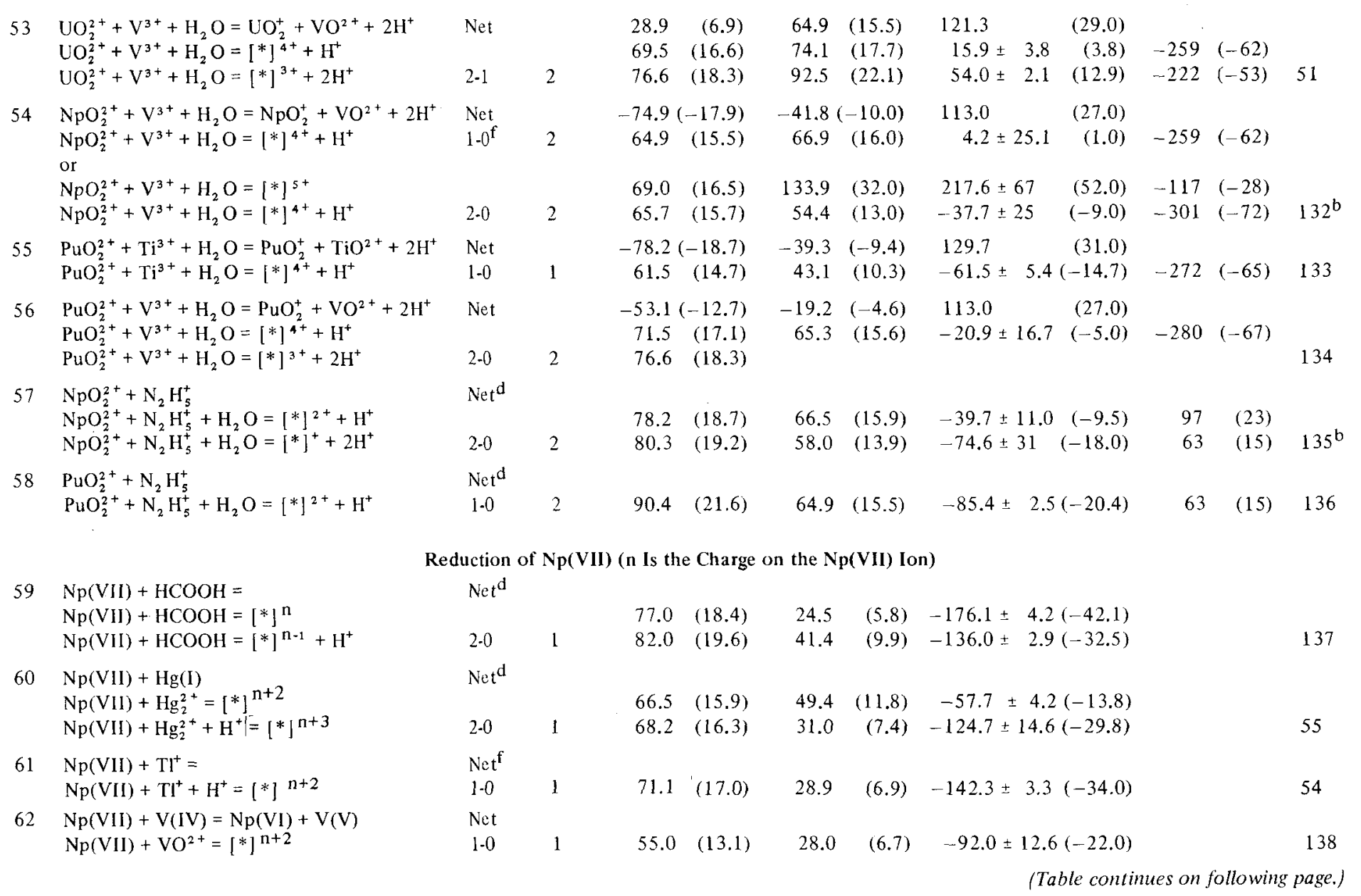


Table 8.1 (Continued)

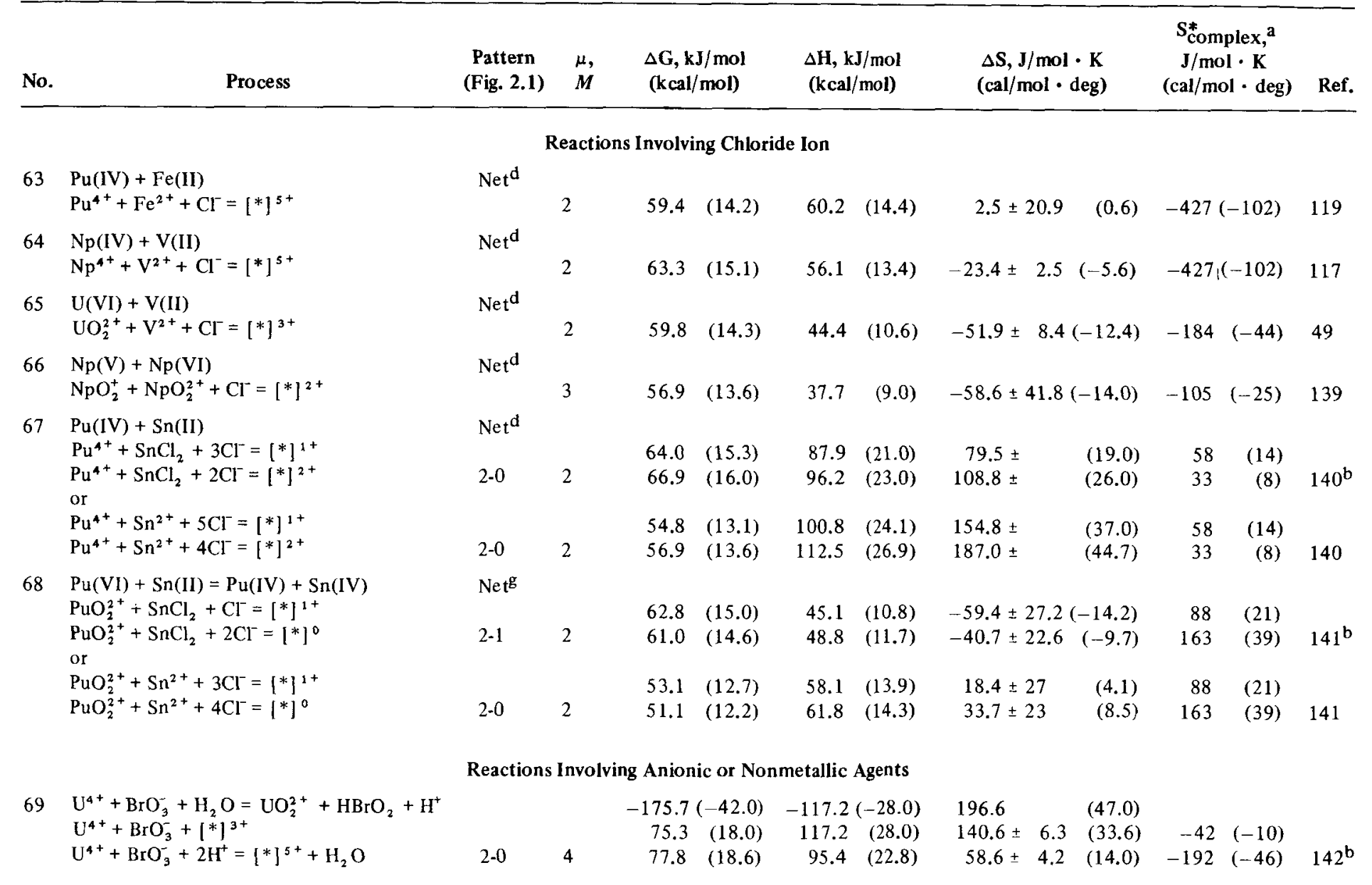




\begin{tabular}{|c|c|c|c|c|c|c|c|c|c|c|c|c|}
\hline 70 & $\begin{array}{l}3 \mathrm{U}(\mathrm{IV})+2 \mathrm{Cr}(\mathrm{VI})=3 \mathrm{U}(\mathrm{VI})+2 \mathrm{Cr}(\mathrm{HI}) \\
\mathrm{U}^{4+}+\mathrm{HCrO}_{4}^{-}=[]^{2+}+\mathrm{H}^{+}\end{array}$ & Net & & 45.1 & $(10.8)$ & 55.6 & (13.3) & $35.6 \pm 20.9$ & $(8.5)$ & -126 & $(-30)$ & 67 \\
\hline 71 & $\begin{array}{l}\mathrm{NpO}_{2}^{+}+\mathrm{HCrO}_{4}^{-}=\mathrm{NpO}_{2}^{2+}+\mathrm{Cr}(\mathrm{V}) \\
\mathrm{NpO}_{2}^{+}+\mathrm{HCrO}_{4}^{-}+2 \mathrm{H}^{+}=[*]^{2+}+\mathrm{H}_{2} \mathrm{O} \\
2 \mathrm{NpO}_{2}^{+}+\mathrm{HCrO}_{4}^{-}+4 \mathrm{H}^{+}=\left[^{*}\right]^{3+}+ \\
\mathrm{NpO}_{2}^{2+}+2 \mathrm{H}_{2} \mathrm{O}\end{array}$ & Net & 2 & 71.1 & $(16.8)$ & 47.7 & $(11.4)$ & $\begin{array}{l}-49.0 \pm 4.2 \\
-78.2 \pm 12.6\end{array}$ & $(-11.7)$ & 38 & $(0)$ & 143 \\
\hline 72 & $\begin{array}{l}\mathrm{U}^{4+}+\mathrm{HClO}_{2}+\mathrm{H}_{2} \mathrm{O}=\mathrm{UO}_{2}^{2+}+\mathrm{HOCl}+2 \mathrm{H}^{+} \\
\mathrm{U}^{4+}+\mathrm{HClO}_{2}=\left[{ }^{*}\right]^{3+}+\mathrm{H}^{+}\end{array}$ & $\begin{array}{l}\text { Net } \\
1-0\end{array}$ & 2 & $\begin{array}{r}-252.3( \\
66.5\end{array}$ & $\begin{array}{r}-60.3) \\
(15.9)\end{array}$ & $\begin{array}{c}-205.9 \\
86.2\end{array}$ & $\begin{array}{r}-49.2) \\
(20.6)\end{array}$ & $\begin{array}{r}140.2 \\
66.5 \pm 6.3\end{array}$ & $\begin{array}{l}(33.5) \\
(15.9)\end{array}$ & -92 & $(-22)$ & $65^{\mathrm{b}}$ \\
\hline 73 & $\begin{array}{c}\mathrm{U}^{4^{+}}+\mathrm{Fe}(\mathrm{CN})_{6}^{3-}+2 \mathrm{H}_{2} \mathrm{O}=\mathrm{UO}_{2}^{+}+ \\
\mathrm{Fe}(\mathrm{CN})_{6}^{4-}+4 \mathrm{H}^{+} \\
\mathrm{U}^{4^{+}}+\mathrm{Fe}(\mathrm{CN})_{6}^{3-}+\mathrm{H}_{2} \mathrm{O}=\left[{ }^{*}\right]^{0}+\mathrm{H}^{+}\end{array}$ & $1-0$ & 2 & $\begin{array}{l}12.1 \\
70.3\end{array}$ & $\begin{array}{r}(2.9) \\
(16.8)\end{array}$ & 70.7 & $(16.9)$ & $1.7 \pm 8.4$ & $(0.4)$ & 42 & $(10)$ & $144^{\mathrm{b}}$ \\
\hline 74 & $\begin{array}{l}\mathrm{PuO}_{2}^{2+}+\mathrm{H}_{2} \mathrm{O}_{2}=\mathrm{PuO}_{2}^{+}+\mathrm{HO}_{2}+\mathrm{H}^{+} \\
\mathrm{PuO}_{2}^{2+}+\mathrm{H}_{2} \mathrm{O}_{2}=[]^{1^{+}+\mathrm{H}^{+}}\end{array}$ & $\begin{array}{l}\text { Net } \\
1-0\end{array}$ & 1 & $\begin{array}{r}-56.5 \\
85.8\end{array}$ & $\begin{array}{r}(-13.5) \\
(20.5)\end{array}$ & 47.7 & $(11.4)$ & $\pm 12.6 \pm 12.6$ & $(-30.0)$ & -54 & $(-13)$ & 60 \\
\hline 75 & $\begin{array}{l}\mathrm{NpO}_{2}^{2+}+\mathrm{H}_{2} \mathrm{O}_{2}=\mathrm{NpO}_{2}^{+}+\mathrm{HO}_{2}+\mathrm{H}^{+} \\
\left.\mathrm{NpO}_{2}^{2+}+\mathrm{H}_{2} \mathrm{O}_{2}={ }^{*}\right]^{1^{+}}+\mathrm{H}^{+} \\
2 \mathrm{NpO}_{2}^{2+}+\mathrm{H}_{2} \mathrm{O}_{2}=[*]^{2+}+\mathrm{NpO}_{2}^{+}+\mathrm{H}^{+}\end{array}$ & Net & 3 & $\begin{array}{l}35.1 \\
69.5 \\
71.1\end{array}$ & $\begin{array}{r}(8.4) \\
(16.6) \\
(17.0)\end{array}$ & $\begin{array}{l}49.4 \\
55.6\end{array}$ & $\begin{array}{l}(11.8) \\
(13.3)\end{array}$ & $\begin{array}{l}-67.4 \pm \\
-51.0 \pm\end{array}$ & $\begin{array}{l}(-16.1) \\
(-12.2)\end{array}$ & $\begin{array}{r}0 \\
-33\end{array}$ & $\begin{array}{r}(0) \\
(-8)\end{array}$ & 58 \\
\hline 76 & $\begin{array}{l}\mathrm{NpO}_{2}^{2+}+\mathrm{H}_{2} \mathrm{Q}=\mathrm{NpO}_{2}^{+}+\mathrm{H}^{+}+\mathrm{HQ} \\
\mathrm{NpO}_{2}^{2+}+\mathrm{H}_{2} \mathrm{Q}=[*]^{2+}\end{array}$ & $\begin{array}{l}\mathrm{Net}^{\mathrm{h}} \\
1-0\end{array}$ & 1 & $\begin{array}{l}16.7 \\
48.1\end{array}$ & $\begin{array}{r}(4.0) \\
(11.5)\end{array}$ & 34.3 & $(8.2)$ & $-46.9 \pm 4.6$ & $(-11.2)$ & 75 & (18) & 145 \\
\hline 77 & $\begin{array}{l}\mathrm{Pu}^{4+}+\mathrm{H}_{2} \mathrm{Q}=\mathrm{Pu}^{3+}+\mathrm{H}^{+}+\mathrm{HQ} \cdot \\
\mathrm{Pu}^{4+}+\mathrm{H}_{2} \mathrm{Q}=[*]^{4+}\end{array}$ & $\begin{array}{l}\mathrm{Net}^{\mathrm{h}} \\
1-0^{\mathrm{h}}\end{array}$ & 1 & $\begin{array}{r}16.7 \\
44.4\end{array}$ & $\begin{array}{r}(4.0) \\
(10.6)\end{array}$ & 47.7 & (11.4) & $10.5 \pm 12.6$ & $(2.5)$ & -146 & $(-35)$ & 146 \\
\hline 78 & $\begin{array}{l}\mathrm{PuO}_{2}^{2+}+\mathrm{H}_{2} \mathrm{Q}=\mathrm{PuO}_{2}^{+}+\mathrm{H}^{+}+\mathrm{HQ} \\
\mathrm{PuO}_{2}^{2+}+\mathrm{H}_{2} \mathrm{Q}=\left[^{*}\right]^{1+}+\mathrm{H}^{+}\end{array}$ & $\begin{array}{l}\text { Neth } \\
1.0^{\mathrm{i}}\end{array}$ & & $\begin{array}{l}20.9 \\
54.8\end{array}$ & $\begin{array}{r}(5.0) \\
(13.1)\end{array}$ & 63.2 & $(15.1)$ & $34.7 \pm 1.3$ & $(8.3)$ & 159 & (38) & 146 \\
\hline 79 & $\begin{array}{l}6 \mathrm{Pu}^{3+}+\mathrm{XeO}_{3}+6 \mathrm{H}^{+}=6 \mathrm{Pu}^{4+}+\mathrm{Xe}+3 \mathrm{H}_{2} \mathrm{O} \\
\mathrm{Pu}^{3+}+\mathrm{XeO}_{3}=\left[{ }^{*}\right]^{3+}\end{array}$ & $\begin{array}{l}\text { Net } \\
1-0^{j}\end{array}$ & 2 & 84.1 & $(20.1)$ & 64.0 & $(15.3)$ & $-66.9 \pm 29.3$ & $(-16.0)$ & & & 147 \\
\hline
\end{tabular}

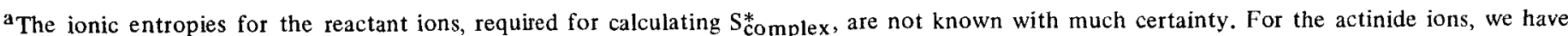
corrected the values given in Table 2.2 to unit ionic strength. For the various other reactants, we have chosen the values: $-31,-27,-25,-28,-31$, and $3 \mathrm{cal} / \mathrm{mol} \cdot \mathrm{deg}$ for $\mathrm{Fe}^{2+}, \mathrm{Cr}^{2+}, \mathrm{V}^{2+}, \mathrm{Mn}^{2+}, \mathrm{Co}^{2+}$, and $\mathrm{Eu}^{2+}$, respectively; $-70,-66,-62,-61,-71$, and $-40 \mathrm{cal} / \mathrm{mol}^{\circ} \mathrm{deg} \mathrm{for} \mathrm{Fe}^{3+}, \mathrm{Cr}^{3+}, \mathrm{V}^{3+}, \mathrm{Ti}^{3+}, \mathrm{Co}^{3+}$, and $\mathrm{Tl}^{3+}$, respectively; and $13.5,39,44,34,45$, and $36 \mathrm{cal} / \mathrm{mol} \cdot \mathrm{deg}$ for $\mathrm{Cl}^{-}, \mathrm{BrO}_{3}^{-}, \mathrm{HCrO}_{4}^{-}, \mathrm{H}_{2} \mathrm{O}_{2}, \mathrm{HClO}_{2}$, and $\mathrm{N}_{2} \mathrm{H}_{5}^{+}$, respectively. These estimates are

(Table continues on following page.) 
Table 8.1 (Continued)

based on published values ${ }^{148}$ and the Powell-Latimer correlation ${ }^{45}$ and are corrected to unit jonic strength. The average uncertainty may be about 5 based

boriginal data were recalculated for the table.

${ }^{c}$ Values are estimated from those for the reverse reaction.

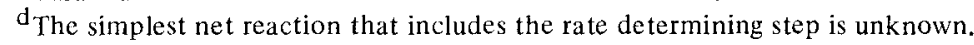

${ }^{\mathrm{e}}$ Complicated; see original reference.

$f_{\mathrm{A} \text { small }}\left[\mathrm{H}^{+}\right]$dependence has been assumed to be a medium effect given by Harned's Rule.

There is good evidence that this is a two-electron reaction.

$\mathrm{h}_{\mathrm{H}_{2}} \mathrm{Q}$ stands for hydroquinone.

Pattern is $2-1$ for overall reaction.

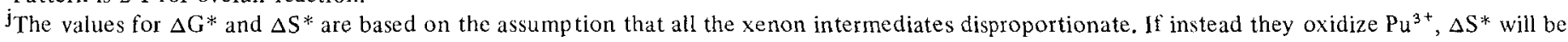
about $15 \mathrm{~J} / \mathrm{mol} \cdot \mathrm{K}$ more negative and $\Delta \mathrm{G}^{*}$ will be about $4.4 \mathrm{~kJ} / \mathrm{mol}$ greater than the tabulated values. 


\section{EMPIRICAL CORRELATIONS}

Many factors influence the rates of oxidation--reduction reactions; some are properties of the individual reactants (such as ionic charge, size, and the availability of bridging groups and appropriate orbitals), and some may be properties of the overall rate-determining reaction (such as $\Delta H$ and $\Delta z^{2}$ ). It is often difficult, however, to identify the appropriate overall reaction. Since the actual rate-determining step is usually unknown, the best we can do is take the simplest net reaction in terms of reasonably well-characterized reactants and products which includes the rate-determining step. The most elusive factors are those peculiar to particular reactant pairs.

Since rather large amounts of data on actinide oxidation-reduction reactions are now available, it is worthwhile to examine the data empirically to see if we can identify some general factors that influence the activation parameters and hence the reaction rates.

\section{HYDROGEN-ION DEPENDENCES}

For most of the reactions studied, the number of hydrogen ions gained or released in the net activation process lies between zero and the total number gained or released in the corresponding net process. This is consistent with the idea that the composition of the activated complex will be somewhere between the compositions of the reactants and of the products. Important exceptions to this generalization are the cases in which a hydrogen ion is lost in the net activation process but is not involved in the overall 
process. This can be viewed as a tendency for an activated complex to hydrolyze and thus reduce an otherwise high charge.

We can examine the concept of hydrolysis of activated complexes further by considering reactions involving two different net activation processes that differ by one hydrogen ion. For example, the rate law for the reduction of $\mathrm{Np}$ (IV) by $\mathrm{Cr}(\mathrm{II})$ is

$$
\frac{-\mathrm{d}[\mathrm{Np}(\mathrm{IV})]}{\mathrm{dt}}=\left[\mathrm{Np}^{4+}\right]\left[\mathrm{Cr}^{2+}\right]\left(\mathrm{k}_{1}\left[\mathrm{H}^{+}\right]^{-1}+\mathrm{k}_{2}\left[\mathrm{H}^{+}\right]^{-2}\right)
$$

and the two net activation processes are

$$
\mathrm{Np}^{4+}+\mathrm{Cr}^{2+}+\mathrm{H}_{2} \mathrm{O}=\left[^{*}\right]^{5+}+\mathrm{H}^{+}
$$

and

$$
\mathrm{Np}^{4+}+\mathrm{Cr}^{2+}+\mathrm{H}_{2} \mathrm{O}=\left[{ }^{*}\right]^{4+}+2 \mathrm{H}^{+}
$$

If the first process is subtracted from the second, we have, in a purely formal way, the hydrolysis of the first activated complex. Fourteen pairs ${ }^{\dagger}$ of activation processes which can be treated this way are found in Table 8.1. The results are shown in Table 9.1. We see that, even though different charges and compositions are involved, the $\Delta H^{*}$ and $\Delta S^{*}$ values for all but one of these formal processes are quite similar. The weighted average values and standard deviations (excluding process 11) are $20.2 \pm 0.09 \mathrm{~kJ} / \mathrm{mol}$ and $79 \pm 9 \mathrm{~J} / \mathrm{mol} \cdot \mathrm{K}$ for $\Delta \mathrm{H}^{*}$ and $\Delta \mathrm{S}^{*}$, respectively. These values are similar to those for highly charged actinide ions; for example, for $\mathrm{Pu}^{4+}+\mathrm{H}_{2} \mathrm{O}=$ $\mathrm{PuOH}^{3+}+\mathrm{H}^{+}, \Delta \mathrm{H}$ is $30.5 \pm 2 \mathrm{~kJ} / \mathrm{mol}$ and $\Delta \mathrm{S}$ is $79 \pm 9 \mathrm{~J} / \mathrm{mol} \cdot \mathrm{K}^{149}$ If the data are correct, the discordant value for the U(IV)-T1(III) reaction (process 11) suggests that the two activated complexes have quite different structures.

It has recently been suggested ${ }^{150}$ that reactions with nonintegral hydrogen-ion dependences, such as the $\mathrm{Np}$ (IV)-Cr(II) reaction and the others discussed in this section, actually have only one activated complex and one $\Delta \mathrm{H}^{*}$ but that $\Delta \mathrm{S}^{*}$ is a function of $\left[\mathrm{H}^{+}\right]$. Since this suggestion is contrary to the conventional interpretation given here, the available data were examined to see whether they are consistent with a single $\Delta \mathrm{H}^{*}$ value for each reaction independent of temperature. According to this hypothesis, the hydrogen-ion and temperature dependences should be given by the equation

$$
\mathrm{k}_{\mathrm{obs}}=\frac{\mathrm{k}_{\mathrm{B}} \mathrm{T}}{\mathrm{h}} \exp \left(\frac{\Delta \mathrm{S}^{*}}{\mathrm{R}}\right) \exp \left(-\frac{\Delta \mathrm{H}^{*}}{\mathrm{RT}}\right)\left[\mathrm{H}^{+}\right]^{\left(\mathrm{n}_{\mathrm{H}}+\mathrm{a}\left[\mathrm{H}^{+}\right]\right)}
$$

$\dagger$ The data for the $\mathrm{V}(\mathrm{III})-\mathrm{Np}(\mathrm{VI})$ reaction were not included, because they give the improbable value of $-255 \pm 84 \mathrm{~J} / \mathrm{mol} \cdot \mathrm{K}$ for $\Delta \mathrm{S}^{*}$ of hydrolysis. The original hydrogen-ion and temperature dependence have been recalculated under the assumption that activity effects are important (see Chap. 2, Sec. 2-4). Since this interpretation fits the data nearly as well as the assumption of parallel paths, it seems likely that only one activated complex is involved. 
Table 9.1

HYDROLYSIS OF ACTIVATED COMPLEXES

\begin{tabular}{|c|c|c|c|c|c|}
\hline & Process & $\begin{array}{c}\Delta \mathrm{G}^{*}, \\
\mathrm{~kJ} / \mathrm{mol} \\
(\mathrm{kcal} / \mathrm{mol})\end{array}$ & $\begin{array}{c}\Delta \mathrm{H}^{*}, \\
\mathrm{~kJ} / \mathrm{mol} \\
(\mathrm{kcal} / \mathrm{mol})\end{array}$ & $\begin{array}{c}\Delta S^{*} \\
\mathrm{~J} / \mathrm{mol} \cdot \mathrm{K} \\
(\mathrm{cal} / \mathrm{mol} \cdot \mathrm{deg})\end{array}$ & RMS ratio $\dagger$ \\
\hline 1 & {$\left[\mathrm{Fe} \cdot \mathrm{PuO}_{2}^{*}\right]^{4+}+\mathrm{H}_{2} \mathrm{O}=\left[{ }^{*}\right]^{3+}+\mathrm{H}^{+}$} & $0.4(0.1)$ & $21(5.0)$ & $71(17 \pm 2)$ & 2.15 \\
\hline 2 & {$\left[\mathrm{Co} \cdot \mathrm{NpO}_{2}^{*}\right]^{4+}+\mathrm{H}_{2} \mathrm{O}=\left[{ }^{*}\right]^{3+}+\mathrm{H}^{+}$} & $5.4(1.3)$ & $32(7.7)$ & $90(21.5 \pm 9)$ & 1.12 \\
\hline 3 & {$\left[\mathrm{~V} \cdot \mathrm{OH} \cdot \mathrm{UO}_{2}^{*}\right]^{4+}\left(+\mathrm{H}_{2} \mathrm{O}\right)=\left[{ }^{*}\right]^{3+}+\mathrm{H}^{+}$} & $7.1(1.7)$ & $18(4.4)$ & $38(9+2)$ & 2.02 \\
\hline 4 & {$\left[\mathrm{~Np} \cdot(\mathrm{OH})_{2} \cdot \mathrm{NpO}_{2}^{*}\right]^{4+}\left(+\mathrm{H}_{2} \mathrm{O}\right)=\left[{ }^{*}\right]^{3+}+\mathrm{H}^{+}$} & $2.7(0.65)$ & $29(6.9)$ & $171(41 \pm 17)$ & 0.95 \\
\hline 5 & {$\left[\mathrm{Cr} \cdot \mathrm{NpO}_{2} \cdot \mathrm{H}^{*}\right]^{4+}=[*]^{3+}+\mathrm{H}^{+}$} & $10.0(2.4)$ & $24(5.7)$ & $46(11 \pm 13)$ & 1.05 \\
\hline 6 & {$\left[\mathrm{Cr} \cdot \mathrm{OH} \cdot \mathrm{Np}^{*}\right]^{5+}\left(+\mathrm{H}_{2} \mathrm{O}\right)=\left[{ }^{*}\right]^{4+}+\mathrm{H}^{+}$} & $4.2(1.0)$ & $18(4.4)$ & $46(11 \pm 4)$ & 1.23 \\
\hline 7 & {$\left[\mathrm{U} \cdot \mathrm{OH} \cdot \mathrm{PuO}_{2}^{*}\right]^{5+}\left(+\mathrm{H}_{2} \mathrm{O}\right)=\left[{ }^{*}\right]^{4+}+\mathrm{H}^{+}$} & $-2.5(-0.6)$ & $15(3.7)$ & $59(14 \pm 2)$ & 2.41 \\
\hline 8 & {$\left[\mathrm{Pu} \cdot \mathrm{NpO}_{2}^{*}\right]^{5+}+\mathrm{H}_{2} \mathrm{O}=\left[{ }^{*}\right]^{4} \mathrm{t}+\mathrm{H}^{+}$} & $5.9(1.4)$ & $22(5.3)$ & $109(26 \pm 1)$ & 1.23 \\
\hline 9 & {$\left[\mathrm{~Np} \cdot \mathrm{UO}_{2}^{*}\right]^{5+}+\mathrm{H}_{2} \mathrm{O}=\left[^{*}\right]^{4+}+\mathrm{H}^{+}$} & $8.4(2.0)$ & $36(8.7)$ & $96(23 \pm 7)$ & 0.95 \\
\hline 10 & {$\left[\mathrm{~V} \cdot \mathrm{Pu} \cdot \mathrm{OH}^{*}\right]^{6+}\left(+\mathrm{H}_{2} \mathrm{O}\right)=\left[{ }^{*}\right]^{5+}+\mathrm{H}^{+}$} & $-1.7(-0.4)$ & $18(4.4)$ & $67(16 \pm 4)$ & 1.09 \\
\hline 11 & {$\left[\mathrm{Tl} \cdot \mathrm{U} \cdot \mathrm{OH}^{*}\right]^{6+}\left(+\mathrm{H}_{2} \mathrm{O}\right)=\left[{ }^{*}\right]^{5+}+\mathrm{H}^{+}$} & $0(0)$ & $-18(-4.2)$ & $-59(-14 \pm 8)$ & 1.14 \\
\hline 12 & {$\left[\mathrm{Fe} \cdot \mathrm{U} \cdot \mathrm{OH}^{*}\right]^{6+}\left(+\mathrm{H}_{2} \mathrm{O}\right)=\left[{ }^{*}\right]^{5+}+\mathrm{H}^{+}$} & $-4.0(-1)$ & $26(6.1)$ & $100(24 \pm 10)$ & 0.95 \\
\hline $13 \ddagger$ & {$\left[\mathrm{Np}(\mathrm{VII}) \cdot \mathrm{Hg}_{2} \cdot \mathrm{H}^{*}\right]^{\mathrm{n}+3}=\left[^{*}\right]^{\mathrm{n}+2}+\mathrm{H}^{+}$} & $-1.7(-0.4)$ & $18(4.4)$ & $67(16 \pm 4)$ & 1.18 \\
\hline $14 \ddagger$ & {$\left[\mathrm{Np}(\mathrm{VII}) \cdot \mathrm{HCO}_{2} \mathrm{H}^{*}\right]^{\mathrm{n}}=\left[{ }^{*}\right]^{\mathrm{n}-1}+\mathrm{H}^{+}$} & $5.0(1.2)$ & $17(4.1)$ & $42(10 \pm 2)$ & 1.56 \\
\hline
\end{tabular}

$\dagger$ The root-mean-square deviation found by Eq. 9.4 over the same quantity based on two activated complexes.

$\neq n$ is the unknown charge on $\mathrm{Np}(\mathrm{VII})$ in acid solution. 
where $\mathrm{n}_{\mathrm{H}_{1}}$ is the empirical $\left[\mathrm{H}^{+}\right]$dependence and $\mathrm{a}$ is an allowance for small curvature in graphs of $\log \mathrm{k}_{\mathrm{Obs}}$ vs. $\log \left[\mathrm{H}^{+}\right]$. The data for the 14 reactions in Table 9.1 were fitted to this equation by a least-squares procedure, and the root-mean-square deviations were compared with those obtained by the conventional equations. The ratios of these deviations are given in the last column of the table. For three of the reactions, Eq. 9.4 fits the data better than the conventional one; for four of the reactions, the equation is only a little poorer; and, for the remaining seven reactions, the fit is significantly poorer. These calculations, together with the reasonably consistent values for $\Delta H^{*}$ and $\Delta \mathrm{S}^{*}$ for hydrolysis shown in the table, support the usual concept of distinct activated complexes formed with definite numbers of hydrogen ions and indicate that Eq. 9.4 is not generally satisfactory.

\section{9-2}

\section{ENTROPIES OF ACTIVATION}

The entropy of activation depends on the structural changes that occur in the reactant ions and solvation shells when the activated complex is formed. Some of these changes depend on the particular reaction, but some more general effects can be expected also. For example, $\Delta \mathrm{S}^{*}$ is expected to depend on $\Delta \mathrm{n}$, the change in the number of nonsolvent molecules (or ions) in the activation process. This is related to the fact that $\Delta \mathrm{n}$ determines the purely mixing part of the entropy change. ${ }^{151}$ Changes in the symmetry numbers should also affect $\Delta S^{*}{ }^{152}$ We are forced to ignore this factor because the details of the structures of the activated complexes are unknown. The entropy of activation is also expected to have an electrostatic component that depends on $\Delta \mathrm{z}^{2}$, the change in the sum of the squares of the ionic charges in the activation process. ${ }^{153}$ Since, in addition, rapid reactions involve the crossing of lower free-energy barriers and presumably involve less distortion during activation, $\Delta \mathrm{G}^{*}$ might also show an influence. A correlation between $\Delta \mathrm{S}^{*}$ and $\Delta \mathrm{H}^{*}$, described as a compensatory effect, has been noted previously. ${ }^{154,155}$ Such an effect would also imply a correlation between $\Delta S^{*}$, and $\Delta \mathrm{G}^{*}$ since $\Delta \mathrm{H}^{*}=\Delta \mathrm{G}^{*}+\mathrm{T} \Delta \mathrm{S}^{*}$.

Table 8.1 lists $96 \Delta S^{*}$ values that can be used; these range from -201 to $+218 \mathrm{~J} / \mathrm{mol} \cdot \mathrm{K}$, with an average of -31.66 and a root-mean-square deviation of $97 \mathrm{~J} / \mathrm{mol} \cdot \mathrm{K}$. If the factors discussed have an influence on $\Delta \mathrm{S}^{*}$, the expression

$$
\Delta \mathrm{S}^{*}=\mathrm{a}+\mathrm{b} \Delta \mathrm{n}+\mathrm{c} \Delta \mathrm{z}^{2}+\mathrm{d} \Delta \mathrm{G}^{*}
$$

can be fit to the data; the coefficients will have relatively small uncertainties; and the difference between the observed and calculated values will be smaller than the deviation from the average value. A standard least-squares procedure was used to find the best values for the four parameters and their standard deviations. These are listed in Table 9.2, along with the root-mean-square deviation between observed and 
Table 9.2

CORRELATION OF ENTROPIES OF ACTIVATION $+\neq$

$\left(\Delta S^{*}=a+b \Delta n+c \Delta z^{2}+d \Delta G^{*}\right)$

\begin{tabular}{cccccc}
\hline $\begin{array}{c}\text { No. of } \\
\text { data }\end{array}$ & \multicolumn{1}{c}{$\mathbf{a}, \mathbf{m o l} \cdot \mathbf{K}$} & \multicolumn{1}{c}{$\mathbf{b}, \mathbf{J} / \mathbf{m o l} \cdot \mathbf{K}$} & $\begin{array}{c}\mathbf{c}, \mathbf{m o l} \cdot \mathbf{K} \\
\mathbf{J}\end{array}$ & $\begin{array}{c}\mathbf{d}, \mathbf{J} \cdot \mathbf{K} \\
\mathbf{J}\end{array}$ & $\begin{array}{c}\text { RMS dev., } \\
\mathbf{J} / \mathbf{m o l} \cdot \mathbf{K}\end{array}$ \\
\hline 96 & $-26.6 \pm 35.2$ & $27.9 \pm 5.4$ & $-6.2 \pm 0.9$ & $0.62 \pm 0.50$ & 66 \\
96 & $16.4 \pm 8.4$ & $28.2 \pm 5.4$ & $-6.3 \pm 0.9$ & 0 (fixed) & 67 \\
96 & $-31.7 \pm 9.9$ & 0 (fixed) & 0 (fixed) & 0 (fixed) & 97 \\
$79 \boldsymbol{9}$ & $-23.6 \pm 31.4$ & $37.3 \pm 4.9$ & $-7.8 \pm 0.8$ & $0.92 \pm 0.44$ & 52 \\
79 & $40.2 \pm 8.3$ & $37.8 \pm 5.0$ & $-8.0 \pm 0.8$ & 0 (fixed) & 54 \\
79 & $-33.9 \pm 11.5$ & 0 (fixed) & 0 (fixed) & 0 (fixed) & 102 \\
\hline
\end{tabular}

†All pertinent data from Table 8.1.

+Uncertainties are standard deviations.

$\S$ Root-mean-square deviation between observed and calculated values.

१ Data for processes involving nonmetalic and anionic substances are omitted.

calculated values. We see that, since the coefficient for $\Delta G^{*}$ is less than twice its standard deviation, it is not statistically significant. Repeating the calculation with fixed at zero gives essentially the same deviation.

Most of the data showing large deviations involve reactions of nonmetallic or anionic substances, such as $\mathrm{BrO}_{3}^{-}$or $\mathrm{H}_{2} \mathrm{O}_{2}$. The 17 processes in this class were excluded, and the calculations were repeated. These results, also given in Table 9.2, show that the values for the various parameters are not changed significantly but the root-mean-square deviations are greatly reduced.

These calculations show that both $\Delta \mathrm{n}$ and $\Delta \mathrm{z}^{2}$ are important factors in determining $\Delta S^{*}$ but that $\Delta \mathrm{G}^{*}$ probably is not. No correlation with $\Delta \mathrm{G}^{*}$ alone was found. We should note, however, that the smallest root-mean-square deviation in the table $(52 \mathrm{~J} / \mathrm{mol} \cdot \mathrm{K})$ is very much larger than the usual experimental uncertainty in $\Delta \mathrm{S}^{*}$; this indicates that other very important factors remain to be identified.

The effect of $\Delta n$, as indicated by the size of parameter $b$, seems quite reasonable since the use of a simple lattice model gives $34 \mathrm{~J} / \mathrm{mol} \cdot \mathrm{K}$ for the coefficient for $\Delta \mathrm{n} .{ }^{151}$ On the other hand, the effect of $\Delta \mathrm{z}^{2}$, indicated by $\mathrm{c}$, is smaller than might be expected but does have the expected sign. The electrostatic contribution to $\Delta S^{*}$ at infinite dilution in water at $25^{\circ} \mathrm{C}$ is given by $-42 \mathrm{z}_{\mathrm{a}} \mathrm{z}_{\mathrm{b}}$ for an approach of ions charged $z_{a}$ and $z_{b}$ to a distance of $0.2 n m^{153}$ This corresponds to $-4.2 \Delta z^{2} / \mathrm{r}^{*}$, where $\mathrm{r}^{*}$ is the effective distance of approach in nanometers in the formation of the activated complex. The effect becomes smaller at larger ionic strengths, and, using parameters from Chap. 7 , we estimate $\left[\left(-4.2 / \mathrm{r}^{*}\right)+2.5\right] \Delta \mathrm{z}^{2}$ for unit ionic strength. Thus a coefficient for $\Delta \mathrm{z}^{2}$ of $-8 \mathrm{~J} / \mathrm{mol} \cdot \mathrm{K}$ implies that $\mathrm{r}^{*}$ is $0.4 \mathrm{~nm}$, which seems to be at least $50 \%$ too high. 
9-3

\section{ENTROPIES OF THE ACTIVATED COMPLEXES}

A somewhat different approach to activation entropies involves the calculation of the formal ionic entropies of the activated complexes themselves. The entropies of ordinary aqueous ions have been shown to depend strongly on ionic charge and to a lesser extent on radius and mass. ${ }^{45} \mathrm{~A}$ similar but much rougher correlation has been noted for activated complexes. ${ }^{156}$ relation

The formal ionic entropy of an activated complex, $\mathrm{S}_{\text {complex }}^{*}$, is defined by the

$$
\mathrm{S}_{\text {complex }}^{*}=\Delta \mathrm{S}^{*}+\sum \mathrm{S}_{\mathrm{reactants}}^{0}-\sum \mathrm{S}_{\mathrm{other} \text { products }}^{0}
$$

This definition can be ambiguous because the number of moles of water involved in a net activation process is not known with certainty. For example, the net activation process for the second term in the rate law for the $\mathrm{Pu(IV)}-\mathrm{V}$ (III) reaction (see Chap. 3, Sec. 3-1) can be written as either

$$
\mathrm{Pu}^{4+}+\mathrm{V}^{3+}+\mathrm{H}_{2} \mathrm{O}=\left[\mathrm{Pu} \cdot \mathrm{O} \cdot \mathrm{V}^{5+}\right]^{*}+2 \mathrm{H}^{+}
$$

or

$$
\mathrm{Pu}^{4+}+\mathrm{V}^{3+}+2 \mathrm{H}_{2} \mathrm{O}=\left[\mathrm{Pu} \cdot(\mathrm{OH})_{2} \cdot \mathrm{V}^{5+}\right]^{*}+2 \mathrm{H}^{+}
$$

In this example the value for $\mathrm{S}_{\text {complex }}^{*}$ defined in terms of the second process will be about $70 \mathrm{~J} / \mathrm{mol} \cdot \mathrm{K}$ more positive than the value defined in terms of the first process.

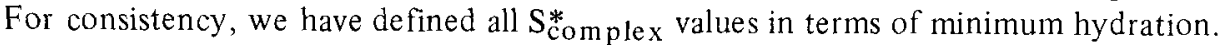

The values for $S_{\text {complex }}^{*}$ defined this way are plotted vs. the charge on the activated complex in Fig. 9.1. The data show considerable scatter, but a definite trend is quite obvious. If $\mathrm{S}_{\text {complex }}^{*}$ is assumed to be linear in the charge on the activated complex, the scatter (measured by the root-mean-square deviation) is about $15 \%$ greater than for the $\Delta S^{*}$ values according to Eq. 9.5 .

\section{4}

\section{HEATS OF ACTIVATION}

A graph of the available values for $\Delta H^{*}$ vs. $\Delta H$ showed that most of the data fall in a band with a small positive slope. The $\Delta \mathrm{H}^{*}$ values for the net activation processes that do not involve hydrogen ions tended to be lower than average, however, and those for processes in which two hydrogen ions are released tended to be above average. This leads us to postulate an empirical correlation of the form 


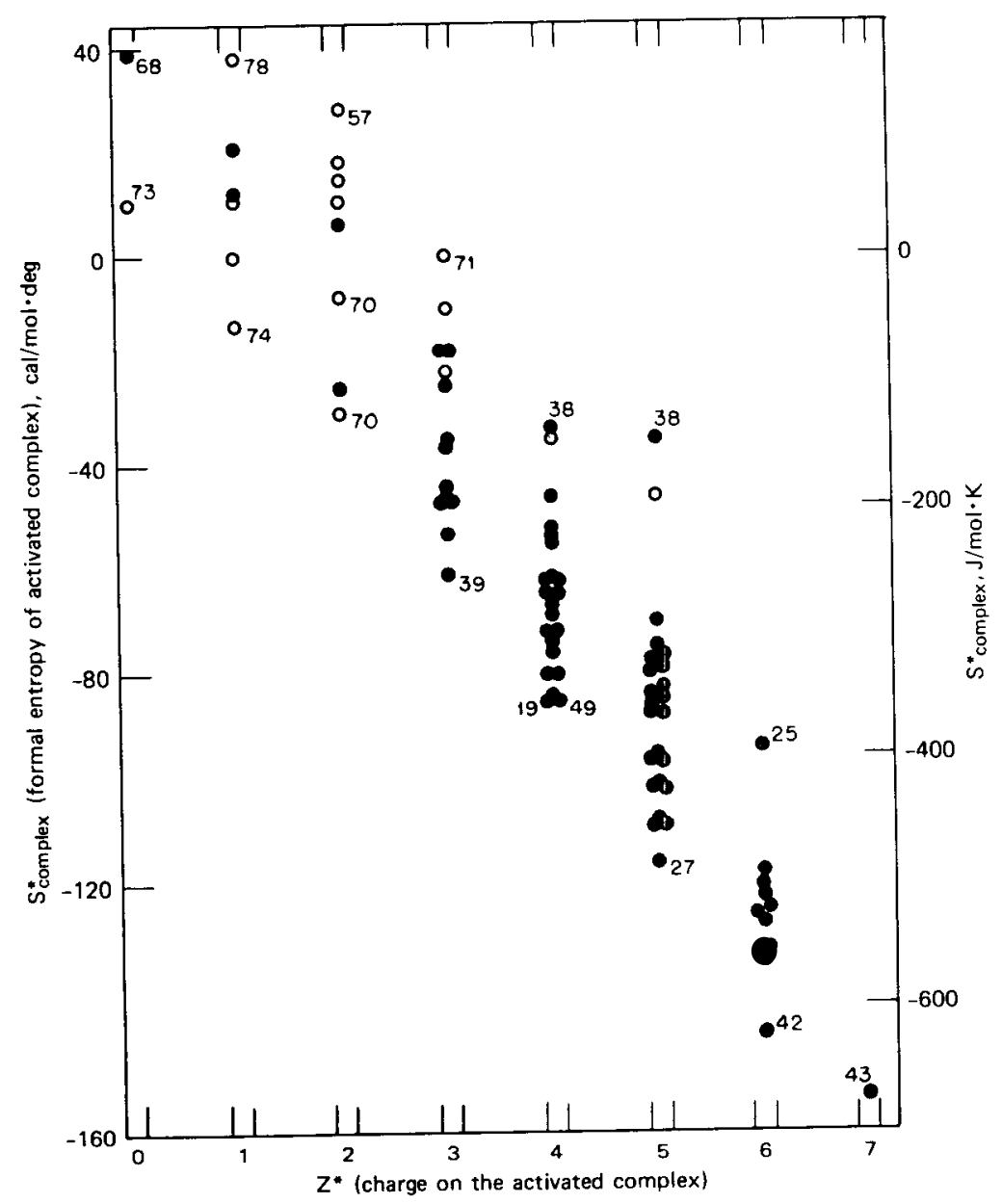

Fig. 9.1 Formal entropy vs. charge for the activated complexes. Reaction numbers are from Table 8.1. Open circles $(O)$ refer to reactions with nonmetallic or anionic reagents.

$$
\Delta \mathrm{H}^{*}=\mathrm{a}+\mathrm{b} \Delta \mathrm{H}+\mathrm{c}|\mathrm{h}|
$$

where $|\mathrm{h}|$ is the absolute value of the number of hydrogen ions gained in the net activation process. The data for the 71 pertinent processes in Table 8.1 were used to find the best values for the parameters. These values are $\mathrm{a}=41.4 \pm 6.2 \mathrm{~kJ} / \mathrm{mol}, \mathrm{b}=$ $0.16 \pm 0.05$, and $c=23.0 \pm 3.9 \mathrm{~kJ} / \mathrm{mol}$. The data scatter considerably, giving a root-mean-square deviation of $25 \mathrm{~kJ} / \mathrm{mol}$, which is much less than the $37.6 \mathrm{~kJ} / \mathrm{mol}$ for the $\Delta \mathrm{H}^{*}$ values themselves. As was the case for the $\Delta \mathrm{S}^{*}$ values, the processes involving nonmetallic and anionic substances show the most scatter. When these four processes 
were omitted, the root-mean-square deviation was reduced to $19 \mathrm{~kJ} / \mathrm{mol}$, $\dagger$ but the values for $a, b$, and $c$ were changed very little. Thus we conclude that $\Delta H^{*}$ correlates with both $\Delta H$ and $|h|$.

To illustrate this correlation and to show the range of values involved, we plotted the quantity $\Delta \mathrm{H}^{*}-23.9|\mathrm{~h}|$ vs. $\Delta \mathrm{H}$ in Fig. 9.2.

The observed dependence on $|\mathrm{h}|$ implies that, on the average, about $24 \mathrm{~kJ} / \mathrm{mol}$ are contributed to $\Delta \mathrm{H}^{*}$ for each hydrogen ion. This may be the average value required for the formation of a reactive intermediate by either loss or gain of a hydrogen ion. This is consistent with the results in Table 9.1 , where it was shown that $\Delta \mathbf{H}^{*}$ averages about $20 \mathrm{~kJ} / \mathrm{mol}$ for the loss of a hydrogen ion from one activated complex to form another.

\section{9-5}

\section{FREE ENERGIES OF ACTIVATION}

Since $\Delta H^{*}$ correlates with $\Delta H$ and $|\mathrm{h}|$ and $\Delta \mathrm{S}^{*}$ correlates with $\Delta \mathrm{n}$ and $\Delta \mathrm{z}^{2}, \Delta \mathrm{G}^{*}$ is expected to correlate with these quantities also. The function

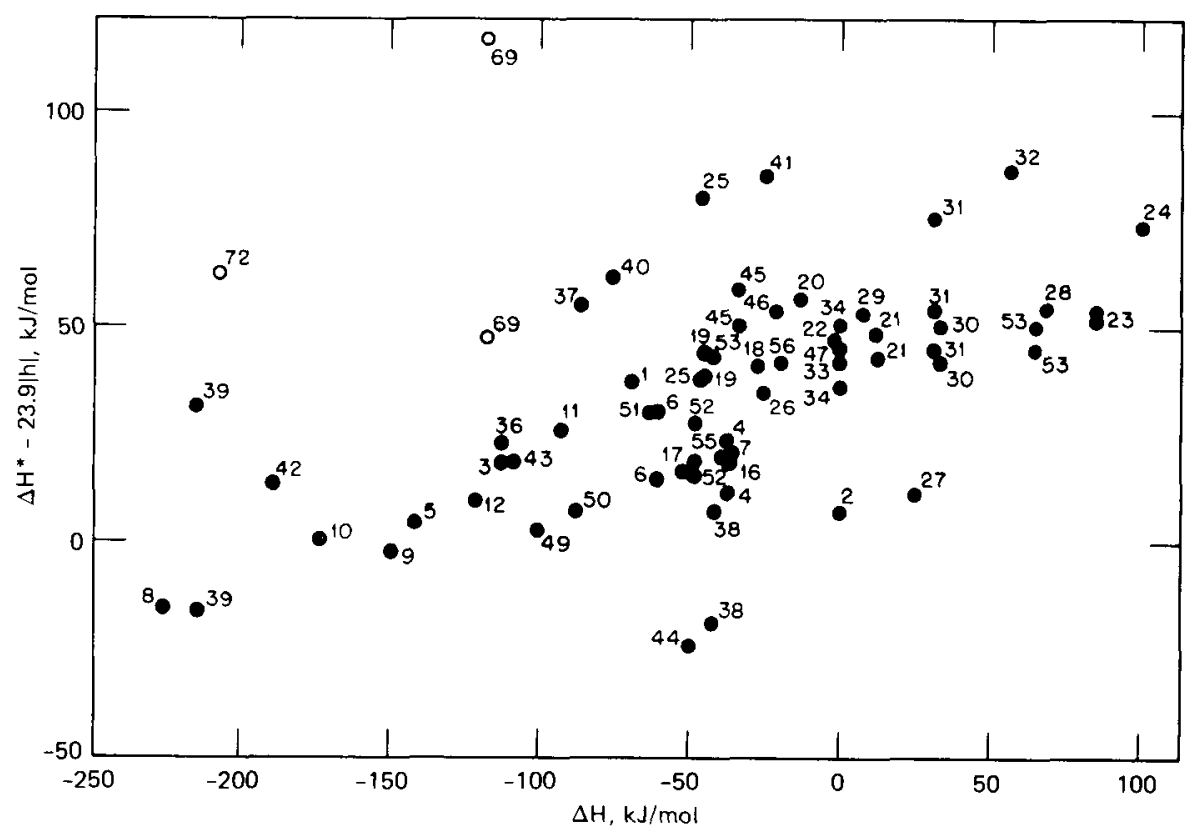

Fig. 9.2 Heat of activation vs. heat of reaction. Reaction numbers are from Table 8.1. Open circles (o) refer to reactions with nonmetallic agents.

$\dagger$ This can be reduced to $17 \mathrm{~kJ} / \mathrm{mol}$ if a term for $\Delta \mathrm{z}^{2}$ is included. 


$$
\Delta \mathrm{G}^{*}=\mathrm{a}+\mathrm{b} \Delta \mathrm{H}+\mathrm{c}|\mathrm{h}|+\mathrm{d} \Delta \mathrm{n}+\mathrm{e} \Delta \mathrm{z}^{2}
$$

was tested as before by using the 71 net activation processes from Table 8.1 for which the necessary data are available. The results of the calculations are summarized in Table 9.3. The first calculation shows that $\Delta G^{*}$ apparently does not depend on $\Delta z^{2}$ even though $\Delta S^{*}$ does. The calculation was repeated with $e=0$ with little effect on any of the remaining parameters or on the deviations between observed and calculated values. The observed values of $\Delta G^{*}$ corrected for the effects of $|\mathrm{h}|$ and $\Delta \mathrm{n}$ are plotted vs. $\Delta \mathrm{H}$ in Fig. 9.3. The scatter shows that one or more important terms have yet to be recognized. However, $82 \%$ of the points have deviations less than $11.4 \mathrm{~kJ} / \mathrm{mol}$, which corresponds to a factor of 100 in actual rate.

If $\Delta \mathrm{G}$ is used instead of $\Delta H$ in Eq. 9.10 , calculations show that $\Delta \mathrm{G}^{*}$ correlates with $|\mathrm{h}|$ and $\Delta \mathrm{n}$ but with neither $\Delta \mathrm{G}$ nor $\Delta \mathrm{z}^{2}$. This is to be contrasted with the results for actinide-actinide reactions where good correlations were observed (Chap. 4).

The correlations discussed in this section are interesting in that they show the relative importance of the physical factors $|\mathrm{h}|, \Delta \mathrm{n}$, and $\Delta \mathrm{z}^{2}$. They are of very little predictive value, however, since they strongly support the old teaching that, in general, the rate of a reaction is not determined by its equilibrium.

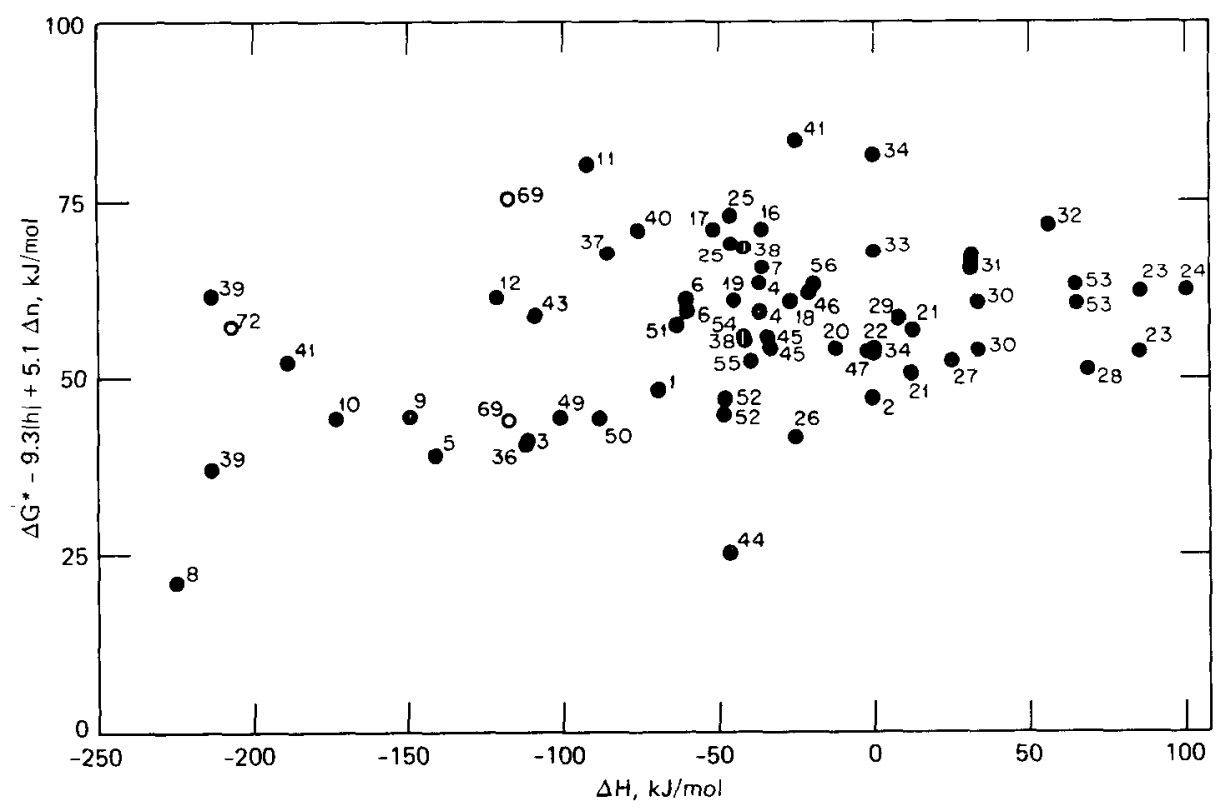

Fig. 9.3 Free energy of activation, corrected for $h /$ and $\Delta n$, vs. heat of reaction. Reaction numbers are from Table 8.1. Open circles $(0)$ refer to reactions with nonmetallic reagents. 
Table 9.3

CORRELATION OF FREE ENERGIES OF ACTIVATION $\uparrow \ddagger$

$\left(\Delta \mathrm{G}^{*}=\mathrm{a}+\mathrm{b} \Delta \mathrm{H}+\mathrm{c}|\mathrm{h}|+\mathrm{d} \Delta \mathrm{n}+\mathrm{e} \Delta \mathrm{z}^{2}\right)$

\begin{tabular}{|c|c|c|c|c|c|}
\hline$\stackrel{\mathrm{a},}{\mathrm{kJ} / \mathrm{mol}}$ & b & $\begin{array}{c}\mathrm{c}, \\
\mathrm{kJ} / \mathrm{mol}\end{array}$ & $\stackrel{\mathrm{d}}{\mathrm{kJ} / \mathrm{mol}}$ & $\begin{array}{c}\mathrm{e}, \\
\mathrm{kJ} / \mathrm{mol}\end{array}$ & $\begin{array}{c}\text { RMS dev., } \S \\
\mathrm{kJ} / \mathrm{mol}\end{array}$ \\
\hline $63 \pm 4$ & $0.065 \pm 0.025$ & $8.2 \pm 1.8$ & $6.8 \pm 1.8$ & $0.44 \pm 0.27$ & 10.6 \\
\hline $60 \pm 3$ & $0.057 \pm 0.024$ & $9.3 \pm 1.7$ & $5.1 \pm 1.5$ & 0 (fixed) & 10.9 \\
\hline $69 \pm 2$ & 0 (fixed) & 0 (fixed) & 0 (fixed) & 0 (fixed) & 14.2 \\
\hline
\end{tabular}

†Data from 71 activation processes.

$\ddagger$ Uncertainties are standard deviations.

$\S$ Root-mean-square deviation between observed and calculated values. 


\section{Datalog of}

The data on the oxidation-reduction reactions of uranium, neptunium, plutonium, and americium which were available in the fall of 1973 are listed in Tables 10.1 to 10.24 in this chapter. Results of the older work were adapted from the compilations by Magnusson and coworkers ${ }^{157}$ and by Connick. ${ }^{158}$ Although some of these results are only qualitative, they are included because they provide good bases for further work.

Semiquantitative results are given in terms of half-lives under the specified conditions of concentration and temperature. Where possible, typical values for the rate constants are given; $\mathrm{k}$ is used for first-order rate constants, $\mathrm{k}^{\prime}$, for second-order rate constants written in terms of uncomplexed or unhydrolyzed species, and $\mathrm{k}^{\prime \prime}$, for second-order rate constants written in terms of the stoichiometric concentrations. The rate constants apply to the rate of change of concentration of the actinide ion or, if both reactants are actinides, to the actinide ion being oxidized; for example, in the reaction $2 \mathrm{Pu}(\mathrm{IV})+\mathrm{U}(\mathrm{IV})=2 \mathrm{Pu}(\mathrm{III})+\mathrm{U}(\mathrm{VI})$

$$
-\frac{\mathrm{d}[\mathrm{U}(\mathrm{IV})]}{\mathrm{dt}}=-\frac{1}{2} \frac{\mathrm{d}[\mathrm{Pu}(\mathrm{IV})]}{\mathrm{dt}}=\mathrm{k}^{\prime \prime}[\mathrm{Pu}(\mathrm{IV})][\mathrm{U}(\mathrm{IV})]=\mathrm{k}^{\prime}\left[\mathrm{Pu}^{4+}\right]\left[\mathrm{U}^{4+}\right]
$$

The available temperature dependences are given either by $\mathrm{E}_{\mathrm{a}}$ in terms of the Arrhenius equation or by $\Delta \mathrm{H}^{*}$ in terms of the Eyring equation (Eq. 3.1). These quantities are related by $\Delta \mathrm{H}^{*}=\mathrm{E}_{\mathrm{a}}-\mathrm{RT}$. The values of these quantities are given both in kilojoules per mole and in kilocalories per mole, the latter in parentheses.

The significance of the uncertainties given by the various authors is not always clear. Usually they appear to be estimates of precision rather than of accuracy and can be taken to approximate one standard deviation. 
Table 10.1

OXIDATION OF URANIUM(III) TO URANIUM(IV)

\begin{tabular}{|c|c|c|c|c|c|}
\hline Agent & $\begin{array}{c}\text { Typical } \\
\text { concentration, } M\end{array}$ & Solution & ${ }^{\circ} \mathrm{C}$ & Results & Ref. \\
\hline $\mathrm{ClO}_{4}^{-}$ & & $\begin{array}{l}0.5 \mathrm{M} \mathrm{HClO}_{4} \\
6.0 \mathrm{M} \mathrm{HClO}_{4}\end{array}$ & 22 & $\begin{array}{l}\mathrm{k}=1.8 \times 10^{-5} \mathrm{sec}^{-1} \\
\mathrm{E}_{\mathrm{d}}=92(22) \\
\mathrm{k}=8.7 \times 10^{-4} \mathrm{sec}^{-1}\end{array}$ & 159 \\
\hline $\mathrm{Co}\left(\mathrm{NH}_{3}\right)_{5} \mathrm{Cl}^{2+}$ & $3 \times 10^{-4}$ & $0.2 \mathrm{M}(\mathrm{H}, \mathrm{Li}) \mathrm{ClO}_{4}$ & 25 & $\mathrm{k}^{\prime \prime}=(3.24 \pm 0.05) \times 10^{4}\left[\mathrm{H}^{+}\right]^{0} M^{-1} \mathrm{sec}^{-1}$ & 18 \\
\hline $\mathrm{Co}\left(\mathrm{NH}_{3}\right)_{5} \mathrm{Br}^{2+}$ & $10^{-3}$ & $0.2 \mathrm{M}(\mathrm{H}, \mathrm{Li}) \mathrm{ClO}_{4}$ & 25 & $\mathrm{k}^{\prime \prime}=(1.42 \pm 0.01) \times\left[0^{4}\left[\mathrm{H}^{+}\right]^{0} M^{-1} \sec ^{-1}\right.$ & 18 \\
\hline $\mathrm{Co}\left(\mathrm{NH}_{3}\right)_{5} \mathrm{~N}_{3}^{2+}$ & $5 \times 10^{-5}$ & $0.2 \mathrm{M}(\mathrm{H}, \mathrm{Li}) \mathrm{ClO}_{4}$ & 25 & $\mathrm{k}^{\prime \prime}=(1.08 \pm 0.08) \times 10^{6}\left[\mathrm{H}^{+}\right]^{0} M^{-1} \sec ^{-1}$ & 18 \\
\hline $\mathrm{Co}\left(\mathrm{NH}_{3}\right)_{5} \mathrm{~F}^{2+}$ & $1.2 \times 10^{-4}$ & $0.2 \mathrm{M}(\mathrm{H}, \mathrm{Li}) \mathrm{ClO}_{4}$ & 25 & $\mathrm{k}^{\prime \prime}=(5.4 \pm 0.13) \times 10^{5}\left[\mathrm{H}^{+}\right]^{0} \mathrm{M}^{-1} \mathrm{sec}^{-1}$ & 18 \\
\hline $\mathrm{Co}\left(\mathrm{NH}_{3}\right)_{5} \mathrm{OAc}^{2+}$ & $8 \times 10^{-4}$ & $0.2 \mathrm{M}(\mathrm{H}, \mathrm{Li}) \mathrm{ClO}_{4}$ & 25 & $\mathrm{k}^{\prime \prime}=(1.5 \pm 0.14) \times 10^{4}\left[\mathrm{H}^{+}\right]^{0} M^{-1} \mathrm{sec}^{-1}$ & 18 \\
\hline $\mathrm{Co}\left(\mathrm{NH}_{3}\right)_{5} \mathrm{CN}^{2+}$ & $1.2 \times 10^{-3}$ & $0.2 \mathrm{M}(\mathrm{H}, \mathrm{Li}) \mathrm{ClO}_{4}$ & 25 & $\mathrm{k}^{\prime \prime}=(3.45 \pm 0.22) \times 10^{3}\left[\mathrm{H}^{+}\right]^{0} M^{-1} \sec ^{-1}$ & 18 \\
\hline $\mathrm{Co}\left(\mathrm{NH}_{3}\right)_{5} \mathrm{NCS}^{2+}$ & $8 \times 10^{-4}$ & $0.2 \mathrm{M}(\mathrm{H}, \mathrm{Li}) \mathrm{ClO}_{4}$ & 25 & $\mathrm{k}^{\prime \prime}=(18.2 \pm 0.6)\left[\mathrm{H}^{+}\right]^{0} M^{1} \mathrm{sec}^{-1}$ & 18 \\
\hline $\operatorname{cis}-\mathrm{Co}(\mathrm{en})_{2} \mathrm{Cl}_{2}^{2+}$ & $4 \times 10^{-4}$ & $0.2 \mathrm{M}(\mathrm{H}, \mathrm{Li}) \mathrm{ClO}_{4}$ & 25 & $\mathrm{k}^{\prime \prime}=(2.15 \pm 0.05) \times 10^{4}\left[\mathrm{H}^{+}\right]^{0} M^{-1} \mathrm{sec}^{-1}$ & 18 \\
\hline trans-Co(en $)_{2} \mathrm{Cl}_{2}^{2+}$ & $1 \times 10^{-4}$ & $0.2 \mathrm{M}(\mathrm{H}, \mathrm{Li}) \mathrm{ClO}_{4}$ & 25 & $\mathrm{k}^{\prime \prime}=(2.15 \pm 0.08) \times 10^{5}\left[\mathrm{H}^{+}\right]^{0} M^{-1} \sec ^{-1}$ & 18 \\
\hline cis-Co(en $)_{2}\left(\mathrm{H}_{2} \mathrm{O}\right) \mathrm{Cl}^{2+}$ & $4 \times 10^{-4}$ & $0.2 \mathrm{M}(\mathrm{H}, \mathrm{Li}) \mathrm{ClO}_{4}$ & 25 & $\mathrm{k}^{\prime \prime}=(1.94 \pm 0.06) \times 10^{4}\left[\mathrm{H}^{+}\right]^{-0.06} \mathrm{M}^{-1} \mathrm{sec}^{-1}$ & 18 \\
\hline trans-Co(en $)_{2}\left(\mathrm{H}_{2} \mathrm{O}\right) \mathrm{CN}^{2+}$ & $7 \times 10^{-4}$ & $0.2 \mathrm{M}_{(\mathrm{H}, \mathrm{Li}) \mathrm{ClO}_{4}}$ & 25 & $\mathrm{k}^{\prime \prime}=(\sim 8) \times 10^{4}\left[\mathrm{H}^{+}\right]^{0} M^{-1} \sec ^{-1}$ & 18 \\
\hline $\mathrm{Co}\left(\mathrm{NH}_{3}\right)_{6}^{3+}$ & $10^{-3}$ & $0.2 \mathrm{M}(\mathrm{H}, \mathrm{Li}) \mathrm{ClO}_{4}^{4}$ & 25 & $\begin{array}{l}\mathrm{k}^{\prime \prime}=(1.32 \pm 0.04)\left[\mathrm{H}^{+}\right]^{0} M^{-1} \mathrm{sec}^{-1} \\
\text { Catalyzed by halide ions }\end{array}$ & 18 \\
\hline $\mathrm{Co}(\mathrm{en})_{3}^{3+}$ & $10^{-3}$ & $0.2 \mathrm{M}(\mathrm{H}, \mathrm{Li}) \mathrm{ClO}_{4}$ & 25 & $\begin{array}{l}\mathrm{k}^{\prime \prime}=0.133\left[\mathrm{H}^{+}\right]^{0} M^{1} \sec ^{-1} \\
\text { Catalyzed by halide ions }\end{array}$ & 18 \\
\hline $\mathrm{Co}\left(\mathrm{NH}_{3}\right)_{5}\left(\mathrm{H}_{2} \mathrm{O}\right)^{3+}$ & $1.3 \times 10^{-3}$ & $\begin{array}{l}0.1 \mathrm{M} \mathrm{HClO}_{4}- \\
0.1 \mathrm{M} \mathrm{LiClO}_{4}\end{array}$ & 25 & $\begin{array}{l}\mathrm{k}^{\prime \prime}=28.4 \pm 1.2 \mathrm{M}^{-1} \mathrm{sec}^{-1} \\
\text { Complicated }\left[\mathrm{H}^{+}\right] \text {dependence }\end{array}$ & 18 \\
\hline
\end{tabular}




\begin{tabular}{|c|c|c|c|c|c|}
\hline trans- & $9 \times 10^{-4}$ & $0.1 M \mathrm{LiClO}_{4}$ & 25 & $\mathrm{k}^{\prime \prime}=40.1 \pm 0.1 M^{-1} \mathrm{sec}^{-1}$ & 18 \\
\hline $\mathrm{Co}(\mathrm{en})_{2}\left(\mathrm{NH}_{3}\right)\left(\mathrm{H}_{2} \mathrm{O}\right)^{3+}$ & & & & Complicated $\left[\mathrm{H}^{+}\right]$dependence & \\
\hline cis- $\mathrm{Co}\left(\mathrm{NH}_{3}\right)_{4}\left(\mathrm{H}_{2} \mathrm{O}\right)_{2}^{3+}$ & $3 \times 10^{-4}$ & $0.2 \mathrm{M}(\mathrm{H}, \mathrm{Li}) \mathrm{ClO}_{4}$ & 25 & $\begin{array}{l}\mathrm{k}^{\prime \prime}=210 \pm 2+(0.47 \pm 0.03)\left[\mathrm{H}^{+}\right]^{-1} M^{-1} \mathrm{sec}^{-1} \\
\Delta \mathrm{H}^{*}=15.4 \pm 0.02(3.67 \pm 0.04) \text { at } \mu=2 M\end{array}$ & 115 \\
\hline $\mathrm{Cr}^{3+}$ (aquo) & $10^{-3}$ & $0.2 \mathrm{M}(\mathrm{H}, \mathrm{Li}) \mathrm{ClO}_{4}$ & 25 & $\mathrm{k}^{\prime \prime}=\left(6.0\left[\mathrm{H}^{+}\right]^{-1}+0.19\left[\mathrm{H}^{+}\right]^{-2}\right) \times 10^{-3} M^{-1} \mathrm{sec}^{-1}$ & 160 \\
\hline $\mathrm{CrCl}^{2+}$ & $10^{-3}$ & $0.2 \mathrm{M}(\mathrm{H}, \mathrm{Li}) \mathrm{ClO}_{4}$ & 25 & $\mathrm{k}^{\prime \prime}=0.48\left[\mathrm{H}^{+}\right]^{-1} M^{-1} \sec ^{-1}$ & 160 \\
\hline $\mathrm{CrBr}^{2+}$ & $10^{-3}$ & $0.2 \mathrm{M}(\mathrm{H}, \mathrm{Li}) \mathrm{ClO}_{4}$ & 25 & $\mathrm{k}^{\prime \prime}=1.42\left[\mathrm{H}^{+}\right]^{-1} M^{-1} \mathrm{sec}^{-1}$ & 160 \\
\hline $\mathrm{CrF}^{2+}$ & $10^{-3}$ & $0.2 \mathrm{M}(\mathrm{H}, \mathrm{Li}) \mathrm{ClO}_{4}$ & 25 & $\mathrm{k}^{\prime \prime}=17+0.31\left[\mathrm{H}^{+}\right]^{-1} M^{-1} \mathrm{sec}^{-1}$ & 160 \\
\hline $\mathrm{CrN}_{3}^{3+}$ & $10^{-3}$ & $0.2 \mathrm{M}(\mathrm{H}, \mathrm{Li}) \mathrm{ClO}_{4}$ & 25 & $\mathrm{k}^{\prime \prime}=40+0.41\left[\mathrm{H}^{+}\right]^{-1} M^{-1} \sec ^{-1}$ & 160 \\
\hline $\mathrm{CrNCS}^{2+}$ & $10^{-3}$ & $0.2 \mathrm{M}(\mathrm{H}, \mathrm{Li}) \mathrm{ClO}_{4}$ & 25 & $\mathrm{k}^{\prime \prime}=\left(14\left[\mathrm{H}^{+}\right]^{-1}+0.74\left[\mathrm{H}^{+}\right]^{-2}\right) \times 10^{-3} M^{-1} \mathrm{sec}^{-1}$ & 160 \\
\hline $\mathrm{CrSCN}^{2+}$ & $10^{-3}$ & $0.2 \mathrm{M}(\mathrm{H}, \mathrm{Li}) \mathrm{ClO}_{4}$ & 25 & $\mathrm{k}^{\prime \prime}=9 \times 10^{3} M^{-1} \mathrm{sec}^{-1}$ & 160 \\
\hline$c i s-\mathrm{CrCl}_{2}^{+}$ & $10^{-3}$ & $0.2 \mathrm{M}(\mathrm{H}, \mathrm{Li}) \mathrm{ClO}_{4}$ & 25 & $\mathrm{k}^{\prime \prime}=51+4.35\left[\mathrm{H}^{+}\right]^{-1} M^{-1} \sec ^{-1}$ & 160 \\
\hline trans $-\mathrm{CrCl}_{2}^{+}$ & $10^{-3}$ & $0.2 \mathrm{M}(\mathrm{H}, \mathrm{Li}) \mathrm{ClO}_{4}$ & 25 & $\mathrm{k}^{\prime \prime}=44+5.5\left[\mathrm{H}^{+}\right]^{-1} M^{-1} \mathrm{sec}^{-1}$ & 160 \\
\hline $\mathrm{Cr}\left(\mathrm{NH}_{3}\right)_{5} \mathrm{Cl}^{2+}$ & $10^{-3}$ & $0.2 \mathrm{M}(\mathrm{H}, \mathrm{Li}) \mathrm{ClO}_{4}$ & 25 & $\mathrm{k}^{\prime \prime}=8 \times 10^{-3}$ & 161 \\
\hline \multirow{8}{*}{$\mathrm{H}_{2} \mathrm{O}\left(\right.$ or $\left.\mathrm{H}^{+}\right)$} & 55.5 & $10^{-4} \mathrm{M} \mathrm{HCl}$ & 22 & $\mathrm{k}=4.27 \times 10^{-4} \mathrm{sec}^{-1}$ & 161 \\
\hline & 55.5 & $0.5 M \mathrm{HCl}$ & 22 & $\mathrm{k}=1.84 \times 10^{-3} \mathrm{sec}^{-1} ;$ rate increased by $\mathrm{LiCl}$ & 161 \\
\hline & 55.5 & $8.3 M \mathrm{HCl}$ & 22 & $\mathrm{k}=2.9 \times 10^{-4} \mathrm{sec}^{-1}$ & 161 \\
\hline & & & & $\mathrm{E}_{\mathrm{a}}=42(10)$ in $6 \mathrm{M} \mathrm{HCl}$ & \\
\hline & 55.5 & $0.25 \mathrm{M} \mathrm{H}_{2} \mathrm{SO}_{4}$ & 22 & $\begin{array}{l}\mathrm{k}=8.52 \times 10^{-7} \mathrm{sec}^{-1} \\
\mathrm{E}_{\mathrm{a}}=54(13)\end{array}$ & 159 \\
\hline & 55.5 & $4.0 \mathrm{M} \mathrm{H}_{2} \mathrm{SO}_{4}$ & 22 & $\mathrm{k}=4.66 \times 10^{-5} \mathrm{sec}^{-1}$ & 159 \\
\hline & 55.5 & $0.05 \mathrm{M} \mathrm{H}_{2} \mathrm{SO}_{4}$ & 20 & $\mathrm{k}=1.7 \times 10^{-6} \mathrm{sec}^{-1}$ & 162 \\
\hline & & & & $\mathrm{E}_{\mathrm{a}}=30(7.1)$ & \\
\hline $\mathrm{UO}_{2}^{+}$ & $10^{-5}$ & $0.1 M \mathrm{HClO}_{4}$ & 25 & $\begin{array}{l}\mathrm{k}^{\prime \prime}=(5.0 \pm 0.2) \times 10^{4}\left[\mathrm{H}^{+}\right]^{0} M^{\mathrm{I}} \mathrm{sec}^{-1} \\
\Delta \mathrm{H}^{*}=8(2)\end{array}$ & 76 \\
\hline $\mathrm{UO}_{2}^{2+}$ & $2.5 \times 10^{-5}$ & $0.1 \mathrm{M} \mathrm{HClO}_{4}$ & 25 & $\begin{array}{l}\mathrm{k}^{\prime \prime}=(1.20 \pm 0.04) \times 10^{4}\left[\mathrm{H}^{+}\right]^{0} M^{-1} \mathrm{sec}^{-1} \\
\Delta \mathrm{H}^{*}=17.4(4.15)\end{array}$ & 76 \\
\hline
\end{tabular}


Table $\mathbf{1 0 . 2}$

OXIDATION OF URANIUM(IV)

\begin{tabular}{|c|c|c|c|c|c|}
\hline Agent & $\begin{array}{l}\text { Typical } \\
\text { concentration, } M\end{array}$ & Solution & $\begin{array}{l}\text { Temp. } \\
{ }^{\circ} \mathrm{C}\end{array}$ & Results & Ref. \\
\hline $\mathrm{Br}_{2}$ & 0.07 & $\begin{array}{l}2 M(\mathrm{H}, \mathrm{Na}) \mathrm{ClO}_{4} \\
1 M \mathrm{Na}\left(\mathrm{Br}, \mathrm{ClO}_{4}\right)\end{array}$ & 25 & $\begin{array}{l}\mathrm{k}^{\prime \prime}=5.3 \times 10^{-4}\left[\mathrm{H}^{+}\right]^{-2} M^{-1} \sec ^{-1} \\
\text { Catalyzed by Fe(III) and Mn(II) }\end{array}$ & 163 \\
\hline $\mathrm{BrO}_{3}^{-}$ & $4 \times 10^{-3}$ & $4 M(\mathrm{H}, \mathrm{Na}) \mathrm{ClO}_{4}$ & 25 & $\begin{array}{l}\mathrm{k}^{\prime \prime}=0.41+0.14\left[\mathrm{H}^{+}\right]^{2} M^{-1} \sec ^{-1} \\
\Delta \mathrm{H}^{*}=115 \pm 0.4(27.6 \pm 0.1) \text { and } \\
95 \pm 0.4(22.8 \pm 0.1) \text { for the respective rate constants }\end{array}$ & 142 \\
\hline $\mathrm{Ce}(\mathrm{IV})$ & $5 \times 10^{-5}$ & $2 \mathrm{M}(\mathrm{H}, \mathrm{Na}) \mathrm{ClO}_{4}$ & 25 & $\begin{array}{l}\mathrm{k}^{\prime \prime}=8.7 \times 10^{3}\left[\mathrm{H}^{+}\right]^{-1.2} M^{-1} \mathrm{sec}^{-1} \\
\mathrm{E}_{\mathrm{a}}=64 \pm 3(15.4 \pm 0.7) \\
\text { Rates are lower in solutions of tributyl phosphate } \\
\text { Reaction also studied in acidic sulfate media } \\
\mathrm{E}_{\mathrm{a}}=71 \pm 2(17 \pm 0.4)\end{array}$ & $\begin{array}{l}123 \\
164 \\
165\end{array}$ \\
\hline $\mathrm{ClO}_{3}^{-}$ & 0.075 & $0.5 M(\mathrm{H}, \mathrm{Na}) \mathrm{ClO}_{4}$ & Room & $\begin{array}{l}\mathrm{k}^{\prime \prime}=2.9 \times 10^{-3}\left[\mathrm{H}^{+}\right] M^{-1} \sec ^{-1} \\
\text { Catalyzed by } \mathrm{Fe}(\mathrm{II}) \text { and } \mathrm{V}(\mathrm{V})\end{array}$ & $\begin{array}{l}166 \\
167\end{array}$ \\
\hline $\mathrm{Fe}^{3+}$ & $2 \times 10^{-4}$ & $1 M(\mathrm{H}, \mathrm{Na}) \mathrm{ClO}_{4}$ & 25 & $\begin{array}{l}\mathrm{k}^{\prime}=2.98\left[\mathrm{H}^{+}\right]^{-1}+10.6\left[\mathrm{H}^{+}\right]^{-2} M^{-1} \mathrm{sec}^{-1} \\
\mathrm{E}_{\mathrm{a}}=77 \pm 11(18.5 \pm 2.6) \text { and } 103 \pm 2(24.7 \pm 0.5) \\
\text { for the respective rate constants } \dagger \\
\text { Rate is increased in aqueous solutions of } \mathrm{CH}_{3} \mathrm{OH}, \mathrm{C}_{2} \mathrm{H}_{5} \mathrm{OH} \text {, } \\
\text { or }\left(\mathrm{CH}_{3}\right)_{2} \mathrm{CO} \\
\text { Also studied in } \mathrm{HNO}_{3} \text { by a catalytic method } \\
\text { Effect of sulfate determined }\end{array}$ & $\begin{array}{l}168 \\
169 \\
190\end{array}$ \\
\hline $\mathrm{Fe}(\mathrm{CN})_{6}^{3-}$ & $10^{-3}$ & $2 \mathrm{M}(\mathrm{H}, \mathrm{Na}) \mathrm{ClO}_{4}$ & 25 & $\begin{array}{l}\mathrm{k}^{\prime \prime}=3.2\left[\mathrm{H}^{+}\right]^{-1} M^{-1} \sec ^{-1} \\
\Delta \mathrm{H}^{*}=71 \pm 4(16.9 \pm 0.9) \\
\text { Rate is inhibited by } \mathrm{Cl}^{-} \\
\text {Rate decreased significantly in } \mathrm{D}_{2} \mathrm{O} \text { solutions }\end{array}$ & 170 \\
\hline $\mathrm{HClO}_{2}$ & 0.1 & $\begin{array}{l}2 M(\mathrm{H}, \mathrm{Na}) \mathrm{ClO}_{4} \\
0.1 M \mathrm{C}_{6} \mathrm{H}_{5} \mathrm{OH}\end{array}$ & 25 & $\begin{array}{l}\mathrm{k}^{\prime \prime}=(291 \pm 4)\left(1+4\left[\mathrm{HClO}_{2}\right]\right)^{-1}\left(1+21\left[\mathrm{H}^{+}\right]\right)^{-1} M^{-1} \sec ^{-1} \\
\Delta \mathrm{H}^{*}=107 \pm 1(25.5 \pm 0.3) \text { for the second-order rate } \\
\text { constant }\end{array}$ & $65 a$ \\
\hline
\end{tabular}


Phenol scavenges the $\mathrm{Cl}(\mathrm{I})$ species and forms

chlorophenols; the rate is independent of $\left[\mathrm{C}_{6} \mathrm{H}_{5} \mathrm{OH}\right]$

Also studied in $\mathrm{H}_{2} \mathrm{SO}_{4}$

$65 b$

\begin{tabular}{|c|c|c|}
\hline $\mathrm{HCrO}_{4}^{-}$ & $\begin{array}{l}3 \times 10^{-5} \\
\left(\mathrm{U}^{4+} \text { in excess }\right)\end{array}$ & $3 M(\mathrm{H}, \mathrm{Li}) \mathrm{ClO}_{4}$ \\
\hline $\mathrm{HNO}_{2}$ & 0.03 & $3 M(\mathrm{H}, \mathrm{Na}) \mathrm{NO}_{3}$ \\
\hline $\mathrm{H}_{2} \mathrm{O}_{2}$ & $2 \times 10^{-3}$ & $2 M(\mathrm{H}, \mathrm{Li}) \mathrm{ClO}_{4}$ \\
\hline$N p(V)$ & $2 \times 10^{-3}$ & $1 M(\mathrm{H}, \mathrm{Na}) \mathrm{ClO}_{4}$ \\
\hline$N p(V I)$ & $8 \times 10^{-4}$ & $2 \mathrm{M}(\mathrm{H}, \mathrm{Na}) \mathrm{ClO}_{4}$ \\
\hline $\mathrm{O}_{2}$ & $10^{-3}$ & $1 M(\mathrm{H}, \mathrm{Na}) \mathrm{ClO}_{4}$ \\
\hline $\mathrm{Pu}^{4+}$ & $2 \times 10^{-3}$ & $2 \mathrm{M}(\mathrm{H}, \mathrm{Li}) \mathrm{ClO}_{4}$ \\
\hline
\end{tabular}

$\mathrm{k}^{\prime}=\left(0.85+8.76\left[\mathrm{H}^{+}\right]^{-1}\right) \times 10^{4} M^{-1} \mathrm{sec}^{-1}$

The reaction induces the oxidation of $\mathrm{I}^{-}$

Reaction catalyzed by $(0.5-10) \times 10^{-3} M \mathrm{Fe}(\mathrm{III})$

$-\mathrm{d}[\mathrm{U}(\mathrm{IV})] / \mathrm{dt}=(1.01 \pm 0.02) \times 10^{3}[\mathrm{U}(\mathrm{IV})][\mathrm{Fe}(\mathrm{III})]\left[\mathrm{HNO}_{2}\right]^{0}$

$\left[\mathrm{H}^{+}\right]^{-1.15} \mathrm{M} \sec ^{-1}$

$\mathrm{E}_{\mathbf{a}}=74(17.8)$

Uncatalyzed reaction is much slower

$\mathrm{k}^{\prime \prime}=1\left[\mathrm{H}^{+}\right]^{-0.21} M^{-1} \mathrm{sec}^{-1}$

$\mathrm{E}_{\mathrm{a}}=67-79(16-19)$

Reaction is inhibited by $\mathrm{Cu}($ II) and $\mathrm{Co}(\mathrm{II})$

Higher rates have been reported

$-\mathrm{d}[\mathrm{U}(\mathrm{IV})] / \mathrm{dt}=\mathrm{k}_{1}[\mathrm{~Np}(\mathrm{~V})][\mathrm{U}(\mathrm{IV})]+\mathrm{k}_{2}[\mathrm{~Np}(\mathrm{IV})][\mathrm{U}(\mathrm{IV})]$

For $\left[\mathrm{H}^{+}\right]=0.1 M$

$\mathrm{k}_{1}=8.3 \times 10^{-4} M^{-1} \mathrm{sec}^{-1}$

$\mathrm{k}_{2}=5.3 \times 10^{-3} M^{-1} \mathrm{sec}^{-1}$

$\mathrm{E}_{\mathrm{a}}=134 \pm 8(32 \pm 2)$ and $63 \pm 13(15 \pm 3)$ for the respective

rate constants

Reaction is catalyzed by $\mathrm{Cl}^{-}$

$\mathrm{k}^{\prime}=21.7\left[\mathrm{H}^{+}\right]^{-1} M^{-1} \mathrm{sec}^{-1}$

$\Delta \mathrm{H}^{*}=76 \pm 1(18.2 \pm 0.2)$

Deuterium isotope effect given by $\mathrm{k}_{\mathrm{H}} / \mathrm{k}_{\mathrm{D}}=1.6$

$\mathrm{k}^{\prime}=\left(1.49\left[\mathrm{H}^{+}\right]^{-1}+0.24\left[\mathrm{H}^{+}\right]^{-2}\right) \times 10^{-2} M^{-1} \mathrm{sec}^{-1}$

$\mathrm{E}_{\mathrm{a}}=81 \pm 4(19.3 \pm 1)$ in $0.95 \mathrm{M} \mathrm{HClO}_{4}$

Reaction is inhibited by $\mathrm{Cl}^{-}, \mathrm{Ag}^{+}$, and $\mathrm{Fe}^{2+}$ and catalyzed

by $\mathrm{Cu}^{2+}$ and $\mathrm{Hg}^{2+}$

$\mathrm{k}^{\prime}=34\left[\mathrm{H}^{+}\right]^{-2} M^{-1} \sec ^{-1}$

$\Delta \mathrm{H}^{*}=102 \pm 2.5(24.3 \pm 0.6)$

Reaction is catalyzed by $\mathrm{P}_{2} \mathrm{O}_{7}^{4-}, \mathrm{PO}_{4}^{3-}, \mathrm{SO}_{4}^{2-}$, and $\mathrm{Cr}^{3+}$ 
Table 10.2 (Continued)

\begin{tabular}{|c|c|c|c|c|c|}
\hline Agent & $\begin{array}{c}\text { Typical } \\
\text { concentration, } M\end{array}$ & Solution & $\begin{array}{l}\text { Temp., } \\
{ }^{\circ} \mathrm{C}\end{array}$ & Results & Ref. \\
\hline $\mathrm{Pu}(\mathrm{Vl})$ & $2 \times 10^{-4}$ & $2 \mathrm{M}(\mathrm{H}, \mathrm{Li}) \mathrm{ClO}_{4}$ & 25 & $\begin{array}{l}\mathrm{k}^{\prime \prime}=\frac{\mathrm{k}_{1}}{\left(1+\left\{\mathrm{k}_{1}\left[\mathrm{H}^{+}\right]\right\} / \mathrm{k}_{2}\right)\left(\left[\mathrm{H}^{+}\right]+\mathrm{K}\right)} \\
\mathrm{k}_{1}=4.4 \sec ^{-1} ; \mathrm{k}_{2}=11 M \sec ^{-1} ; \mathrm{K}=0.024 M \\
\Delta \mathrm{H}^{*}=74 \pm 2(17.6 \pm 0.4) \text { and } 90 \pm 1(21.4 \pm 0.3) \text { for } \\
\text { the respective rate constants } \\
\text { Rate law shows evidence for consecutive reactions and } \\
\text { a metastable intermediate }\end{array}$ & 61 \\
\hline $\mathrm{S}_{2} \mathrm{O}_{8}^{2-}$ & 0.03 & $0.5 \mathrm{M} \mathrm{H}_{2} \mathrm{SO}_{4}$ & Room & $\mathrm{k}^{\prime \prime}=7.2 \times 10^{-3}\left[\mathrm{H}^{+}\right]^{0} M^{-1} \mathrm{sec}^{-1}$ & 176 \\
\hline \multirow[t]{4}{*}{$\mathrm{Tl}^{3+}$} & 0.01 & $2.9 M(\mathrm{H}, \mathrm{Na}) \mathrm{ClO}_{4}$ & 25 & $\begin{array}{l}\mathrm{k}^{\prime}=\left(2.11\left[\mathrm{H}^{+}\right]^{-1}+2.13\left[\mathrm{H}^{+}\right]^{-2}\right) \times 10^{-2} M^{-1} \mathrm{sec}^{-1} \\
\Delta \mathrm{H}^{*}=103 \pm 8(24.6 \pm 2) \text { and } 91 \pm 8(21.7 \pm 2) \text { for the respective } \\
\text { rate constants }\end{array}$ & 122 \\
\hline & & & & $\begin{array}{l}\text { Reaction is catalyzed by } \mathrm{Fe}(\mathrm{III}) \text {; tartaric acid increases } \\
\text { rate and causes departure from second-order kinetics }\end{array}$ & 177 \\
\hline & & & & $\mathrm{CH}_{3} \mathrm{OH}$ causes departure from second-order kinetics & 178 \\
\hline & & & & $\begin{array}{l}\text { Second-order rate law not followed over wide ranges in } \\
\text { reactant concentrations }\end{array}$ & 179 \\
\hline \multirow[t]{3}{*}{$\mathrm{U}(\mathrm{VI})$} & 0.03 & $\mathrm{Cl}^{-}$solutions & 25 & $\begin{array}{l}\text { Exchange rate }=1.2 \times 10^{-5}[\mathrm{U}(\mathrm{IV})]^{2}[\mathrm{U}(\mathrm{VI})]\left[\mathrm{H}^{+}\right]^{-3} M \mathrm{sec}^{-1} \\
\mathrm{E}_{\mathfrak{a}}=140 \pm 3(33.4 \pm 0.8) \text { for } \mathrm{pH}=0.85\end{array}$ & 126 \\
\hline & 0.005 & $2 M(\mathrm{H}, \mathrm{Na}) \mathrm{ClO}_{4}$ & 25 & $\begin{array}{l}\mathrm{k}^{\prime} \text { (for exchange) }=2.13 \times 10^{-7}\left[\mathrm{H}^{+}\right\}^{-3} M^{-1} \sec ^{-1} \\
\text { Low concentration of } \mathrm{U}(\mathrm{IV}) \text { used to minimize the contribution } \\
\text { of the }[\mathrm{U}(\mathrm{IV})]^{2} \text { term } \\
\mathrm{E}_{\mathrm{a}}=159 \pm 2(38.1 \pm 0.5) \\
\text { Exchange is induced by } \mathrm{UV} \text { light; quantum yield } \\
\text { is about } 0.01\end{array}$ & 180 \\
\hline & & & & Also studied in sulfate (181) and in aqueous $\mathrm{HCl}$-ethanol solutions & 182 \\
\hline
\end{tabular}

$\nmid$ Original data recalculated. 
Table 10.3

\section{OXIDATION OF URANIUM(V)}

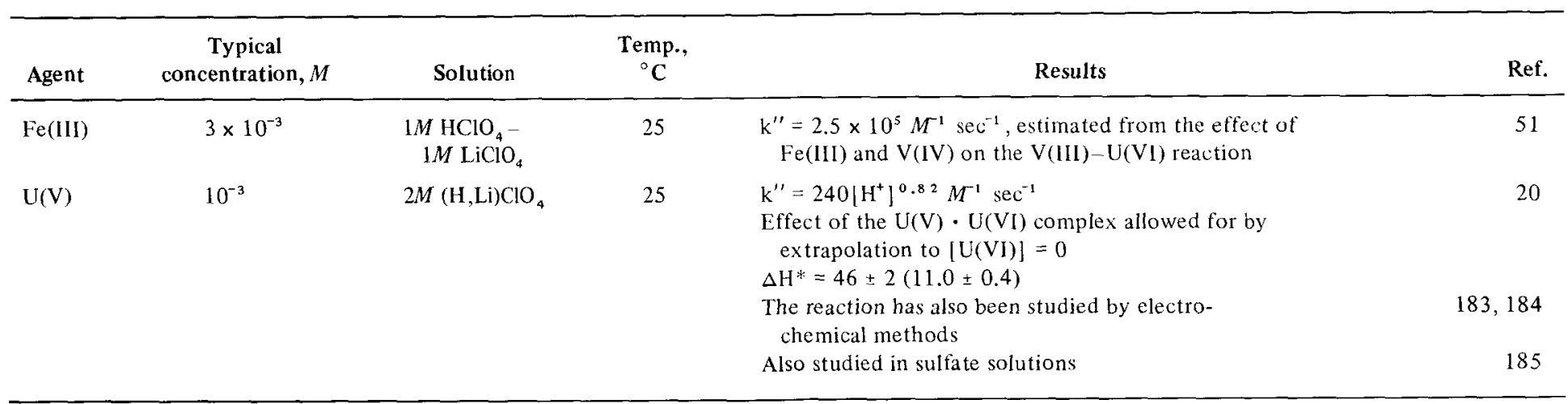

Table 10.4

REDUCTION OF URANIUM(V)

\begin{tabular}{ccccc}
\hline Agent & $\begin{array}{c}\text { Typical } \\
\text { concentration, } M\end{array}$ & Solution & $\begin{array}{c}\text { Temp., } \\
{ }^{\circ} \mathrm{C}\end{array}$ & Results \\
\hline $\mathrm{Cr}(\mathrm{II})$ & 0.06 & $2 M(\mathrm{H}, \mathrm{Na}) \mathrm{ClO}_{4}$ & 20 & $\begin{array}{l}\mathrm{k}^{\prime \prime}=(416 \pm 15) \exp \left(0.16 \mid \mathrm{H}^{+} \mathrm{J}\right) M^{-1} \sec ^{-1} \\
\Delta \mathrm{H}^{*}=13 \pm 1.2(3.2 \pm 0.3) \\
\mathrm{The} \mathrm{U}(\mathrm{V}) \text { is in the form of the U(V) } \operatorname{Cr}(\mathrm{III}) \operatorname{complex}\end{array}$ \\
\hline
\end{tabular}


Table 10.5

REDUCTION OF URANIUM(VI)

\begin{tabular}{|c|c|c|c|c|c|}
\hline Agent & $\begin{array}{c}\text { Typical } \\
\text { concentration, } M\end{array}$ & Solution & $\begin{array}{l}\text { Temp. } \\
{ }^{\circ} \mathrm{C}\end{array}$ & Results & Ref. \\
\hline $\mathrm{Cr}(\mathrm{II})$ & $2.5 \times 10^{-3}$ & $2 \mathrm{M}(\mathrm{H}, \mathrm{Na}) \mathrm{ClO}_{4}$ & 25 & $\begin{array}{l}\mathrm{k}^{\prime \prime}=1.42 \times 10^{4}\left[\mathrm{H}^{+}\right]^{0} M^{-1} \mathrm{sec}^{-1} \\
\mathrm{E}_{\mathrm{a}}=5.8 \pm 1.7(1.4 \pm 0.4) \\
\mathrm{A} C r(\mathrm{III}) \cdot \mathrm{U}(\mathrm{V}) \text { complex is formed }\end{array}$ & 130 \\
\hline $\mathrm{Eu}(\mathrm{II})$ & $4.7 \times 10^{-4}$ & $2 \mathrm{M}(\mathrm{H}, \mathrm{Na}) \mathrm{ClO} \mathrm{O}_{4}$ & 20 & $\begin{array}{l}\mathrm{k}^{\prime \prime}=1.43 \times 10^{4} \exp \left(0.15\left[\mathrm{H}^{+}\right]\right) \mathrm{M}^{-1} \mathrm{sec}^{-1} \\
\Delta \mathrm{H}^{*}=6.3 \pm 1.3(1.5 \pm 0.3) \\
\text { Reaction is catalyzed by added sulfate; rate is } \\
\text { nearly tripled by } 0.003 \mathrm{MSO}_{4}^{2-}\end{array}$ & 131 \\
\hline $\begin{array}{l}\text { Fe(II) } \\
\text { Np(III) }\end{array}$ & & $3.7 M \mathrm{H}_{3} \mathrm{PO}_{4}$ & 25 & $\begin{array}{l}\mathrm{t}_{1 / 2}=160 \text { to } 170 \mathrm{~min} ;[\mathrm{Fe}(\mathrm{II})] \text { not specified } \\
(\text { See Table } 10.6)\end{array}$ & 186 \\
\hline $\operatorname{Sn}(I I)$ & 1 & $1 M \mathrm{HCl}$ & 30 & $\begin{array}{l}\mathrm{k}^{\prime \prime}=2.75 \times 10^{-3} M^{-1} \mathrm{hr}^{-1} \\
\mathrm{E}_{\mathrm{a}}=76(18) \\
\text { Rate increases with increasing } \mathrm{HCl} \\
\quad \text { concentration } \\
\text { Evidence for optical interaction absorption }\end{array}$ & 188 \\
\hline $\operatorname{Ti}(111)$ & $2 \times 10^{-3}$ & $0.5 \mathrm{M}(\mathrm{H}, \mathrm{Li}) \mathrm{ClO}_{4}$ & 25 & $\begin{array}{l}\mathrm{k}^{\prime \prime}=13.7\left(\left[\mathrm{H}^{+}\right]+0.0136\right)^{-1} M^{-1} \mathrm{sec}^{-1} \\
\mathrm{E}_{\mathrm{a}} \text { unknown } \\
{\left[\mathrm{Cl} \mathrm{l}^{-}\right] \text {has no effect up to } 0.3 \mathrm{M}} \\
\text { Reaction is inhibited by } \mathrm{V}(\mathrm{IV}) \text {, which is } \\
\text { reduced to } \mathrm{V}(\mathrm{III})\end{array}$ & 189 \\
\hline V(II) & $1.5 \times 10^{-3}$ & $2 \mathrm{M}(\mathrm{H}, \mathrm{Li}) \mathrm{ClO}_{4}$ & 25 & $\begin{array}{l}\mathrm{k}^{\prime \prime}=73 M^{-1} \mathrm{sec}^{-1} \\
\Delta \mathrm{H}^{*}=29.7 \pm 0.4(7.1 \pm 0.1)\end{array}$ & 49 \\
\hline V(III) & $3 \times 10^{-3}$ & $2 \mathrm{M}(\mathrm{H}, \mathrm{Li}) \mathrm{ClO}_{4}$ & 25 & $\begin{array}{l}\mathrm{k}^{\prime \prime}=0.28\left[\mathrm{H}^{+}\right]^{-1.8} M^{-1} \mathrm{sec}^{-1} \\
{\left[\mathrm{H}^{+}\right] \text {dependence suggests consecutive reactions }} \\
\text { and a binuclear intermediate } \\
\mathrm{E}_{\mathrm{a}}=92.5 \pm 0.4(22.1 \pm 0.1) \text { for } 1 M \mathrm{H}^{+}\end{array}$ & 51 \\
\hline
\end{tabular}


Table 10.6

OXIDATION OF NEPTUNIUM(III)

\begin{tabular}{|c|c|c|c|c|c|}
\hline Agent & $\begin{array}{c}\text { Typical } \\
\text { concentration, } M\end{array}$ & Solution & $\begin{array}{l}\text { Temp. } \\
{ }^{\circ} \mathrm{C}\end{array}$ & Results & Ref. \\
\hline $\mathrm{Co}\left(\mathrm{NH}_{3}\right)_{4}\left(\mathrm{H}_{2} \mathrm{O}\right)_{2}^{3+}$ & $5 \times 10^{-2}$ & $2 M(\mathrm{H}, \mathrm{Li}) \mathrm{ClO}_{4}$ & 25 & $\mathrm{k}^{\prime \prime}=4.4 \times 10^{-3}+9 \times 10^{-3}\left[\mathrm{H}^{+}\right]^{-1} M^{-1} \sec ^{-1}$ & 115 \\
\hline $\mathrm{Fe}(\mathrm{III})$ & $10^{-3}$ & $2 \mathrm{M}(\mathrm{H}, \mathrm{Li}) \mathrm{ClO}_{4}$ & 25 & $\begin{array}{l}\mathrm{k}^{\prime \prime}=676\left[\mathrm{H}^{+}\right]^{-0.94} M^{-1} \mathrm{sec}^{-1} \\
\Delta \mathrm{H}^{*}=60.9 \pm 0.4(14.6 \pm 0.1)\end{array}$ & 114 \\
\hline $\mathrm{FeCl}^{2+}$ & $4 \times 10^{-5}$ & $\begin{array}{l}1.96 \mathrm{M} \mathrm{HClO}_{4}- \\
0.04 \mathrm{M} \mathrm{HCl}\end{array}$ & 1 & $\mathrm{k}^{\prime}=3.4 \times 10^{3}\left[\mathrm{H}^{+}\right]^{0} M^{-1} \mathrm{sec}^{-1}$ & 191 \\
\hline $\mathrm{H}_{2} \mathrm{O}_{2}$ & $3.5 \times 10^{-4}$ & $1 M \mathrm{HClO}_{4}$ & 25 & $\begin{array}{l}\mathrm{k}^{\prime \prime}=35 \pm 3 M^{-1} \mathrm{sec}^{-1} \\
\mathrm{~Np}(\mathrm{~V}) \text { apparently forms in first step }\end{array}$ & 192 \\
\hline $\mathrm{NpO}_{2}^{+}$ & $6 \times 10^{-4}$ & $\begin{array}{l}0.25 M \mathrm{HClO}_{4}- \\
1.75 \mathrm{M} \mathrm{NaClO}_{4} \\
0.25 \mathrm{M}(\mathrm{H}, \mathrm{Li}) \mathrm{ClO}_{4}\end{array}$ & 25 & $\begin{array}{l}\mathrm{k}^{\prime \prime}=43\left[\mathrm{H}^{+}\right]^{1.05} M^{-1} \mathrm{sec}^{-1} \\
\mathrm{k}^{\prime \prime}=1.0+14.3\left[\mathrm{H}^{+}\right] M^{-1} \mathrm{sec}^{-1}\end{array}$ & $\begin{array}{l}79 \\
63\end{array}$ \\
\hline $\mathrm{NpO}_{2}^{2+}$ & $7 \times 10^{-6}$ & $0.1 M \mathrm{HClO}_{4}$ & 25 & $\begin{array}{l}\mathrm{k}^{\prime \prime}=2.2 \times 10^{4}\left[\mathrm{H}^{+}\right]^{0} M^{-1} \mathrm{sec}^{-1} \\
\Delta \mathrm{H}^{*} \approx 4(1)\end{array}$ & 76 \\
\hline $\mathrm{O}_{2}$ & Saturated & $1 \mathrm{M} \mathrm{HClO}_{4}$ & 25 & Complete in $10 \mathrm{sec}$ & 192 \\
\hline $\mathrm{Ru}\left(\mathrm{NH}_{3}\right)_{5} \mathrm{OH}_{2}^{3+}$ & $1.2 \times 10^{-2}$ & $1 M(\mathrm{H}, \mathrm{Li}) \mathrm{O}_{3} \mathrm{SCF}_{3}$ & 25 & $\begin{array}{l}\mathrm{k}^{\prime \prime}(\text { forward })=0.27\left[\mathrm{H}^{+}\right]^{0} M^{-1} \mathrm{sec}^{-1} \\
\Delta \mathrm{H}^{*}=17.7 \pm 1(4.24 \pm 0.25) \\
\text { Reverse reaction important, } \mathrm{Q}=0.062\end{array}$ & 116 \\
\hline $\mathrm{Ru}\left(\mathrm{NH}_{3}\right)_{6}^{3+}$ & $1.9 \times 10^{-2}$ & $0.5 M(\mathrm{H}, \mathrm{Li}) \mathrm{O}_{3} \mathrm{SCF}_{3}$ & 25 & $\begin{array}{l}\mathrm{k}^{\prime \prime}(\text { forward })=0.305\left[\mathrm{H}^{+}\right]^{0} M^{-1} \mathrm{sec}^{-1} \\
\Delta \mathrm{H}^{*}=16 \pm 4(3.9 \pm 1) \\
\text { Reverse reaction important, } \mathrm{Q}=0.031\end{array}$ & 116 \\
\hline $\mathrm{UO}_{2}^{+}$ & $2 \times 10^{-4}$ & $1 \mathrm{M} \mathrm{HClO}_{4}$ & 25 & $\begin{array}{l}\mathrm{k}^{\prime \prime}=38\left[\mathrm{H}^{+}\right] M^{-1} \mathrm{sec}^{-1} \\
\Delta \mathrm{H}^{*}=21 \pm 0.8(5.1 \pm 0.2)\end{array}$ & 12 \\
\hline $\mathrm{UO}_{2}^{2+}$ & $1.5 \times 10^{-3}$ & $1 M \mathrm{HClO}_{4}$ & 25 & $\begin{array}{l}\mathrm{k}^{\prime \prime}=39\left[\mathrm{H}^{+}\right]^{-0.13} \\
\Delta \mathrm{H}^{*}=11 \pm 0.7(2.6 \pm 0.16)\end{array}$ & 12 \\
\hline
\end{tabular}


Table 10.7

OXIDATION OF NEPTUNIUM(IV)

\begin{tabular}{|c|c|c|c|c|c|}
\hline Agent & $\begin{array}{c}\text { Typical } \\
\text { concentration, } M\end{array}$ & Solution & $\begin{array}{l}\text { Temp., } \\
{ }^{\circ} \mathrm{C}\end{array}$ & Results & Ref. \\
\hline $\operatorname{Ag}($ II $)$ & & & Room & Very rapid & 157 \\
\hline $\mathrm{BrO}_{3}^{-}$ & 0.09 & $1 M \mathrm{H}_{2} \mathrm{SO}_{4}$ & 25 & $\begin{array}{l}\text { Initial } \mathrm{k}^{\prime \prime} \approx 6 \times 10^{-4} M^{-1} \mathrm{sec}^{-1} \\
\text { Catalyzed by } \mathrm{Np}(\mathrm{V}) \text { and } \mathrm{Ce}(\mathrm{III})\end{array}$ & 157 \\
\hline $\mathrm{Cl}_{2}$ & & $1 M \mathrm{HCl}$ & 25 & Very slow (quite rapid at $75^{\circ} \mathrm{C}$ ) & 157 \\
\hline Fe(III) & $2 \times 10^{-3}$ & $1 M(\mathrm{H}, \mathrm{Na}) \mathrm{ClO}_{4}$ & 25 & $\begin{array}{l}\mathrm{k}^{\prime \prime}=5.7 \times 10^{-2}\left[\mathrm{H}^{+}\right]^{-3} M^{-1} \sec ^{-1} \\
\mathrm{E}_{\mathrm{a}}=146(35) \\
\text { Recent work suggests three parallel paths } \\
\text { Rates are greater in aqueous solutions of } \mathrm{CH}_{3} \mathrm{OH} \text { or } \mathrm{C}_{2} \mathrm{H}_{5} \mathrm{OH}\end{array}$ & $\begin{array}{l}121 \\
193 \\
194\end{array}$ \\
\hline $\mathrm{MnO}_{4}^{-}$ & & $\mathrm{H}_{2} \mathrm{SO}_{4}$ or $\mathrm{HNO}_{3}$ & & Very rapid & 157 \\
\hline \multirow[t]{4}{*}{$\mathrm{Np}(\mathrm{VI})$} & $5 \times 10^{-3}$ & $2 \mathrm{M}(\mathrm{H}, \mathrm{Na}) \mathrm{ClO}_{4}$ & 25 & $\begin{array}{l}\mathrm{k}^{\prime \prime}=4.5 \times 10^{-2}\left[\mathrm{H}^{+}\right]^{-2} M^{-1} \sec ^{-1} \\
\Delta \mathrm{H}^{*}=105 \pm 2.5(25.1 \pm 0.6) \dagger\end{array}$ & 84 \\
\hline & & $2.2 \mathrm{M}(\mathrm{H}, \mathrm{Na}) \mathrm{ClO}_{4}$ & 25 & $\begin{array}{l}\mathrm{HSO}_{4}^{-} \text {causes a maximum in the rate at } 5 \times 10^{-2} \mathrm{M} \\
\mathrm{k}^{\prime \prime}=\left(4.27\left[\mathrm{H}^{+}\right]^{-2}+0.504\left[\mathrm{H}^{+}\right]^{-3}\right) \times 10^{-2} M^{-1} \mathrm{sec}^{-1} \\
\Delta \mathrm{H}^{*}=103 \pm 1.3(24.6 \pm 0.3) \text { in } 0.27 M \mathrm{H}^{+}\end{array}$ & $\begin{array}{r}85 \\
195\end{array}$ \\
\hline & & $2 \mathrm{M}(\mathrm{H}, \mathrm{Na}) \mathrm{ClO}_{4}$ & 25 & $\begin{array}{l}\mathrm{k}^{\prime}=\left(5.69\left[\mathrm{H}^{+}\right]^{-2}+1.52\left[\mathrm{H}^{+}\right]^{-3}\right) \times 10^{-2} M^{-1} \mathrm{sec}^{-1} \\
\Delta \mathrm{H}^{*}=93 \pm 6(22.3 \pm 1.4) \text { and } 145 \pm 21(34.6 \pm 4.6) \\
\text { for the respective rate constants }\end{array}$ & 125 \\
\hline & & & & $\mathrm{NO}_{3}^{-}$causes a maximum in the rate at $0.575 \mathrm{M}$ & 196 \\
\hline $\mathrm{O}_{2}$ & $10^{-3}$ & $0.01 M \mathrm{HClO}_{4}$ & 25 & $\begin{array}{l}\text { Also studied in aqueous alcohol and acetone solutions } \\
\mathrm{k}^{\prime \prime}=9 \times 10^{-3} \mathrm{M}^{-1} \mathrm{sec}^{-1}\end{array}$ & $\begin{array}{l}168 \\
192\end{array}$ \\
\hline & (saturated) & & & & \\
\hline $\mathrm{Pu}(\mathrm{IV})$ & $3 \times 10^{-3}$ & $2 \mathrm{M}(\mathrm{H}, \mathrm{Na}) \mathrm{ClO}_{4}$ & 25 & $\begin{array}{l}\mathrm{k}^{\prime}=0.253\left[\mathrm{H}^{+}\right]^{-3} M^{-1} \sec ^{-1} \\
\Delta \mathrm{H}^{*}=142 \pm 6(33.9 \pm 1.5)\end{array}$ & 81 \\
\hline $\mathrm{Pu}(\mathrm{VI})$ & & $2 \mathrm{M}(\mathrm{H}, \mathrm{Na}) \mathrm{ClO}_{4}$ & 25 & $\begin{array}{l}\mathrm{k}^{\prime \prime}=5 \times 10^{-3}\left[\mathrm{H}^{+}\right]^{-2.3} M^{-1} \sec ^{-1} \\
\Delta \mathrm{H}^{*}=134 \pm 17(32 \pm 4)\end{array}$ & 87 \\
\hline
\end{tabular}

†Original data recalculated. 
Table 10.8

OXIDATION OF NEPTUNIUM(V)

\begin{tabular}{|c|c|c|c|c|c|}
\hline Agent & $\begin{array}{l}\text { Typical } \\
\text { concentration, } M\end{array}$ & Solution & $\begin{array}{l}\text { Temp. } \\
{ }^{\circ} \mathrm{C}\end{array}$ & Results & Ref. \\
\hline $\mathrm{BrO}_{3}^{-}$ & $10^{-3}$ & $3 \mathrm{MH}_{2} \mathrm{SO}_{4}$ & 25 & $\begin{array}{l}-\mathrm{d}\left[\mathrm{BrO}_{3}^{-}\right] \mathrm{dt}=6.1\left[\mathrm{BrO}_{3}^{-}\right]^{2}[\mathrm{~Np}(\mathrm{~V})]^{0} M \mathrm{sec}^{-1} \\
\Delta \mathrm{H}^{*}=77.4 \pm 0.8(18.5 \pm 0.2) \\
\text { Same rate parameters observed when } \mathrm{Mn}(\mathrm{II}) \\
\text { or Ce(III) oxidized } \\
\text { Similar results were obtained in perchlorate solutions; }\left[\mathrm{H}^{+}\right]^{1,5}\end{array}$ & $197 b$ \\
\hline $\mathrm{Ce}(\mathrm{IV})$ & $3 \times 10^{-4}$ & $2 \mathrm{M}(\mathrm{H}, \mathrm{Na}) \mathrm{ClO}_{4}$ & 25 & $\begin{array}{l}\mathrm{k}^{\prime \prime}=9.2 \times 10^{4}\left[\mathrm{H}^{+}\right] M^{-1} \mathrm{sec}^{-1} \\
\Delta \mathrm{H}^{*} \approx 0\end{array}$ & 129 \\
\hline Co(III) & $4 \times 10^{-4}$ & $2.1 \mathrm{M}(\mathrm{H}, \mathrm{Li}) \mathrm{ClO}_{4}$ & 25 & $\begin{array}{l}\mathrm{k}^{\prime \prime}=311\left[\mathrm{H}^{+}\right]^{-0.11} M^{-1} \mathrm{sec}^{-1} \\
\mathrm{E}_{\mathrm{a}}=54 \pm 2.5(12.9 \pm 0.6) \\
\text { Or k" }=282+29\left[\mathrm{H}^{+}\right]^{-1} M^{-1} \mathrm{sec}^{-1} \\
\mathrm{E}_{\mathrm{a}}=52.7 \pm 0.8(12.6 \pm 0.2) \text { for first rate constant } \\
\text { Oxidation of } \mathrm{Np}(\mathrm{V}) \text { in the } \mathrm{Cr}(\mathrm{III}) \cdot \mathrm{Np}(\mathrm{V}) \text { complex also studied: } \\
\mathrm{k}^{\prime \prime}=2.28\left[\mathrm{H}^{+}\right]^{-1.1} \mathrm{M}^{-1} \mathrm{sec}^{-1} \\
\mathrm{E}_{\mathrm{a}}=75 \pm 4(18 \pm 1)\end{array}$ & 47 \\
\hline $\mathrm{Cr}(\mathrm{VI})$ & $3 \times 10^{-4}$ & $2 M(\mathrm{H}, \mathrm{Li}) \mathrm{ClO}_{4}$ & 25 & $\begin{array}{l}\mathrm{k}^{\prime \prime}=4.3\left[\mathrm{H}^{+}\right]^{1.6} /\left\{1+0.76[\mathrm{~Np}(\mathrm{~V} 1)]\left[\mathrm{H}^{+}\right]^{-1.8} /[\mathrm{Np}(\mathrm{V})\} M^{-1} \sec ^{-1}\right. \\
\mathrm{E}_{\mathrm{a}}=48.5(11.6) \text { for first rate constant }\end{array}$ & 143 \\
\hline $\mathrm{MnO}_{4}^{-}$ & & $\mathrm{H}_{2} \mathrm{SO}_{4}$ & Room & Very rapid & 157 \\
\hline $\mathrm{NO}_{3}^{-}$ & 2.9 & $2.9 M \mathrm{HNO}_{3}$ & 20 & $\begin{array}{l}\mathrm{t} 1 / 2=17 \mathrm{~min} ; \text { rate depends on }\left[\mathrm{HNO}_{3}\right]^{4} \\
E_{\mathrm{a}}=50(12) \\
\text { Rate increased by the products of the nitration of nitropropane }\end{array}$ & $\begin{array}{l}198 \\
199\end{array}$ \\
\hline $\mathrm{Np}(\mathrm{VI})$ & $9 \times 10^{-5}$ & $1 M \mathrm{HClO}_{4}$ & 0 & $\begin{array}{l}\mathrm{k}^{\prime \prime}=29 \mathrm{M}^{-1} \mathrm{sec}^{-1} \\
\mathrm{E}_{\mathrm{a}}=35(8.3) \\
\text { Exchange rate unaffected by } \mathrm{NO}_{3}^{-} \text {but catalyzed by } \mathrm{Cl}^{-} \\
\text {Unaffected by the dielectric constant in aqueous } \\
\text { ethylene glycol or sucrose solutions } \\
\text { Decreased } 20 \text { to } 40 \% \text { in } \mathrm{D}_{2} \mathrm{O}\end{array}$ & $\begin{array}{r}200 \\
139 \\
75 \\
201\end{array}$ \\
\hline
\end{tabular}


Table 10.8 (Continued)

\begin{tabular}{|c|c|c|c|c|c|}
\hline Agent & $\begin{array}{c}\text { Typical } \\
\text { concentration, } M\end{array}$ & Solution & $\begin{array}{c}\text { Temp., } \\
{ }^{\circ} \mathbf{C}\end{array}$ & Results & Ref. \\
\hline$V(V)$ & $10^{-3}$ & $2 M \mathrm{HNO}_{3}$ & 24 & $\begin{array}{l}\mathrm{k}^{\prime \prime}=0.2\left[\mathrm{H}^{+}\right]^{2.3} \mathrm{M}^{-1} \mathrm{sec}^{-1} \\
\mathrm{E}_{\mathrm{a}}=49 \pm 1.7(11.7 \pm 0.4)\end{array}$ & 202 \\
\hline $\mathrm{XeO}_{3}$ & $4 \times 10^{-3}$ & $2 \mathrm{M}(\mathrm{H}, \mathrm{Li}) \mathrm{ClO}_{4}$ & 60 & $\begin{array}{l}-\mathrm{d}[\mathrm{Np}(\mathrm{V})] / \mathrm{dt}=\mathrm{k}\left[\mathrm{XeO}_{3}\right][\mathrm{Np}(\mathrm{V})]^{0}\left[\mathrm{H}^{+}\right]^{0} \\
\text { Photochemical reaction, } \mathrm{k}=6.3 \times 10^{-6} \mathrm{sec}^{-1} \\
\text { in strong light from a W source }\end{array}$ & 203 \\
\hline
\end{tabular}

Table 10.9

OXIDATION OF NEPTUNIUM(VI)

\begin{tabular}{|c|c|c|c|c|c|}
\hline Agent & $\begin{array}{l}\text { Typical } \\
\text { concentration, } M\end{array}$ & Solution & $\underset{{ }^{\circ} \mathrm{C}}{\text { Temp. }}$ & Results & Ref. \\
\hline $\mathrm{BrO}^{-}$ & 0.1 & $6.5 M \mathrm{NaOH}$ & 70 & $\begin{array}{l}\mathrm{k}=5.7 \times 10^{-4} \sec ^{-1} ; \text { first order in } \mathrm{Np}(\mathrm{VI}) \\
\quad \text { other dependences: }\left[\mathrm{BrO}^{-}\right]^{0.6},[\mathrm{NaOH}]^{1.6} \\
\mathrm{E}_{\mathrm{a}}=88 \pm 4(21 \pm 1) \\
\text { Catalyzed by } \mathrm{Cu}(\mathrm{II}), \mathrm{Ni}(\mathrm{II}), \mathrm{Co}(\mathrm{II})\end{array}$ & 204 \\
\hline $\mathrm{Fe}(\mathrm{CN})_{6}^{3-}$ & $1.5 \times 10^{-5}$ & $3.2 M \mathrm{KOH}$ & 23 & $\begin{array}{l}\text { Equilibrium established in } 2 \text { to } 3 \mathrm{~min} \\
\{[\mathrm{~Np}(\mathrm{VII})][\mathrm{Fe}(\mathrm{II})]\} /\left\{[\mathrm{Np}(\mathrm{VI})][\mathrm{Fe}(\mathrm{III})]\left[\mathrm{OH}^{-}\right]^{3}\right\}=0.061 \mathrm{M}^{-3}\end{array}$ & 205 \\
\hline $\mathrm{Mn}(\mathrm{VII})$ & $2.5 \times 10^{-4}$ & $1 M \mathrm{NaOH}$ & Room & $\begin{array}{l}\text { Rapid; reaction complete in several seconds with } \\
\text { equimolar concentrations }\end{array}$ & 72 \\
\hline $\mathrm{Pu}(\mathrm{V} 11)$ & $2.4 \times 10^{-4}$ & $1 M \mathrm{NaOH}$ & Room & $\mathrm{k}^{\prime \prime}=2 \times 10^{3} M^{-1} \mathrm{sec}^{-1}$, if first order in each reactant & 72 \\
\hline $\mathrm{S}_{2} \mathrm{O}_{8}^{2-}$ & 0.10 & $0.7 M \mathrm{NaOH}$ & 60 & $\begin{array}{l}-\mathrm{d}[\mathrm{Np}(\mathrm{VI})] / \mathrm{dt}=3.7 \times 10^{-6}\left[\mathrm{~S}_{2} \mathrm{O}_{8}^{2-}\right][\mathrm{Np}(\mathrm{VI})]^{0} M \mathrm{sec}^{-1} \\
\mathrm{E}_{\mathrm{a}}=140 \pm 4(33.5 \pm 1)\end{array}$ & 206 \\
\hline $\mathrm{O}_{3}$ & $\begin{array}{l}0.1 \% \\
\quad \text { (gas vol.) }\end{array}$ & $1 M \mathrm{KOH}$ & 20 & $\begin{array}{l}\mathrm{t}_{1 / 2}=55 \pm 5 \mathrm{sec} ; \text { first order in } \mathrm{Np}(\mathrm{VI}) \\
\text { other dependences: }\left[\mathrm{O}_{3}\right]^{0.5},[\mathrm{KOH}]^{0.5}\end{array}$ & 207 \\
\hline
\end{tabular}


Table 10.10

REDUCTION OF NEPTUNIUM(IV)

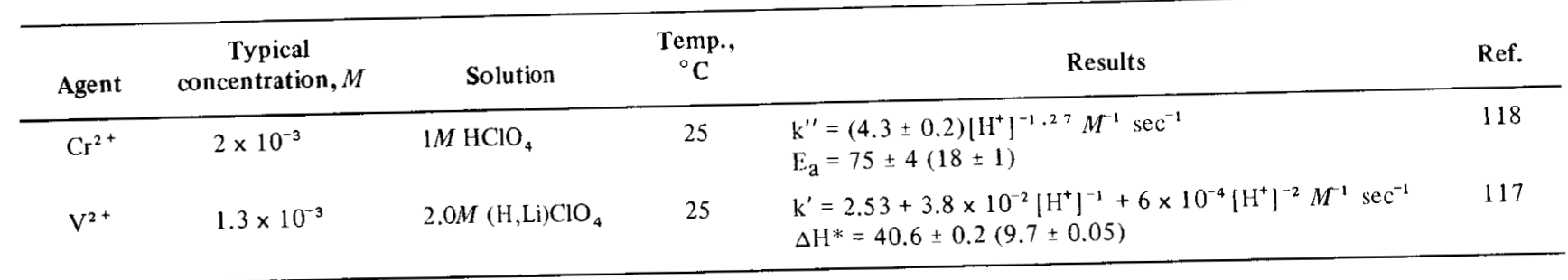

Table 10.11

REDUCTION OF NEPTUNIUM(V)

\begin{tabular}{|c|c|c|c|c|c|}
\hline Agent & $\begin{array}{c}\text { Typical } \\
\text { concentration, } M\end{array}$ & Solution & $\begin{array}{c}\text { Temp., } \\
{ }^{\circ} \mathrm{C}\end{array}$ & Results & Ref. \\
\hline $\mathrm{Cr}(\mathrm{II})$ & $5 \times 10^{-4}$ & $0.21 \mathrm{M}(\mathrm{H}, \mathrm{Li}) \mathrm{ClO}_{4}$ & 25 & $\begin{array}{l}\mathrm{k}^{\prime \prime}=1.15 \times 10^{3}\left[\mathrm{H}^{+}\right] \exp \left(-1.14\left[\mathrm{H}^{+}\right]\right) M^{-1} \mathrm{sec}^{-1} \\
\Delta \mathrm{H}^{*}=7.7 \pm 1(1.85 \pm 0.23) \\
\text { Or k" }=\left(14.2+860\left[\mathrm{H}^{+}\right]\right) M^{-1} \sec ^{-1} \\
\Delta \mathrm{H}^{*}=32 \pm 16(7.6 \pm 3.8) \text { and } \\
\quad 7.9 \pm 2.9(1.9 \pm 0.7) \text { for the respective rate constants } \dagger\end{array}$ & 63 \\
\hline $\mathrm{Fe}(\mathrm{II})$ & $4 \times 10^{-3}$ & $1 M(\mathrm{H}, \mathrm{Na}) \mathrm{ClO}_{4}$ & 25 & $\begin{array}{l}\mathrm{k}^{\prime \prime}=0.078\left[\mathrm{H}^{+}\right] M^{-1} \mathrm{sec}^{-1} \\
\text { Also studied in aqueous solutions of } \mathrm{CH}_{3} \mathrm{OH} \text { and } \mathrm{C}_{2} \mathrm{H}_{5} \mathrm{OH}\end{array}$ & $\begin{array}{l}121 \\
194\end{array}$ \\
\hline $\mathrm{H}_{2} \mathrm{C}_{2} \mathrm{O}_{4}$ & 0.17 & $2 \mathrm{M}(\mathrm{H}, \mathrm{Na}) \mathrm{ClO}_{4}$ & 68 & $\begin{array}{l}\{\mathrm{d}[\mathrm{Np}(\mathrm{IV})] / \mathrm{dt}\}_{0}=\left[\mathrm{NpO}_{2}^{+}\right]\left[\mathrm{C}_{2} \mathrm{O}_{4}^{2-}\right]\left[\mathrm{H}^{+}\right]\left(\mathrm{k}_{1}+\mathrm{k}_{2}\left[\mathrm{NpO}_{2}^{+}\right]\left[\mathrm{C}_{2} \mathrm{O}_{4}^{2-}\right]\left[\mathrm{H}^{+}\right]\right. \\
\left.\quad+\mathrm{k}_{3}\left[\mathrm{NpO}_{2}^{+}\right]\left[\mathrm{C}_{2} \mathrm{O}_{4}^{2-}\right]\right) \\
\mathrm{k}_{1}=32 \mathrm{M}^{-2} \sec ^{-1}, \mathrm{k}_{2}=5.3 \times 10^{10} \mathrm{M}^{-5} \mathrm{sec}^{-1}, \mathrm{k}_{3}=7 \times 10^{12} \mathrm{M}^{-4} \mathrm{sec}^{-1} \\
\text { The association quotients for } \mathrm{NpO}_{2} \mathrm{C}_{2} \mathrm{O}_{4}^{-} \text {and } \mathrm{NpO}_{2}\left(\mathrm{C}_{2} \mathrm{O}_{4}\right)_{2}^{3-} \text { were } \\
\text { taken as } 3 \times 10^{-3} M^{-1} \text { and } 1 \times 10^{-6} M^{-2} \text {, respectively. The acid } \\
\text { dissociation quotients for } \mathrm{H}_{2} \mathrm{C}_{2} \mathrm{O}_{4} \text { were taken as } 6.3 \times 10^{-2} \mathrm{M} \text { and } \\
1.7 \times 10^{-4} \mathrm{M} \text {, respectively } \\
\text { Also studied in }\left(\mathrm{NH}_{4}\right)_{2} \mathrm{C}_{2} \mathrm{O}_{4} \text { solutions } \\
\text { (Table continues on follo }\end{array}$ & $\begin{array}{r}209 \\
\text { page. }\end{array}$ \\
\hline
\end{tabular}


Table 10.11 (Continued)

\begin{tabular}{|c|c|c|c|c|c|}
\hline Agent & $\begin{array}{c}\text { Typical } \\
\text { concentration, } M\end{array}$ & Solution & $\begin{array}{l}\text { Temp., } \\
{ }^{\circ} \mathbf{C}\end{array}$ & Results & Ref. \\
\hline $\mathrm{H}_{2} \mathrm{O}_{2}$ & & $\begin{array}{l}0.5 \mathrm{M} \mathrm{HNO}_{3} \\
7.5 \mathrm{M} \mathrm{HNO}_{3}\end{array}$ & $\begin{array}{l}\text { Room } \\
20\end{array}$ & $\begin{array}{l}\text { No reaction detectable in } 24 \mathrm{hr} \\
\mathrm{k}^{\prime \prime}=9.3 \mathrm{M}^{-1} \mathrm{~min}^{-1} \\
\mathrm{E}_{\mathrm{a}}=55 \pm 2(13.2 \pm 0.5)\end{array}$ & $\begin{array}{l}157 \\
210\end{array}$ \\
\hline $\mathrm{I}^{-}$ & $10^{-2}$ & $3.3 \mathrm{M} \mathrm{HCl}$ & 25 & $\begin{array}{l}\mathrm{k}^{\prime \prime}=0.103[\mathrm{~Np}(\mathrm{~V})]^{-0.14}\left[\mathrm{I}^{-0.55}\left[\mathrm{H}^{+}\right]^{2.61} M^{-1} \mathrm{~min}^{-1}\right. \\
\mathrm{E}_{\mathrm{a}}=118(28.3) \\
\text { Or k" }=\left(1.82 \times 10^{-2}\left[\mathrm{H}^{+}\right]^{2}+0.54\left[\mathrm{I}^{-}\right]\left[\mathrm{H}^{+}\right]^{3}\right) M^{-1} \mathrm{~min}^{-1}\end{array}$ & 211 \\
\hline $\mathrm{NH}_{3} \mathrm{OH}^{+}$ & & $M$ acid & Room & Very slow & 157 \\
\hline $\mathrm{N}_{2} \mathrm{H}_{5}^{+}$ & & $\begin{array}{l}1 \mathrm{M} \text { acid } \\
\mathrm{HNO}_{3} \text { (conc.) }\end{array}$ & Room & $\begin{array}{l}\text { Very slow } \\
\text { Rapid }\end{array}$ & $\begin{array}{l}157 \\
212\end{array}$ \\
\hline $\mathrm{N}_{2} \mathrm{H}_{s}^{+}$ & 0.5 & $5 M(\mathrm{H}, \mathrm{Na}) \mathrm{ClO}_{4}$ & 92 & $\begin{array}{l}\mathrm{k}^{\prime \prime}=(9.7 \pm 0.6) \times 10^{-6} \mathrm{M}^{-1} \mathrm{sec}^{-1} \\
\mathrm{E}_{\mathrm{a}}=103 \pm 2(24.5 \pm 0.5) \\
\text { A parallel path which involves the disproportionation of } \\
\mathrm{Np}(\mathrm{V}) \text { is also important }\end{array}$ & 215 \\
\hline$N p(I I I)$ & & & & (See Table 10.6) & \\
\hline $\operatorname{Sn}(I I)$ & & $\mathrm{HCl}$ & Room & Very slow & 157 \\
\hline $\begin{array}{l}\mathrm{SO}_{2} \\
\mathrm{U}(\mathrm{IV})\end{array}$ & & $\mathrm{H}_{2} \mathrm{SO}_{4}$ & Room & $\begin{array}{l}\text { Very slow, catalyzed by } \mathrm{F}^{-} \\
\text {(See Table } 10.2 \text { ) }\end{array}$ & 157 \\
\hline $\mathrm{V}(\mathrm{III})$ & $1.5 \times 10^{-3}$ & $3 \mathrm{M}(\mathrm{H}, \mathrm{Li}) \mathrm{ClO}_{4}$ & 25 & $\begin{array}{l}\mathrm{k}^{\prime \prime}=\left(0.30+0.16[\mathrm{~Np}(\mathrm{IV})][\mathrm{V}(\mathrm{IV})]^{-1}\left[\mathrm{H}^{+}\right]^{-1.5}\right) \mathrm{M}^{-1} \mathrm{sec}^{-1} \\
\Delta \mathrm{H}^{*}=61 \pm 3(14.6 \pm 0.8) \text { for first rate constant }\end{array}$ & 48 \\
\hline
\end{tabular}

†Original data recalculated. 
Table 10.12

REDUCTION OF NEPTUNIUM(VI)

\begin{tabular}{|c|c|c|c|c|c|}
\hline Agent & $\begin{array}{l}\text { Typical } \\
\text { concentration, } M\end{array}$ & Solution & $\begin{array}{l}\text { Temp., } \\
{ }^{\circ} \mathrm{C}\end{array}$ & Results & Ref. \\
\hline $\mathrm{Cl}^{-}$ & 1.0 & $1 M \mathrm{HCl}$ & Room & Very slow, catalyzed by Pt or Au & 157 \\
\hline EDTA & $5 \times 10^{-3}$ & $1 M(\mathrm{H}, \mathrm{Na}) \mathrm{ClO}_{4}$ & 25 & $\begin{array}{l}\mathrm{k}^{\prime \prime}=0.1\left[\mathrm{H}^{+}\right]^{-1.5} M^{-1} \sec ^{-1} \\
\mathrm{E}_{\mathrm{a}}=97.5 \pm 0.4(23.3 \pm 0.1)\end{array}$ & 213 \\
\hline Fe(II) & $10^{-4}$ & $1 M \mathrm{HClO}_{4}$ & 1 & $\mathrm{k}^{\prime \prime} \approx 3 \times 10^{3} \mathrm{M}^{-1} \sec ^{-1}$ (preliminary observation) & \\
\hline $\mathrm{H}_{2} \mathrm{C}_{2} \mathrm{O}_{4}$ & $2 \times 10^{-2}$ & $1 M(\mathrm{H}, \mathrm{Na}) \mathrm{ClO}_{4}$ & 25 & $\begin{array}{l}\mathrm{k}^{\prime \prime}=0.012\left[\mathrm{H}^{+}\right]^{-1} M^{-1} \mathrm{sec}^{-1} \\
\mathrm{E}_{\mathrm{a}}=54 \pm 4(13 \pm 1) \dagger \\
\text { Net reaction is reported to be } 4 \mathrm{NpO}_{2}^{2+}+\mathrm{H}_{2} \mathrm{C}_{2} \mathrm{O}_{4}+ \\
\quad \mathrm{H}_{2} \mathrm{O}=4 \mathrm{NpO}_{2}^{+}+2 \mathrm{CO}_{2}+1 / 2 \mathrm{O}_{2}+4 \mathrm{H}^{+}\end{array}$ & 214 \\
\hline $\mathrm{HNO}_{2}$ & & $1 M \mathrm{HNO}_{3}$ & Room & Very rapid & 157 \\
\hline $\mathrm{H}_{2} \mathrm{O}_{2}$ & & $3 \mathrm{M}(\mathrm{H}, \mathrm{Na}) \mathrm{ClO}_{4}$ & 25 & $\begin{array}{l}\mathrm{k}^{\prime \prime}=8.9\left[\mathrm{H}^{+}\right]^{-1} /\{1+1.9[\mathrm{~Np}(\mathrm{~V})] /[\mathrm{Np}(\mathrm{IV})]\} M^{-1} \mathrm{sec}^{-1} \\
\mathrm{E}_{\mathrm{a}}=52 \pm 4.6(12.4 \pm 1.1) \text { for first rate constant }\end{array}$ & 58 \\
\hline$p$-hydroquinone & $10^{-3}$ & $1 M(\mathrm{H}, \mathrm{Li}) \mathrm{ClO}_{4}$ & 25 & $\begin{array}{l}\mathrm{k}^{\prime \prime}=4.5 \times 10^{4}\left[\mathrm{H}^{+}\right]^{0}[\mathrm{~Np}(\mathrm{~V})]^{0} M^{-1} \sec ^{-1} \\
\Delta \mathrm{H}^{*}=34.2 \pm 1.4(8.17 \pm 0.34) \\
\text { Reaction with } p \text {-toluhydroquinone is very similar; } \mathrm{k}^{\prime \prime} \text { is } \\
\quad \text { about } 40 \% \text { greater and } \Delta \mathrm{H}^{*}=38.4 \pm 1.2(9.2 \pm 0.3)\end{array}$ & 145 \\
\hline $\mathrm{NH}_{3} \mathrm{OH}^{+}$ & & $1 M$ acid & Room & Very rapid & 145 \\
\hline $\mathrm{N}_{2} \mathrm{H}_{5}^{+}$ & 0.03 & $2 \mathrm{M}(\mathrm{H}, \mathrm{Na}) \mathrm{ClO}_{4}$ & 25 & $\begin{array}{l}\mathrm{k}^{\prime \prime}=\left(11.8\left[\mathrm{H}^{+}\right]^{-1}+5.3\left[\mathrm{H}^{+}\right]^{-2}\right) 10^{-2} M^{-1} \mathrm{sec}^{-1} \\
\Delta \mathrm{H}^{*}=66 \pm 3(15.9 \pm 0.8) \text { and } 58 \pm 9(13.9 \pm 2.3) \\
\text { for the respective rate constants }\end{array}$ & 135 \\
\hline $\mathrm{Np}($ III $)$ & & & & (See Table 10.6) & \\
\hline$N p(I V)$ & & & & (See Table 10.7) & \\
\hline $\mathrm{Pu}(\mathrm{III})$ & & & & (See Table 10.14) & \\
\hline
\end{tabular}


Table 10.12 (Continued)

\begin{tabular}{|c|c|c|c|c|c|}
\hline Agent & $\begin{array}{c}\text { Typical } \\
\text { concentration, } M\end{array}$ & Solution & $\underset{\text { Temp., }}{\stackrel{\circ}{ } \mathrm{C}}$ & Results & Ref. \\
\hline $\mathrm{Pu}(\mathrm{V})$ & $10^{-4}$ & $1 M \mathrm{HClO}_{4}$ & 2 & $\mathrm{k}^{\prime \prime} \approx 5 \times 10^{3} M^{-1} \sec ^{-1}$ (preliminary observation) & \\
\hline $\operatorname{Sn}(I I)$ & & $\mathrm{HCl}$ & Room & Very rapid & 157 \\
\hline U(IV) & & & & (See Table 10.2) & \\
\hline V(III) & $10^{-3}$ & $2 \mathrm{M}(\mathrm{H}, \mathrm{Na}) \mathrm{ClO}_{4}$ & 25 & $\begin{array}{l}\mathrm{k}^{\prime \prime}=5.7+22.6\left[\mathrm{H}^{+}\right]^{-1} M^{-1} \sec ^{-1} \\
\Delta \mathrm{H}^{*}=134 \pm 21(32 \pm 5) \text { and }\end{array}$ & 132 \\
\hline & & & & $54 \pm 8(13 \pm 2)$ for the respective rate constants $\dagger$ & \\
\hline $\mathrm{V}(\mathrm{IV})$ & $10^{-3}$ & $2 \mathrm{M} \mathrm{HClO}_{4}$ & 25 & $\mathrm{k}^{\prime \prime}=13 \mathrm{M}^{\mathrm{l}} \mathrm{sec}^{-1}$ (preliminary result) & 132 \\
\hline
\end{tabular}

$\dagger$ Original data recalculated.

Table 10.13

REDUCTION OF NEPTUNIUM(VII)

\begin{tabular}{|c|c|c|c|c|c|}
\hline Agent & $\begin{array}{c}\text { Typical } \\
\text { concentration, } M\end{array}$ & Solution & $\underset{{ }^{\circ} \mathrm{C}}{\text { Temp. }}$ & Results & Ref. \\
\hline $\operatorname{Ag}(\mathrm{I})$ & 0.02 & $1 M \mathrm{HClO}_{4}$ & 25 & $\begin{array}{l}\mathrm{k}^{\prime \prime}=(3.54 \pm 0.05) \times 10^{3}\left[\mathrm{H}^{+}\right] M^{-1} \mathrm{sec}^{-1} \\
\Delta \mathrm{H}^{*}=3.4 \pm 0.3(0.81 \pm 0.08)\end{array}$ & 216 \\
\hline $\mathrm{C}_{2} \mathrm{O}_{4}^{2-}$ & 0.2 & $0.1 M \mathrm{NaOH}$ & 65 & $t_{1 / 2}=1900 \sec \left(>6000 \sec\right.$ at $25^{\circ} \mathrm{C}$ or in $\left.2 M \mathrm{NaOH}\right)$ & 217 \\
\hline $\mathrm{C}_{2} \mathrm{H}_{5} \mathrm{OH}$ & 1.5 & $0.1 M \mathrm{NaOH}$ & 65 & $t_{1 / 2}=300 \sec (1800 \mathrm{sec}$ in $2 M \mathrm{NaOH})$ & 217 \\
\hline Citrate & 0.09 & $0.1 M \mathrm{NaOH}$ & 25 & $t_{1 / 2}=720 \mathrm{sec}$ & 217 \\
\hline $\operatorname{Co}(\mathrm{II})$ & $1.5 \times 10^{-3}$ & $1 M(\mathrm{H}, \mathrm{Li}) \mathrm{ClO}_{4}$ & 25 & $\begin{array}{l}\mathrm{k}^{\prime \prime}=\mathrm{k}_{1}\left(\mathrm{H}^{+}\right]\left(1+\mathrm{k}_{1}\left[\mathrm{H}^{+}\right] / \mathrm{k}_{2}\right)^{-1} \\
\mathrm{k}_{1}=9.51 \times 10^{4} M^{-2} \mathrm{sec}^{-1} \\
\mathrm{k}_{2}=5.85 \times 10^{4} M^{-1} \mathrm{sec}^{-1}\end{array}$ & 216 \\
\hline
\end{tabular}




\begin{tabular}{|c|c|c|c|c|c|}
\hline & & & & $\begin{array}{l}\Delta \mathrm{H}_{1}^{*}=-15 \pm 2(-3.6 \pm 0.5) \\
\Delta \mathrm{H}_{2}^{*}=40 \pm 2(9.65 \pm 0.5)\end{array}$ & \\
\hline EDTA & 0.01 & $0.1 M \mathrm{NaOH}$ & 25 & $t_{1 / 2}=4500 \sec \left(66 \sec\right.$ at $65^{\circ} \mathrm{C}, 2700 \sec$ in $\left.2 M \mathrm{NaOH}\right)$ & 217 \\
\hline $\mathrm{HCHO}$ & 0.06 & $0.1 M \mathrm{NaOH}$ & 25 & $t_{1 / 2}=90 \mathrm{sec}$ & 217 \\
\hline $\mathrm{HCO}_{2}^{-}$ & 0.09 & $0.1 M \mathrm{NaOH}$ & 25 & $t_{1 / 2}=300 \mathrm{sec}$ & 217 \\
\hline $\mathrm{HCOOH}$ & 0.02 & $1 M(\mathrm{H}, \mathrm{Li}) \mathrm{ClO}_{4}$ & 25 & $\begin{array}{l}\mathrm{k}^{\prime \prime}=0.402+0.0538\left[\mathrm{H}^{+}\right]^{-1} M^{-1} \mathrm{sec}^{-1} \\
\mathrm{E}_{\mathrm{a}}=27 \pm 1(6.4 \pm 0.3) \text { and } 44 \pm 1(10.5 \pm 0.2) \\
\text { for the respective rate constants } \\
\text { Deuterium isotope effect determined }\end{array}$ & 137 \\
\hline $\mathrm{H}_{2} \mathrm{O}$ & 55.5 & $3 M(\mathrm{H}, \mathrm{Li}) \mathrm{ClO}_{4}$ & 25 & $\mathrm{k}=7.64 \times 10^{-4}\left[\mathrm{H}^{+}\right]^{1.15}+4.41[\mathrm{~Np}(\mathrm{VII})]\left[\mathrm{H}^{+}\right]^{0.15} \mathrm{sec}^{-1}$ & 24 \\
\hline $\mathrm{H}_{2} \mathrm{O}$ & 55.5 & $\begin{array}{l}1 M(\mathrm{H}, \mathrm{Na}) \mathrm{NO}_{3} \\
1 M(\mathrm{H}, \mathrm{Na}) \mathrm{ClO}_{4}\end{array}$ & 40 & $\begin{array}{l}\mathrm{k}=10^{-3}\left(0.5+1.7\left[\mathrm{H}^{+}\right]\right) \mathrm{sec}^{-1} \\
\mathrm{E}_{\mathrm{a}}=66 \pm 4(15.8 \pm 1) \text { in } 1 M \mathrm{HNO}_{3} \\
\mathrm{k}=10^{-3}\left(0.87+2.38\left[\mathrm{H}^{+}\right]\right) \mathrm{sec}^{-1}\end{array}$ & 53 \\
\hline $\mathrm{Hg}(\mathrm{I})$ & $10^{-3}$ & $1 M(\mathrm{H}, \mathrm{Li}) \mathrm{ClO}_{4}$ & 25 & $\begin{array}{l}\mathrm{k}^{\prime \prime}=28.1+13.4\left[\mathrm{H}^{+}\right] M^{-1} \sec ^{-1} \\
\mathrm{E}_{\mathrm{a}}=51 \pm 13(12.3 \pm 3) \text { and } 35 \pm 3(8.3 \pm 0.8) \\
\text { for the respective rate constants }\end{array}$ & 55 \\
\hline $\mathrm{I}^{-}$ & 0.14 & $\begin{array}{l}0.0155 \mathrm{M} \mathrm{NaOH} \\
0.6 M \mathrm{NaNO}_{3}\end{array}$ & 25 & $\begin{array}{l}\text { Reaction is autocatalytic and is half complete } \\
\text { in } 420 \mathrm{sec} ; \mathrm{I}_{3}^{-} \text {is apparently the reactive species }\end{array}$ & 217 \\
\hline $\mathrm{NO}_{2}^{-}$ & 0.07 & $0.1 M \mathrm{NaOH}$ & 65 & $\mathrm{t}_{1 / 2} \approx 6000 \mathrm{sec}\left(\mathrm{NH}_{3}\right.$ and $\mathrm{CH}_{3} \mathrm{O}_{2}^{-}$are also reduced slowly) & 217 \\
\hline $\mathrm{SO}_{3}^{2-}$ & 0.07 & $0.7 M \mathrm{Na}\left(\mathrm{OH}, \mathrm{NO}_{3}\right)$ & 25 & $\begin{array}{l}\mathrm{k}^{\prime \prime}=10^{-3}\left(1.5\left[\mathrm{OH}^{-}\right]+0.67\left[\left.\mathrm{OH}^{-}\right|^{2}\right) M^{-1} \mathrm{sec}^{-1}\right. \\
\mathrm{E}_{\mathrm{a}}=92 \pm 8(22 \pm 2) \text { for }\left[\mathrm{OH}^{-}\right]=0.5 M \\
\text { Reaction is catalyzed by } \mathrm{Cu}(\mathrm{II}), \mathrm{Co}(\mathrm{II}), \mathrm{Mn}(\mathrm{VII}) \\
\mathrm{Fe}(\mathrm{III}), \text { and } \mathrm{Np}(\mathrm{VI})\end{array}$ & 217 \\
\hline $\mathrm{S}_{2} \mathrm{O}_{3}^{2-}$ & 0.05 & $0.1 M \mathrm{NaOH}$ & 25 & $t_{1 / 2}=3900 \mathrm{sec}$ & 217 \\
\hline $\operatorname{Tl}(\mathbf{I})$ & $5 \times 10^{-3}$ & $1 M(\mathrm{H}, \mathrm{Li}) \mathrm{ClO}_{4}$ & 25 & $\begin{array}{l}\mathrm{k}^{\prime \prime}=4.46\left[\mathrm{H}^{+}\right]^{0.9} M^{-1} \sec ^{-1} \\
\mathrm{E}_{\mathrm{a}}=32 \pm 2(7.7 \pm 0.4)\end{array}$ & 54 \\
\hline$V(I V)$ & 0.023 & $1 M(\mathrm{H}, \mathrm{Li}) \mathrm{ClO}_{4}$ & 25 & $\begin{array}{l}\mathrm{k}^{\prime \prime}=1.44 \times 10^{3}\left[\mathrm{H}^{+}\right]^{-0.1} M^{-1} \mathrm{sec}^{-1} \\
\mathrm{E}_{\mathrm{a}}=31 \pm 4(7.3 \pm 0.9)\end{array}$ & 138 \\
\hline
\end{tabular}


Table 10.14

OXIDATION OF PLUTONIUM(III)

\begin{tabular}{|c|c|c|c|c|c|}
\hline Agent & $\begin{array}{l}\text { Typical } \\
\text { concentration, } M\end{array}$ & Solution & $\underset{{ }^{\circ} \mathrm{C}}{\text { Temp., }}$ & Results & Ref. \\
\hline $\mathrm{BrO}_{3}^{-}$ & 0.016 & $0.84 \mathrm{M} \mathrm{HClO}_{4}$ & 25 & $\begin{array}{l}\text { Autocatalytic; reaction complete in } 130 \mathrm{sec} \\
\text { (preliminary result) }\end{array}$ & 218 \\
\hline $\mathrm{Ce}(\mathrm{IV})$ & $3 \times 10^{-3}$ & $0.5 M \mathrm{HCl}$ & Room & $\mathrm{t}_{1 / 2} \leqslant 5 \mathrm{sec}$ & 158 \\
\hline $\mathrm{Cl}_{2}$ & 0.025 & $1.5 \mathrm{M} \mathrm{HCl}$ & Room & $\begin{array}{l}\mathrm{k}=7 \times 10^{-6} \mathrm{sec}^{-1} \\
{[\mathrm{Cl} / \mathrm{dependence} \mathrm{not} \mathrm{clear,} \mathrm{rate} \mathrm{increases} \mathrm{with}} \\
{[\mathrm{HCl}]} \\
\text { Reaction is catalyzed by } \mathrm{Cu}(\mathrm{II}) \text { and } \mathrm{Fe}(\mathrm{III}) \\
\text { Reaction also studied in sulfate solutions }\end{array}$ & $\begin{array}{l}219 b \\
219 c\end{array}$ \\
\hline $\mathrm{Cr}(\mathrm{III}) \cdot \mathrm{Pu}(\mathrm{V})$ & $10^{-4}$ & $2 M(\mathrm{H}, \mathrm{Li}) \mathrm{ClO}_{4}$ & 25 & $\begin{array}{l}\mathrm{k}^{\prime \prime}=122\left[\mathrm{H}^{+}\right]^{0} M^{-1} \mathrm{sec}^{-1} \\
\Delta \mathrm{H}^{*}=19.2 \pm 0.4(4.6 \pm 0.1)\end{array}$ & 80 \\
\hline $\mathrm{Cr}(\mathrm{VI})$ & $1.5 \times 10^{-5}$ & $2 \mathrm{M}(\mathrm{H}, \mathrm{Li}) \mathrm{ClO}_{4}$ & 25 & $\begin{array}{l}\mathrm{k}^{\prime \prime}=2.4 \times 10^{4}\left[\mathrm{H}^{+}\right]^{2} M^{-1} \mathrm{sec}^{-1} \\
\text { Inhibited by Pu(IV) }\end{array}$ & 218 \\
\hline $\mathrm{H}_{2} \mathrm{O}_{2}$ & 0.3 & $1 M \mathrm{H}_{2} \mathrm{SO}_{4}$ & Room & Essentially comple te in 1 to $2 \mathrm{~min}$; slower in $\mathrm{HCl}$ & 158 \\
\hline $\mathrm{IO}_{3}^{-}$ & 0.0156 & $1 M \mathrm{HClO}_{4}$ & 25 & $\mathrm{k} \approx 10^{-6} \sec ^{-1}$ (preliminary result) & 218 \\
\hline $\mathrm{MnO}_{4}^{-}$ & & Dilute acid & Room & Extremely rapid & 158 \\
\hline $\mathrm{NpO}_{2}^{2+}$ & $3 \times 10^{-3}$ & $\mathrm{I} M(\mathrm{H}, \mathrm{Li}) \mathrm{ClO}_{4}$ & 25 & $\begin{array}{l}\mathrm{k}^{\prime \prime}=35.3+3.1\left[\mathrm{H}^{+}\right]^{-1} M^{1} \mathrm{sec}^{-1} \\
\Delta \mathrm{H}^{*}=14.6 \pm 0.2(3.49 \pm 0.05) \\
\text { for the larger term }\end{array}$ & 77 \\
\hline
\end{tabular}




\begin{tabular}{|c|c|c|c|c|c|}
\hline $\mathrm{NO}_{3}^{-}$ & $0.2\left(\mathrm{NaNO}_{3}\right)$ & $0.5 M \mathrm{HCl}$ & Room & $\begin{array}{l}\mathrm{t}_{1 / 2} \approx 600 \mathrm{hr} ; \text { autocataly tic; rapid in } \\
16 \mathrm{HNO}_{3}\end{array}$ & 158 \\
\hline \multirow[t]{2}{*}{$\mathrm{HNO}_{2}$} & $3 \times 10^{-4}$ & $1 M$ to $2 M \mathrm{HCl}$ & 25 & $\begin{array}{l}-\mathrm{d}[\mathrm{Pu}(\mathrm{III})] / \mathrm{dt}=0.3[\mathrm{Pu}(\mathrm{III})]\left[\mathrm{HNO}_{2}\right]^{0.83} \\
{\left[\mathrm{HCl}^{1.28} \times\left(1+5\left[\mathrm{NO}_{3}^{-}\right]\right) M \mathrm{sec}^{-1}\right.}\end{array}$ & $220 \mathrm{a}$ \\
\hline & & $2 M(\mathrm{H}, \mathrm{Na}) \mathrm{NO}_{3}$ & 25 & $\mathrm{k}=1.55\left[\mathrm{HNO}_{2}\right]^{0.5} \mathrm{~min}^{-1}$ & $220 \mathrm{~b}$ \\
\hline $\mathrm{O}_{2}$ & $\begin{array}{l}\text { Saturated at } \\
0.74 \mathrm{~atm}\end{array}$ & $2 \mathrm{M}(\mathrm{H}, \mathrm{Na}) \mathrm{ClO}_{4}$ & 25 & $\begin{array}{l}\mathrm{k}^{\prime \prime}=[\mathrm{Pu}(\mathrm{III})]\left(5.5\left[\mathrm{SO}_{4}^{2-}\right]^{2}+179\left[\mathrm{SO}_{4}^{2-}\right]^{3} \mathrm{~J} /\right. \\
\left(1+10\left[\mathrm{SO}_{4}^{2-}\right]+50\left[\mathrm{SO}_{4}^{2-}\right]^{2}\right) \mathrm{atm}^{-1} \mathrm{sec}^{-1} \\
\mathrm{E}_{\mathrm{a}} \approx 79(19)\end{array}$ & 221 \\
\hline $\mathrm{Pu}^{4+}$ & $3 \times 10^{-6}$ & $2 M(\mathrm{H}, \mathrm{Li}) \mathrm{ClO}_{4}$ & 25 & $\begin{array}{l}\mathrm{k}^{\prime \prime}=6.4 \times 10^{4}\left[\mathrm{H}^{+}\right]^{-1} M^{-1} \mathrm{sec}^{-1} \\
\mathrm{E}_{\mathrm{a}}=31 \pm 5(7.4 \pm 1)\end{array}$ & 74 \\
\hline $\mathrm{PuO}_{2}^{+}$ & $\begin{array}{l}2 \times 10^{-3} \\
1.5 \times 10^{-3}\end{array}$ & $\begin{array}{l}0.5 \mathrm{M} \mathrm{HCl} \\
1 M \mathrm{HClO}_{4}\end{array}$ & $\begin{array}{l}25 \\
25\end{array}$ & $\begin{array}{l}\mathrm{k}^{\prime \prime}=0.058\left[\mathrm{H}^{+}\right] M^{-1} \mathrm{sec}^{-1} \\
\mathrm{k}^{\prime \prime}=4.44 \times 10^{-2} M^{-1} \sec ^{-1} \\
\Delta \mathrm{H}^{*}=33 \pm 1(8.0 \pm 0.3)\end{array}$ & $\begin{array}{r}222 \\
80\end{array}$ \\
\hline \multirow[t]{2}{*}{$\mathrm{PuO}_{2}^{2+}$} & $10^{-4}$ & $1 M \mathrm{HClO}_{4}$ & 25 & $\begin{array}{l}\mathrm{k}^{\prime \prime}=2.68\left[\mathrm{H}^{+}\right]^{0} M^{-1} \mathrm{sec}^{-1} \\
\Delta \mathrm{H}^{*}=20.2 \pm 0.4(4.8 \pm 0.1)\end{array}$ & 78 \\
\hline & & & & $\begin{array}{l}\text { The reaction has also been studied in anhydrous } \\
\text { acetic acid }\end{array}$ & 223 \\
\hline $\mathrm{Tl}^{3+}$ & & $\begin{array}{l}\text { Dilute } \\
\mathrm{HClO}_{4}\end{array}$ & Room & Very slow & 158 \\
\hline $\mathrm{XeO}_{3}$ & $10^{-3}$ & $2 \mathrm{M}(\mathrm{H}, \mathrm{Li}) \mathrm{ClO}_{4}$ & 30 & $\mathrm{k}^{\prime \prime}=1.8 \times 10^{-2} M^{-1} \sec ^{-1}$ & 147 \\
\hline
\end{tabular}


Table $\mathbf{1 0 . 1 5}$

OXIDATION OF PLUTONIUM(IV)

\begin{tabular}{|c|c|c|c|c|c|}
\hline Agent & $\begin{array}{l}\text { Typical } \\
\text { concentration, } M\end{array}$ & Solution & $\begin{array}{l}\text { Temp. } \\
{ }^{\circ} \mathrm{C}\end{array}$ & Results & Ref. \\
\hline $\operatorname{Ag}(\mathrm{II})$ & 0.1 & $1.1 \mathrm{M} \mathrm{HNO}_{3}$ & Room & Complete in $<60 \mathrm{sec}$ & 158 \\
\hline $\mathrm{Ag}_{2} \mathrm{O}$ & & $45 \% \mathrm{~K}_{2} \mathrm{CO}_{3}$ & 75 & $>90 \%$ complete in $45 \mathrm{~min}$ & 158 \\
\hline $\begin{array}{l}\mathrm{Bi}(\mathrm{V}) \\
\left(\mathrm{NaBiO}_{3}\right)\end{array}$ & $0.84 \mathrm{~g} /$ liter & $5 \mathrm{MHNO}$ & Room & Complete in $<5 \mathrm{~min}$ & 158 \\
\hline $\mathrm{BrO}_{3}^{-}$ & 0.2 & $0.2 \mathrm{M} \mathrm{HNO}_{3}$ & 95 & $t_{1 / 2} \approx 13 \mathrm{~min} ;$ slower at higher $\left[\mathrm{HNO}_{3}\right]$ or in $\mathrm{H}_{2} \mathrm{SO}_{4}$ & 158 \\
\hline $\mathrm{Br}_{2}$ & Saturated & $1.5 \mathrm{M} \mathrm{HNO}$ & 50 & $t_{1 / 2} \approx 4 \mathrm{hr}$ & 158 \\
\hline $\mathrm{Ce}(\mathrm{IV})$ & $5 \times 10^{-4}$ & $2.5 \mathrm{M}(\mathrm{H}, \mathrm{Na}) \mathrm{ClO}_{4}$ & 28 & $\begin{array}{l}\mathrm{k}^{\prime \prime}=23\left[\mathrm{H}^{+}\right]^{-2} M^{-1} \mathrm{sec}^{-1} \\
\mathrm{E}_{\mathrm{a}}=61 \pm 4(14.6 \pm 1) \\
\text { In } 0.04 M \text { to } 0.2 M \text { sulfate solutions: } \\
\mathrm{k}^{\prime \prime}=10^{-3}\left(165+0.3\left[\mathrm{H}^{+}\right]^{-1}\left[\mathrm{HSO}_{4}^{-}\right]^{-1}\right)\left[\mathrm{HSO}_{4}^{-}\right]^{-2} M^{-1} \sec ^{-1}\end{array}$ & 124 \\
\hline $\mathrm{Cl}_{2}$ & 0.025 & $\begin{array}{l}0.1 \mathrm{M} \mathrm{HClO}_{4} \\
0.056 \mathrm{M} \mathrm{Cl}^{-}\end{array}$ & 22 & $\mathrm{t}_{1 / 2} \approx 2 \mathrm{hr} ; 85$ times slower in $1 M \mathrm{HClO}_{4}$ and extremely slow in $1 M \mathrm{H}_{2} \mathrm{SO}_{4}$ & 158 \\
\hline $\begin{array}{l}\mathrm{Cl}(\mathrm{I}) \\
\left(\mathrm{HOCl}-\mathrm{ClO}^{-}\right)\end{array}$ & 0.1 to 0.2 & $\begin{array}{l}4.5 \text { to } 8.2 \mathrm{pH} \\
45 \% \mathrm{~K}_{2} \mathrm{CO}_{3}\end{array}$ & $\begin{array}{l}80 \\
\text { Room }\end{array}$ & $\begin{array}{l}\text { Complete in } 15 \mathrm{~min} \\
\text { Complete in } 5 \text { to } 10 \mathrm{~min}\end{array}$ & 158 \\
\hline $\begin{array}{l}\text { Co(III) } \\
\text { acetate }\end{array}$ & & & 75 & Complete in $10 \mathrm{~min}$ & 158 \\
\hline $\mathrm{HClO}_{4}$ & 12 & Concentrated & Fuming & Rapid & 158 \\
\hline $\mathrm{HCrO}_{4}^{-}$ & 0.04 & $0.1 M \mathrm{HClO}_{4}$ & 25 & $\begin{array}{l}k^{\prime \prime} \approx 0.29 \mathrm{M}^{\mathrm{t}} \mathrm{sec}^{-1} \\
\text { Slower in } \mathrm{H}_{2} \mathrm{SO}_{4} ; \text { catalyzed by } \mathrm{Co}(\mathrm{II}) \\
\text { Complicated by the formation of } \mathrm{Pu}(\mathrm{IV}) \cdot \mathrm{Cr}(\mathrm{VI}) \\
\text { and } \mathrm{Cr}(\mathrm{III}) \cdot \mathrm{Pu}(\mathrm{V}) \text { complexes }\end{array}$ & $\begin{array}{r}158 \\
32\end{array}$ \\
\hline $\mathrm{H}_{5} \mathrm{IO}_{6}$ & 0.02 & $0.22 \mathrm{M} \mathrm{HNO}_{3}$ & Room & $t_{1 / 2} \approx 100 \mathrm{~min} ;$ rate decreases with increasing acidity & 158 \\
\hline $\mathrm{MnO}_{4}^{-}$ & $2 \times 10^{-4}$ & $3 \mathrm{M}(\mathrm{H}, \mathrm{Na}) \mathrm{ClO}_{4}$ & 25 & $\begin{array}{l}-\mathrm{d}[\mathrm{Pu}(\mathrm{IV})] / \mathrm{dt}=(4070 \pm 210)[\mathrm{Pu}(\mathrm{IV})][\mathrm{Mn}(\mathrm{II})][\mathrm{Mn}(\mathrm{VII})]^{0}\left[\mathrm{H}^{+}\right]^{-2} \mathrm{M} \mathrm{min}^{-1} \\
\Delta \mathrm{H}^{*}=91 \pm 1(21.7 \pm 0.2) \\
\Delta \mathrm{S}^{*}=94 \pm 4(22.5 \pm 1)\end{array}$ & 127 \\
\hline
\end{tabular}




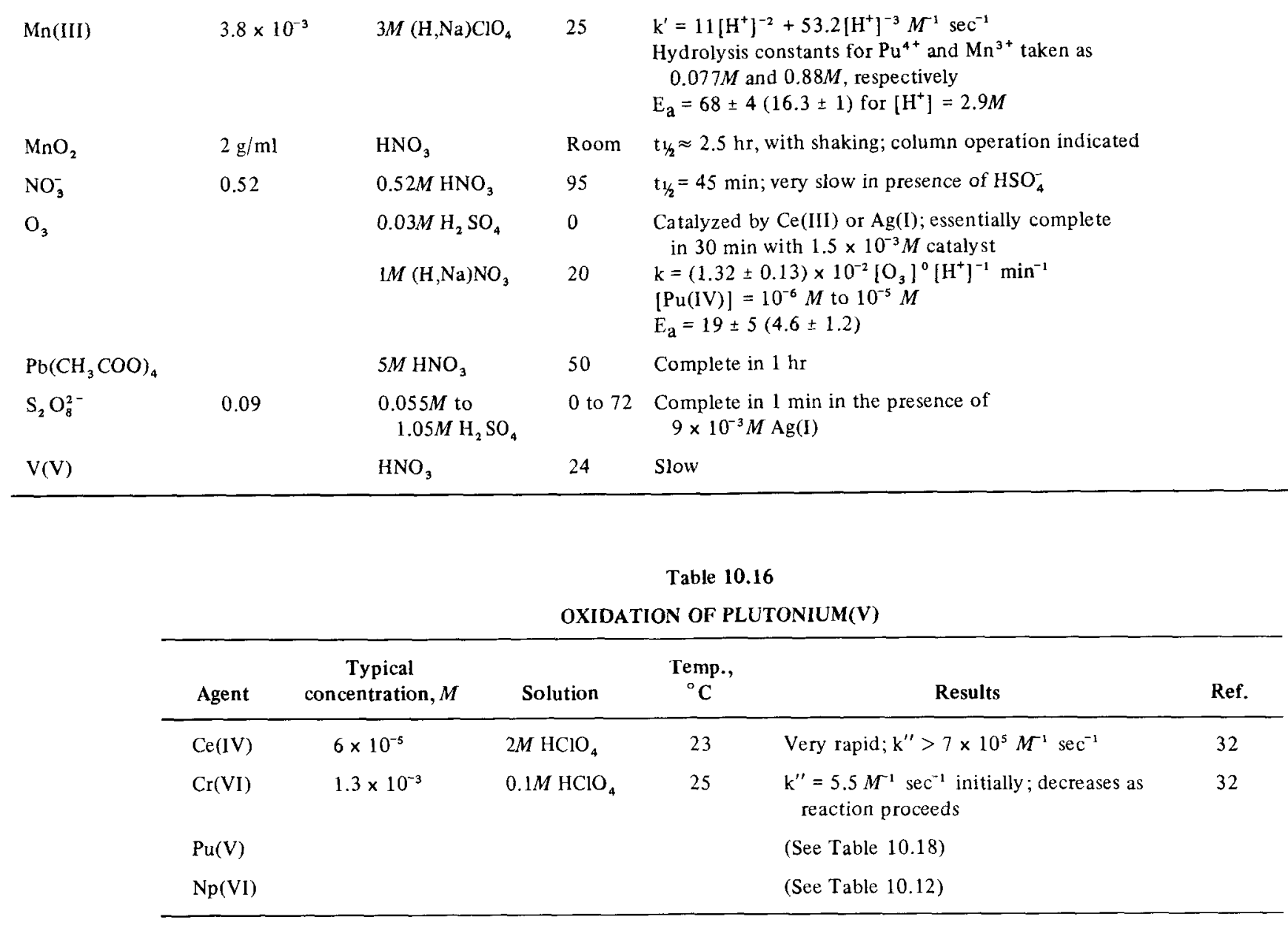


Table 10.17

REDUCTION OF PLUTONIUM(IV)

\begin{tabular}{|c|c|c|c|c|c|}
\hline Agent & $\begin{array}{c}\text { Typical } \\
\text { concentration, } M\end{array}$ & Solution & ${ }^{\circ} \mathrm{C}$ & Results & Ref. \\
\hline $\begin{array}{l}\mathrm{Ag} \\
\text { metal }\end{array}$ & & $2 \mathrm{M} \mathrm{HClO}_{4}$ & 25 & $\begin{array}{l}\text { Rate controlled by diffusion to surface; diffusion } \\
\text { coefficient is } \sim 1.1 \times 10^{-5} \mathrm{~cm}^{2} \mathrm{sec}^{-1} \\
\text { Similar results for } \mathrm{Cu} \text { and } \mathrm{Pb}\end{array}$ & 227 \\
\hline $\begin{array}{l}\text { Ascorbic } \\
\text { acid }\end{array}$ & & 4.7M $\mathrm{HNO}_{3}$ & Room & $\begin{array}{l}\text { Complete in a few minutes in presence of } \mathrm{NH}_{2} \mathrm{SO}_{3} \mathrm{H} \\
\text { to inhibit the ascorbic acid- } \mathrm{HNO}_{3} \text { reaction } \\
\text { Similar results for iso-ascorbic acid }\end{array}$ & 228 \\
\hline $\mathrm{Fe}^{2+}$ & $2 \times 10^{-3}$ & $2 \mathrm{M}(\mathrm{H}, \mathrm{Li}) \mathrm{ClO}_{4}$ & 20 & $\begin{array}{l}\mathrm{k}^{\prime \prime}=27\left[\mathrm{H}^{+}\right]^{-1} M^{-1} \mathrm{sec}^{-1} \\
\mathrm{E}_{\mathrm{a}}=82 \pm 2.5(19.7 \pm 0.6) \\
\text { Rate increased by } \mathrm{Cl}^{-}\end{array}$ & 119 \\
\hline \multirow[t]{2}{*}{$\begin{array}{l}\mathrm{H}_{2} \text { on } \\
\text { platinized } \mathrm{Pt}\end{array}$} & & $2.4 M \mathrm{HCl}$ & Room & $\begin{array}{l}\mathrm{t}_{1 / 2}<5 \mathrm{~min} ;>99 \% \text { reduced in } 45 \mathrm{~min} \\
\text { Rate very low without catalyst }\end{array}$ & 229 \\
\hline & & $\begin{array}{l}0.25 \mathrm{M} \mathrm{H}_{2} \mathrm{SO}_{4} \\
3.5 \mathrm{M} \mathrm{H}_{2} \mathrm{SO}_{4}\end{array}$ & $\begin{array}{l}\text { Room } \\
\text { Room }\end{array}$ & $\begin{array}{l}96 \% \text { complete in } 45 \mathrm{~min} \\
85 \% \text { complete in } 45 \mathrm{~min}\end{array}$ & 230 \\
\hline $\mathrm{H}_{2} \mathrm{O}_{2}$ & $7.9 \times 10^{-4}$ & $0.5 M \mathrm{HCl}$ & 25 & $\begin{array}{l}\mathrm{t}_{1 / 2}=64 \text { min (excess } \mathrm{H}_{2} \mathrm{O}_{2} \text { ) } \\
\text { Complicated by rapid formation of } \mathrm{Pu}(\mathrm{IV})-\mathrm{H}_{2} \mathrm{O}_{2} \\
\text { complexes }\end{array}$ & $\begin{array}{l}158 \\
231\end{array}$ \\
\hline $\begin{array}{l}\mathrm{H}_{2} \mathrm{O}_{2} \text { in } \\
\text { the } \mathrm{PuO}_{2} \mathrm{PuOH}^{5+} \\
\text { complex }\end{array}$ & $2.8 \times 10^{-3}$ & $2 \mathrm{M}(\mathrm{H}, \mathrm{Na}) \mathrm{ClO}_{4}$ & 25 & $\begin{array}{l}\text { Decomposition gives } \mathrm{Pu}(\mathrm{HI}) ; \text { rate is first order } \\
\text { in complex } \\
\mathrm{k}=1.4 \times 10^{-4} \mathrm{sec}^{-1} \\
\mathrm{E}_{\mathrm{a}}=92 \pm 13(22 \pm 3)\end{array}$ & 232 \\
\hline $\mathrm{H}_{2} \mathrm{~S}$ & & Acid & Room & $\mathrm{Pu}(\mathrm{IV})$ "readily reduced" & 158 \\
\hline Hydroquinone & $10^{-5}$ & $1 M(\mathrm{H}, \mathrm{Li}) \mathrm{ClO}_{4}$ & 25 & $\begin{array}{l}\mathrm{k}^{\prime \prime}=1.9 \times 10^{5}\left[\mathrm{H}^{+}\right]^{0} M^{-1} \mathrm{sec}^{-1} \\
\mathrm{E}_{\mathrm{a}}=50 \pm 4(12 \pm 1) \\
\text { Reaction is inhibited by } \mathrm{Pu}(\mathrm{III}) \text { but not by quinone }\end{array}$ & 146 \\
\hline $\mathrm{I}^{-}$ & 0.1 & $0.4 M \mathrm{HCl}$ & Room & $t_{1 / 2} \approx 2 \mathrm{~min} ;$ the $\mathrm{I}^{-}-\mathrm{O}_{2}$ reaction is induced & 158 \\
\hline
\end{tabular}


$2 \times 10^{-3}$

U(IV)

$\mathrm{V}^{3+}$
$1.5 \times 10^{-3}$
$0.5 \mathrm{MHNO}_{3}$

$1.0 \mathrm{M} \mathrm{HNO}_{3}-$ $0.02 \mathrm{M} \mathrm{H}_{2} \mathrm{SO}_{4}$ $1 M \mathrm{HClO}_{4}$

$2 \mathrm{M}(\mathrm{H}, \mathrm{Na}) \mathrm{ClO}_{4}$

$1.0 \mathrm{M}(\mathrm{H}, \mathrm{Na}) \mathrm{ClO}_{4}$

$2.0 \mathrm{M}(\mathrm{H}, \mathrm{Na})\left(\mathrm{ClClO}_{4}\right)$

$0.5 M \mathrm{HCl}$

$1.0 \mathrm{M} \mathrm{HClO}_{4}$

$2.0 \mathrm{M}(\mathrm{H}, \mathrm{Na}) \mathrm{ClO}$
Initial $\mathrm{k}^{\prime \prime}=\left(\mathrm{k}_{1}+\mathrm{k}_{2}\left[\mathrm{NH}_{3} \mathrm{OH}^{+}\right]\right) /\left\{\left[\mathrm{H}^{+}\right]^{2}\left(1+2\left[\mathrm{NO}_{3}^{-} \mid\right)\right\}\right.$

$\mathrm{k}_{\mathrm{t}}=7 \pm 1.1 \mathrm{M} \mathrm{sec}^{-1} ; \mathrm{E}_{\mathrm{a}}=88 \pm 5(21 \pm 1.3)$

$\mathrm{k}_{2}=48 \pm 9 \mathrm{sec}^{-1} ; \mathrm{E}_{\mathrm{a}}=107 \pm 11(25.5 \pm 2.7)$

Rate is inhibited by Pu(III)

Stoichiome try is complicated in that both $\mathrm{N}_{2}$ and $\mathrm{N}_{2} \mathrm{O}$

are products.

Catalyzed by $\mathrm{Fe}(\mathrm{III})$

Room $\quad \mathrm{k}^{\prime \prime}>0.2 \mathrm{M}^{-1} \mathrm{sec}^{-1}$

Room

$\mathrm{t}_{1 / 2}=8.2 \mathrm{~min}($ tracer concentration of $\mathrm{Pu})$

Room $\quad \mathrm{t}_{1 / 2} \approx 100 \mathrm{~min}\left[1.3 \times 10^{-3} \mathrm{MPu}(\mathrm{IV})\right]$

$\mathrm{k}^{\prime \prime}=0.253\left[\mathrm{H}^{+}\right]^{-3} M^{-1} \mathrm{sec}^{-1}$

$\mathrm{E}_{\mathbf{a}}=144 \pm 6(34.5 \pm 1.5)$

$-\mathrm{d}[\mathrm{Pu}(\mathrm{IV})] / 3 \mathrm{dt}=\left[\mathrm{Pu}^{4+}\right]^{2}\left(2.56 \times 10^{-5}\left[\mathrm{H}^{+}\right]^{-3}+\right.$ $\left.3.9 \times 10^{-6}\left[\mathrm{H}^{+}\right]^{-4}\right) M \mathrm{sec}^{-1}$

Also studied in $\mathrm{HNO}_{3}$ solutions

$\mathrm{k}^{\prime \prime}=17\left[\mathrm{Cl}^{-}\right]^{1.9}\left[\mathrm{H}^{+}\right]^{0} M^{-1} \mathrm{sec}^{-1}$

Rate law corrected for $\mathrm{Cl}^{-}$complexing is

$-\mathrm{d}[\mathrm{Sn}(\mathrm{II})] / \mathrm{dt}=\left[\mathrm{Pu}^{4+}\right]\left[\mathrm{Sn}^{2+}\right]\left(332\left[\mathrm{Cl}^{-}\right]^{4}+\right.$

$\left.850\left[\mathrm{Cl}^{-}\right]^{5}\right) M \mathrm{sec}^{-1}$ at $20^{\circ} \mathrm{C}$

Room $\mathrm{t}_{1 / 2}>0.1 \mathrm{~min}$; rate is much lower in $\mathrm{H}_{2} \mathrm{SO}_{4}$

$25 \quad \mathrm{k}^{\prime \prime}=65.5\left[\mathrm{H}^{+}\right]^{-1} M^{-1} \mathrm{sec}^{-1}$

$\mathrm{E}_{\mathrm{a}}=72 \pm 3(17.3 \pm 0.7)$

(See Table 10.2)

$\mathrm{k}^{\prime}=11.9\left[\mathrm{H}^{+}\right]^{-1}+20.1\left[\mathrm{H}^{+}\right]^{-2} M^{-1} \sec ^{-1}$ in terms of $\left[\mathrm{Pu}^{4+}\right]$ and $\left[\mathrm{V}^{3+}\right.$

$\mathrm{E}_{\mathrm{a}}=74 \pm 2(17.7 \pm 0.5)$ and $92 \pm 1.6(22.1 \pm 0.4)$

for the respective rate constants 
Table 10.18

REDUCTION OF PLUTONIUM(V)

\begin{tabular}{|c|c|c|c|c|c|}
\hline Agent & $\begin{array}{c}\text { Typical } \\
\text { concentration, } M\end{array}$ & Solution & $\underset{{ }^{\circ} \mathrm{C}}{\text { Temp, }}$ & Results & Ref. \\
\hline $\mathrm{Fe}(\mathrm{II})$ & $1.6 \times 10^{-3}$ & $1 M(\mathrm{H}, \mathrm{Na}) \mathrm{ClO}_{4}$ & 25 & $\mathrm{k}^{\prime \prime}=30\left[\mathrm{H}^{+}\right] M^{-1} \sec ^{-1}$ (preliminary result) & 32 \\
\hline $\mathrm{HNO}_{2}$ & 0.1 & $0.2 M(\mathrm{H}, \mathrm{Na}) \mathrm{NO}_{3}$ & Room & Slower than the disproportionation of $\mathrm{Pu}(\mathrm{V})$ & 158 \\
\hline $\mathrm{H}_{2} \mathrm{O}_{2}$ & $2 \times 10^{-3}$ & $0.5 M \mathrm{HCl}$ & 25 & Slower than the disproportionation of $\mathrm{Pu}(\mathrm{V})$ & 158 \\
\hline$\Gamma^{-}$ & pH 2 & & Room & Very slow & 158 \\
\hline $\mathrm{NH}_{2} \mathrm{NH}_{3}^{+}$ & 0.05 & $0.5 M \mathrm{HCl}$ & Room & Slower than the disproportionation of $\mathrm{Pu}(\mathrm{V})$ & 158 \\
\hline $\mathrm{NH}_{3} \mathrm{OH}^{+}$ & 0.015 & $0.5 M \mathrm{HCl}$ & Room & Slower than the disproportionation of $\mathrm{Pu}(\mathrm{V})$ & 158 \\
\hline Pu(III) & & & & (See Table 10.14) & \\
\hline \multirow[t]{2}{*}{$\mathrm{Pu}(\mathrm{V})$} & $\sim 10^{-3}$ & $1 M(\mathrm{H}, \mathrm{Na}) \mathrm{ClO}_{4}$ & 25 & $\begin{array}{l}\mathrm{k}^{\prime \prime}=3.6 \times 10^{-3}\left[\mathrm{H}^{+}\right] M^{-1} \mathrm{sec}^{-1} \\
\Delta \mathrm{H}^{*}=79 \pm 4(19 \pm 1)\end{array}$ & 86 \\
\hline & & & & Also studied in oxalate solutions & 237,238 \\
\hline $\operatorname{Sn}(\mathrm{II})$ & $2 \times 10^{-3}$ & $0.5 M \mathrm{HCl}$ & 2.4 & $\mathrm{k}^{\prime \prime}<0.15 M^{-1} \sec ^{-1}$ & 141 \\
\hline $\mathrm{SO}_{2}$ & $2 \times 10^{-2}$ & $0.5 M \mathrm{HCl}$ & Room & Slower than the disproportionation of $\mathrm{Pu}(\mathrm{V})$ & 158 \\
\hline $\mathrm{Ti}^{3+}$ & $10^{-4}$ & $2 \mathrm{M}(\mathrm{H}, \mathrm{Na}) \mathrm{ClO}_{4}$ & 25 & Rapid; $\mathrm{k}^{\prime \prime} \gg 100 \mathrm{M}^{-1} \mathrm{sec}^{-2}$ & 133 \\
\hline $\mathrm{V}^{3+}$ & $2 \times 10^{-3}$ & $1 M \mathrm{HClO}_{4}$ & 2.4 & Slow $; \mathrm{k}^{\prime \prime} \ll 0.24 \mathrm{M}^{-1} \mathrm{sec}^{-1}$ & 134 \\
\hline
\end{tabular}


Table 10.19

REDUCTION OF PLUTONIUM(VI)

\begin{tabular}{|c|c|c|c|c|c|}
\hline Agent & $\begin{array}{c}\text { Typical } \\
\text { concentration, } M\end{array}$ & Solution & $\stackrel{\text { Temp., }}{{ }^{\circ} \mathrm{C}}$ & Results & Ref. \\
\hline $\mathrm{Cr}(\mathrm{II})$ & $2.5 \times 10^{-4}$ & $1 M \mathrm{HClO}_{4}$ & 14.5 & $\mathrm{k}^{\prime \prime}>10^{5} M^{-1} \sec ^{-1}$ & 130 \\
\hline EDTA & $2 \times 10^{-3}$ & $\begin{array}{l}1 M \mathrm{NaClO}_{4} \\
\mathrm{pH} 3 \text { to } 5\end{array}$ & Room & $\mathrm{k}^{\prime \prime}=4.3 \pm 1.6 M^{-1} \mathrm{sec}^{-1}$ & 239 \\
\hline $\mathrm{Fe}(\mathrm{II})$ & $4 \times 10^{-5}$ & $2 M(\mathrm{H}, \mathrm{Li}) \mathrm{ClO}_{4}$ & 25 & $\begin{array}{l}\mathrm{k}^{\prime \prime}=1000+\left(2 \times 10^{-4}+1.3 \times 10^{-3}\left[\mathrm{H}^{+}\right]\right)^{-1} M^{-1} \mathrm{sec}^{-1} \\
\text { Evidence for a binuclear intermediate } \\
\mathrm{E}_{\mathrm{a}}=22.6 \pm 0.8(5.4 \pm 0.2) \text { for first rate constant }\end{array}$ & 62 \\
\hline $\mathrm{H}_{2} \mathrm{C}_{2} \mathrm{O}_{4}$ & 0.02 & $1 M \mathrm{HClO}_{4}$ & 80 & $\begin{array}{l}\text { Conveniently measurable rate } \\
\mathrm{E}_{\mathrm{a}}=117(27.9)\end{array}$ & 240 \\
\hline \multirow[t]{2}{*}{$\mathrm{HNO}_{2}$} & 0.1 & $\begin{array}{l}0.1 M \mathrm{HNO}_{3}- \\
0.1 M \mathrm{NaNO}_{3}\end{array}$ & Room & $\mathrm{t}_{1 / 2}<25 \mathrm{sec}$ & 158 \\
\hline & 0.027 & $\begin{array}{l}0.1 M \mathrm{HNO}_{3}- \\
0.45 M \mathrm{NaNO}_{3}\end{array}$ & 20 & Initial $t_{1 / 2}=72 \mathrm{sec}$ & 241 \\
\hline $\mathrm{H}_{2} \mathrm{O}_{2}$ & $10^{-3}$ & $1 \mathrm{M}(\mathrm{H}, \mathrm{Na}) \mathrm{ClO}_{4}$ & 22 & $\begin{array}{l}\mathrm{k}^{\prime \prime}=6.3 \times 10^{-3}\left[\mathrm{H}^{+}\right]^{-1} M^{-1} \mathrm{sec}^{-1} \\
\mathrm{E}_{\mathrm{a}}=50 \pm 4(12 \pm 1) \\
\text { Rates also determined in } \mathrm{NO}_{3}^{-} \text {and } \mathrm{SO}_{4}^{2-} \text { solutions }\end{array}$ & 60 \\
\hline Hydroquinone & $10^{-4}$ & $1 M(\mathrm{H}, \mathrm{Li}) \mathrm{ClO}_{4}$ & 25 & $\begin{array}{l}\mathrm{k}^{\prime \prime}=3.2 \times 10^{3}\left[\mathrm{H}^{+}\right]^{-1} M^{-1} \mathrm{sec}^{-1} \\
\mathrm{E}_{\mathrm{a}}=65.7 \pm 0.4(15.7 \pm 0.1) \\
\text { Reaction is inhibited by } \mathrm{Pu}(\mathrm{V}) \text { but not by quinone }\end{array}$ & 146 \\
\hline $\mathrm{NH}_{3} \mathrm{OH}^{+}$ & 0.015 & $0.5 \mathrm{MHCl}$ & Room & $\begin{array}{l}\mathrm{t}_{1 / 2}=36 \mathrm{~min} ; \mathrm{NH}_{3} \mathrm{OH}^{+} \text {in excess, its dependence } \\
\text { not determined }\end{array}$ & 158 \\
\hline $\mathrm{N}_{2} \mathrm{H}_{5}^{+}$ & 0.02 & $2 M(\mathrm{H}, \mathrm{Na})\left(\mathrm{NO}_{3}, \mathrm{ClO}_{4}\right)$ & 40 & $\begin{array}{l}k^{\prime \prime}=(0.314 \pm 0.042)\left[\mathrm{H}^{+}\right]^{-1}\left[\mathrm{NO}_{3}^{-}\right]^{0} M^{-1} \mathrm{~min}^{-1} \\
\mathrm{E}_{\mathrm{a}}=67.4 \pm 0.8(16.1 \pm 0.2)\end{array}$ & 136 \\
\hline $\mathrm{Np}(\mathrm{IV})$ & & & & (See Table 10.7) & \\
\hline $\mathrm{Pu}(\mathrm{III})$ & & & & (See Table 10.14) & \\
\hline
\end{tabular}


Table 10.19 (Continued)

\begin{tabular}{|c|c|c|c|c|c|}
\hline Agent & $\begin{array}{c}\text { Typical } \\
\text { concentration, } M\end{array}$ & Solution & $\begin{array}{l}\text { Temp., } \\
{ }^{\circ} \mathrm{C}\end{array}$ & Results & Ref. \\
\hline $\operatorname{Sn}(I I)$ & & $2 \mathrm{MH}\left(\mathrm{Cl}, \mathrm{ClO}_{4}\right)$ & 20.2 & $\begin{array}{l}\mathrm{k}^{\prime \prime}=48[\mathrm{Cl}]^{1.49} \mathrm{M}^{-1} \mathrm{sec}^{-1} \\
\mathrm{E}_{\mathrm{a}}=43 \pm 2.5(10.2 \pm 0.6) \\
\text { Or, in terms of uncomplexed } \mathrm{Sn}^{2+} \text { and } \mathrm{PuO}_{2}^{2+}: \\
\mathrm{k}^{\prime}=2.1 \times 10^{3}\left[\mathrm{Cl}^{-}\right]^{3}+4.5 \times 10^{3}\left[\mathrm{Cl}^{-}\right]^{4} \mathrm{M}^{-1} \mathrm{sec}^{-1} \\
\Delta \mathrm{H}^{*}=59 \pm 8(14 \pm 2) \text { and } 62 \pm 6(14.8 \pm 1.5) \text { for the } \\
\quad \text { respective rate constants } \dagger \\
\text { Evidence that reaction is a two-electron process }\end{array}$ & 141 \\
\hline Ti(III) & $10^{-4}$ & $2 M(\mathrm{H}, \mathrm{Na}) \mathrm{ClO}_{4}$ & 25 & $\begin{array}{l}\mathrm{k}^{\prime \prime}=108\left[\mathrm{H}^{+}\right]^{-1} M^{-1} \mathrm{sec}^{-1} \\
\Delta \mathrm{H}^{*}=43 \pm 2(10.3 \pm 0.4)\end{array}$ & 133 \\
\hline$V(111)$ & $7 \times 10^{-4}$ & $2 M(\mathrm{H}, \mathrm{Na}) \mathrm{ClO}_{4}$ & 25 & $\begin{array}{l}\mathrm{k}^{\prime \prime}=2.12\left[\mathrm{H}^{+}\right]^{-1}+0.228\left[\mathrm{H}^{+}\right]^{-2} M^{-1} \mathrm{sec}^{-1} \\
\mathrm{E}_{\mathrm{a}}=67 \pm 2(16.1 \pm 0.4) \text { in } 1 M \mathrm{HClO}_{4}\end{array}$ & 134 \\
\hline
\end{tabular}

$\dagger$ Original data recalculated.

Table 10.20

REDUCTION OF PLUTONIUM(VII)

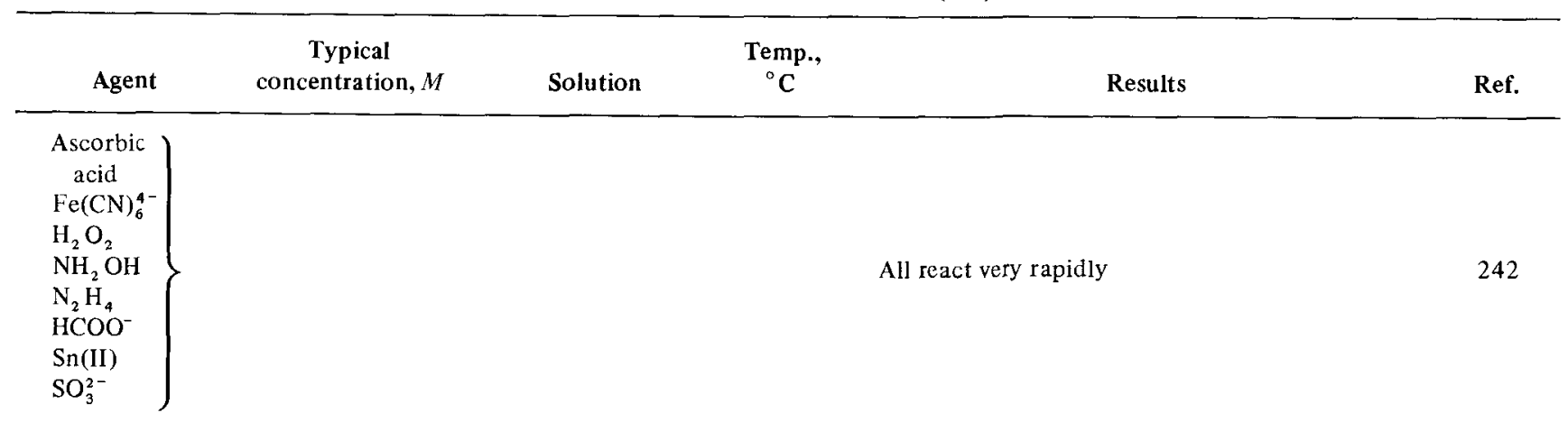




\begin{tabular}{|c|c|c|c|c|c|}
\hline $\mathrm{CH}_{3} \mathrm{OH}$ & 0.55 & $2.5 M \mathrm{KOH}$ & & $\begin{array}{l}t_{1 / 2}=69 \mathrm{sec}\left(105 \mathrm{sec} \text { for } \mathrm{C}_{2} \mathrm{H}_{5} \mathrm{OH} \text { under the }\right. \\
\text { same conditions) }\end{array}$ & 242 \\
\hline $\mathrm{C}_{2} \mathrm{O}_{4}^{2-}$ & & & & Reacts slower than the reaction with $\mathrm{H}_{2} \mathrm{O}$ & 242 \\
\hline $\mathrm{CH}_{3} \mathrm{COO}^{-}$ & & & & Reacts slower than the reaction with $\mathrm{H}_{2} \mathrm{O}$ & 242 \\
\hline $\mathrm{H}_{2} \mathrm{CO}$ & $4 \times 10^{-3}$ & $2.5 M \mathrm{KOH}$ & & $\mathrm{t}_{1 / 2}=75 \mathrm{sec}$ & 242 \\
\hline $\mathrm{H}_{2} \mathrm{O}$ & 55.5 & $\begin{array}{l}0.06 M \mathrm{MaOH}- \\
0.94 M \mathrm{NaNO}_{3}\end{array}$ & 25 & $\begin{array}{l}\frac{-\mathrm{d}[\mathrm{Pu}(\mathrm{VII})]}{\mathrm{dt}}=\frac{4.7 \times 10^{-4}[\mathrm{Pu}(\mathrm{VII})]^{\hat{z}}}{\mathrm{~K}_{0}[\mathrm{Pu}(\mathrm{VII})]_{0}+\left(1-\overline{\mathrm{K}}_{0}\right)[\mathrm{Pu}(\mathrm{VII})]} \\
\text { (the value of the constant } \mathrm{K}_{0} \text { is not given) } \\
\text { The rate is proportional to }\left[\mathrm{OH}^{-1}\right]^{-1} \text { and is } \\
\text { catalyzed by } \mathrm{Fe}(\mathrm{III}), \mathrm{Cu}(\mathrm{II}), \mathrm{Ni}(\mathrm{II}) \text {, and } \mathrm{Co}(\mathrm{III})\end{array}$ & 243 \\
\hline$\Gamma^{-}$ & $6.2 \times 10^{-4}$ & $1 M \mathrm{KOH}$ & 25 & $\begin{array}{l}\mathrm{k}^{\prime \prime}=110 \mathrm{M}^{-1} \mathrm{sec}^{-1}, \text { first power in each reactant } \\
\text { Rate is proportional to }[\mathrm{KOH}]^{-3.6}, \mu \text { not constant } \\
\text { Product is } \mathrm{IO}^{-} \text {if }\left[\mathrm{OH}^{-}\right]<2 M \\
\mathrm{E}_{\mathrm{a}}=25(6)\end{array}$ & 242 \\
\hline $\mathrm{IO}_{3}^{-}$ & & $1 M \mathrm{KOH}$ & 25 & $\begin{array}{l}\mathrm{k}^{\prime \prime}=18.3 \mathrm{M}^{-1} \mathrm{sec}^{-1}, \text { first power in each reactant } \\
\mathrm{E}_{\mathrm{a}}=25(5.9) \\
\text { Rate increases linearly with }[\mathrm{KOH}]\end{array}$ & 242 \\
\hline $\mathrm{Np}(\mathrm{VI})$ & & & & (See Table 10.9) & \\
\hline $\mathrm{S}_{2} \mathrm{O}_{3}^{2-}$ & & $2.5 M \mathrm{KOH}$ & & $t_{1 / 2}=120 \mathrm{sec}$ & 242 \\
\hline
\end{tabular}


Table 10.21

OXIDATION OF AMERICIUM(III)

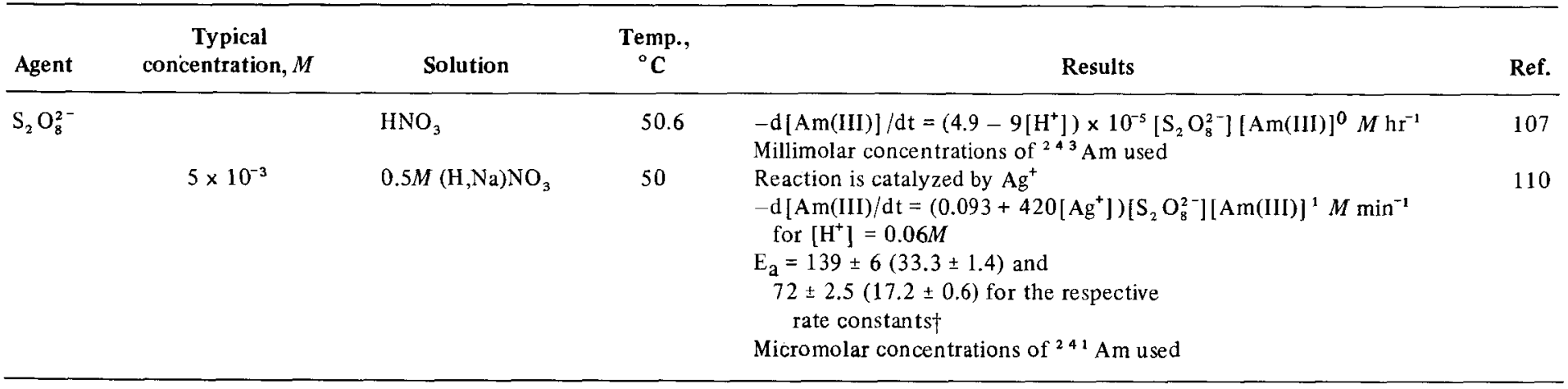

$\lceil$ Original data recalculated.

Table 10.22

OXIDATION OF AMERICIUM(V)

\begin{tabular}{|c|c|c|c|c|c|}
\hline Agent & $\begin{array}{l}\text { Typical } \\
\text { concentration, } M\end{array}$ & Solution & $\underset{{ }^{\circ} \mathrm{C}}{\text { Temp., }}$ & Results & Ref. \\
\hline $\operatorname{Am}(V)$ & $2.5 \times 10^{-3}$ & $2 M(\mathrm{H}, \mathrm{Li}) \mathrm{ClO}_{4}$ & 75.7 & $\begin{array}{l}\mathrm{k}^{\prime \prime}=(6.9 \pm 1) \times 10^{-4}\left[\mathrm{H}^{+}\right]^{2}+(4.6 \pm 0.7) \times 10^{-4}\left[\mathrm{H}^{+}\right]^{3} M^{-1} \mathrm{sec}^{-1} \\
\mathrm{E}_{\mathrm{a}}=57 \pm 2(13.6 \pm 0.5) \text { for }\left[\mathrm{H}^{+}\right]=1.92 M(\mathrm{r})\end{array}$ & 113 \\
\hline $\mathrm{S}_{2} \mathrm{O}_{8}^{2-}$ & & $\mathrm{HNO}_{3}$ & 50.6 & $\begin{array}{l}-\mathrm{d}[\mathrm{Am}(\mathrm{V})] / \mathrm{dt}=\left(1.5-2.7\left[\mathrm{H}^{+}\right]\right) \times 10^{-4}\left[\mathrm{~S}_{2} \mathrm{O}_{8}^{2-}\right][\mathrm{Am}(\mathrm{V})]^{6} \mathrm{M} \mathrm{hr}^{-1} \\
\text { Millimolar concentrations of }{ }^{243} \mathrm{Am} \text { used }\end{array}$ & 107 \\
\hline
\end{tabular}


Table 10.23

REDUCTION OF AMERICIUM(V)

\begin{tabular}{lcccc}
\hline Agent & $\begin{array}{c}\text { Typical } \\
\text { concentration, } M\end{array}$ & Solution & $\begin{array}{c}\text { Temp., } \\
{ }^{\circ} \mathrm{C}\end{array}$ & Results \\
\hline $\mathrm{H}_{2} \mathrm{O}_{2}$ & 0.02 & $0.1 M \mathrm{HClO}_{4}$ & 25 & $\begin{array}{l}\mathrm{k}^{\prime \prime}=14.8 \pm 1.5 M^{-1} \mathrm{hr}^{-1} \\
\mathrm{E}_{\mathrm{a}}=55 \pm 9(13.1 \pm 2.2) \\
2{ }^{41} \text { Am was used }\end{array}$
\end{tabular}

Table $\mathbf{1 0 . 2 4}$

REDUCTION OF AMERICIUM(VI)

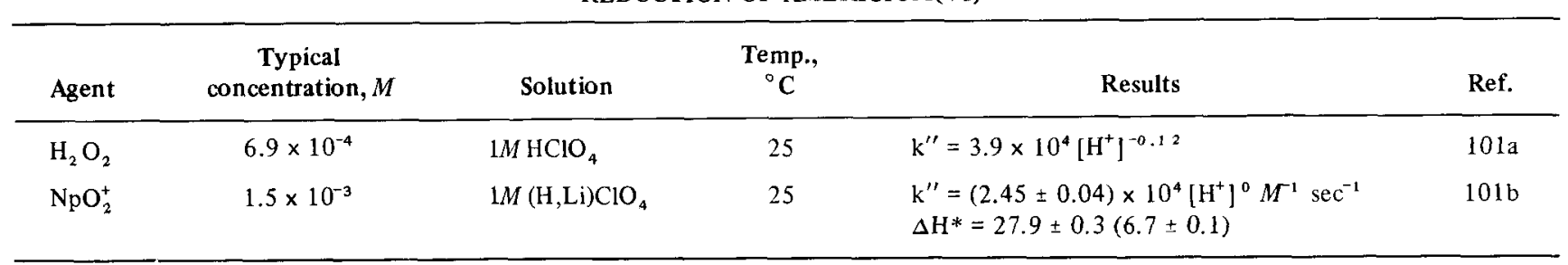




\section{REFERENCES}

1. J. J. Katz and G. T. Seaborg, The Chemistry of the Actinide Elements, John Wiley \& Sons, Inc., New York, 1957.

2. E. S. Kritchevsky and J. C. Hindman, J. Amer. Chem. Soc., $71: 2096$ (1949).

3. M. H. Rand and O. Kubaschewski, The Thermochemical Properties of Uranium Compounds, p. 11, Wiley-Interscience, New York, 1963.

4. D. Cohen and J. C. Hindman, J. Amer. Chem. Soc., 74: 4679, 4682 (1952).

5. S. W. Rabideau, J. Amer. Chem. Soc., 78: 2705 (1956).

6. S. W. Rabideau and H. D. Cowan, J. Amer, Chem. Soc., 77: 6145 (1955).

7. L. J. Nugent, R. D. Baybarz, J. L. Burnett, and J. L. Ryan, J. Inorg. Nucl. Chem., 33: 2503 (1971).

8. L. Eyring, H. R. Lohr, and B. B. Cunningham, J. Amer. Chem. Soc., 74: 1186 (1952).

9. R. A. Penneman, J. S. Coleman, and T. K. Keenan, J. Inorg. Nucl. Chem., 17: 138 (1961).

10. G. C. Farrington and J. J. Lingane, Anal. Chim. Acta., 60: 175 (1972).

11. S. R. Gunn and B. B. Cunningham, J. Amer. Chem. Soc., 79: 1563 (1957).

12. T. W. Newton, J. Plys. Chem., 74: 1655 (1970).

13. R. A. Penneman and L. B. Asprey, The Formal Potential of the Am(V)-Am(VI) Couple, USAEC Report AECU-936, Los Alamos Scientific Laboratory, Sept. 5, 1950.

14. V. P. Zaitseva, Sov. Radiochem. (Engl. Transl.), 13: 679 (1971).

15. L. V. Coulter, K. S. Pitzer, and W. M. Latimer, J. Amer. Chem. Soc., 62: 2845 (1940).

16. J. R. Brand and J. W. Cobble, Inorg. Chem., 9: 912 (1970).

17. R. J. Hinchey and J. W. Cobble, Inorg. Chem., 9: 922 (1970).

18. R. T. Wang and J. H. Espenson, J. Amer. Chem. Soc., 93: 380 (1971).

19. K. A. Kraus and F. Nelson, J. Amer. Chem. Soc., 72: 3901 (1950).

20. T. W. Newton and F. B. Baker, Inorg. Chem., 4: 1166 (1965).

21. R. Sjoblom and J. C. Hindman, J. Amer. Chem. Soc., 73: 1744 (1951).

22. A. Sato and S. Suzuki, Bull. Chem. Soc. Jap., $41: 2650$ (1968).

23. P. G. Hagan and J. M. Cleveland, J. Inorg. Nucl. Chem., 28: 2905 (1966). 
24. J. C. Sullivan and A. J. Zielen, Inorg. Nucl. Chem. Lett., 5: 927 (1969):

25. D. Cohen, J. Inorg. Nucl. Chem. 18: 211 (1961).

26. R. A. Penneman and T. K. Keenan, The Radiochemistry of Americium and Curium, USAEC Report NAS-NS-3006, National Research Council. Committee on Nuclear Science, June 3, 1960.

27. J. M. Cleveland, The Chemistry of Plutonium, p. 39, Gordon and Breach, Science Publishers, Inc., New York, 1970.

28. Cornelius Keller, The Chemistry of the Transuranium Elements, Vol. 3, Kernchemie in Einzeldarstellungen, Verlag Chemie $\mathrm{GmbH}$, Weinheim/Bergstr., Germany.

29. J. C. Sullivan, Inorg. Chem., 3: 315 (1964).

30. T. W. Newton and F. B. Baker, Inorg. Chem., 1: 368 (1962).

31. J. C. Sullivan, J. Amer. Chem. Soc., 84: 4256 (1962).

32. T. W. Newton and M. J. Burkhart, Inorg. Chem., 10: 2323 (1971).

33. R. K. Murmann and J. C. Sullivan, Inorg. Chem., 6: 892 (1967).

34. J. C. Sullivan, J. C. Hindman, and A. J. Zielen, J. Amer. Chem. Soc., 83: 3373 (1961).

35. S. Glasstone, K. Laidler, and H. Eyring, The Theory of Rate Processes, McGraw-Hill Book Company, New York, 1941 .

36. A. Haim, Inorg. Chem., 5: 2081 (1966).

37. H. S. Harned and B. B. Owen, The Physical Chemistry of Electrolytic Solutions, 3rd ed., Chap. 14, Reinhold Publishing Corporation, New York, 1958.

38. J. N. Brönsted, J. Amer. Chem. Soc., 44: 877 (1922); R. A. Robinson and R. H. Stokes, Electrolyte Solutions, 2nd ed., Butterworth \& Co. (Publishers) Ltd., London, 1965.

39. A. J. Zielen and J. C. Sullivan, J. Phys. Chem., 66: 1065 (1962).

40. S. W. Rabideau and J. F. Lemons, J. Amer. Chem. Soc, 73: 2895 (1951).

41. R. A. Marcus, J. Chem Phys., 43: 679 (1965); see also Annu. Rev. Phys. Chem., 17: 119 (1964).

42. P. Debye, Trans. Electrochem. Soc., 82: 268 (1942).

43. H. L. Friedman, J. Phys. Chem., 70: 3931 (1966).

44. S. W. Rabideau and R. J. Kline, J. Inorg. Nucl. Chem., 14: 91 (1960).

45. W. M. Latimer, Oxidation Potentials, 2nd ed., Prentice-Hall, Inc., Englewood Cliffs, N. J., 1952.

46. R. H. Betts, Can. J. Chem., 33: 1780 (1955).

47. J. C. Sullivan and R. C. Thompson, Inorg. Chem., 6: 1795 (1967).

48. E. H. Appelman and J. C. Sullivan, J. Phys. Chem., 66: 442 (1962).

49. T. W. Newton and F. B. Baker, J. Phys. Chem., 69: 176 (1965).

50. T. W. Newton and F. B. Baker, J. Phys. Chem., 68: 228 (1964).

51. T. W. Newton and F. B. Baker, J. Phys. Chem., 70: 1943 (1966).

52. M. M. Taqui Khan and A. E. Martell, J. Amer. Chem. Soc., $91: 4668$ (1969).

53. V. P. Shilov, N. N. Krot, and A. D. Gel'man, Sov. Radiochem. (Engl. Transl.), 12: 201 (1970).

54. R. C. Thompson and J. C. Sullivan, J. Amer. Chem. Soc., 92: 3028 (1970).

55. M. A. Thompson, J. C. Sullivan, and E. Deutsch, J. Amer. Chem. Soc., 93: 5667 (1971).

56. A. J. Zielen and D. Cohen, J. Phys. Chem., 74: 394 (1970).

57. A. G. Sykes, Kinetics of Inorganic Reactions, 1st ed., pp. 170-172, Pergamon Press, Inc., New York, 1966.

58. A. J. Zielen, J. C. Sullivan, D. Cohen, and J. C. Hindman, J. Amer. Chem. Soc., 80: 5632 (1958).

59. M. G. Evans and N. Uri, Trans. Faraday Soc., 45: 224 (1949).

60. B. Lesigne, French Report CEA-R-3168, December 1967; see Kinetic Study of the Reduction of Hexavalent Plutonium by Hydrogen Peroxide in Acid Solution, USAEC Report RFP-Trans-47, for English translation.

61. T. W. Newton, J. Phys. Chem., 62: 943 (1958). 
62. T. W. Newton and F. B. Baker, J. Phys. Chem., 67: 1425 (1963).

63. R. C. Thompson and J. C. Sullivan, J. Amer. Chem. Soc., 89: 1098 (1967).

64. J. P. Hunt and H. Taube, J. Chem. Phys., 18: 757 (1950).

65a. R. Buchacek and G. Gordon, Inorg. Chem., 11: 2154 (1972).

65b. E. A. Kanevskii and L. A. Fedorova, Sov. Radiochem. (Engl. Transl.), 3: 108 (1961).

66. G. Gordon and F. Feldman, Inorg. Chem., 3: 1728 (1964).

67. J. H. Espenson and R. T. Wang, Inorg. Chem., 11 : 955 (1972).

68. F. H. Westheimer, Chem. Rev., 45: 419 (1949).

69. E. A. M. Wetton and W. C. E. Higginson, J. Chem. Soc., 5890 (1965).

70a. G. Gordon and H. Taube, Inorg. Chem, 1: 69 (1962).

70b. G. Gordon and H. Taube, I. Inorg. Nucl. Chem., 16: 272 (1961).

71. V. I. Spitsyn et al., J. Inorg. Nucl. Chem., $31: 2733$ (1969).

72. V. P. Shilov, N. N. Krot, and A. D. Gel'man, Sov. Radiochem. (Engl. Transl.), 12: 888 (1970).

73. J. C. Sullivan and T. W. Newton, unpublished preliminary results, Los Alamos Scientific Laboratory, 1969.

74. T. K. Keenan, J. Phys. Chem., 61: 1117 (1957).

75. D. Cohen, J. C. Sullivan, E. S. Amis, and J. C. Hindman, J. Amer. Chem. Soc., $78: 1543$ (1956), and references cited there.

76. T. W. Newton and R. B. Fulton, J. Phys. Chem., 74: 2797 (1970).

77. R. B. Fulton and T. W. Newton, J. Phys. Chem., 74: 1661 (1970).

78. S. W. Rabideau and R. J. Kline, J. Phys. Chem., 62: 617 (1958).

79. J. C. Hindman, J. C. Sullivan, and D. Cohen, J. Amer. Chem. Soc., 80: 1812 (1958).

80. C. Lavallee and T. W. Newton, Inorg. Chém., $11: 2616$ (1972).

81. A. G. Rykov, G. A. Timofeev, and C. N. Yakovlev, Sov. Radiochem. (Engl. Transl.), 11: 403 (1969).

82. T. W. Newton, J. Phys. Chem., 63: 1493 (1959).

83. J. C. Sullivan, A. J. Zielen, and J. C. Hindman, J. Amer. Chem. Soc,, 82: 5288 (1960).

84. J. C. Hindman, J. C. Sullivan, and D. Cohen, J. Amer. Chem. Soc., 76: 3278 (1954).

85. J. C. Sullivan, D. Cohen, and J. C. Hindman, J. Amer. Chem. Soc., 79: 4029 (1957).

86. S. W. Rabideau, J. Amer. Chem. Soc., 79: 6350 (1957).

87. A. G. Rykov, G. A. Timofeev, and V. M. Chistyakov, Sov. Radiochem. (Engl. Transl.), 11 : 443 (1969).

88. N. K. Shastri, E. S. Amis, and J. O. Wear, J. Inorg. Nucl. Chem., 27: 2413 (1965).

89. J. C. Sullivan, D. Cohen, and J. C. Hindman, J. Amer. Chem. Soc., 76: 4275 (1954).

90. M. Lefort and X. Tarrago, J. Phys. Chem., 63: 833 (1959).

91. M. Kasha, Reactions Between Plutonium Ions in Perchloric Acid Solution: Rates, Mechanisms, and Equilibria, in The Transuranium Elements, Chap. 3.100, pp. 295-334, Division IV, Vol. 14B, National Nuclear Energy Series, McGraw-Hill Book Company, New York, 1949.

92. M. Pagés, Radiolyse des solutions aqueuses de plutonium, French Report, CEA-1420, Aug. 23, 1960.

93. S. W. Rabideau, M. J. Bradley, and H. D. Cowan, Alpha-Particle Oxidation and Reduction in Aqueous Plutonium Solutions, USAEC Report LAMS-2236, Los Alamos Scientific Laboratory, June 1958.

94. A. J. Zielen, J. C. Sullivan, and D. Cohen, J. Inorg. Nucl. Chem., 7: 378 (1958).

95. M. Cottin, J. Chim Phys., 53: 903 (1956).

96. F. J. Miner and J. R. Seed, Chem. Rev., 67: 299 (1967).

97. P. I. Artyukhin, V. I. Medvedovskii, and A. D. Gel'man, Radiokhimiya, 1: 131 (1959). (In Russian.) For translation see The Effect of $\alpha$-Radiation on the Valence States of Plutonium in Nitric Acid Solutions, USAEC Report RFP-Trans-5, translated by H. W. Miller, Dow Chemical Co. 
98. V. D. Nikol'skii, M. E. Pozharskaya, and B. G. Pozharskii, Sov. Radiochem. (Engl. Transl.), 2: 57 (1960).

99. L. B. Asprey and R. A. Penneman, J. Amer, Chem. Soc., 83: 2200 (1961).

100. E. Yamir, M. Givon, and Y. Marcus, Inorg. Nucl. Chem. Lett., 5: 369 (1969).

101. A. A. Zaitsev, V. N. Kosyakov, A. G. Rykov, Yu. P. Sobolev, and G. N. Yakovlev, At. Energ. (USSR), 7: 37 (1959).

102a. M. Woods, A. Cain, and J. C. Sullivan, J. Inorg. Nucl. Chem., 36: 2605 (1974).

102b. M. Woods and J. C. Sullivan, Inorg. Chem., 13: 2774 (1974).

103. L. B. Asprey and S. E. Stephanou, The Auto-Reduction of Am(VI) and Am(V) in Dilute Acid, USAEC Report AECU-924, Los Alamos Scientific Laboratory, Nov. 10, 1950.

104. G. R. Hall and T. L. Markin, J. Inorg. Nucl. Chem., 4: 296 (1957).

105. D. Gourisse, Oxidation-Reduction Reactions with Transuranic Elements in Solution, French Report CEA-N-1441, November 1971.

106. A. A. Zaitsev, V. N. Kosyakov, A. G. Rykov, Yu. P. Sobolev, and G. N. Yakovlev, Sov. Radiochem. (Engl. Transl.), 2: 348 (1960).

107. V. A. Ermakov, A. G. Rykov, G. A. Timofeev, and G. N. Yakovlev, Sov. Radiochem. (Engl. Transl.), 13: 851 (1971).

108. I. M. Kolthoff and I. K. Miller, J. Amer. Chem. Soc., 73: 3055 (1951).

109. V. A. Ermakov, A. G. Rykov, G. A. Timofeev, A. V. Dzhadav, and G. N. Yakovlev, Sov. Radiochem. (Engl. Transl.), 15: 381 (1973).

110. A. Ohyoshi, A. Jyo, and T. Shinohara, Bull. Chem. Soc. Jap., 44: 3047 (1971).

111. G. R. Hall and P. D. Herniman, J. Chem. Soc,, 1954: 2214 (1954).

112. S. E. Stephanou, L. B. Asprey, and R. A. Penneman, The Disproportionation of Americium(V), USAEC Report AECU-925, Los Alamos Scientific Laboratory, Nov. 17, 1950.

113. J. S. Coleman, Inorg. Chem., 2: 53 (1963).

114. T. W. Newton and N. A. Daugherty, J. Phys. Chem., 71: 3768 (1967).

115. J. D. White and T. W. Newton, J. Phys. Chem., 75: $2117(1971)$.

116. D. K. Lavallee, C. Lavallee, J. C. Sullivan, and E. Deutsch, Inorg. Chem., 12: 570 (1973).

117. M. J. Burkhart and T. W. Newton, J. Phys. Chem., 73: 1741 (1969).

118. R. C. Thompson and J. C. Sullivan, J. Amer. Chem. Soc., 89: 1096 (1967).

119. T. W. Newton and H. D. Cowan, J. Phys. Chem., 64: 244 (1960).

120. S. W. Rabideau and R. J. Kline, J. Phys. Chem., 64: 193 (1960).

121. J. R. Huizenga and L. B. Magnusson, J. Amer. Chem. Soc., 73: 3202 (1951).

122. A. C. Harkness and J. Halpern, J. Amer. Chem. Soc., 81: 3526 (1959).

123. F. B. Baker, T. W. Newton, and M. Kahn, J. Phys. Chem., 64: 109 (1960).

124. A. Ekstrom and A. B. McLaren, J. Inorg. Nucl. Chem., 33: 3511 (1971).

125. A. G. Rykov and G. N. Yakovlev, Sov. Radiochem. (Engl. Transl.), 8: 20 (1966).

126. E. Rona, J. Amer. Chem. Soc., 72: 4339 (1950).

127. V. S. Koltunov and G. I. Zhuravleva, Sov. Radiochem. (Engl. Transl.), 15: 374 (1973).

128. A. Ekstrom, Inorg. Chem, 12: 2455 (1973).

129. A. Ekstrom and A. McLaren, J. Inorg. Nucl. Chem., 34: 2015 (1972).

130. A. Ekstrom and Y. Farrar, Inorg. Chem., 11: 2610 (1972).

131. A. Ekstrom and D. A. Johnson, J. Inorg. Nucl. Chem., 36: 2557 (1974).

132. J. C. Sheppard, J. Phys. Chem, 68: 1190 (1964).

133. S. W. Rabideau and R. J. Kline, J. Phys. Chem., 63: 1502 (1959).

134. S. W. Rabideau, J. Phys. Chem., 62: 414 (1958).

135. V. S. Koltunov and M. F. Tikhonov, Sov. Radiochem. (Engl. Transl.), 15: 83 (1973).

136. V. S. Koltunov and G. I. Zhuravleva, Sov, Radiochem. (Engl. Transl.), 15: 73 (1973).

137. Mary Thompson and J. C. Sullivan, Inorg. Chem., 11: 1707 (1972).

138. K, O. Watkins, J. C. Sullivan, and E. Deutsch, Inorg. Chem., 13: 1712 (1974).

139. D. Cohen, J. C. Sullivan, and J. C. Hindman, J. Amer. Chem. Soc., 77: 4964 (1955). 
140. S. W. Rabideau, J. Phys. Chem., 64: 1491 (1960).

141. S. W. Rabideau and B. J. Masters, J. Phys. Chem., 65: 1256 (1961).

142. A. G. Rykov, V. Y. Vasel'ev, and G. N. Yakovlev, Sov. Radiochem. (Engl. Transl.), 8: 31 (1966).

143. J. C. Sullivan, J. Amer. Chem. Soc., 87: 1495 (1965).

144. L. Adamcikova and L. Treindl, Collect. Czech. Chem. Commun., 37: 762 (1972).

145. K. Reinschmiedt, J. C. Sullivan, and M. Woods, Inorg. Chem., 12: 1639 (1973).

146. T. W. Newton, J. Inorg. Nucl. Chem, 36: 639 (1974).

147. J. M. Cleveland, Inorg. Chem., 6: 1302 (1967).

148. National Bureau of Standards, Technical Note 270, U.S. Government Printing Office, Washington, D. C.

149. S. W. Rabideau, J. Amer. Chem. Soc., 79: 3675 (1957).

150. A. G. Rykov and G. A. Timofeev, Sov. Radiochem. (Engl. Transl.), 14: 718 (1972).

151. H. A. Bent, J. Phys. Chem., 60: 123 (1956).

152. S. W. Benson, J. Amer. Chem. Soc., 80: 5151 (1958).

153. A. A. Frost and R. G. Pearson, Kinetics and Mechanism, 2nd ed., p. 145, John Wiley \& Sons, Inc., New York, 1961.

154. V. P. Kazakov, B. I. Peshchevitskii, and A. M. Erenburg, Sov. Radiochem. (Engl. Transl.), 6 : 282 (1964).

155. D. Gourisse, French Report CEA-R-3079, 1966 (In French); see Kinetics of Transuranium Element Oxidation-Reduction Reactions in Solution, USAEC Report ORNL-tr-1644, translated by G. L. Boisvert, Oak Ridge National Laboratory.

156. T. W. Newton and S. W. Rabideau, J. Phys. Chem., 63: 365 (1959).

157. L. B. Magnusson, J. C. Hindman, and T. J. LaChapelle, Chemistry of Neptunium. Kinetics and Mechanisms of Aqueous Oxidation-Reduction Reactions of Neptunium, in The Transuranium Elements, Chap. 15.11, pp. 1134-1148, Division IV, Vol. 14B, National Nuclear Energy Series, McGraw-Hill Book Company, New York, 1949.

158. R. E. Connick, Oxidation States, Potentials, Equilibria, and Oxidation-Reduction Reactions of Plutonium, in The Actinide Elements, Chap. 8, pp. 221-300, Division IV, Vol. 14A, National Nuclear Energy Series, McGraw-Hill Book Company, New York, 1954.

159. V. F. Peretrukhin, N. N. Krot, and A. D. Gel'man, Sov. Radiochem. (Engl. Transl.), 12: 85 (1970).

160. R. T. Wang and J. H. Espenson, J. Amer. Chem. Soc., 93: 1629 (1971).

161. V. F. Peretrukhin, N. N. Krot, and A. D. Gel'man, Sov. Radiochem. (Engl. Transl.), 12: 81 (1970).

162. C. Avrain and M. Duflo-Plissonnier, Rev. Chim. Miner., 7: 701 (1970).

163. G. Gordon and A. Andrews, Inorg. Chem., 3: 1733 (1964).

164. L. M. Frolova, V. S. Lakaev, G. A. Timofeev, and A. G. Rykov, Sov. Radiochem. (Engl. Transl.), 14: 786 (1972).

165. Y. A. El-Tantawy and A. I. Abu-Shady, Z. Phys. Chem. N. F., 84: 225 (1973).

166. L. A. Fedorova, Sov. Radiochem. (Engl. Transl.), 6: 37 (1964).

167. L. A. Fedorova and E. A. Kanevskii, Kinet. Catal. (USSR) (Engl. Transl.), 3: 332 (1962).

168. A. G. Rykov, V. Ya. Vasil'ev, G. A. Timofeev, and L. M. Frolova, Sov. Radiochem. (Engl. Transl.), 14: 73 (1972).

169. V. S. Koltunov and V. I. Marchenko, Sov. Radiochem. (Engl. Transl.), 15: 77 (1973).

170. L. Treindl and L. Adamcikova, Chem. Zvesti, 27: 433 (1973).

171. F. B. Baker and T. W. Newton, J. Phys. Chem., 65: 1897 (1961).

172. J. Sobkowski, Rocz. Chem., 37: 1019 (1963).

173. J. Sobkowski, Rocz. Chem., 40: 271 (1966).

174. J. Halpern and J. G. Smith, Can J. Chem., 34: 1419 (1956).

175. P. Biddle, J. H. Miles, and M. J. Waterman, J. Inorg. Nucl. Chem., 28: 1736 (1966).

176. E. A. Kanevskii and L. A. Fedorova, Sov. Radiochem. (Engl. Transl.), 2(5): 48 (1960). 
177. C. M. Love, L. P. Quinn, and C. H. Brubaker, Jr., J. Inorg. Nucl. Chem., 27: 2183 (1965).

178. F. A. Jones and E. S. Amis, J. Inorg. Nucl. Chem., 26: 1045 (1964).

179. J. O. Wear, J. Chem. Soc., 5596 (1965).

180. B. J. Masters and L. L. Schwartz, J. Amer. Chem. Soc., 83: 2620 (1961).

181. K. Bächmann and K. H. Lieser, Ber. Bunsenges. Phys. Chem., 69: 522 (1965).

182. D. M. Mathews, J. D. Hefley, and E. S. Amis, J. Phys. Chem., 63: 1236 (1959).

183. B. McDuffie and C. N. Reilley, Anal. Chem., 38: 1881 (1966).

184. D. T. Pence and G. L. Booman, Anal. Chem., 38: 1112 (1966).

185. A. I. Stabrovskii, Russ. J. Inorg. Chem. (Engl. Transl.), 16: 881 (1971).

186. C. F. Baes, Jr., J. Phys. Chem., 60: 805 (1956).

187. R. T. Mayhew and E. S. Amis, J. Inorg. Nucl. Chem., 35: 4245 (1973).

188. R. L. Moore, J. Amer. Chem. Soc., 77: 1504 (1955).

189. T. P. Logan and J. P. Birk, Inorg. Chem., 12: 2464 (1973).

190. S. Minc, J. Sobkowski, and M. Stok, Nukleonika, 10: 747 (1965).

191. T. W. Newton, G. E. McCrary, and W. G. Clark, J. Phys. Chem., 72: 4333 (1968).

192. C. S. Burgener and J. C. Sullivan, Inorg. Chem., 9: 2604 (1970).

193. A. G. Rykov, G. A. Timofeev, V. M. Chistyakov, and G. M. Yakovlev, Khim. Transuranovykh Oskolochnykh Elem., Akad. Nauk SSSR, Otd. Obsch. Tekh. Khim., 1967: 133. (In Russian.) See also Chem. Abstr., 69: 30559f (1968).

194. A. G. Rykov, V. Ya. Vasil'ev, G. A. Timofeev, and L. M. Frolova, Sov. Radiochem. (Engl. Transl.), 14: 123 (1972).

195. J. C. Hindman, J. C. Sullivan, and D. Cohen, J. Amer. Chem. Soc., 81: 2316 (1959).

196. A. G. Rykov and G. N. Yakovlev, Sov. Radiochem. (Engl. Transl.), 8: 27 (1966).

197a. R. C. Thompson, J. Amer. Chem. Soc., 93: 7315 (1971).

197b. G. C. Knight and R. C. Thompson, Inorg. Chem., 12: 63 (1973).

198. T. H. Siddall and E. K. Dukes, J. Amer. Chem. Soc., $81: 790$ (1959).

199. J. L. Swanson, Oxidation of Neptunium(V) in Nitric Acid Solution: Laboratory Study of Rate Accelerating Materials, USAEC Report BNWL-1017, Battelle-Northwest, Pacific Northwest Laboratory, April 1969.

200. D. Cohen, J. C. Hindman, and J. C. Sullivan, J. Amer. Chem. Soc., 76: 352 (1954).

201. J. C. Sullivan, D. Cohen, and J. C. Hindman, J. Amer. Chem. Soc., 79: 3672 (1957).

202. E. K. Dukes, Oxidation of Neptunium(V) by Vanadium(V), USAEC Report DP-434, Du Pont de Nemours (E. I.) and Co., November 1959.

203. J. M. Cleveland and G. J. Werkema, Nature, 215: 732 (1967).

204. V. P. Shilov, N. N. Krot, and A. D. Gel'man, Sov. Radiochem. (Engl. Transl.), 12: 870 (1970).

205. N. N. Krot, M. P. Medfod'eva, V. P. Shilov, and A. D. Gel'man, Sov. Radiochem. (Engl. Transl.), 12: 438 (1970).

206. V. P. Shilov, N. N. Krot, and A. D. Gel'man, Sov. Radiochem. (Engl. Transl.), 13: 7 (1971).

207. E. A. Shashukov and A. A. Kozlov, Sov. Radiochem. (Engl. Transl.), 12: 215 (1970).

208. I. V. Shilin and T. A. Rumyantseva, Sov. Radiochem. (Engl. Transl.), 15:519 (1973).

209. N. N. Krot, M. P. Medfod'eva, T. V. Smirnova, and A. D. Gel'man, Sov. Radiochem. (Engl. Transl.), 9: 436 (1967).

210. N. N. Krot and L. G. Shuiskaya, Sov. Radiochem. (Engl. Transl.), 13: 73 (1971).

211. N. K. Shastri, J. O. Wear, and E. S. Amis, J. Inorg. Nucl. Chem., 24: 535 (1962).

212. A. A. Chaikhorskii, Sov. Radiochem. (Engl. Transl.), 12: 767 (1970).

213. N. K. Shastri and E. S. Amis, Inorg. Chem., 8: 2484 (1969).

214. N. K. Shastri and E. S. Amis, Inorg. Chem., 8: 2487 (1969).

215. V. S. Koltunov and M. F. Tikhonov, Radiokhimiya, 15: 789 (1973); see Chem. Abstr., 80: 64265z (1974).

216. E. Deutsch, J. C. Sullivan, and K. O. Watkins, submitted 1974.

217. V. P. Shilov and N. N. Krot, Sov. Radiochem. (Engl. Transl.), 11: 391 (1969). 
218. T. W. Newton and coworkers, unpublished observation, or preliminary result, Los Alamos Scientific Laboratory.

219a. A. S. Ghosh Mazumdar and K. P. R. Pisharody, J. Inorg. Nucl. Chem., 26: 1903 (1964).

219b. A. S. Ghosh Mazumdar, B. L. Gupta, and P. R. Natarajan, Catalytic Effect of Some Ions on the Rate of the Reaction Between Plutonium(II) and Chlorine in Chloride Solutions, Indian Report AEET-275, 1967.

219c. A. S. Ghosh Mazumdar and B. L. Gupta, Kinetics of the Reaction Between Plutonium(III) and Chlorine in Sulphate Solutions, Indian Report BARC-379, 1968.

220a. E. K. Dukes, J. Amer. Chem. Soc., 82: 9 (1960).

220b. V. S. Koltunov and V. I. Marshenko, Radiokhimiya, 15: 777, 781 (1973); see Chem. Abstr., 80: 64267b, 64268c (1974).

221. T. W. Newton and F. B. Baker, J. Phys. Chem., 60: 1417 (1956); also 61: 381 (1957).

222. R. E. Connick, J. Amer. Chem. Soc., 71: 1528 (1949).

223. M. Alei, Jr., Q. C. Johnson, H. D. Cowan, and J. F. Lemons, J. Inorg. Nucl. Chem., 29: 2327 (1967).

224. V. C. Koltunov and G. I. Zhuravleva, Sov. Radiochem. (Engl. Transl.), 15: 67 (1973).

225. H. Vogg, Oxidation of Plutonium(IV) to Plutonium(VI) Using Manganese Dioxide, USAEC Report EURFNR-417, March 1967, translation of German Report KFK-621.

226. V. E. Vyatkin, Y. P. Davidov, and E. A. Shashukov, Sov. Radiochem. (Engl. Transl.), 14: 299 (1972).

227. A. G. Rykov, G. A. Timofeev, G. N. Yakovlev, and V. M. Chistyakov, Sov. Radiochem. (Engl. Transl.), 11:408 (1969).

228. F. W. Tober and E. R. Russell, Concentration of Plutonium by Cation Exchange-Stabilization of Pu(III) in Nitric Acid, USAEC Report DP-349, Du Pont de Nemours (E. I.) and Co., February 1959.

229. R. E. Connick and W. H. McVey, Hydrogen Reduction of Plutonium(IV) to Plutonium(III) in Aqueous Solution, in The Transuranium Elements, Chap. 3.4, pp. 142-146, Division IV, Vol. 14B, National Nuclear Energy Series, McGraw-Hill Book Company, New York, 1949.

230. C. L. Rao and K. Neelakantan, Radiochim. Acta, 5: 48 (1966).

231. A. Ekstrom and A. McLaren, J. Inorg. Nucl. Chem., 34: 1009 (1972).

232. A. S. G. Mazumdar, P. R. Natarajan, and S. Vaidyanathan, J. Inorg. Nucl. Chem., 32: 3363 (1970).

233. G. S. Barney, Kinetics and Mechanisms of Plutonium(IV) Reduction by Hydroxylamine, USAEC Report ARH-SA-100, Atlantic Richfield Hanford Co., August 1971; and Hydroxylamine Nitrate Reduction of Plutonium(IV): Iron Catalysis, USAEC Report ARH-1920, Atlantic Richfield Hanford Co., January 1971.

234. F. L. Moore and J. E. Hudgens, Jr., Anal. Chem., 29: 1767 (1957).

235a. S. W. Rabideau, J. Amer. Chem. Soc, 75: 798 (1953).

235b. S. W. Rabideau, L. B. Asprey, T. K. Keenan, and T. W. Newton, Recent Advances in the Basic Chemistry of Plutonium, Americium, and Curium, in Proceedings of the Second United Nations International Conference on the Peaceful Uses of Atomic Energy, Geneva, 1958, Vol. 28, pp. 361-372, United Nations, New York, 1958.

236. P. I. Artyukhin, V. I. Medvedovskii, and A. D. Gel'man, Russ. J. Inorg. Chem. (Engl. Transl.), 4: 596 (1959).

237. N. P. Ermolaev, N. N. Krot, and A. D. Gel'man, Sov. Radiochem. (Engl. Transl.), 9: 169 (1967).

238. A. S. Ghosh Mazumdar, S. C. Khandelwal, and P. R. Natarajan, J. Inorg. Nucl. Chem., 30: 3295 (1968).

239. O. L. Kabanova, M. A. Danuschenkova, and P. N. Paley, Anal. Chim. Acta, 22: 66 (1960).

240. F. A. Zakharova, M. M. Orlova, and N. N. Krot, Radiokhimiya, 15: 786 (1973); see Chem. Abstr., 80: 64266a (1974).

241a. V. S. Koltunov and G. I. Zhuravleva, Sov. Radiochem. (Engl. Transl.), 10: 648 (1968). 
241b. C. A. Colvin, Reduction of Plutonium(VI) to Plutonium(V), (IV), and (III) by Nitrite in a Nitrate System, USAEC Report ARH-SA-12, Atlantic Richfield Hanford Co., May 31, 1968.

242. Y. A. Komov, N. N. Krot, and A. D. Gel'man, Sov. Radiochem. (Engl. Transl.), 12: 656 (1970).

243. Y. A. Komkov and N. N. Krot, Sov. Radiochem. (Engl. Transl.), 12: 206 (1970). 


\section{INDEX}

Absorptivities, of actinide ions in acid solutions, 6

Acetate ion, reaction with $\mathrm{Pu}(\mathrm{VII}), 117$

Activated complex, 8 composition of, from rate law, 9

Activation process, 8

Alpha particle irradiation, effects of on americium solutions, 59-60

on cerium solutions, 56

on $\mathrm{Np}(\mathrm{VI})$ solutions, 56

on plutonium solutions, 55.57

on water, 55

Ascorbic acid, reaction of

with Pu(IV), 112

with Pu(VII), 116

Binuclear intermediates, kinetic evidence for, $29,31,33-34$

Bismuth(V), reaction with $\mathrm{Pu}(\mathrm{IV}), 110$

Bromate ion, reaction of

with $\mathrm{Np}(\mathrm{V}), 101$

with $\mathrm{Pu}(\mathrm{III}), 108$

with $\mathrm{Pu}(\mathrm{IV}), 110$

with U(IV), 78, 94

Bromine, reaction of

with $\mathrm{Pu}(\mathrm{IV}), 110$

with U(IV), 94
Catalysis, by uranium(VI), 24, 25

Cerium(IV), reaction of

with $\mathrm{Np}(\mathrm{V}), 76,101$

with Pu(III), 108

with Pu(IV), 110

with $\mathrm{Pu}(\mathrm{V}), 111$

with U(IV), 74, 94

Chemical formulas, of actinide ion in acid solutions, 3

Chlorate ion, reaction with U(IV), 94

Chloride ion

effect on alpha reduction of plutonium, 57 reaction with $\mathrm{Np}(\mathrm{VI}), 105$

Chlorine, reaction of with Pu(III), 108

with $\mathrm{Pu}(\mathrm{IV}), 110$

with $\mathrm{Np}$ (IV), 100

Chlorous acid, reaction with U(IV), $38,79,94$

Chromium(II), reaction of with $\mathrm{Np}$ (IV), 73, 103

with $N p(V), 34,75,103$

with Pu(VI), 115

with U(V)-Cr(III) complex, 75, 97

with U(VI), 76, 98 


\section{Chromium(III)}

aquo, reaction with U(III), 93

complexes of, reaction of with U(III), 93

with Pu(III), 75, 108

Chromium(VI), reaction of

with $\mathrm{Np}(\mathrm{IV}), 42$

with $\mathrm{Np}(\mathrm{V}), 79,101$

with $\mathrm{Pu}(\mathrm{III}), 108$

with $\mathrm{Pu}(\mathrm{IV}), 42,110$

with $\mathrm{Pu}(\mathrm{V}), 111$

with U(IV), 42, 79, 95

Citrate ion, reaction with Np(VIII), 106

Cobalt(III)

aquo, reaction of

with $\mathrm{Np}(\mathrm{V}), 19,76,101$

with $\mathrm{Np}(\mathrm{V})-\mathrm{Cr}$ (III) complex, 21, 76

complexes of, reaction of

with $\mathrm{Np}$ (III), 99

with $\mathrm{Pu}(\mathrm{IV}), 110$

with U(III), 13, 73, 92

Debye-Hückel equation, applied to activation processes, 67

Diffusion-controlled limit, applied to the $\mathrm{Np}$ (VI) $-\mathrm{H}_{2} \mathrm{O}_{2}$ reaction, 29

Diffusion-controlled reactions, effect of charge, 13

Disproportionation

of actinide(V) ions compared, 66

of $\mathrm{Am}(\mathrm{V}), 63,75,118$

of $\mathrm{Pu}(\mathrm{IV}), 113$

of $\mathrm{Pu}(\mathrm{V}), 46,75,114$

of U(V), 75, 97

Driving force $(\Delta G)$

See also Free energy

effect on

$\mathrm{H}^{+}$dependence, 47

$\Delta S^{*}, 51$

Enthalpy

of activation (see Heat of activation)

of oxidation of actinide ions in acid solutions, 4

Entropy

of activated complexes, correlation with

charge, 86

of activation, 8

correlation with $\Delta \mathrm{n}$ and $\Delta \mathrm{z}^{2}, 84-85$

ionic, of actinide ions in acid solutions, 5

of oxidation of actinide ions in acid solutions, 4
Ethanol, reaction with Np(VII), 106

Ethylenediaminetetraacetic acid (EDTA), reaction of

with Np(VI), 105

with $\mathrm{Np}$ (VII), 107

with Pu(VI), 115

Europium(II), reaction with U(VI), 76, 98

Eyring equation, 8

Ferric ion, reaction of with $\mathrm{Np}$ (III), 72, 99

with $\mathrm{Np}(\mathrm{IV}), 74,100$

with U(IV), 16, 74, 94

with U(V), 97

Ferricyanide ion, reaction of

with $\mathrm{Np}(\mathrm{VI}), 102$

with U(IV), 79, 94

Ferrocyanide ion, reaction with $\mathrm{Pu}$ (VII), 116

Ferrous ion, reaction of

with $\mathrm{Np}(\mathrm{V}), 103$

with $\mathrm{Np}$ (VI), 105

with $\mathrm{Pu}(\mathrm{IV}), 73,112$

with $\mathrm{Pu}(\mathrm{V}), 114$

with $\mathrm{Pu}$ (VI), 32, 76, 115

with U(VI), 98

Formaldehyde, reaction of

with $\mathrm{Np}$ (VII), 107

with Pu(VII), 117

Formate ion, reaction of

with $\mathrm{Np}(\mathrm{VII}), 107$

with Pu(VII), 116

Formic acid, reaction with $\mathrm{Np}$ (VII), 77, 107

Free energy

of activation, 8

correlation with $\Delta H$ and $\Delta n, 88-89$

of oxidation of actinide ions in acid solutions, 4

Harned's rule, applied to medium effects, 11

Heat of activation, 8

correlation with $\Delta \mathrm{H}$ and hydrogen-ion dependence, 86-88

Hydrazine, reaction of with $\mathrm{Np}(\mathrm{V}), 104$

with $\mathrm{Np}$ (VI), 77, 105

with $\mathrm{Pu}(\mathrm{IV}), 113$

with $\mathrm{Pu}(\mathrm{V}), 114$

with $\mathrm{Pu}$ (VI), 77, 115

with Pu(VII), 116 
Hydrogen, reaction with $\mathrm{Pu}($ IV), 112

Hydrogen peroxide

radiolytic yield, 55

reaction of

with $\mathrm{Am}(\mathrm{V}), 60,119$

with Am(VI), 61, 119

with $\mathrm{Np}$ (III), 99

with $\mathrm{Np}(\mathrm{V}), 104$

with $\mathrm{Np}$ (VI), 27, 79, 105

with $\mathrm{Pu}(\mathrm{III}), 108$

with $\mathrm{Pu}(\mathrm{IV}), 112$

with $\mathrm{Pu}(\mathrm{V}), 114$

with $\mathrm{Pu}(\mathrm{VI}), 29,79$

with $\mathrm{Pu}$ (VII), 116

with U(IV), 95

steady-state concentration in

$239 \mathrm{Pu}$ solutions, 56

${ }^{241}$ Am solutions, 61

Hydrogen sulfide, reaction with $\mathrm{Pu}(\mathrm{IV})$, 112

Hy droly sis

of activated complexes, $82-83$

effect on rate law, 15

relative tendency, for actinide ions, 7

Hy droquinone, reaction of

with $\mathrm{Np}$ (VI), 79, 105

with $\mathrm{Pu}(\mathrm{IV}), 79,112$

with $\mathrm{Pu}$ (VI), 79, 115

Hydroxylamine, reaction of

with $\mathrm{Np}(\mathrm{V}), 104$

with $\mathrm{Np}$ (VI), 105

with Pu(IV), 113

with $\mathrm{Pu}(\mathrm{V}), 114$

with $\mathrm{Pu}(\mathrm{VI}), 115$

with Pu(VII), 116

Hy pobromite ion, reaction with $\mathrm{Np}$ (VI), 102

Hypochlorous acid, reaction with $\mathrm{Pu}(\mathrm{IV})$, 110

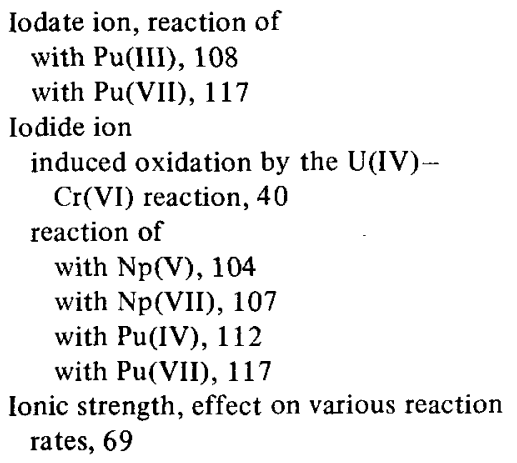

Lead tetraacetate, reaction with $\mathrm{Pu}(\mathrm{IV}), 111$

Manganese(III), reaction with Pu(IV), 111

Manganese dioxide, reaction with $\mathrm{Pu}(\mathrm{IV}), 111$

Marcus equation, 12

applied to sets of similar reactions, 51

Mechanism, general, for aqueous oxidationreduction reactions, 7

Mercurous ion, reaction of

with Np(VII), 25, 77, 107

with other ions, 25

Methanol, reaction with $\mathrm{Pu}(\mathrm{VII}), 117$

Net activation process, 9

for various reactions, 72-79

Nitrate ion, reaction of

with $\mathrm{Np}(\mathrm{V}), 101$

with $\mathrm{Pu}(\mathrm{III}), 109$

with Pu(IV), 111

Nitrite ion, reaction with $\mathrm{Np}$ (VII), 107

Nitrous acid, reaction of

with Np(VI), 105

with Pu(II), 109

with Pu(V), 114

with Pu(VI), 115

with U(IV), 95

Oxalate ions, reaction of with Np(VII), 106

with Pu(VII), 117

Oxalic acid, reaction of

with $\mathrm{Np}(\mathrm{V}), 103$

with $\mathrm{Np}$ (VI), 105

with Pu(VI), 115

Oxygen, reaction of

with $N p(I I I), 99$

with Np(IV), 100

with Pu(III), 109

with U(IV), 95

Oxygen tracer

applied to reactions of

Cr(II)-Np(V), 37

U(IV)-Cl(III), 40

U(IV)-Cr(VI), 43

Ozone, reaction of

with $\mathrm{Np}(\mathrm{VI}), 102$

with Pu(IV), 111

Pattern of paths, 9

electrical analogs for, 10

Perchlorate ion, reaction with U(III), 92

Perchloric acid, reaction with $\mathrm{Pu}(\mathrm{IV}), 110$

Periodic acid, reaction with $\mathrm{Pu}(\mathrm{IV}), 110$ 
Permanganate ion, reaction of

with $\mathrm{Np}($ IV), 100

with $\mathrm{Np}(\mathrm{V}), 101$

with Pu(III), 108

with $\mathrm{Pu}(\mathrm{IV}), 75,110$

Peroxydisulfate ion

reaction of

with Am(III), 61, 118

with $\operatorname{Am}(V), 62,118$

with Np(VI), 102

with $\mathrm{Pu}(\mathrm{IV}), 111$

with U(IV), 96

thermal decomposition of, 62

Phenol, as a scavenger in the $\mathrm{U}$ (IV)- $\mathrm{Cl}$ (III) reaction, 38

Potential, reduction, for actinide ions in acid solutions, 4

Radioly tic steady state, in plutonium solutions, 56

Radiolytic yields, 55-57, 60

Rate law, 8

effect of medium on, 11

empirical, 15

Reaction medium

effect on oxidation potentials, 11

and rate laws, 11

Reduction potential, for actinide ions in acid solutions, 4

Ruthenium(III) complexes, reaction with $\mathrm{Np}($ III), 73, 96

Silver(I), reaction of with $\mathrm{Np}$ (VII), 106 with Pu(IV), 110

Silver(II), reaction of

with Np(IV), 100

with Pu(IV), 110

Silver metal, reaction with Pu(IV), 112

Simultaneous rate equations, 36,45

Stannous ion, reaction of

with $N p(V), 104$

with Np(VI), 106

with Pu(IV), 78, 113

with $\mathrm{Pu}(\mathrm{V}), 114$

with Pu(VI), 78, 116

with Pu(VII), 116

with U(VI), 98

Steady state, radioly tic, in plutonium solutions, 56

Steady-state approximation, 9 applied to reactions of $\mathrm{Np}(\mathrm{V})-\mathrm{V}(\mathrm{III}), 23$
$\mathrm{Np}(\mathrm{VI})-\mathrm{H}_{2} \mathrm{O}_{2}, 28$

U(IV)-Cl(III), 39

U(IV)-Pu(VI), 30

Stoichiometry, change during reaction, 46

Sulfite ion, reaction of

with Np(VII), 107

with Pu(VII), 116

Sulfur dioxide, reaction of

with $\mathrm{Np}(\mathrm{V}), 104$

with Pu(IV), 113

with $\mathrm{Pu}(\mathrm{V}), 114$

Thallium(I), reaction with $\mathrm{Np}$ (VII), 27, 77, 107

Thallium(III), reaction of

with $\mathrm{Pu}(\mathrm{III}), 109$

with U(IV), 74, 96

Thiosulfate ion, reaction of

with $\mathrm{Np}$ (VII), 107

with Pu(VII), 117

Titanium(II), reaction of

with $\mathrm{Pu}(\mathrm{IV}), 73,113$

with $\mathrm{Pu}(\mathrm{V}), 114$

with $\mathrm{Pu}(\mathrm{VI}), 77,116$

with U(VI), 98

Vanadium(II), reaction of

with $\mathrm{Np}$ (IV), 73, 103

with U(VI), 23, 76, 98

Vanadium(III), reaction of with $\mathrm{Np}(\mathrm{V}), 22,75,104$

with $\mathrm{Np}$ (VI), 77, 106

with $\mathrm{Pu}(\mathrm{IV}), 14,73,113$

with $\mathrm{Pu}(\mathrm{V}), 114$

with $\mathrm{Pu}(\mathrm{VI}), 77$

with U(VI), 77, 98

Vanadium(IV), reaction of with $\mathrm{Np}$ (VI), 105

with $\mathrm{Np}$ (VII), 77, 107

Vanadium(V), reaction of

with $N p(V), 102$

with $\mathrm{Pu}(\mathrm{IV}), 111$

Water, reaction of

with $\mathrm{Np}$ (VII), 107

with Pu(VII), 117

with U(III), 93

Xenon trioxide, reaction of

with $\mathrm{Np}(\mathrm{V}), 102$

with Pu(III), 79, 109 


\section{NOTICE}

This book was prepared as an account of work sponsored by the United States Government. Neither the United States nor the United States Energy Research and Development Administration, nor any of their employees, nor any of their contractors, subcontractors, or their employees, makes any warranty, express or implied, or assumes any legal liability or responsibility for the accuracy, completeness or usefulness of any information, apparatus, product or process disclosed, or represents that its use would not infringe privately owned rights. 
